Universidad Politécnica de Madrid

Escuela Técnica Superior de Arquitectura de Madrid

\title{
LA CONECTIVIDAD ECOLÓGICA EN LOS PAISAJES DE MANGLARES DE LA REGIÓN METROPOLITANA DE FLORIANÓPOLIS, COSTA SUR DE BRASIL
}

\author{
Tesis Doctoral \\ Bárbara Heliodora Alves d’Acampora
}

Arquitecta

Madrid, 2018 

Departamento de Urbanística y Ordenación del Territorio

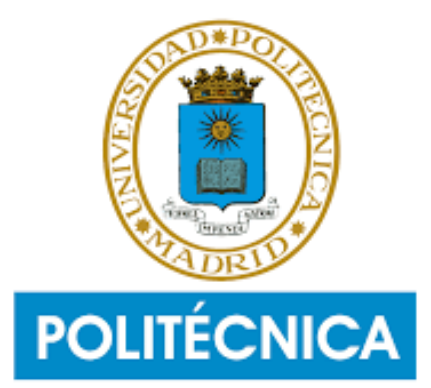

Escuela Técnica Superior de Arquitectura de Madrid

\title{
LA CONECTIVIDAD ECOLÓGICA EN LOS PAISAJES DE MANGLARES DE LA REGIÓN METROPOLITANA DE FLORIANÓPOLIS, COSTA SUR DE BRASIL
}

\author{
Tesis Doctoral
}

Bárbara Heliodora Alves d'Acampora

Arquitecta

Directoras

Ester Higueras García

Emilia Román López

Departamento de Urbanística y Ordenación del Territorio, ETSAM

Madrid, 2018 

Tribunal nombrado por el Magfco. y Excmo. Sr. Rector de la Universidad Politécnica de Madrid, el día de de 2018.

Presidente

Vocal

Vocal

Vocal

Secretario

Suplente

Suplente

Realizado el acto de defensa y lectura de la Tesis el día de de 2018 en la E.T.S. Arquitectura.

CALIFICACIÒN:

EL PRESIDENTE

LOS VOCALES

EL SECRETARIO 
A mi marido Cleiton Taufemback por el apoyo e incentivo a lo largo de este trayecto. 


\section{AGRADECIMIENTOS}

Agradezco a la dirección de Ester Higueras y Emilia Román por toda la dedicación y la confianza en mi trabajo.

A Cleiton Taufemback por la orientación matemática para el desarrollo de la investigación.

Y al programa de becas CNPq (Conselho Nacional de Desenvolvimento Científico e Tecnológico) de Brasil por haber financiado mis estudios en Madrid. 


\section{RESUMEN}

Los manglares son una tipología de ecosistema natural de estructura arbórea o arbustiva y densa que se sitúan en la transición del medio terrestre y marino, en ambientes de clima cálido y húmedo, en las zonas tropicales y también subtropicales. Su desarrollo está condicionado por los factores físicos en que viven y proporcionan distintos servicios ecosistémicos de regulación, abastecimiento y culturales.

Sin embargo, se han ocasionado grandes pérdidas ambientales por las actividades humanas en el nivel mundial y nacional (Brasil). En el caso de estudio de la Región Metropolitana de Florianópolis, los manglares se encuentran degradados por los procesos del uso del suelo a lo largo de la historia, con débil control ambiental y planeamiento inadecuado de protección ambiental.

Debido a esto, el objetivo principal que esta investigación propone realizar es un estudio sobre la existencia, beneficios y mantenimiento de la conectividad ecológica en los paisajes de manglares de la Región Metropolitana de Florianópolis. A partir de la caracterización espacial de los nueve paisajes de manglares existentes, se observó una discontinuidad de los espacios naturales debido a la perdida y fragmentación de los manglares, verificando los paisajes menos y más afectados por la ocupación humana.

Finalmente, a través de la evaluación de la conectividad ecológica en los paisajes de manglares menos y más afectados, se identificaron y analizaron estructural y funcionalmente los fragmentos de hábitats más críticos, relacionándolos con las figuras de protección ambiental vigentes para el mantenimiento de la conectividad ecológica y la conservación de los servicios ecosistémicos de los manglares. 


\section{ABSTRACT}

The mangroves are a type of natural ecosystem of arboreal or shrub and dense structure that are situated in the transition from the terrestrial and marine environment, in environments of warm and humid climate, in the tropical and also subtropical zones. Their development is conditioned by the physical factors in which they live and provide different ecosystem services of regulation, supply, and cultural.

However, great environmental losses have been caused by human activities at the global and national levels (Brazil). In the case of the study of the Metropolitan Region of Florianópolis, mangroves are degraded by the processes of land use throughout history, with weak environmental control and inadequate planning of environmental protection.

Due to this, the main objective that this research proposes to carry out is a study of the existence, benefits, and maintenance of ecological connectivity in the mangrove landscapes of the Metropolitan Region of Florianópolis. From the spatial characterization of the nine landscapes of existing mangroves, a discontinuity of the natural spaces due to the loss and fragmentation of the mangroves was observed, verifying the less and more affected landscapes by the human occupation.

Finally, through the evaluation of the ecological connectivity in the landscapes of mangroves less and more affected, the fragments of the most critical habitats were identified and analyzed structurally and functionally, relating them to the environmental protection figures in force for the maintenance of ecological connectivity and the conservation of the ecosystem services of the mangroves. 


\section{ÍNDICE GENERAL}

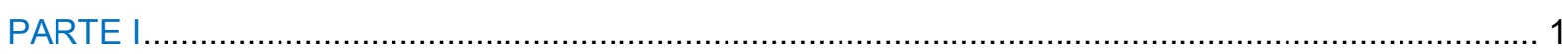

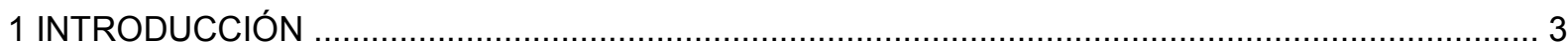

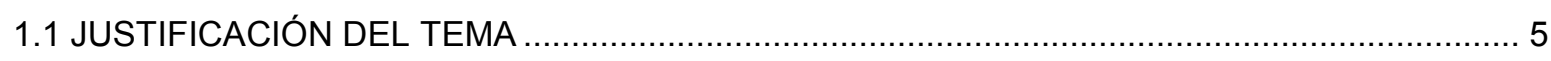

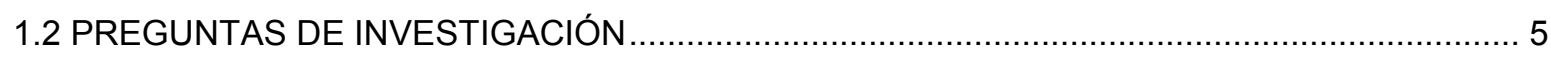

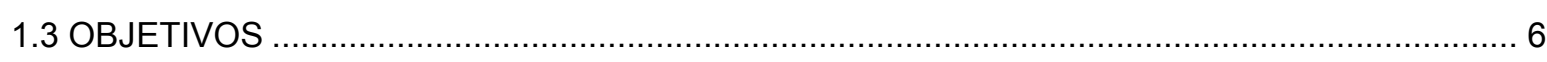

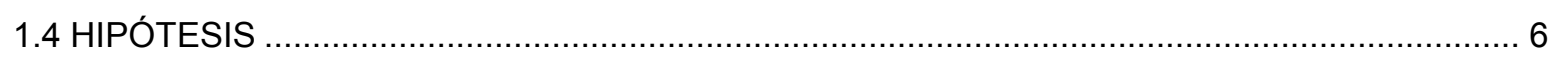

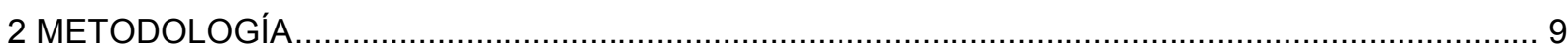

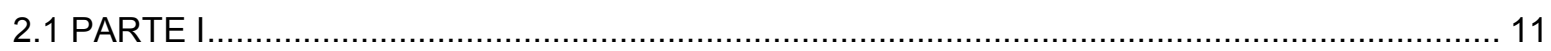

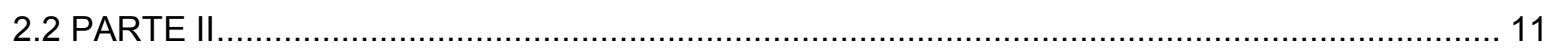

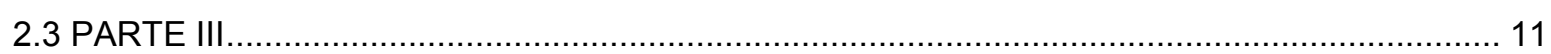

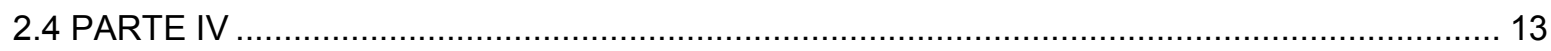

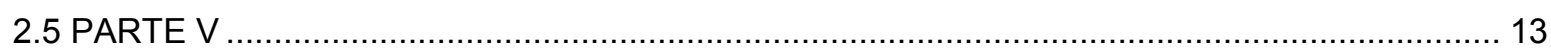

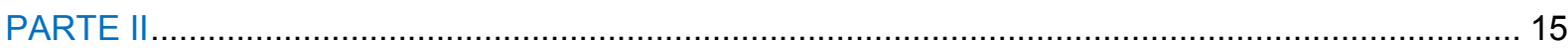

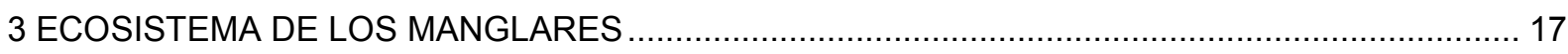

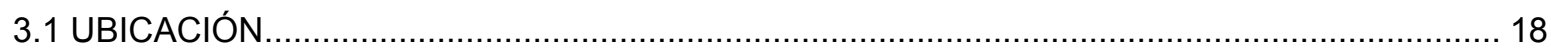

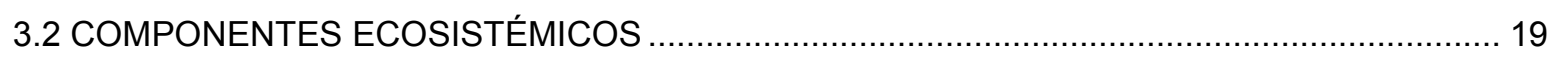

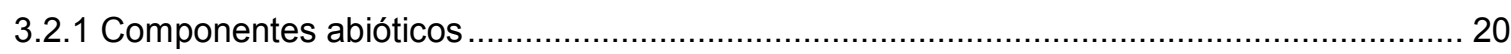

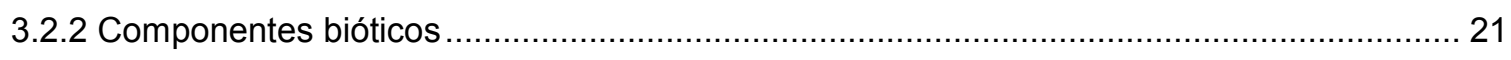

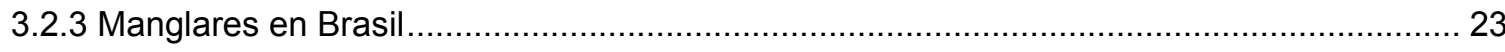

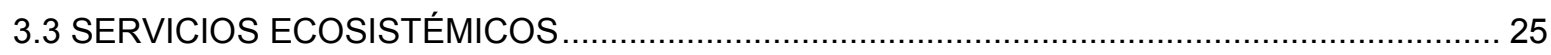

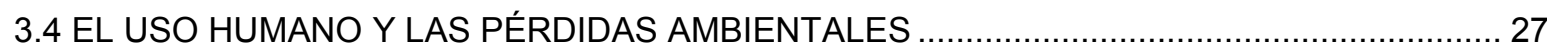

4 FIGURAS DE PROTECCIÓN LEGAL DE LOS MANGLARES ................................................... 31

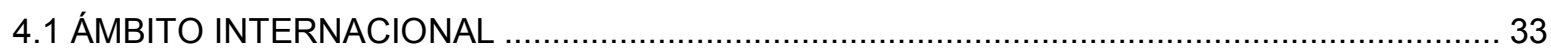

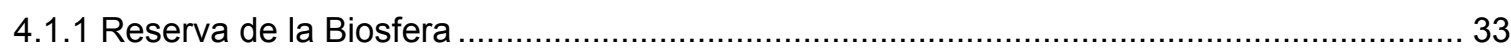

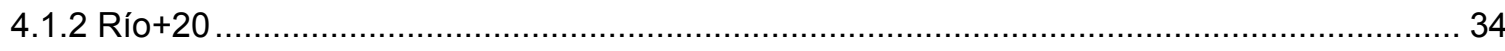

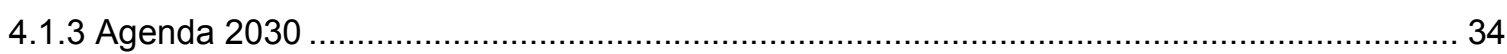

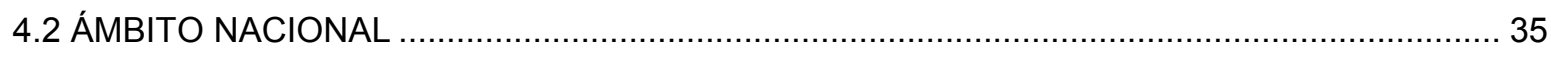

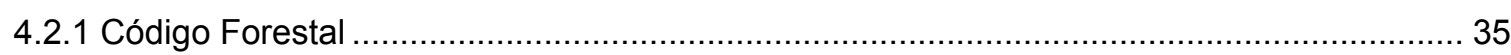

4.2.2 Constitución Federal y Plan Nacional de Gestión Costera (PNGC) ……......................... 36

4.2.3 Sistema Nacional de Unidades de Conservación (SNUC) ….............................................. 36

4.2.4 Consejo Nacional del Medio Ambiente (Conama) …….................................................... 38

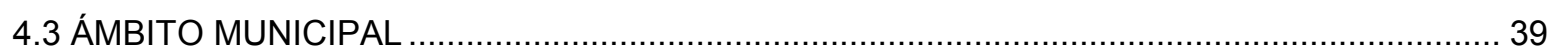

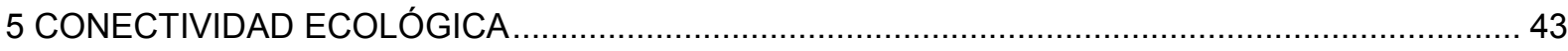

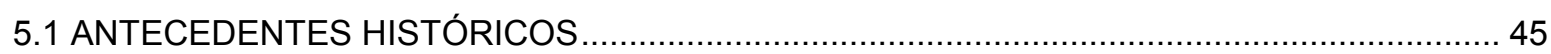

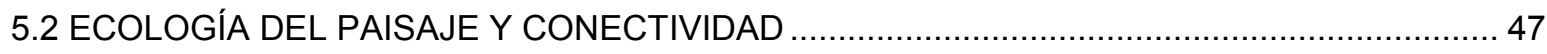

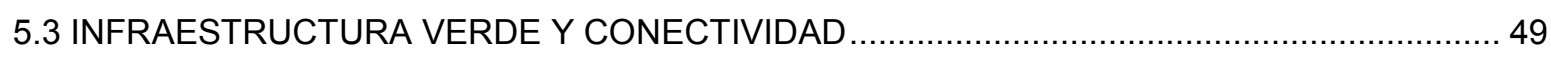

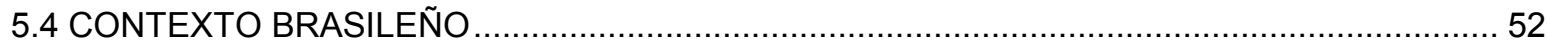

5.4.1 La relación entre los espacios naturales y urbanos ........................................................... 52 


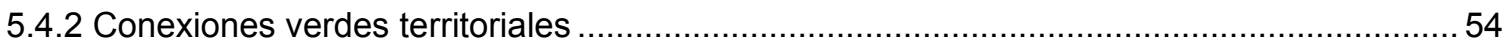

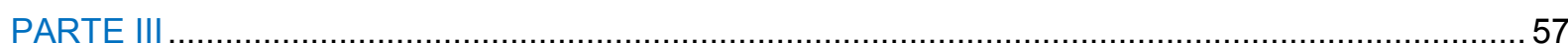

6 CARACTERIZACIÓN DE LOS PAISAJES DE MANGLARES DE LA REGIÓN METROPOLITANA

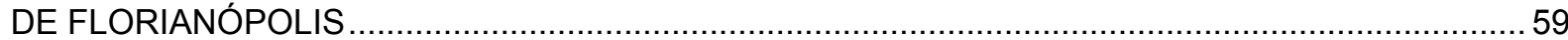

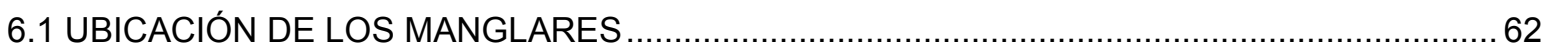

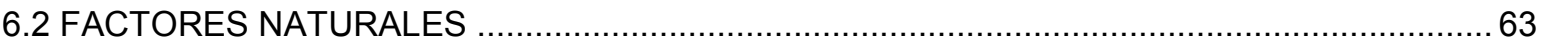

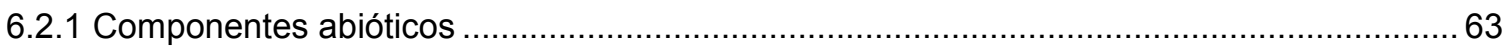

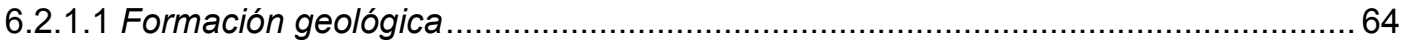

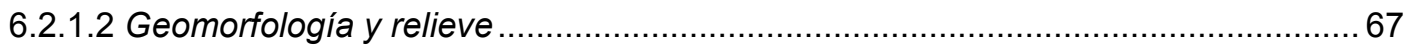

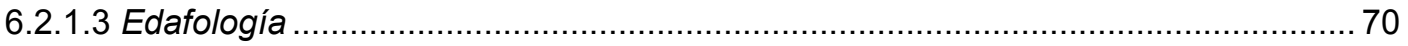

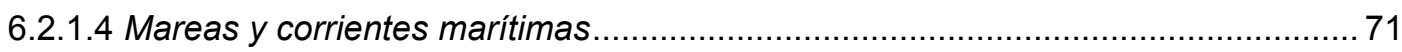

6.2.1.5 Clima, fenómenos y cambios climáticos .......................................................... 74

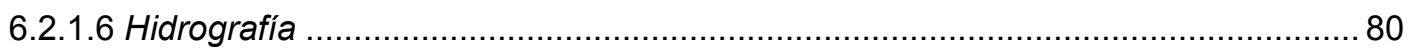

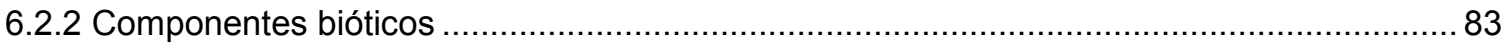

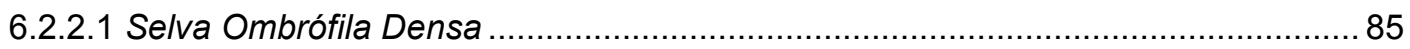

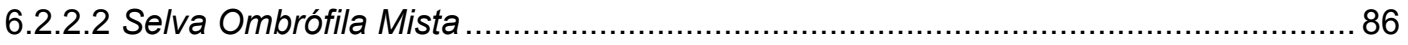

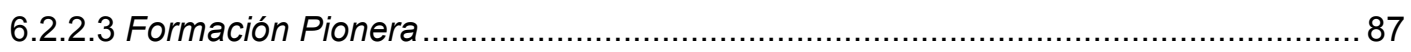

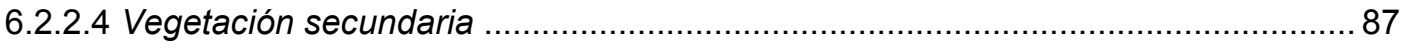

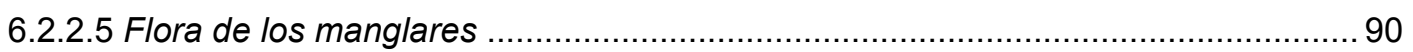

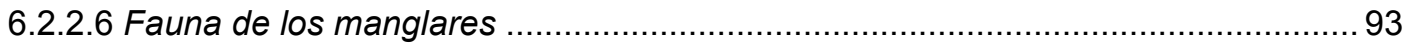

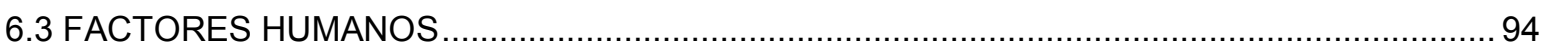

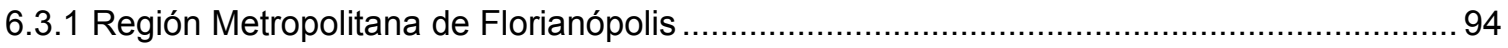

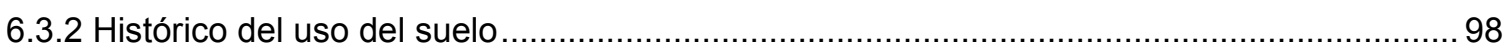

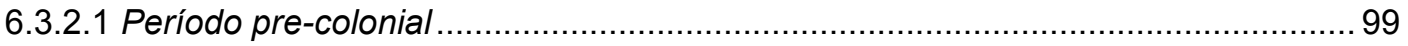

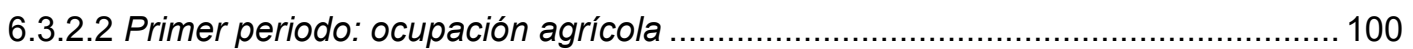

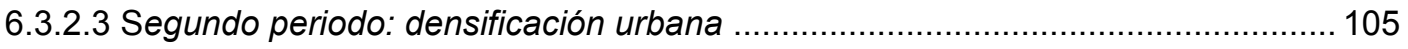

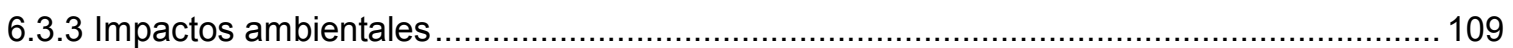

6.3.3.1 Pérdida y fragmentación de la vegetación ....................................................... 109

6.3.3.2 Plantación de especies exóticas......................................................................... 110

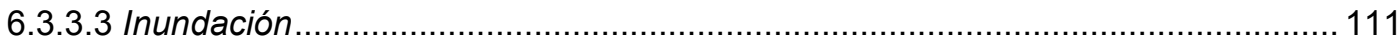

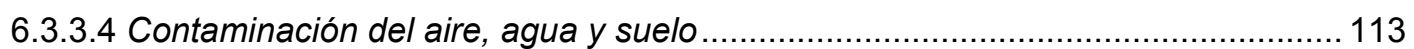

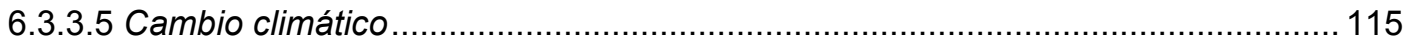

6.3.3.6 Evaluación de los impactos ambientales .............................................................. 116

6.4 CARACTERIZACIÓN ESPACIAL DE LOS PAISAJES DE MANGLARES …........................118

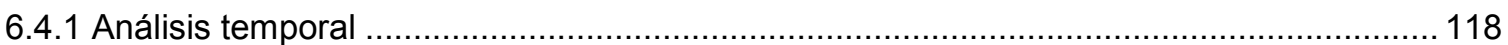

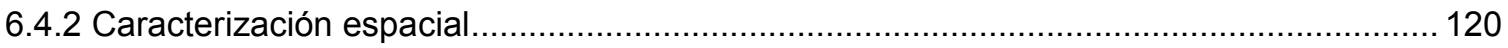

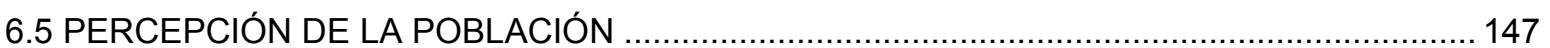

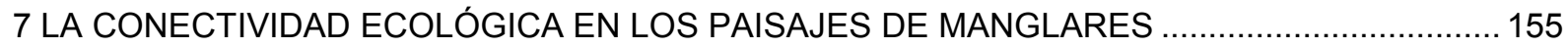

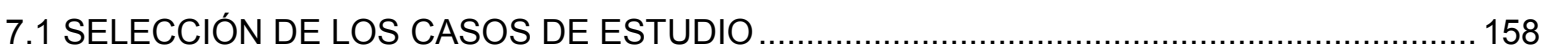

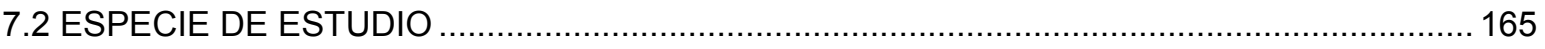

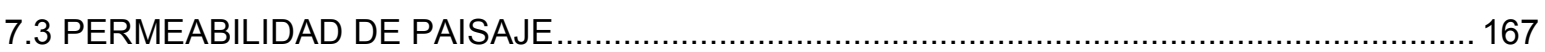




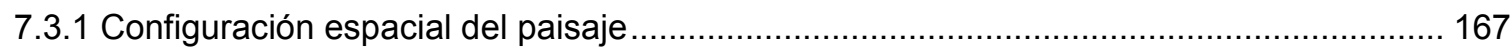

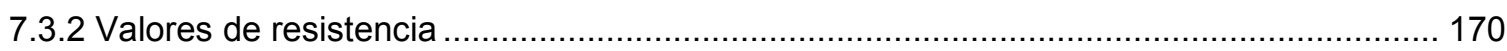

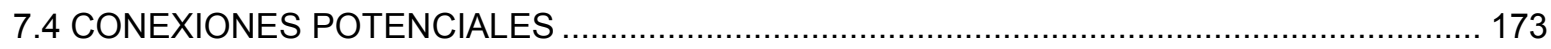

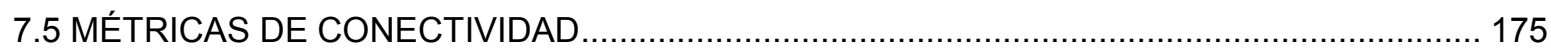

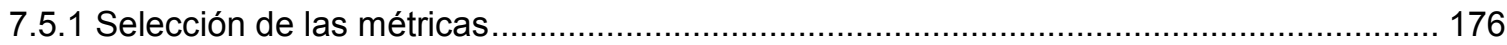

7.5.2 Valores de conectividad ecológica de cada fragmento de hábitat................................... 178

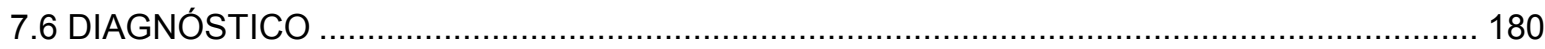

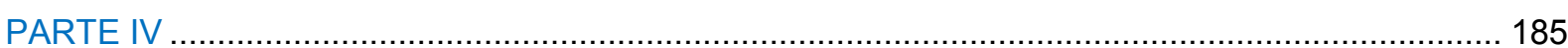

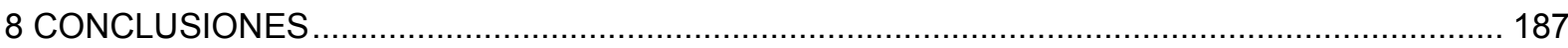

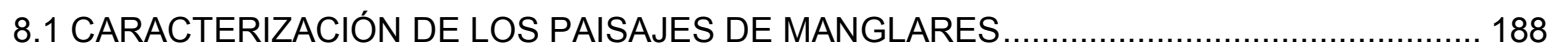

8.2 CONECTIVIDAD ECOLÓGICA EN LOS PAISAJES DE MANGLARES ................................ 191

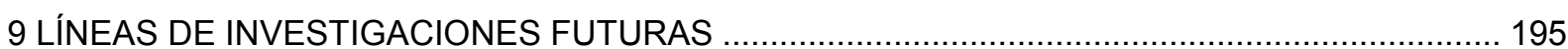

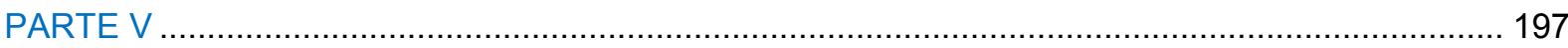

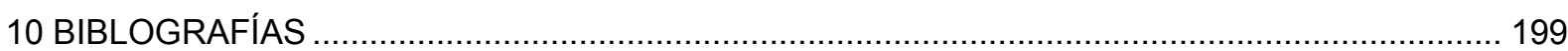

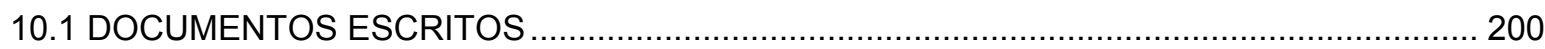

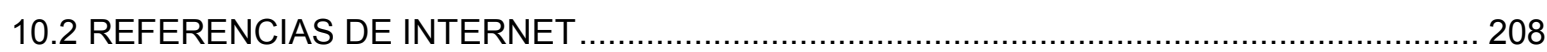

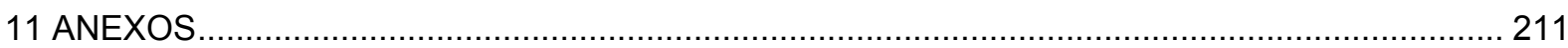

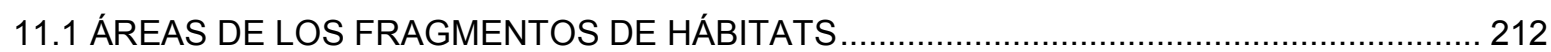

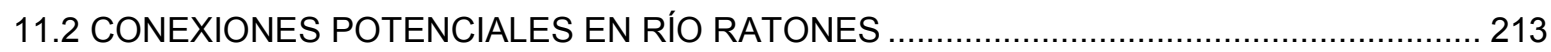

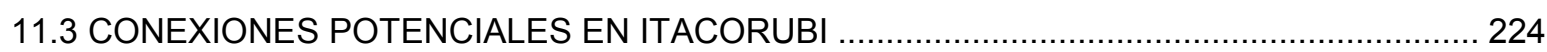

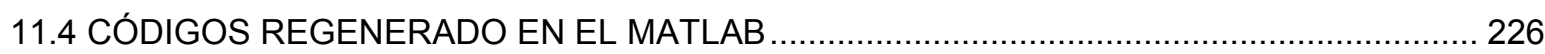

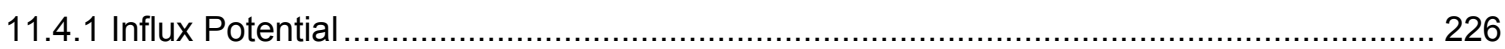

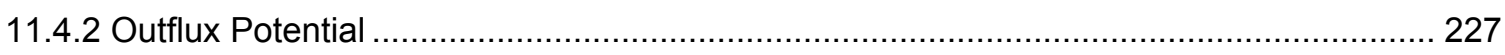

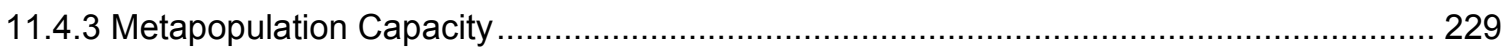

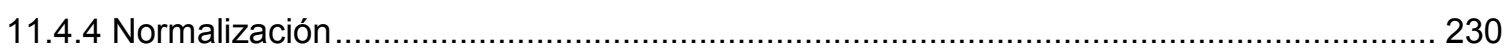

11.5 VALORES DE LOS NODOS PARA CADA MÉTRICA DE CONECTIVIDAD ECOLÓGICA EN

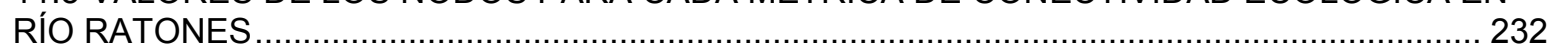

11.6 VALORES DE LOS NODOS PARA CADA MÉTRICAS DE CONECTIVIDAD ECOLÓGICA EN

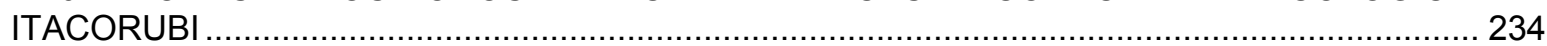

11.7 VALORES NORMALIZADOS DE LOS NODOS (ENTRE 0 Y 1) PARA CADA MÉTRICA DE

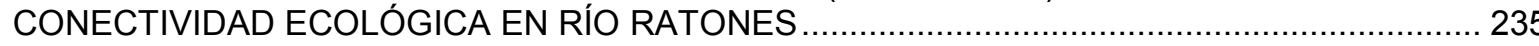

11.8 VALORES NORMALIZADOS DE LOS NODOS (ENTRE 0 Y 1) PARA CADA MÉTRICA DE

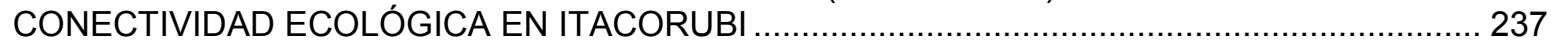

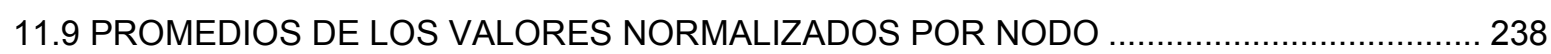

11.10 VALORES NORMALIZADOS (ENTRE 0 Y 1) DE LOS PROMEDIOS POR NODO ............. 239

11.11 ÁREAS DE PROTECCIÓN AMBIENTAL POR NODO (MÁS CRÍTICOS) DE RÍO RATONES

11.12 ÁREAS DE PROTECCIÓN AMBIENTAL POR NODO (MÁS CRÍTICOS) DE ITACORUBI 242 


\section{ÍNDICE DE FIGURAS}

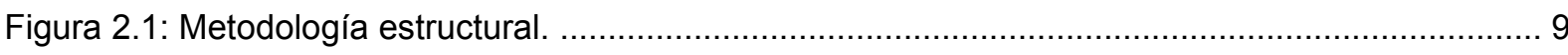

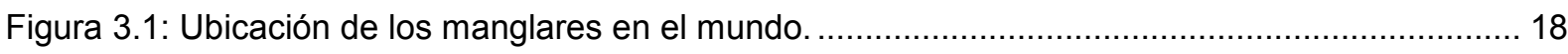

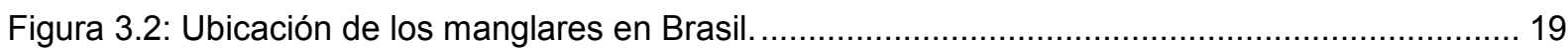

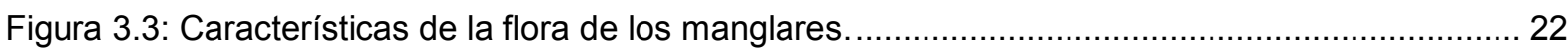

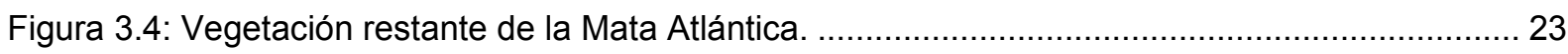

Figura 3.5: Segmentación de los manglares en la costa brasileña. ................................................ 24

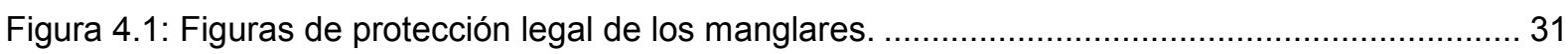

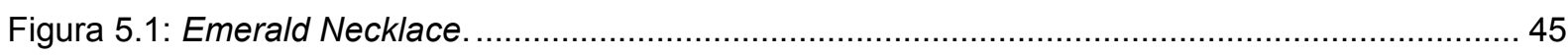

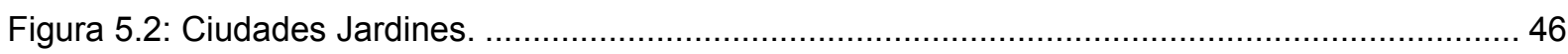

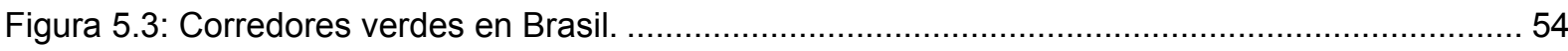

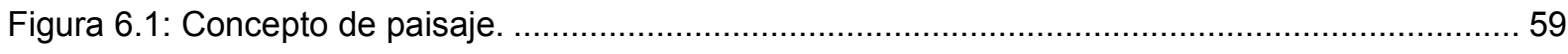

Figura 6.2: Ubicación de los manglares en la Región Metropolitana de Florianópolis. ......................... 62

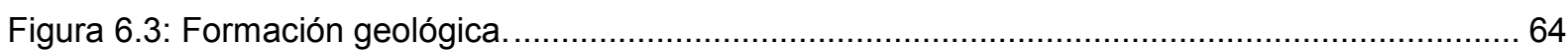

Figura 6.4: Dibujo de la comparación entre el pasado geológico (a la lzquierda) y el actual (a la derecha)

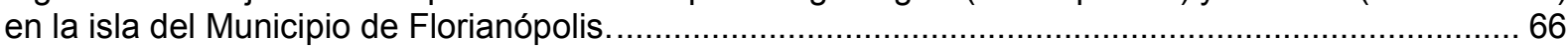

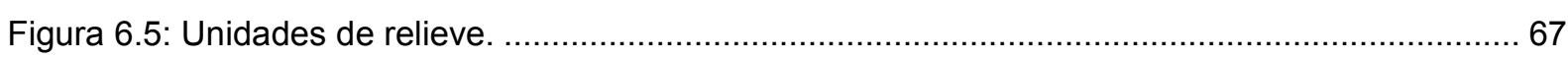

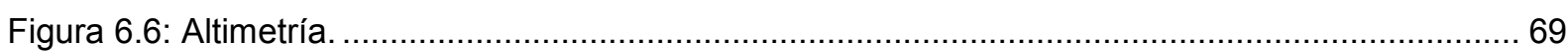

Figura 6.7: Llanura Costera (parte Norte de la Isla del Municipio de Florianópolis). Compartimentos

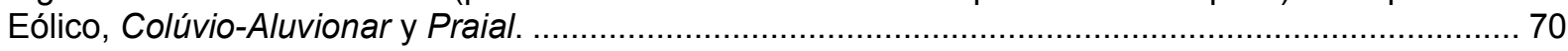

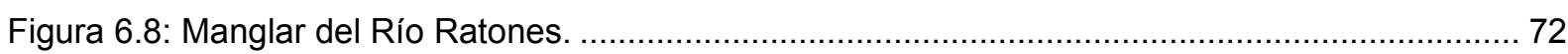

Figura 6.9: Intensidades de la corriente marítima en las Bahías Norte y Sur. .................................... 73

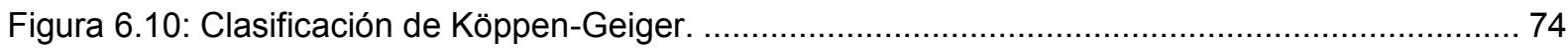

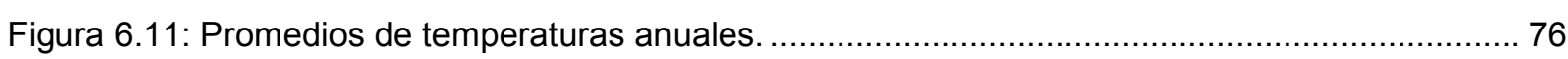

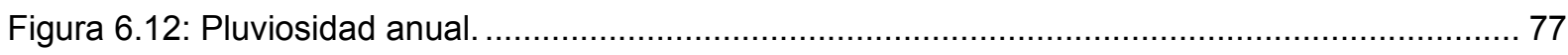

Figura 6.13: Promedios de pluviosidad y de temperatura en el Municipio de Florianópolis, entre los años

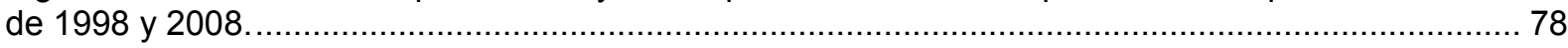

Figura 6.14: Promedios de la velocidad de los vientos en el Municipio de Florianópolis, entre los años

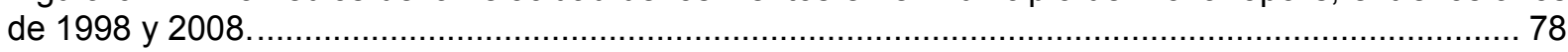

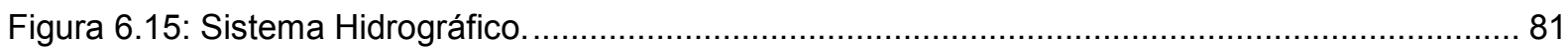

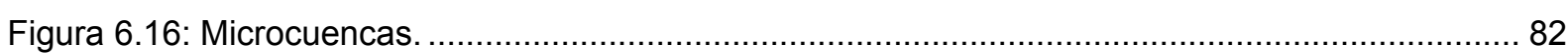

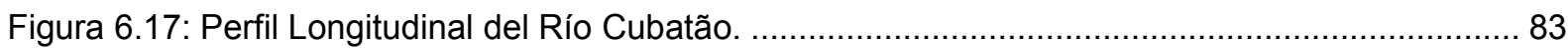

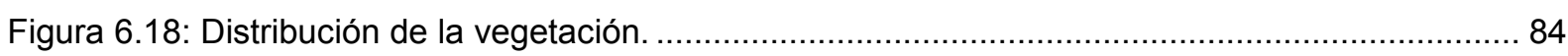

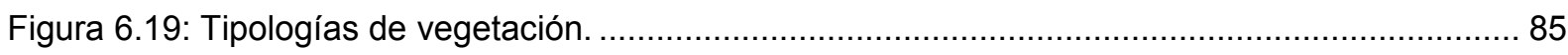

Figura 6.20: Etapas de vegetación secundaria para especies de la Selva Ombrófila Densa. ............. 88

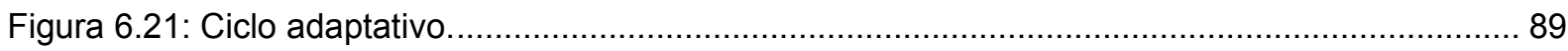




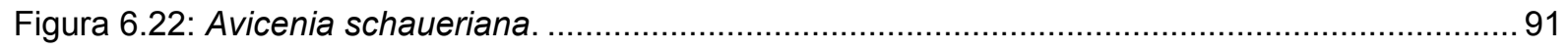

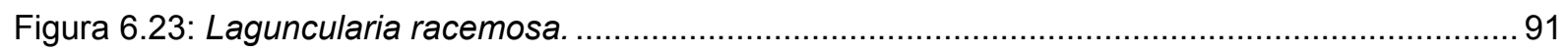

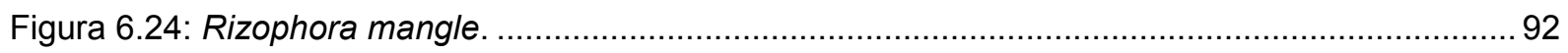

Figura 6.25: Perfil de vegetación de manglar con vegetaciones asociadas. ....................................... 93

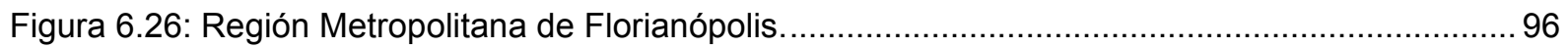

Figura 6.27: Densidad de la Región Metropolitana de Florianópolis. ................................................. 97

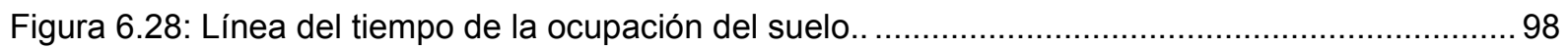

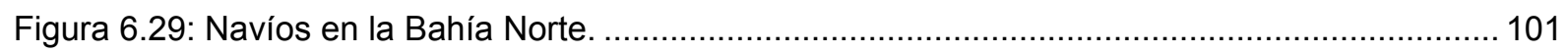

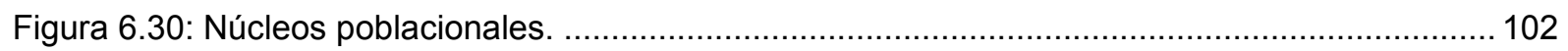

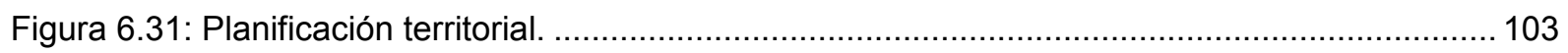

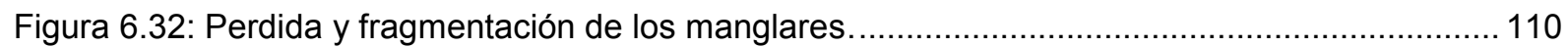

Figura 6.33: Frecuencia de inundación gradual y brusca por municipio $(1980-2010)$........................ 112

Figura 6.34: Inundación brusca en el manglar del Río Tavares................................................. 113

Figura 6.35: Residuos de basura ubicados en los manglares de Itacorubi y de Palhoça,

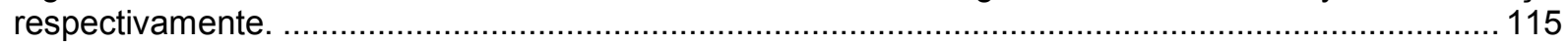

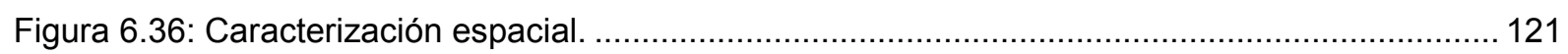

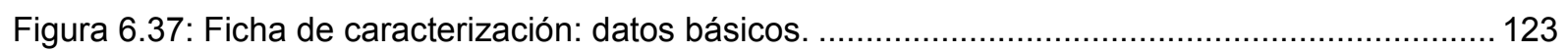

Figura 6.38: Ficha de caracterización: caracterización espacial del paisaje de manglar. ................... 125

Figura 6.39: Ficha de caracterización del manglar del Río Ratones. .............................................. 127

Figura 6.40: Ficha de caracterización del manglar de Saco Grande. .............................................. 129

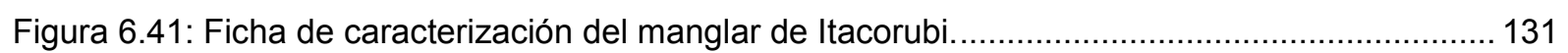

Figura 6.42: Ficha de caracterización del manglar del Río Tavares. ............................................. 133

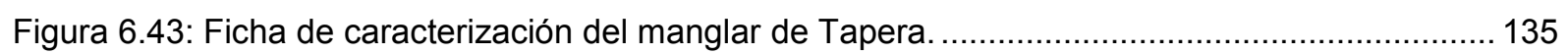

Figura 6.44: Ficha de caracterización del manglar del Río Biguaçu.................................................. 137

Figura 6.45: Ficha de caracterización del manglar de Palhoça. ....................................................... 139

Figura 6.46: Ficha de caracterización del manglar de Aririú-Cubatão.............................................. 141

Figura 6.47: Ficha de caracterización del manglar de Massiambu.................................................. 143

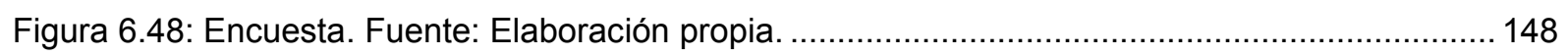

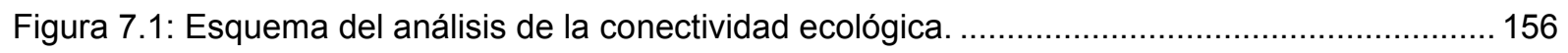

Figura 7.2: Ubicación de los paisajes de manglares del Río Ratones y de Itacorubi. ......................... 159

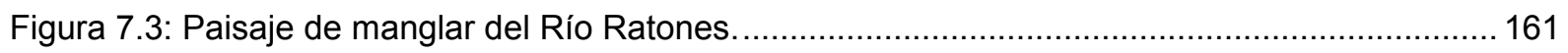

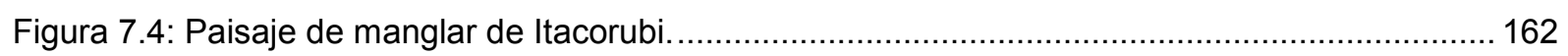

Figura 7.5: Mapa de protección ambiental municipal delimitado para Río Ratones e Itacorubi......... 164

Figura 7.6: Distribución de la nutria neotropical (Lontra longicaudis). ............................................... 166

Figura 7.7: Configuración espacial de los paisajes del Río Ratones y de Itacorubi. ........................... 169

Figura 7.8: Mapa de permeabilidad de paisaje del Río Ratones y de Itacorubi................................. 172

Figura 7.9: Mapa de conexiones potenciales en los paisajes del Río Ratones y de Itacorubi. .......... 174

Figura 7. 10: Valores de conectividad ecológica de los fragmentos de hábitat más críticos y figuras de protección ambiental de los paisajes del Río Ratones y de Itacorubi. 181 


\section{ÍNDICE DE TABLAS}

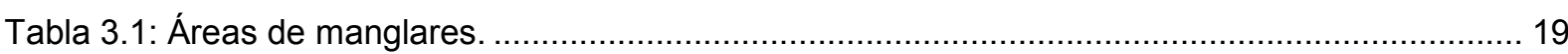

Tabla 3.2: Reducción de las áreas de manglares por continente desde 1980 hasta 2005 ................ 28

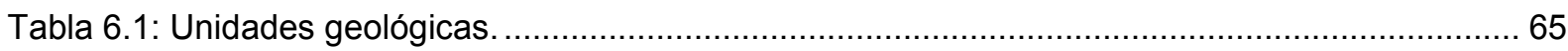

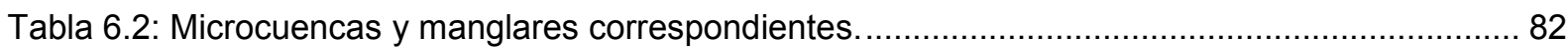

Tabla 6.3: Región Metropolitana de Florianópolis (Núcleo Metropolitano). ....................................... 97

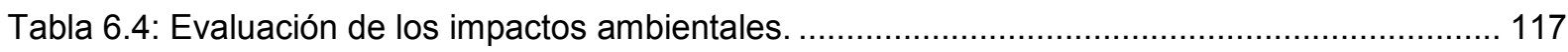

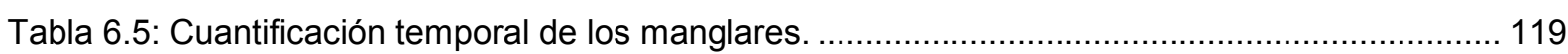

Tabla 6.6: Caracterización de los paisajes de manglares. ........................................................... 145

Tabla 6.7: Categorización de impacto de los paisajes de manglares............................................... 146

Tabla 6.8: Identificación y relación personal con los manglares...................................................... 150

Tabla 6.9: Percepción sobre los componentes bióticos y abióticos de los manglares y sus servicios ecosistémicos, identificados en amarillo los porcentajes más elevados. ....................................... 151

Tabla 6.10: Percepción sobre los impactos ambientales en los manglares, identificados en amarillo los

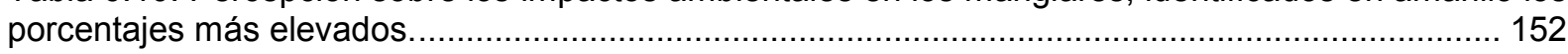

Tabla 6.11: Cambios futuros en los manglares, identificados en amarillo los porcentajes más elevados. 153

Tabla 7.1: Categorías de paisaje determinadas para Río Ratones e Itacorubi. .................................. 168

Tabla 7.2: Área y porcentaje de las categorías de paisaje del Río Ratones y de Itacorubi. .............. 170

Tabla 7.3: Valores de resistencia al desplazamiento de la especie de estudio (entre 1 y 250)........ 170

Tabla 7.4: Resultado de las métricas de conectividad ecológica para los paisajes del Río Ratones y de

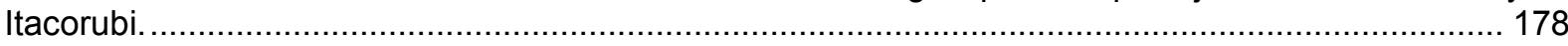

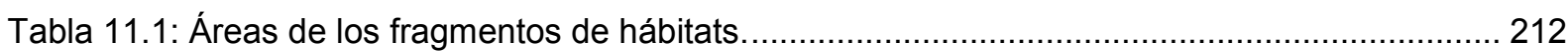

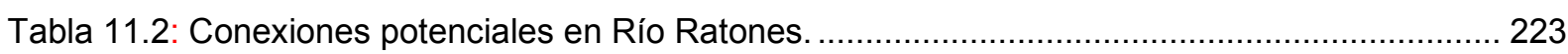

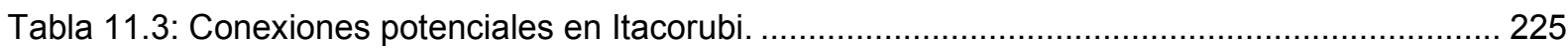

Tabla 11.4: Valores de los nodos para cada métrica de conectividad ecológica en Río Ratones. .... 233

Tabla 11.5: Valores de los nodos para cada métrica de conectividad ecológica en Itacorubi. .......... 234

Tabla 11.6: Valores normalizados de los nodos (entre 0 y 1 ) para cada métrica de conectividad

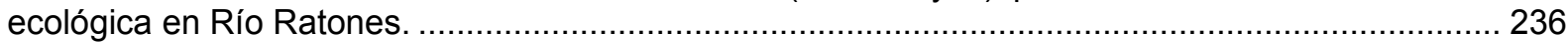

Tabla 11.7: Valores normalizados de los nodos (entre 0 y 1 ) para cada métrica de conectividad

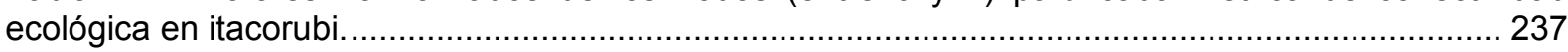

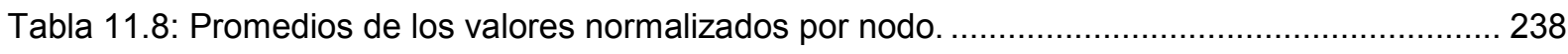

Tabla 11.9: Valores normalizados (entre 0 y 1 ) de los promedios por nodo. .................................... 239

Tabla 11.10: Áreas de protección ambiental por nodo (más críticos) de Río Ratones. ...................... 241

Tabla 11.11: Áreas de protección ambiental por nodo (más críticos) de Itacorubi............................ 242 

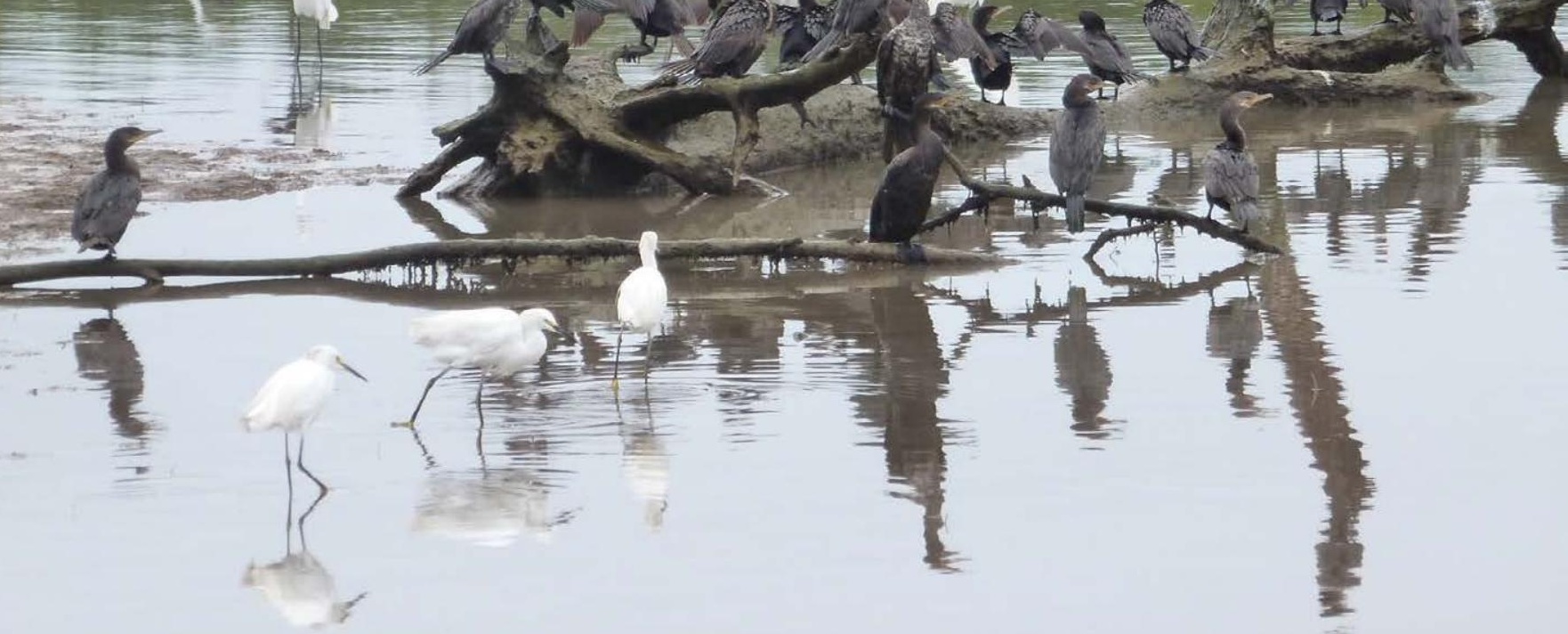

PARTE I

INTRODUCCIÓN AL TEMA Y METODOLOGÍA 


\section{INTRODUCCIÓN}

El ecosistema de los manglares está compuesto por una flora con apariencia leñosa, densa y arbórea o arbustiva, formando extensas áreas vegetadas que, a veces, se confunde con la vegetación de su entorno. Está constituida por un ecosistema híbrido al estar en la zona de transición entre el ambiente terrestre y marino. Los manglares se desarrollan principalmente alrededor de las desembocaduras de los cursos de agua dulce, prevaleciéndose en los climas cálidos y húmedos de las regiones tropicales y también subtropicales.

Los manglares proporcionan servicios ecosistémicos muy importantes debido a los diversos beneficios sostenibles que ofrecen de regulación, abastecimiento y culturales. Entre los numerosos servicios existentes, protegen contra a las intemperies de la costa y funcionan como un ecosistema de transición, pues facilitan la migración de muchas especies de animales llegados de otras localidades en busca de alimentación y refugio a estas áreas.

En Brasil existe una de las mayores cantidades de manglares del mundo, siendo el segundo mayor país en área y situándose por casi toda la costa de forma intermitente. Están mejor desarrollados en la costa Norte debido principalmente a la temperatura. En la costa Sur, el ecosistema disminuye, sin embrago, independiente de su estructura y abundancia, desempeñan un papel muy importante donde se sitúan. En cuanto a los manglares de la Región Metropolitana de Florianópolis, aunque están ubicados en la costa Sur de Brasil, su desarrollo está considerado bastante satisfactorio.

A pesar de los servicios prestados por los manglares, la reducción que vienen sufriendo por las actividades humanas es alarmante y se evidencia tanto a nivel mundial, como nacional. En la Región Metropolitana de Florianópolis se han identificado distintos impactos ambientales que afectan directa e indirectamente a los manglares, provocados por el uso del suelo a lo largo de su historia, sin una fiscalización eficiente y figuras de protección adecuadas para contener la pérdida y la fragmentación ambiental.

Los estudios y estrategias de la conectividad ecológica en los ambientes degradados por los factores antropogénicos son considerados una alternativa efectiva de planeamiento urbanístico. Tiene el propósito sostenible de lograr beneficios a partir de una red natural, donde la estructura ecológica facilita el movimiento de las especies en un paisaje, constituida de diferentes tipos de ecosistemas en amplias escalas. En este aspecto, la conectividad ecológica aplicada en los paisajes de manglares en la Región Metropolitana de Florianópolis, 
a través de conexiones de manglares entre sí y con las vegetaciones circundantes, es muy importante, pues ayuda el desplazamiento de las especies durante la fase migratoria, manteniendo la biodiversidad y conservando el ecosistema.

Para el desarrollo de la temática, la justificación, preguntas, objetivos e hipótesis de la investigación están divididos en los siguientes subcapítulos:

1.1 JUSTIFICACIÓN DEL TEMA

1.2 PREGUNTAS DE INVESTIGACIÓN

\subsection{OBJETIVOS}

1.4 HIPÓTESIS 


\subsection{JUSTIFICACIÓN DEL TEMA}

La elección y el desarrollo de esta temática tienen como argumento cuatro puntos principales, los cuales se destacan a continuación.

El primer punto se relaciona con la Región Metropolitana de Florianópolis, que pertenece a la realidad brasileña respecto a los espacios ecológicos. A pesar de su valor paisajístico, presenta poco cuidado ambiental debido al crecimiento urbano y carente de un planeamiento adecuado. Aunque existen ciudades que ofrecen espacios en contacto con la naturaleza, muchas no las poseen de una manera organizada, siendo considerados como lugares residuales en el territorio, tal como acontece en la Región Metropolitana de Florianópolis.

El segundo punto está motivado por el crecimiento económico y poblacional que viene ocurriendo en el territorio y que la sitúa entre las regiones metropolitanas de Brasil que más ha crecido en las últimas décadas. Esta situación deriva del desarrollo del turismo principalmente durante el periodo de verano, industrias, servicios, comercio, alta calidad de vida en relación a las demás ciudades brasileñas, además del potencial paisajístico con grandes diversidades ecológicas.

En el tercer punto, se vincula al estado de conservación de los manglares. Este ecosistema agrega a una gran diversidad de fauna, además de una flora muy singular debido a sus características de resistencia y resiliencia. Sin embargo, viene sufriendo variados impactos ambientales, ocasionados por el desarrollo de la ocupación del suelo a lo largo de la historia.

Por último, en el cuarto punto, es una justificación en la esfera personal, donde la autora vivió en la Región Metropolitana de Florianópolis durante toda la vida y pudo percibir los cambios que ocurrieron en los paisajes de manglares a lo largo del tiempo. Nítidamente, estos paisajes presentan belleza natural peculiar, pero vienen presentando fuertes debilidades ambientales, sin respeto a los criterios de preservación ambiental.

\subsection{PREGUNTAS DE INVESTIGACIÓN}

Las preguntas de investigación son las siguientes:

- ¿Existe conectividad ecológica en los manglares de la Región Metropolitana de Florianópolis a pesar de poseer un paisaje fragmentado?

- Si existe conectividad, ¿qué beneficios pueden tener en la Región Metropolitana de 


\section{Florianópolis?}

- Si no existe conectividad, ¿cuáles son los elementos de fragmentación de los manglares de la Región Metropolitana de Florianópolis?

- ¿Qué relaciones existen entre los manglares de la Región Metropolitana de Florianópolis y los del resto de la costa brasileña?

- ¿Las figuras de protección ambiental legal de los manglares en la escala internacional, nacional y municipal son compatibles para el mantenimiento de la conectividad ecológica constituida por los manglares?

- ¿Qué consecuencias ambientales tienen la interrupción de la conectividad ecológica en los manglares?

\subsection{OBJETIVOS}

Conforme las preguntas, el objetivo general de esta investigación es realizar un estudio sobre la existencia, beneficios y mantenimiento de la conectividad ecológica en los paisajes de manglares de la Región Metropolitana de Florianópolis. Para lo cual se contemplan los siguientes objetivos específicos:

1. Realizar una evaluación del ecosistema de los manglares en el ámbito mundial, nacional y municipal y su relación con la ocupación del suelo, identificando los principales impactos ambientales, relacionándolos con el desarrollo de la Región Metropolitana de Florianópolis a lo largo de la historia.

2. Examinar y verificar la efectividad de las figuras de protección ambiental de los manglares en el ámbito internacional, nacional y municipal, que afectan a los ubicados en la Región Metropolitana de Florianópolis.

3. Revisar los fundamentos conceptuales y teóricos sobre la conectividad ecológica para el análisis de los paisajes de manglares en general y en la Región Metropolitana de Florianópolis en particular.

\subsection{HIPÓTESIS}

Las hipótesis se basan en las siguientes afirmaciones: 
1. Los nueve paisajes de manglares existentes en la Región Metropolitana de Florianópolis se encuentran degradados por el uso del suelo a lo largo de la historia, con débil control y leyes inadecuadas de protección ambiental, existiendo una discontinuidad de sus espacios naturales con la pérdida y fragmentación de la vegetación, que impiden lograr sus servicios ecosistémicos.

2. A partir de la evaluación de la conectividad ecológica en los paisajes de manglares menos y más afectados de la Región Metropolitana de Florianópolis por la ocupación humana, es posible establecer su mantenimiento a través de estrategias ambientales adecuadas a este fin, para que los manglares puedan proporcionar sus servicios ecosistémicos. 


\section{METODOLOGÍA}

La metodología de esta investigación se basa en un estudio de la conectividad ecológica de los paisajes de manglares en la Región Metropolitana de Florianópolis. Está estructurada de acuerdo con siguiente la Figura 2.1:

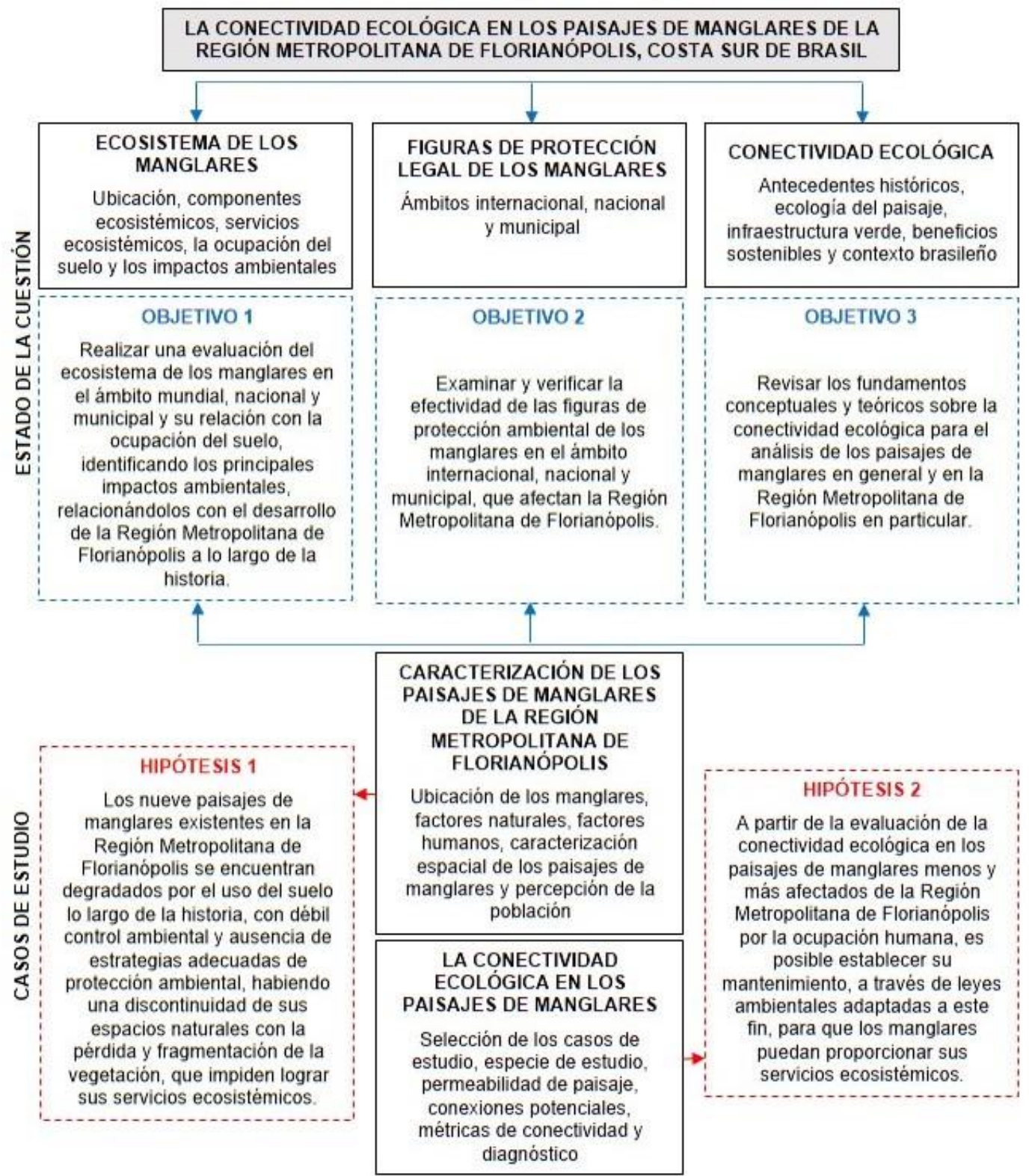

Figura 2.1: Metodología estructural. Fuente: Elaboración propia.

El estado de la cuestión se articuló en los tres objetivos específicos, según los siguientes puntos: 1) el ecosistema de los manglares (estudio de la ubicación, los componentes 
ecosistémicos, los servicios ecosistémicos, la ocupación del suelo y los impactos ambientales); 2) las figuras de protección legal de los manglares (verificación en los ámbitos internacional, nacional y municipal); y 3) la conectividad ecológica (estudio de los antecedentes históricos, la ecología del paisaje, la infraestructura verde, los beneficios sostenibles y el contexto brasileño).

El desarrollo del caso de estudio se fundamentó en los tres objetivos específicos. Inicialmente se caracterizaron los nueve paisajes de manglares existentes de la Región Metropolitana según la ubicación de los manglares, los factores naturales, los factores humanos, la caracterización espacial de los paisajes de manglares y la percepción de la población. Esta caracterización se realizó con la finalidad de comprobar la primera hipótesis.

Tras la caracterización, se evaluó la conectividad ecológica, mediante un nuevo método para la combinación de variadas métricas de conectividad, usando como base de estudio la especie Lontra longicaudis (nutria neotropical). Para el análisis, se seleccionaron dos paisajes de manglares de la Región Metropolitana de Florianópolis, correspondiente al menos y más afectado por la ocupación humana. Está segmentada según los siguientes puntos: la selección de los casos de estudio, la especie de estudio, la permeabilidad de paisaje, las conexiones potenciales, las métricas de conectividad y el diagnóstico. Esta evaluación se efectuó con la finalidad de comprobar la segunda hipótesis.

Para su desarrollo, la metodología de investigación está dividida en cinco subcapítulos, detallados a continuación:

2.1 PARTE I: introducción al tema y metodología.

2.2 PARTE II: estado de la cuestión.

2.3 PARTE III: casos de estudio.

2.4 PARTE IV: conclusiones y líneas de investigaciones futuras.

2.5 PARTE V: bibliografía y anexos. 


\subsection{PARTE I}

En la primera parte se elaboró un capítulo de introducción sobre el tema de la investigación, la justificación del tema, descripción de los objetivos general y específicos, las preguntas de investigación y la hipótesis. Posteriormente, en el según capítulo, se detalló la metodología para el desarrollo de la investigación. Esta primera parte se desarrolló en los capítulos 1: INTRODUCCIÓN y 2: METODOLOGÍA.

\subsection{PARTE II}

En la segunda parte se realizó el estado de la cuestión. Los medios de información analizados se obtuvieron a través de materiales informativos (libros, artículos, tesis y normativas), además de asistencias e intervenciones en conferencias, seminarios, congresos y mesas redondas respecto al tema propuesto. En esta parte, el estado de la cuestión se estructuró en los tres objetivos específicos de la investigación, detallados a continuación:

1. Ecosistema: evaluación de los manglares a nivel mundial y nacional a través del estudio de la ubicación geográfica, los componentes ecosistémicos bióticos y abióticos, la verificación de los servicios ecosistémicos y la relación entre el uso humano y las pérdidas ambientales. Se desarrolló en el capítulo 3: ECOSISTEMA DE LOS MANGLARES.

2. Protección ambiental: verificación de las figuras de protección ambiental de los manglares en los ámbitos internacional, nacional y municipal, que afectan a los ubicados en la Región Metropolitana de Florianópolis. Se desarrolló en el capítulo 4: FIGURAS DE PROTECCIÓN AMBIENTAL DE LOS MANGLARES.

3. Conectividad ecológica: estudio de la conectividad ecológica según sus antecedentes histórico, los conceptos y estrategias de la ecología del paisaje y la infraestructura verde y el contexto brasileño. Se desarrolló en el capítulo 5: CONECTIVIDAD ECOLÓGICA.

\subsection{PARTE III}

El caso de estudio corresponde a este apartado, que se basó en un análisis ambiental de los paisajes de manglares en la Región Metropolitana de Florianópolis, fundamentado en los tres objetivos específicos de la investigación. Los análisis procedieron de material bibliográfico y documental de la localidad y la visita de campo (realizada en los meses de marzo y abril de 
2017). Todos los mapas se realizaron mediante el software SIG - Sistema de Información Geográfica ArcGis 10.3 (georreferenciado con el sistema de proyección para WGS 1984 UTM Zona 22S). Esta parte se desarrolló en los capítulos 6: CARACTERIZACIÓN DE LOS PAISAJES DE MANGLARES DE LA REGIÓN METROPOLITANA DE FLORIANÓPOLIS y 7 : CONECTIVIDAD ECOLÓGICA EN LOS PAISAJES DE MANGLARES.

En el sexto capítulo se caracterizaron los nueve paisajes de manglares existentes de la Región Metropolitana de Florianópolis, de acuerdo con sus factores naturales (componentes ecosistémicos bióticos y abióticos) y humanos (que se relacionan con la ocupación del suelo a lo largo de la historia y sus consecuentes impactos ambientales). A partir de este estudio, se realizó el análisis de la interrelación de los factores naturales y humanos, a través de la caracterización espacial de los paisajes de manglares. Este proceso se originó a partir del análisis temporal y la caracterización espacial de cada manglar con la elaboración de fichas de caracterización. Tras la interrelación de los factores, se analizó la percepción de la población sobre los manglares.

Mediante los estudios y análisis del capítulo anterior, en el séptimo capítulo se evaluó la conectividad ecológica en los paisajes de manglares menos y más afectados por la ocupación humana en la Región Metropolitana de Florianópolis. Para este fin, se realizó un análisis en el ámbito estructural (forma espacial del paisaje) y funcional (desplazamiento de animales), basado en los principios de la ecología del paisaje, utilizando un nuevo método para la combinación de variadas métricas de conectividad. El estudio tiene como objetivo la identificación de los fragmentos de hábitat más críticos en ambos paisajes, relacionándolos con las figuras de protección ambiental vigentes para el mantenimiento de la conectividad ecológica, con la finalidad de establecer los servicios ecosistémicos de los manglares. Para su desarrollo, se utilizó una especie amenazada de la fauna local como base de estudio (nutria neotropical - Lontra longicaudis) en los siguientes pasos:

1. Selección de los casos de estudio: selección de los paisajes de manglares menos y más afectados por la ocupación humana en la Región Metropolitana de Florianópolis.

2. Especie de estudio: estudio de la nutria neotropical (Lontra longicaudis).

3. Análisis de la permeabilidad de paisaje: verificación de la resistencia al movimiento de la especie estudiada en los paisajes. Para su elaboración, se utilizó el software SIG - Sistema de Información Geográfica ArcGis 10.3. 
4. Análisis de las conexiones potenciales: identificación de las rutas de menor costo de la especie entre los fragmentos del hábitat. Para su elaboración, se utilizó el software SIG Sistema de Información Geográfica ArcGis 10.3.

5. Estudio de las métricas de conectividad: determinación de los valores de conectividad ecológica de cada fragmento de hábitat a través de una combinación de variadas métricas de conectividad de la Teoría de Grafos. Para la elaboración de las métricas, se utilizaron los software Conefor Sensinode 2.6 y MATLAB R2016a.

6. Diagnóstico: identificación y análisis estructural y funcional de los fragmentos de hábitat más críticos en los paisajes, relacionándolos con las figuras de protección ambiental vigentes para el mantenimiento de la conectividad ecológica, a fin de establecer los beneficios ecosistémicos de los manglares.

\subsection{PARTE IV}

En esta parte se establecieron las principales conclusiones a partir de los resultados obtenidos en los capítulos anteriores, sobre lo que se espera según la hipótesis de la investigación, relacionándolos con los objetivos propuestos. Tras las conclusiones, se ha desarrollado las líneas futuras de investigación. Esta parte se desarrolló en los capítulos 8: CONCLUSIONES y 9: LÍNEAS DE INVESTIGACIÓN FUTURA.

\subsection{PARTE V}

En la última parte se organizó toda la bibliografía utilizada en el documento de la tesis, a través de documentos escritos y referencias de internet. Se incluyeron también los anexos, originarios de las métricas de conectividad ecológica en los paisajes de manglares de estudio, que sirvieran para la composición de la investigación. Esta parte de desarrolló en los capítulos 10: BIBLIOGRAFÍA y 11: ANEXOS. 


\section{PARTE II}

\section{ESTADO DE LA CUESTIÓN}




\section{ECOSISTEMA DE LOS MANGLARES}

Los manglares son una tipología de ecosistema natural que se desarrollan entre la transición del medio terrestre y el marino, mezclándose el agua dulce con la procedente del mar. Debida a su ubicación, los manglares también pueden ser llamados como bosques de marea, bosques costeros o bosques tropicales oceánicos (Kathiresan y Bingham, 2001). Se componen de especies con estructura arbórea o arbustiva, donde las condiciones morfológicas son adecuadas a su establecimiento, generando variados servicios ecosistémicos. Sin embargo, vienen sufriendo una grave degradación con la pérdida de su espacio, provocada por las actividades humanas.

En este capítulo se realiza una evaluación del ecosistema de los manglares a nivel mundial y nacional (Brasil). Está dividido en cuatro subcapítulos, detallados a continuación:

3.1 UBICACIÓN: situación de los manglares.

3.2 COMPONENTES ECOSISTÉMICOS: estudio de los componentes bióticos y abióticos de los manglares.

3.3 SERVICIOS ECOSISTÉMICOS: estudio de los beneficios sostenibles generados por los manglares.

3.4 EL USO HUMANO Y LAS PÉRDIDAS AMBIENTALES: estudio de la pérdida de los manglares provocada por las actividades humanas. 


\subsection{UBICACIÓN}

El ecosistema de los manglares se forma principalmente en las costas tropicales, pero también subtropicales, prevaleciendo las regiones de clima cálido y húmedo. Se concentra en América del Sur, América Central, África, parte insular del Sudeste de Asia y en el Norte de la Oceanía. Están ubicados en un total de 123 países y cubren una superficie de cerca de 150.000 km². Aproximadamente la mitad de los manglares existentes en el mundo se encuentran en los países de Indonesia, Brasil, Australia, México, Nigeria y Malasia, según muestra la Figura 3.1 y la Tabla 3.1.

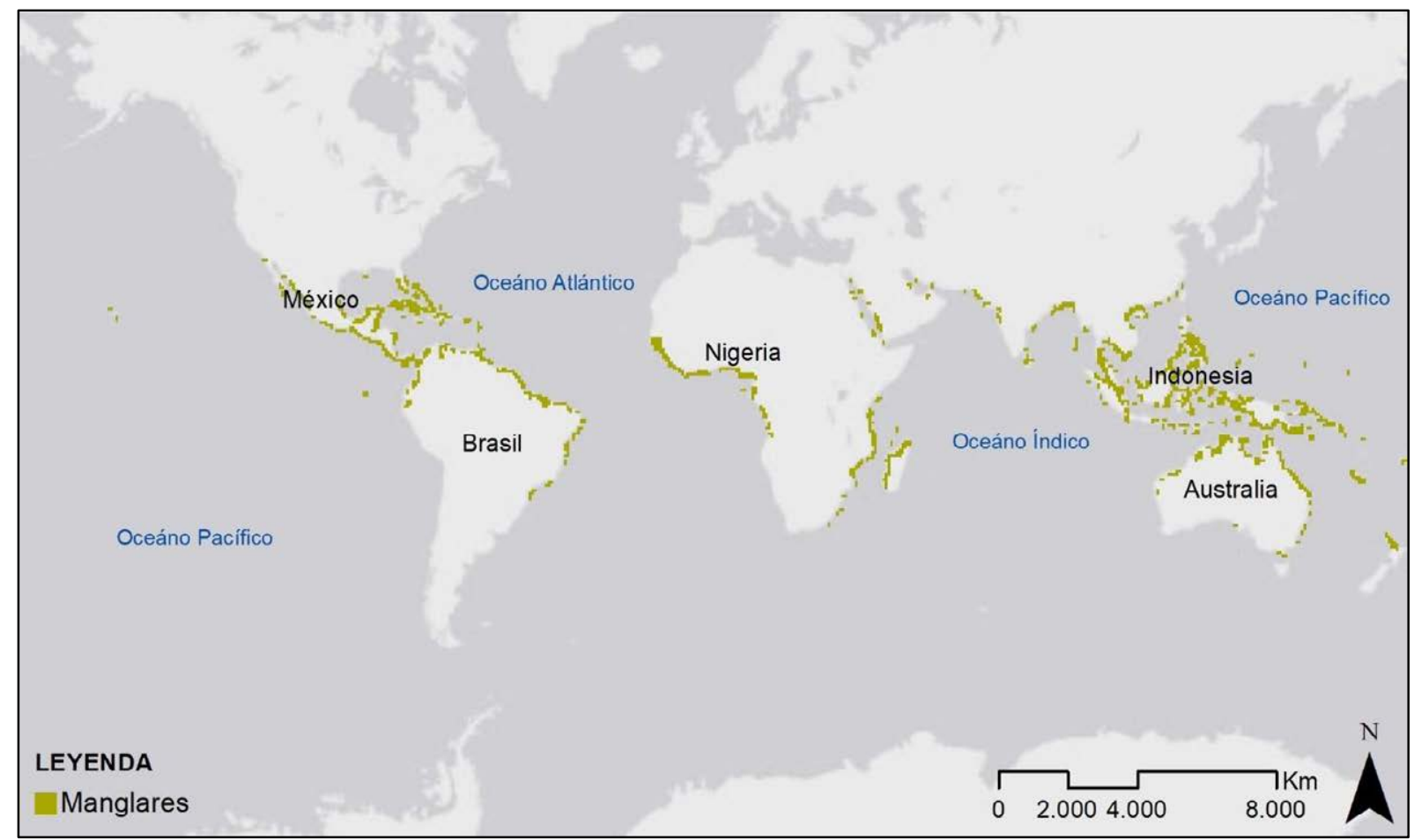

Figura 3.1: Ubicación de los manglares en el mundo. Fuente: Elaboración propia con los datos de United Nations Environmet Programme, World Conservation Monitoring Centre, UNEP-WCMC (2010).

Brasil está considerado como el segundo país con mayor extensión de manglares del mundo y se pueden encontrar a lo largo de casi toda la costa del territorio. Se ubican en 16 Estados Federales de los 17 que se conectan con el mar. Conforme Schaeffer-Novelli el al. (1990), ocurren intermitentemente en la costa brasileña desde Cabo Orange ( $4^{\circ} 30^{\prime}$ Norte), en Amapá, hasta el Municipio de Laguna (28 $30^{\prime}$ Sur), en el Estado de Santa Catarina (Figura 3.2). 


\begin{tabular}{|l|c|c|}
\hline \multicolumn{1}{|c|}{ Países } & Áreas de manglares $\left.\mathbf{( K m}^{2}\right)$ & Porcentaje global \\
\hline Indonesia & 31.894 & $20,9 \%$ \\
\hline Brasil & 13.000 & $8,5 \%$ \\
\hline Australia & 9.910 & $6,5 \%$ \\
\hline México & 7.701 & $5,0 \%$ \\
\hline Nigeria & 7.356 & $4,8 \%$ \\
\hline Malasia & 7.097 & $4,70 \%$ \\
\hline
\end{tabular}

Tabla 3.1: Áreas de manglares. Fuente: Elaboración propia con los datos de Spalding et al. (2010, p. 17).

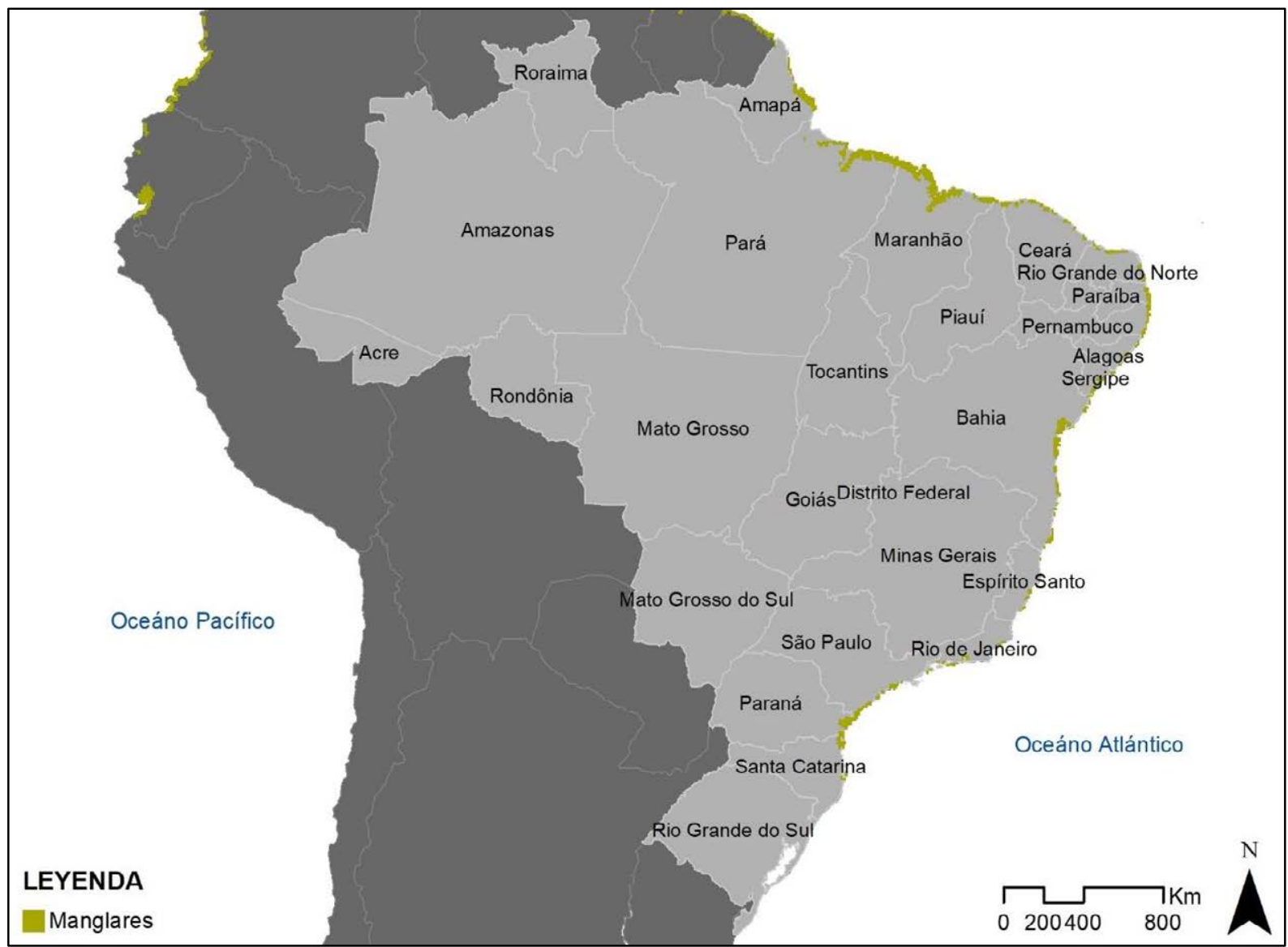

Figura 3.2: Ubicación de los manglares en Brasil. Fuente: Elaboración propia con los datos de UNEPWCMC (2010).

\subsection{COMPONENTES ECOSISTÉMICOS}

La definición de ecosistema se da por la unión de los componentes bióticos y abióticos que comparten los mismos hábitats. Los componentes abióticos son derivados del aspecto estructural físico del medio ambiente, mientras los bióticos son todos los organismos vivos que se adaptan dentro de una determinada estructura física. 
Hay variados ecosistemas en el globo terrestre, entre ellos los acuáticos, terrestres, híbridos y microbianos. Los manglares son parte de un ecosistema híbrido, o sea, terrestre y acuático, compuestos por una combinación de componentes bióticos y abióticos, definidos en las siguientes secciones.

\subsubsection{Componentes abióticos}

Los principales componentes abióticos donde se desarrollan los manglares son determinados por diversos factores, entre los cuales se pueden destacar:

1. Topografía: los manglares se ubican en las costas de baja altitud, alrededor de las lagunas costeras, esteros, desembocadura de ríos y arroyos. En zonas que posibilitan la entrada de inundación de la marea y protegidas de las olas y corrientes marinas. La topografía también influye en el área de los manglares. Cuanto mayor es el área que proporciona la inundación, mayor es la extensión de los manglares.

2. Inundación: el proceso de inundación se origina a través de la elevación del nivel del mar y tiene la función de transportar los sedimentos marinos. El encuentro del agua del mar con el agua de los ríos origina el sustrato responsable por el establecimiento de la vegetación. Este sustrato se compone básicamente de limo, arcilla y es rico en materia orgánica (Walsh, 1974). Cuanto mayor sea la amplitud de la marea, mayor será la altura de la estructura del bosque.

3. Salinidad: la cantidad de agua dulce proveniente de los ríos junto con el agua salada del mar combinan un agua salobre, responsable de la formación de los manglares. Sin embargo, existen manglares donde la mezcla del agua dulce no ocurre a través de los ríos, sino por lluvias, sucediendo este hecho principalmente en las islas oceánicas. En este aspecto, la pluviosidad es también considerada un factor de gran importancia.

4. Temperatura: la temperatura del ambiente es fundamental para la supervivencia de los manglares, siendo más adaptables a los climas cálidos. Se adaptan generalmente donde la temperatura media del mes más frío no supera alrededor de los $20^{\circ} \mathrm{C}$ (Walsh, 1974), aunque hay una temperatura mínima específica para cada especie de manglar. En este caso, cuanto mayor sea la latitud, mejor será el desarrollo de los manglares en relación a su estructura. Por otro lado, las latitudes más bajas son un factor limitante para los manglares. Según el Food and Agriculture Organization of the United Nations (FAO, 2007, 
p. 3), en estas zonas, a menudo aparecen solo como árboles pequeños, pero aún pueden desempeñar un papel esencial para las comunidades locales.

\subsubsection{Componentes bióticos}

Los manglares son una formación leñosa, densa y arbórea o arbustiva. Su grado de desarrollo está condicionado a los aspectos abióticos en que viven. De acuerdo con Hogarth (2007, p. 3), los manglares comprenden unas 55 especies en 20 géneros, pertenecientes a 16 familias. Sin embargo, el número exacto de especies todavía está en discusión, oscilando entre 50 y 70 según las diferentes clasificaciones (FAO, 2007, p. 3).

Las características de las especies de los manglares son bastante similares entre sí (Figura 3.3). Sus hojas son perennes, suculentas y de borde entero. Poseen glándulas especializadas, las cuales permiten la secreción de los excesos salinos, siendo consideradas especies halófitas. El sistema radical presenta raíces respiratorias (neumatóforos), pues el sustrato es muy pobre en oxígeno y también cumple la función de sostenerse en el suelo lodoso. Las raíces pueden tener diferentes estructuras dependiendo la especie, con geotropismo positivo o negativo. En cuanto a la reproducción, se consideran vivíparos. Sus semillas germinan aún fijas en los árboles, denominadas como propágalos, garantizando así una mejor resistencia a las adversidades presentes en el medio. 

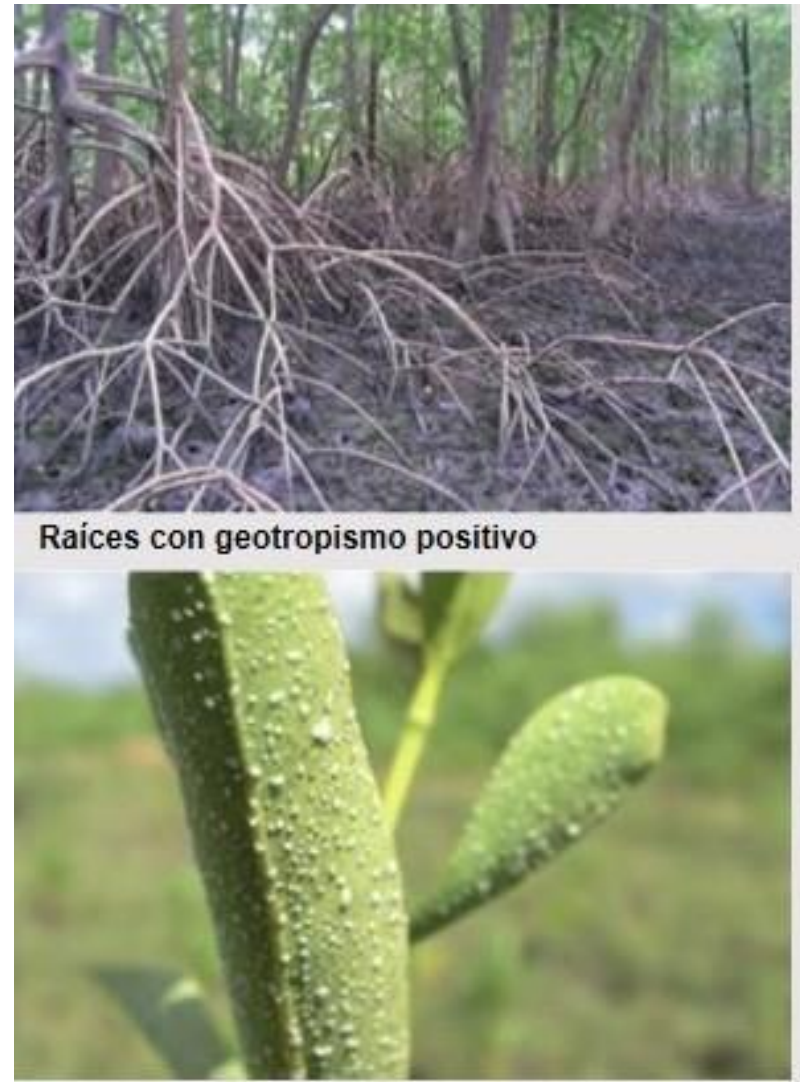

Sal excretada por las hojas

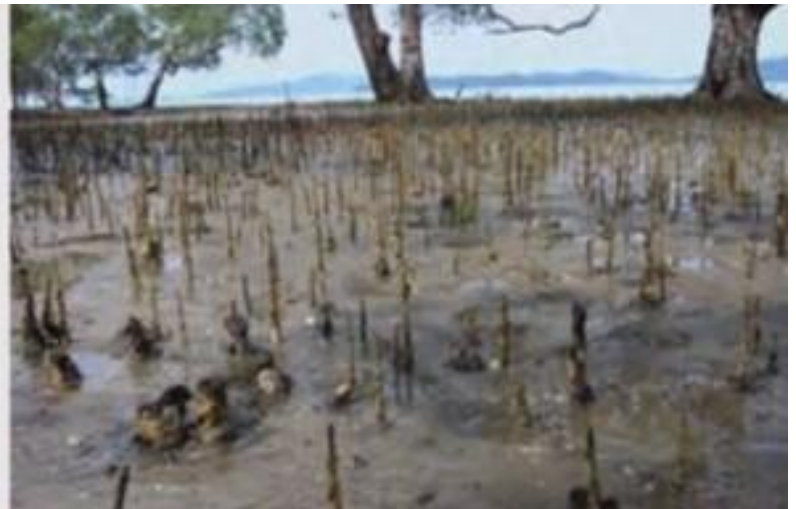

Raices con geotropismo negativo

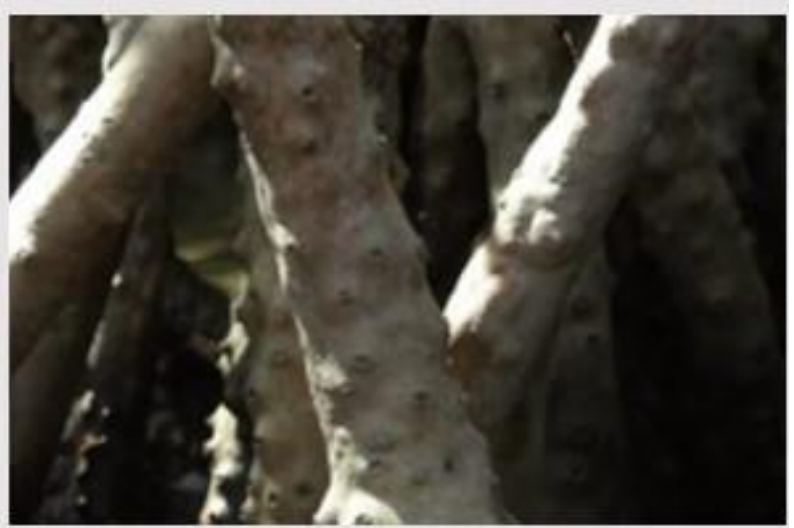

Propágalos

Figura 3.3: Características de la flora de los manglares. Fuente: Elaboración propia con los datos de Spalding et al. (2010, p. 3 y 4).

Existen también las especies asociadas a los manglares, con especificidades ambientales similares, como la tolerancia a la sal, que se sitúan en los bordes de los manglares. Una gran variedad de epífitas también crecen en los árboles de manglar; sin embargo, muchas no toleran la sal y, por lo tanto, solo crecen en las partes más altas (Hogarth, 2007, p. 3).

Es común encontrar en los manglares y en las especies asociadas una zonificación en bandas monoespecíficas paralelas a la costa. Esta zonificación sigue un patrón específico para cada región, dependiendo de las características de los componentes abióticos. Está generalmente organizada por la topografía local, el suelo, los rangos de mareas y la salinidad (FAO, 2007, p. 2).

En cuanto a la fauna, existen muchas especies de invertebrados y vertebrados, venidos de los ambientes terrestres, marinos o de agua dulce. Según Hogarth (2007, p. 73 ), una gran proporción de animales proceden de los entornos terrestres vecinos, pues los manglares no son muy diferentes de los bosques que están a su alrededor, siendo a menudo imperceptibles su distinción. 


\subsubsection{Manglares en Brasil}

Hay siete especies diferentes de manglar y cuatro géneros en Brasil: Avicennia germinans, Avicennia schaueriana, Conocarpus erectus, Laguncularia racemosa, Rhizophora harrisonii, Rhizophora mangle y Rhizophora racemosa (FAO, 2007, p. 44). Gran parte de los manglares de Brasil forman parte de uno de los siete ecosistemas de la Mata Atlántica1 ${ }^{1}$, estimado como el bosque más afectado del territorio brasileño y que se encuentra entre los más ricos del mundo (Figura 3.4).

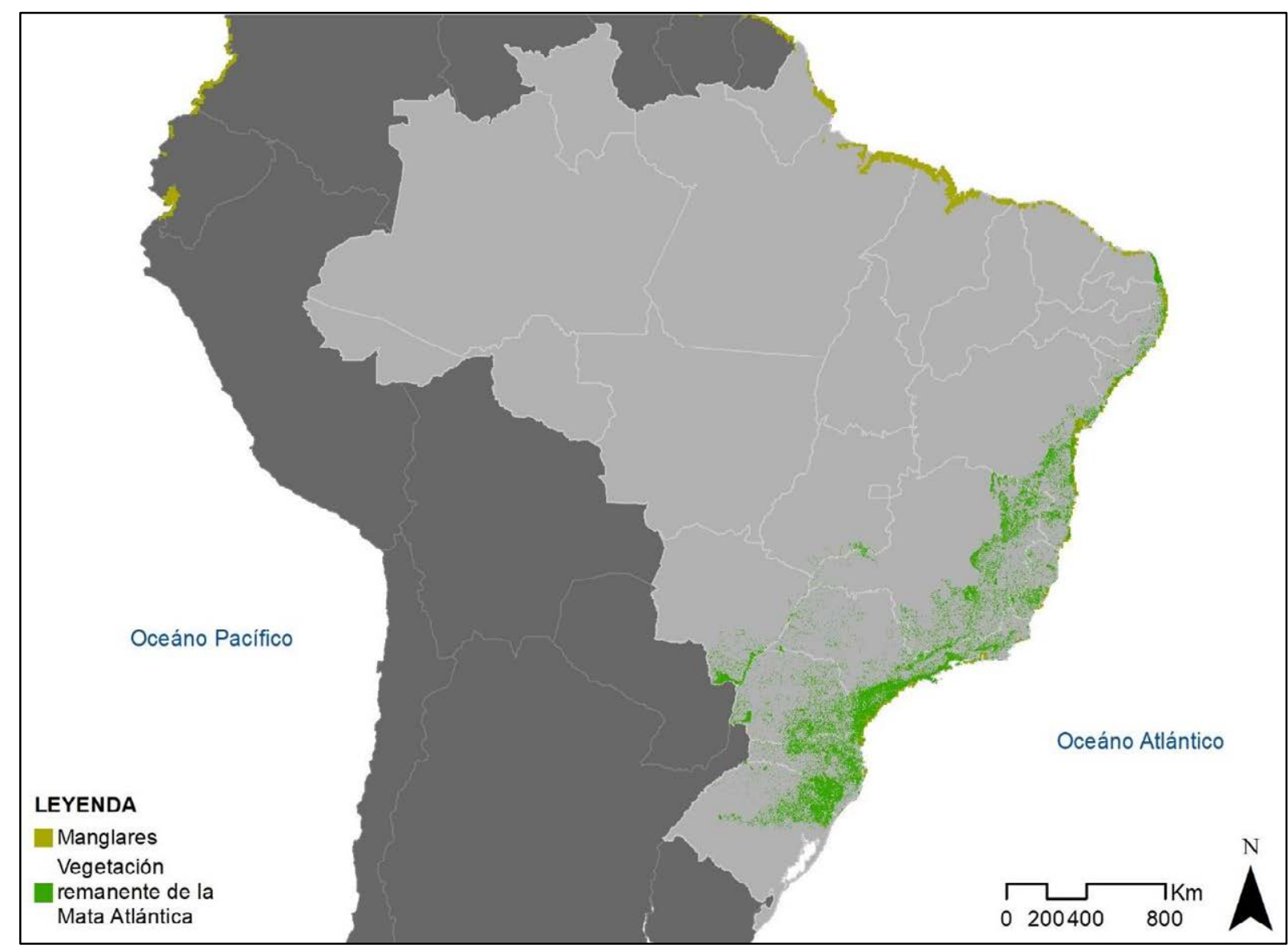

Figura 3.4: Vegetación restante de la Mata Atlántica. Fuente: Elaboración propia con los datos de UNEP-WCMC (2010) y Ministério do Meio Ambiente, MMA (2008).

El grado de desarrollo de los manglares está directamente condicionado a los factores físicos, donde se establecen con más abundancia y mayor estructura en la costa Norte, mientras disminuye en la Costa Sur. Según esta afirmación y de acuerdo con Schaeffer-Novelli et al.

\footnotetext{
${ }^{1}$ Los siete ecosistemas de la Mata Atlántica son: la Selva Ombrófila Densa, la Selva Ombrófila Abierta, la Selva Ombrófila Mista, la Selva Estacional Decidual, la Selva Estacional Semidecidual, la Formación Pionera (manglares) y los Campos de Altitud.
} 
(1990), los manglares brasileños están divididos en ocho segmentos, según se observa en la Figura 3.5 .

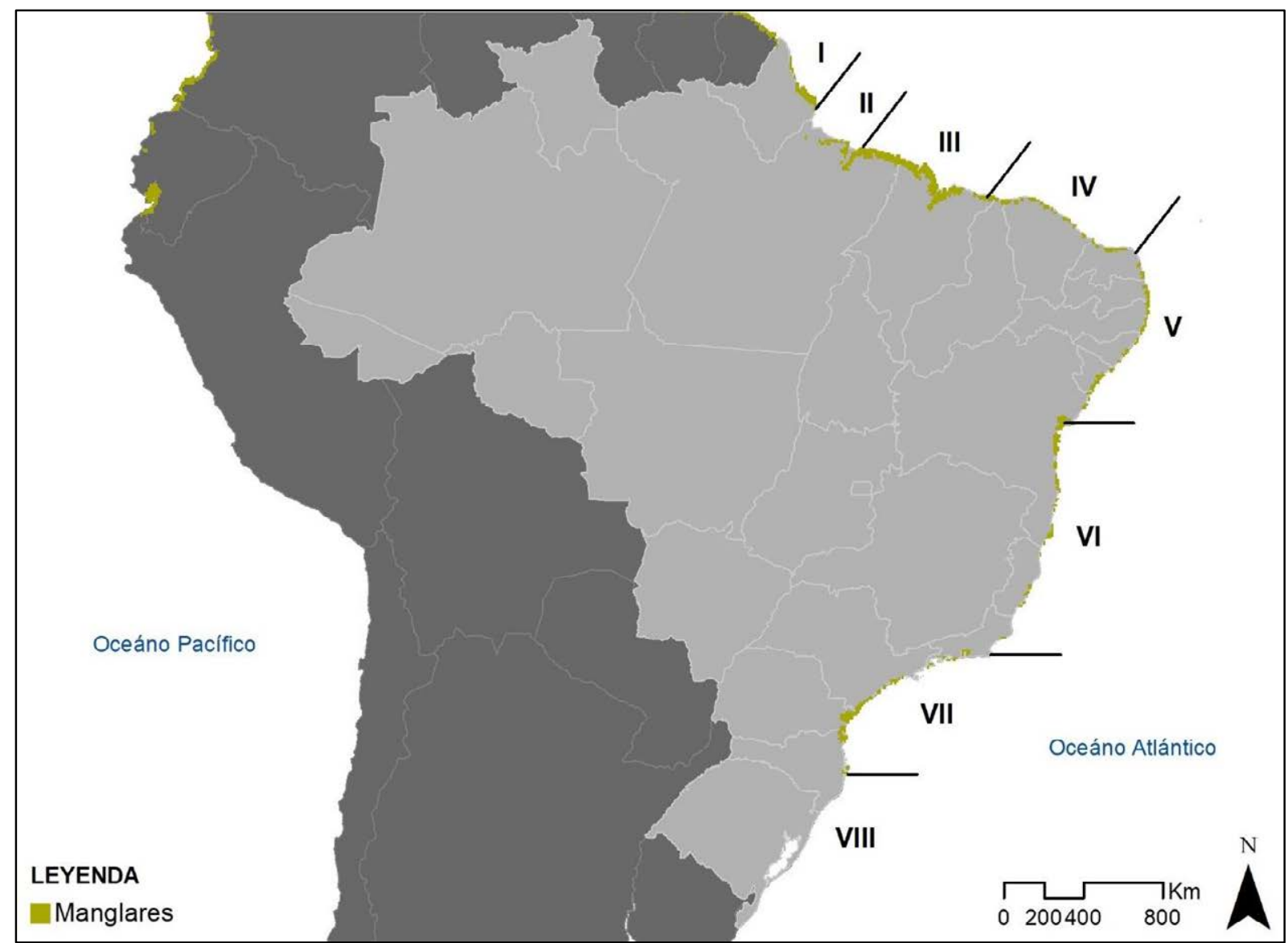

Figura 3.5: Segmentación de los manglares en la costa brasileña. Fuente: Elaboración propia con los datos de UNEP-WCMC (2010) y Schaeffer-Novelli et al. (1990).

Los segmentos están caracterizados según los aspectos fisiográficos y estructurales, detallados a continuación:

1. Segmento I (Latitudes entre $04^{\circ} 30^{\prime}$ Norte y $01^{\circ} 40^{\prime}$ Norte): este segmento es caracterizado por bosques dominados por el género Avicennia. El género Rhizophora ocupa el estuario de los ríos, donde la influencia marina es directa y Laguncularia ocupa la parte interior de los bosques. Estos manglares colonizan los ríos costeros, extendiéndose hasta considerables distancias.

2. Segmento II (Latitudes entre $01^{\circ} 40^{\prime}$ Norte y $00^{\circ} 36^{\prime}$ Sur): el desarrollo de los manglares es escaso en este segmento debido a la influencia de la descarga fluvial del Río Amazonas. El género Avicennia se forma en lugares de pequeña elevación y baja salinidad, mientras Rhizophora ocupa lugares con influencias marinas más significativas. 
3. Segmento III (Latitudes entre $00^{\circ} 36^{\prime}$ Sur y $02^{\circ} 15^{\prime}$ Sur): en este segmento, el género Rhizophora domina los bosques de manglares en las partes de baja altitud. En las regiones más elevadas son colonizadas por Avicennia y Laguncularia. El género Conocarpus se encuentra en las localidades de transición con el suelo seco.

4. Segmento IV (Latitudes entre $02^{\circ} 15^{\prime}$ Sur y $05^{\circ} 08^{\prime}$ Sur): los manglares son poco desarrollados a lo largo de este segmento debido a la falta de aporte de agua dulce, asociada a estaciones secas prolongadas. Las altas concentraciones de sales también limitan los manglares en las desembocaduras de los ríos.

5. Segmento $V$ (Latitudes entre $05^{\circ} 08^{\prime}$ Sur y $13^{\circ} 00^{\prime}$ Sur): a causa de las fuertes olas que ocurren en este segmento, los manglares se desarrollan en áreas protegidas, asociados a estuarios y lagunas costeras. Destacan los géneros Rhizophora y Laguncularia. En las partes más internas de los bosques, Avicennia y Laguncularia forman bosques mixtos.

6. Segmento $\mathrm{VI}$ (Latitudes entre $13^{\circ} 00^{\prime}$ Sur y $23^{\circ} 00^{\prime}$ Sur): en este segmento, los tres géneros de manglares se encuentran (Avicennia, Rhizophora y Laguncularia), pudiendo componer tanto formaciones mixtas, como monoespecíficas.

7. Segmento VII (Latitudes entre $23^{\circ} 00^{\prime}$ Sur y $29^{\circ} 20^{\prime}$ Sur): los bosques presentan gradiente en términos estructurales, con individuos de estatura mayores bordeando los estuarios y los canales de algunos ríos. Los bosques de Avicennia, Rhizophora y Laguncularia pueden ser mixtos o monoespecíficos.

8. Segmento VIII (Latitudes entre $29^{\circ} 20^{\prime}$ Sur y $33^{\circ} 45^{\prime}$ Sur): en este segmento las bajas temperaturas en el invierno y la gran amplitud térmica inhiben el crecimiento de las especies de manglares.

Los manglares están presentes en casi todos los segmentos, con mayor desarrollo en los segmentos I y III. Sin embargo, debido a las bajas temperaturas, no se encuentran en el segmento VIII. Según Schaeffer-Novelli et al. (1990), el límite latitudinal para las especies de manglares ocurre en la costa del Estado de Santa Catarina (segmento VII), a los $27^{\circ} 30^{\prime}$ Sur para el género Rhizophora mangle (Región Metropolitana de Florianópolis) y a los $28^{\circ} 30^{\prime}$ Sur para Avicennia schaueriana y Laguncularia racemosa (Municipio de Laguna).

\subsection{SERVICIOS ECOSISTÉMICOS}

La flora de los manglares ofrece múltiples beneficios sostenibles, destacados por la 
comunidad científica (Alongi, 2008; FAO, 2007; Hogarth, 2007; Kathiresan y Bingham, 2001; Spalding et al., 2010). Está altamente adaptada para sobrevivir frente a las intemperies de la costa, ejerciendo variados servicios de regulación. Funciona como un sistema natural de amortiguamiento en las inundaciones, la intrusión salina y la prevención de la erosión de la costa, siendo muy resistente y resiliente, lo que puede atenuar las perturbaciones del cambio climático.

Ejerce también como filtro biológico al remover nutrientes y toxinas, atenúa la radiación solar y favorece la creación de suelos. Debido a su capacidad de almacenamiento de cantidades considerables de carbono orgánico en los suelos, tiene también un papel importante en el proceso de mitigación de la contaminación proveniente de los gases tóxicos. Asimismo, ayuda en la regularización del clima, la purificación del aire y la atenuación de la contaminación acústica.

Presta también servicios de abastecimiento, pues apoya la pesca costera de peces, gambas y ostras, siendo considerada como un hábitat productivo. Debido a la abundancia de alimentos y al ser un área óptima para el refugio, gran variedad de la fauna terrestre y marina migra hacia los manglares durante una parte o permanece la totalidad de su ciclo de vida (Nagelkerken et al., 2008), funcionando como un ecosistema de transición. Actúan especialmente como refugios naturales para la reproducción y el desarrollo en las primeras etapas de vida de distintas especies de la fauna. Puesto que es un área de transición en la migración de las especies, se considera que son áreas fundamentales respecto a la conectividad ecológica con otros ecosistemas adyacentes, siendo fundamental para la conservación de la diversidad biológica.

Según FAO (2007, p. 6), la creciente popularidad de las actividades de ecoturismo representa una fuente de ingreso valiosa y sostenible para las poblaciones locales donde los bosques son de fácil acceso. De esta forma, los manglares también proporcionan servicios culturales muy importantes para la calidad de vida de las personas, como la disminución de estrés por el contacto con la naturaleza y el valor estético, generando ambientes de ocio, actividades culturales y la facilitación del ejercicio físico. Conforme Maller et al. (2006), existen pruebas significativas que los usuarios de estos espacios naturales mejoran la salud humana y el estado de bienestar, debiendo incorporarse en las estrategias de la salud pública. 


\subsection{EL USO HUMANO Y LAS PÉRDIDAS AMBIENTALES}

A pesar de los muchos beneficios proporcionados por los manglares, las perturbaciones provocadas por las actividades humanas ha debilitado el desarrollo de este ecosistema, convirtiéndola en una formación costera muy perjudicada por la pérdida de las áreas de los manglares.

Los principales motivos de la reducción de los manglares están asociados con la concurrencia por la tierra para el desarrollo urbano a causa de las presiones demográficas en las zonas costeras, la construcción de infraestructura turística, la agricultura (como la plantación de sal y arroz en las localidades de manglares), la acuicultura (especialmente para la producción de camarones y peces), la explotación de madera, la construcción de presas (que desvía el agua y modifica la entrada de sedimentos, nutrientes y agua dulce) y la contaminación (FAO, 2007; Spalding et al., 2010). Más específicamente, se detectó que en Asia, Caribe y América Latina la deforestación ha sido causada principalmente por la conversión a gran escala de estas áreas para la acuicultura y la infraestructura turística, sobre todo entre 1980 y 1990 (FAO, 2007, p. 13).

Estudios recientes han identificado las amenazas y vulnerabilidades que han sufrido los manglares a nivel mundial por diferenciados usos humanos, como los ejemplos de la zona conurbana de Veracruz, México (Chong Garduño, 2015); el turismo y el desarrollo comercial y residencial en Roatán, Honduras (Doiron y Weissenberger, 2014); la acuicultura en Orissa, India (Pattanaik y Prasad, 2011); y la acuicultura y el desarrollo residencial en Hainan, China (Xin et al., 2014).

Se estima que hubo una pérdida considerable de manglar en el mundo entre 1980 y 2005 de 3,5 millones de hectáreas, una disminución de un 19\% aproximadamente. A nivel continental, Asia sufrió la mayor pérdida de hectárea de manglar, más de 1,9 millones entre los periodos de 1980 y 2005 . América del Norte y Central y África también contribuyeron significativamente a la disminución de la superficie de manglares en estos años, con pérdidas de cerca de 690.000 ha y 510.000 ha, respectivamente (Tabla 3.2). 


\begin{tabular}{|l|c|c|c|c|}
\hline \multirow{2}{*}{ Continentes } & \multicolumn{4}{|c|}{ Áreas de manglares 1000(ha) } \\
\cline { 2 - 5 } & $\mathbf{1 9 8 0}$ & $\mathbf{1 9 9 0}$ & $\mathbf{2 0 0 0}$ & $\mathbf{2 0 0 5}$ \\
\hline África & 3.670 & 3.428 & 3.218 & 3.160 \\
\hline Asia & 7.769 & 6.741 & 6.163 & 5.858 \\
\hline América del Norte y Central & 2.951 & 2.592 & 2.352 & 2.263 \\
\hline América del Sur & 2.222 & 2.073 & 1.996 & 1.978 \\
\hline Oceanía & 2.181 & 2.090 & 2.012 & 1.972 \\
\hline Mundo & 18.794 & 16.925 & 15.740 & 15.231 \\
\hline \multirow{2}{*}{ Continentes } & & Tasa de reducción de manglares (\%) & $\mathbf{1 9 8 0 - 2 0 0 5}$ \\
\cline { 2 - 5 } & $\mathbf{1 9 8 0 - 1 9 9 0}$ & $\mathbf{1 9 9 0 - 2 0 0 0}$ & $\mathbf{2 0 0 0 - 2 0 0 5}$ & $-13,90$ \\
\hline África & $-0,66$ & $-0,61$ & $-0,36$ & $-24,60$ \\
\hline Asia & $-1,32$ & $-0,86$ & $-0,99$ & $-23,31$ \\
\hline América del Norte y Central & $-1,22$ & $-0,93$ & $-0,76$ & $-10,98$ \\
\hline América del Sur & $-0,67$ & $-0,37$ & $-0,18$ & $-9,58$ \\
\hline Oceanía & $-0,42$ & $-0,37$ & $-0,40$ & $-18,96$ \\
\hline Mundo & $-0,99$ & $-0,70$ & $-0,65$ & \\
\hline
\end{tabular}

Tabla 3.2: Reducción de las áreas de manglares por continente desde 1980 hasta 2005.Fuente: Elaboración propia con los datos de FAO (2007, p. 9).

Sin embargo, en las últimas décadas se observa que la tasa de reducción de los manglares en todas las regiones continentales ha disminuido, en un total de $0,34 \%$ entre las décadas de 1980 y 1990 y el período de 2000 y 2005 . Se concluye que ha habido una mayor preocupación sobre el valor ecosistémico de los manglares. En algunos países también se ha observado la restauración de las áreas de manglares a través de la regeneración natural o la plantación activa (FAO, 2007, p. 6). Sin embargo, se verifica que la reducción de las áreas de manglares en el último período analizado, de 509.000 ha, es considerada todavía muy alta, necesitada de medidas y fiscalizaciones más efectivas para su conservación.

Según los estudio de FAO (2007, p. 44) sobre los manglares de Brasil, entre 1980 у 2005, hubo una pérdida total de un 4,8\% (-50.000 ha). Entre las décadas de 1980 y 1990, hubo una reducción del 0,3\% (-35.000 ha), y entre 1990 y 2000, hubo una reducción del 0,1\%, (-15.000 ha), principalmente a lo largo de la costa Sur, por estar más urbanizado. Sin embargo, entre 2000 y 2005 no hubo pérdidas, sumando un total de 1.000 .000 ha de manglares. Estos datos significan que la conciencia de la importancia de este ecosistema costero está aumentando lentamente. Sin embargo, necesitan esfuerzos para su restauración.

Históricamente, la devastación de los manglares de Brasil comenzó en el periodo colonial, a partir del siglo XVI para la obtención de tinta (Alves, 2001) y, más recientemente, para el desarrollo urbano, la acuicultura (especialmente en la región noreste del país), además de la 
contaminación y del uso no sostenible de sus recursos naturales. Se estima una pérdida total del $40 \%$ respecto al estado original y del $25 \%$ desde el inicio del siglo XX, según el Instituto Chico Mendes de conservação da biodiversidade (ICMBio) ${ }^{2}$, algo que perjudica el equilibrio ecológico, generando graves impactos ambientales.

\footnotetext{
2 ICMBio, Instituto Chico Mendes de conservação da biodiversidade. Disponible en http://www.icmbio.gov.br/
} (fecha de consulta: febrero de 2017). 


\section{FIGURAS DE PROTECCIÓN LEGAL DE LOS MANGLARES}

Frente al panorama de las pérdidas de los manglares por las actividades humanas a nivel mundial y nacional (Brasil), verificado en el capítulo anterior ${ }^{3}$, se han llevado a cabo variadas políticas y proyectos de medidas legales de protección, que podrán impedir su degradación, contribuyendo a la necesidad de la preservación.

Por lo tanto, en este capítulo se analizan las figuras más importantes para la protección de los manglares en el contexto internacional, nacional y municipal, que afectan a los ubicados en la Región Metropolitana de Florianópolis, esquematizadas en la Figura 4.1.

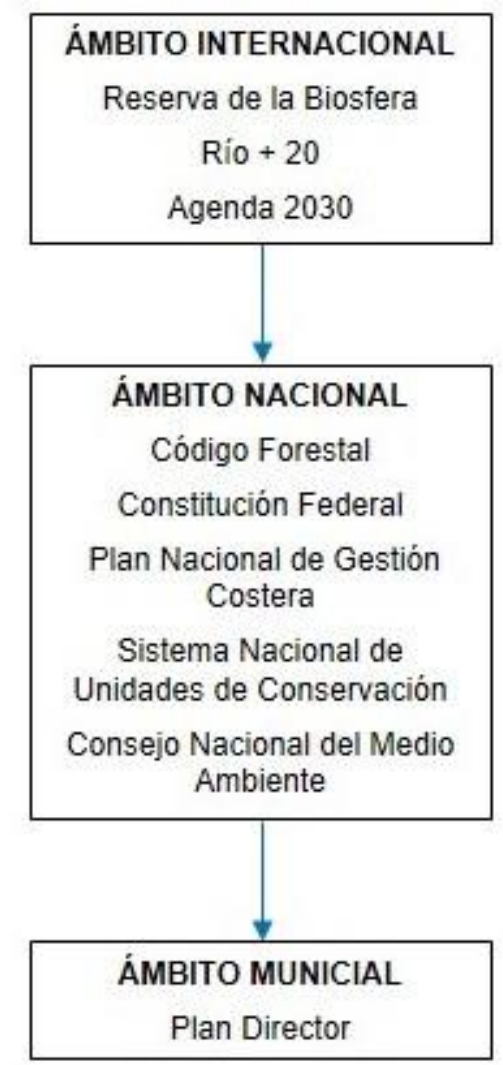

Figura 4.1: Figuras de protección legal de los manglares. Fuente: Elaboración propia.

Están desarrolladas en los siguientes subcapítulos, detallados a continuación:

4.1 ÁMBITO INTERNACIONAL: análisis de los instrumentos que protegen los manglares en

${ }^{3}$ Demostrado en el subcapítulo 3.4 . 
PARTE II. Capítulo 4. FIGURAS DE PROTECCIÓN LEGAL DE LOS MANGLARES

la escala mundial.

4.2 ÁMBITO NACIONAL: análisis de las leyes que protegen los manglares en el territorio brasileño.

4.3 ÁMBITO MUNICIPAL: análisis de las leyes que protegen los manglares en la escala municipal, teniendo como referencia el Municipio de Florianópolis. 


\section{1 ÁMBITO INTERNACIONAL}

En la escala mundial existen variadas figuras desarrolladas para la protección de los manglares, a partir de leyes, directrices, conferencias y convenciones. En este subcapítulo se han seleccionado solamente los instrumentos de ámbito internacional que afectan a los manglares en la Región Metropolitana de Florianópolis. Entre ellos, están la Reserva de la Biosfera, el Río+20 y la Agenda 2030.

Es importante reconocer que el éxito de las figuras de protección internacionales depende de la realidad, la circunstancia y el nivel de desarrollo de cada país independiente. El gobierno debe establecer sus estrategias de planeamiento y gestión ambiental de acuerdo con sus políticas nacionales, apoyándose en las directrices mundiales.

\subsubsection{Reserva de la Biosfera}

La Reserva de la Biosfera son zonas reconocidas por el Programa El hombre y la Biosfera (Man and the Biosphere Programme, MaB), creado en 1971 por la Organización de las Naciones Unidas para la Educación, la Ciencia y la Cultura (UNESCO). Este programa establece las bases científicas para la mejora de las relaciones entre las personas y el ambiente, a través del uso racional y sostenible y la conservación de los recursos de la biosfera. Propone investigaciones que abarca las dimensiones ecológicas, sociales y económicas de la pérdida de la biodiversidad y su reducción.

Los sitios de la Reserva de la Biosfera encajan en la conservación de los manglares por constituir, entre otras, las zonas de ecosistemas costeros. De acuerdo con los datos de UNESCO ${ }^{4}$, existen 669 Reservas en 120 países, y en Brasil hay un total de siete Reservas. La Reserva de la Biosfera Mata Atlántica compone una gran parte de los manglares de Brasil (inclusive los de la Región Metropolitana de Florianópolis), entre otros ecosistemas ${ }^{5}$. Fue designada en 1993, siendo la pionera de las Reservas de la Biosfera brasileña. El objetivo principal es conservar y restaurar los corredores ecológicos, así como partes importantes de la diversidad biológica de la Mata Atlántica.

\footnotetext{
${ }^{4}$ UNESCO, Organización de las Naciones Unidas para la Educación, la Ciencia y la Cultura. Disponible en: http://www.unesco.org (fecha de consulta: marzo de 2018).

${ }^{5}$ Demostrada en la sección 3.2.3.
} 


\subsubsection{Río+20}

La Conferencia de las Naciones Unidas sobre el Desarrollo Sostenible, conocida por el evento Río+20 (Rio de janeiro, Brasil), se organizó veinte años después de la Cumbre de la Tierra de 1992, también en Rio de Janeiro. Se originó con el propósito de reducir la pobreza, fomentar la equidad social y garantizar la protección del medio ambiente en un planeta con una creciente demografía. La conferencia se centró en dos temas principales: cómo construir una economía ecológica para lograr el desarrollo sostenible y sacar a la gente de la pobreza, y cómo mejorar la coordinación internacional para el desarrollo sostenible.

En el evento se reconocieron las importantes contribuciones económicas, sociales y ambientales de los manglares. También se identificaron las vulnerabilidades a efectos como los producidos por el cambio climático, la acidificación de los océanos, la pesca excesiva, las prácticas pesqueras destructivas y la contaminación. Como objetivo destinado a los manglares, descripto en su documento final ${ }^{6}$, busca la cooperación internacional para conservar el ecosistema y lograr sus ventajas sociales, económicas y ambientales, así como facilitar la colaboración técnica y el intercambio voluntario de información.

\subsubsection{Agenda 2030}

En 2015, la Asamblea General de las Naciones Unidas aprobó la Agenda 2030 para el Desarrollo Sostenible ${ }^{7}$. Esta resolución complementan los Objetivos del Desarrollo del Milenio elaborados en el año de 2000 para 2015, con propuestas más amplias y desafiadoras. Consiste en un plan de acción para las personas, el planeta, la prosperidad, la paz y las alianzas. Son al total 17 objetivos y 169 metas para 2030, que buscan erradicar la pobreza y el hambre, proteger el planeta contra la degradación, así como las medidas contra el cambio climático, y promover la prosperidad en armonía con la naturaleza.

La Agenda 2030 defiende la protección de los ecosistemas terrestres y de los ecosistemas relacionados con el agua, como el de los manglares. Entre los objetivos propuestos, se debe proteger, restablecer y promover su uso sostenible; detener la deforestación y recuperar los bosques degradados; adoptar medidas urgentes para reducir la degradación y la perdida de la biodiversidad; adoptar medidas para prevenir la introducción de especies exóticas

\footnotetext{
${ }^{6}$ Río+20, Conferencia de las Naciones Unidas sobre el Desarrollo Sostenible. Documento final. Disponible en https://rio20.un.org/sites/rio20.un.org/files/a-conf.216-l-1_spanish.pdf.pdf (fecha de consulta: marzo de 2018).

${ }^{7}$ Agenda 2030 para el Desarrollo Sostenible. Resolución aprobada por la Asamblea General el 25 de septiembre de 2015. Disponible en http://www.un.org/es/comun/docs/?symbol=A/RES/70/1 (fecha de consulta: junio de 2018).
} 
invasoras; y movilizar recursos para la gestión forestal y proporcionar incentivos adecuados a los países en desarrollo para la conservación y reforestación. El último enfoque es muy importante, una vez que los manglares se sitúan principalmente en los países en desarrollo, como el ejemplo de Brasil.

\title{
4.2 ÁMBITO NACIONAL
}

En Brasil hay básicamente cinco leyes vigentes que protegen los manglares en la escala territorial. A continuación se analizan las leyes del Código Forestal, la Constitución Federal, el Plan Nacional de Gestión Costera, el Sistema Nacional de Unidades de Conservación y el Consejo Nacional del Medio Ambiente.

\subsubsection{Código Forestal}

La Ley del Código Forestal n 4.771/1965 (alterada por la Ley n 12.651/2012) ${ }^{8}$, establece las normas generales relativas a la protección de la vegetación, Áreas de Preservación Permanente y Áreas de Reserva Legal.

Los manglares fueron determinados como Áreas de Preservación Permanente en toda su extensión. En esta ley, los manglares se definen como:

\begin{abstract}
Ecosistema costero que se desarrollan en terrenos bajos, sujetos a la acción de las mareas, formados por suelos lodosos recientes o arenosos, a las que se asocian, predominantemente, a la vegetación natural conocida como manglar, con influencia fluviomarina, típica de suelos limosos de regiones estuarias y con dispersión discontinua a lo largo de la costa brasileña, entre los Estados de Amapá y de Santa Catarina (Brasil, 2012, Cap. I, Art. $3^{\circ}$ ).
\end{abstract}

En cuanto a las Áreas de Preservación Permanente, están consideradas como:

Áreas cubiertas o no por vegetación nativa, con la función ambiental de preservar los recursos hídricos, el paisaje, la estabilidad geológica y la biodiversidad, facilitar el flujo de genes de la fauna y la flora, la protección del suelo y garantizar el bienestar de las poblaciones humanas (Brasil, 2012, Cap. I, Art. $3^{\circ}$ ).

Sin embargo, según esta ley, la vegetación de manglar en los lugares donde su función ecológica está comprometida podrá sufrir intervenciones para la construcción de obras habitacionales, en la que estén incluidas en proyectos de interés social con ocupación de

\footnotetext{
${ }^{8}$ Brasil (2012). Lei do Código Florestal n 12.651 . Dispõe sobre a proteção da vegetação nativa.
} 
población de baja renta (Brasil, 2012, Cap. 2, Sección II, Art. $8^{\circ}$ ). En este caso, la dominación pública provoca que estas áreas de manglares, además de fragilizadas, se vuelvan mucho más débiles, acentuando en mayor grado la pérdida y fragmentación de este ecosistema.

\subsubsection{Constitución Federal y Plan Nacional de Gestión Costera (PNGC)}

La Constitución Federal de $1988^{9}$ establece las normas sobre el medio ambiente, de acuerdo con siguiente cita:

Todos tienen derecho al medio ambiente ecológicamente equilibrado, bien de uso común de la población y esencial a la sana calidad de vida, imponiéndose al Poder Público y a la colectividad el deber de defenderlo y preservarlo para las presentes y futuras generaciones (Brasil, 1988, Cap. V, Art. 225).

Según las dichas normas, la Constitución Federal considera las siguientes zonas a ser protegidas:

El Bosque Amazónico brasileño, la Mata Atlántica, la Serra do Mar, el Pantanal Mato-Grossense y la Zona Costera son patrimonio nacional, y su utilización se hará, en la forma de la ley, dentro de condiciones que aseguren la preservación del medio ambiente, incluso en cuanto al uso de los recursos naturales (Brasil, 1988, Cap. V, Art. 225).

En este contexto, el manglar es un ecosistema protegido, pues es parte de la zona costera. Conforme el Plan Nacional de Gestión Costera (PNGC) ${ }^{10}$, se considera zona costera el espacio geográfico de interacción del aire, del mar y de la tierra, incluyendo sus recursos renovables o no, que abarca una franja marítima y otra terrestre. Según el Artículo $3^{\circ}$, esta ley prevé la zonificación de los usos y actividades en estas áreas, priorizando la conservación y protección natural, en la cual incluye los manglares.

\subsubsection{Sistema Nacional de Unidades de Conservación (SNUC)}

El Sistema Nacional de Unidades de Conservación de la Naturaleza (SNUC), Ley $n^{\circ}$ 9.985/2000 ${ }^{11}$, establece los criterios y normas para la creación, implementación y gestión de áreas protegidas (incluyendo los manglares). Es constituido por el conjunto de las Unidades de Conservación Federales, Estatales y Municipales. Según esta ley, la Unidad de

\footnotetext{
${ }^{9}$ Brasil (1988). Constituição da República Federativa do Brasil.

${ }^{10}$ Brasil (1988). Lei $n^{\circ}$ 7.661. Institui o Plano Nacional de Gerenciamento Costeiro e dá outras providências.

11 Brasil (2000). Lei n 9.985. institui o Sistema Nacional de Unidades de Conservação da Natureza e dá outras providências.
} 
Conservación significa:

\begin{abstract}
Espacio territorial y sus recursos ambientales, incluyendo las aguas jurisdiccionales, con características naturales relevantes, legalmente instituido por el Poder Público, con objetivos de conservación y límites definidos, bajo régimen especial de administración, al que se aplican garantías adecuadas de protección (Brasil, 2000, Cap. I, Art. $2^{\circ}$ ).
\end{abstract}

EI SNUC se divide en dos grupos. El primer grupo, Unidades de Protección Integral, tiene como objetivo preservar la naturaleza, siendo admitido sólo el uso indirecto de sus recursos naturales. Son parte de este grupo las siguientes Unidades de Conservación: Estación Ecológica, Reserva Biológica, Parque Nacional, Monumento Natural y Refugio de Vida Silvestre.

El segundo grupo, Unidades de Uso Sostenible, tiene como objetivo compatibilizar la conservación de la naturaleza con el uso sostenible de sus recursos naturales. Son parte de este grupo las siguientes Unidades de Conservación: Área de Protección Ambiental, Área de Relevante Interés Ecológico, Bosque Nacional, Reserva Extractiva, Reserva de Fauna, Reserva de Desarrollo Sostenible y Reserva Particular del Patrimonio Natural.

En cuanto a los manglares del territorio brasileño, algunos de ellos están protegidos por Unidades de Conservación. Las Unidades y sus respectivos objetivos son los siguientes:

1. Estación Ecológica: su objetivo es la preservación de la naturaleza y la realización de investigaciones científicas.

2. Reserva Biológica: tiene como meta la preservación integral de la biodiversidad y los demás atributos naturales existentes en sus límites, sin interferencia humana directa o modificaciones ambientales.

3. Parque Nacional: tiene como objetivo la preservación de los ecosistemas naturales de gran relevancia ecológica y belleza escénica, posibilitando la realización de investigaciones científicas y el desarrollo de actividades de educación e interpretación ambiental, de recreación en contacto con la naturaleza y del turismo ecológico.

4. Área de Protección Ambiental: tiene como objetivo la protección de la biodiversidad, limitar el proceso de ocupación y asegurar la sostenibilidad del uso de los recursos naturales.

5. Área de Relevante Interés Ecológico: su objetivo es mantener los ecosistemas naturales de importancia regional o local y monitorear el uso admisible de estas áreas. 
6. Bosque Nacional: tiene como objetivo el uso múltiple sostenible de los recursos forestales y la investigación científica.

7. Reserva Extractiva: tiene como finalidad proteger los medios de vida y la cultura de las poblaciones, y asegurar el uso sostenible de los recursos naturales.

8. Reserva Particular del Patrimonio Natural: tiene como objetivo conservar la diversidad biológica.

Es importante resaltar también que las Unidades de Conservación deben tener zonas de amortiguaciones y corredores ecológicos, incluyendo medidas con el fin de promover su integración en la vida económica y social de las comunidades vecinas (Brasil, 2000, Cap. IV, Art. $27^{\circ}$ ). La ley caracteriza las zonas de amortiguaciones como: "el entorno de una unidad de conservación, donde las actividades humanas están sujetas a normas y restricciones específicas, con el propósito de minimizar los impactos negativos de la Unidad" (Brasil, 2000, Cap. I, Art. $2^{\circ}$ ). En cuanto a los corredores ecológicos, se definen como:

Porciones de ecosistemas naturales o seminaturales que unen las unidades de conservación, que posibilitan entre ellas el flujo de genes y el movimiento de la biodiversidad, facilitando la dispersión de especies y la recolonización de áreas degradadas, así como el mantenimiento de poblaciones que necesitan para su supervivencia áreas con una extensión mayor que la de las unidades individuales (Brasil, 2000, Cap. I, Art. $2^{\circ}$ ).

El establecimiento de zonas de amortiguaciones y principalmente de corredores ecológicos es considerado fundamental para el mantenimiento de la biodiversidad tanto de los manglares como la vegetación de su entorno, pues de esta forma potencia sus servicios ecosistémicos.

\subsubsection{Consejo Nacional del Medio Ambiente (Conama)}

En esta sección son de importancia las resoluciones del Consejo Nacional del Medio Ambiente (Conama) $n^{\circ} 303 / 2002^{12}$ y $n^{\circ} 369 / 2006^{13}$, pues consideran, entre otros, reglamentar el Código Forestal. La primera tiene la función de ordenar los parámetros, definiciones y límites de las Áreas de Preservación Permanente. Como los manglares se incluyen en estas áreas, están dentro de esta resolución.

12 Brasil (2002). Conselho Nacional do Meio Ambiente. Ministério do Meio Ambiente (Conama), Resolução $n^{\circ}$ 303/2002. Dispõe sobre parâmetros, definições e limites de Áreas de Preservação Permanente.

13 Brasil (2006). Conselho Nacional do Meio Ambiente. Ministério do Meio Ambiente (Conama), Resolução $n^{\circ}$ 369/2006. Dispõe sobre os casos excepcionais, de utilidade pública, interesse social ou baixo impacto ambiental, que possibilitam a intervenção ou supressão de vegetação em Área de Preservação Permanente-APP. 
La segunda define los casos excepcionales de intervención o supresión de la vegetación en las Áreas de Preservación Permanente. En esta resolución, se permiten las intervenciones en los manglares en los casos de utilidad pública. Las actividades consideradas de uso público son las siguientes:

\begin{abstract}
Las actividades de seguridad nacional y protección sanitaria; las obras esenciales de infraestructura destinadas a los servicios públicos de transporte, saneamiento y energía; las actividades de investigación y extracción de sustancias minerales, otorgadas por la autoridad competente, excepto arena, arcilla, tierra batida y grava; la implantación de área verde pública en área urbana; investigación arqueológica; obras públicas para implantación de instalaciones necesarias para la captación y conducción de agua y de efluentes tratados; e implantación de instalaciones necesarias para la captación y conducción de agua y de efluentes tratados para proyectos privados de acuicultura, obedecidos los criterios y requisitos previstos en los $\S \S 1^{\circ}$ y $2^{\circ}$ del Art. 11, de esta Resolución (Brasil, 2006, Sección I, Art. $2^{\circ}$ ).
\end{abstract}

Sin embargo, estas intervenciones pueden afectar al ecosistema, principalmente en lo que dice respecto a las obras de infraestructura para el transporte, saneamiento y la acuicultura, descriptas en esta resolución.

\title{
4.3 ÁMBITO MUNICIPAL
}

La mayoría de las ciudades brasileñas tienen herramientas de planificación que influyen en la cantidad y calidad de los espacios naturales, como los Planes Directores que tienen en cuenta las leyes nacionales. EI Plan Director es una estrategia para la ordenación del espacio urbano, garantizando el bienestar de la población municipal. Tiene como reto principal el proceso del desarrollo local, a partir de los factores políticos, económicos, culturales, ambientales, institucionales, sociales y territoriales.

Según la Ley $n^{\circ} 10.257 / 2001$ del Estatuto de la Ciudad ${ }^{14}$, reglamenta, a través del Artículo $182^{\circ}$, que la política de desarrollo urbano ejecutada por el gobierno municipal tiene como objetivo establecer normas de orden pública e interés social, que regulan el uso de la propiedad urbana a favor del bien colectivo, la seguridad, el bienestar de los ciudadanos y el equilibrio del medio ambiente.

En este estudio, se tomará como base la ley vigente del Plan Director del Municipio de

\footnotetext{
${ }^{14}$ Brasil (2001). Lei do Estatuto da Cidade n 10.257. Regulamenta os arts. 182 e 183 da Constituição Federal,
} estabelece diretrizes gerais da política urbana e dá outras providências. 
Florianópolis ${ }^{15}$, que abarca esta investigación. Existen básicamente dos categorías para la conservación de la biodiversidad, donde se insertan los manglares, como las Áreas de Preservación Permanente y las Unidades de Conservación.

Las Áreas de Preservación Permanente municipales protegen los manglares tanto en su extensión, como las áreas adyacentes a los manglares que tienen influencia salina de las mareas y/o vegetación característica de transición entre los manglares y los suelos secos (Florianópolis, 2014, Cap. II, Sección I, Art. 43). Están protegidas a través de la ley nacional del Código Forestal y reglamentadas por el Consejo Nacional del Medio Ambiente (Conama).

En cuanto a las Unidades de Conservación, éstas dependen de la finalidad de cada manglar, diferenciándolos como Unidades de Protección Integral o Unidades de Uso Sostenible. Están protegidos por el Sistema Nacional de Unidades de Conservación de la Naturaleza (SNUC). En el Municipio de Florianópolis existen cuatro manglares protegidos por este sistema, identificados como Río Ratones, Saco Grande, Itacorubi y Río Tavares, caracterizados a través de las siguientes Unidades:

1. Los manglares del Río Ratones y de Saco Grande pertenecen a la Unidad de Conservación Estación Ecológica Carijós, destinada a la preservación de la naturaleza y la realización de investigaciones científicas.

2. El manglar de Itacorubi pertenece a la Unidad de Conservación Parque del Manglar de Itacorubi, destinada a la preservación de la naturaleza, la realización de investigaciones científicas y el desarrollo de actividades de educación, recreación y del turismo ecológico.

3. El manglar del Río Tavares pertenece a la Unidad de Conservación Reserva Extractiva Marina Pirajubaé, destinada a proteger los medios de vida y la cultura de las poblaciones, y asegurar el uso sostenible de los recursos naturales.

Rio Ratones, Saco Grande e Itacorubi están incluidos en el grupo de las Unidades de Protección Integral, que además de preservar la naturaleza, se los pueden utilizar de forma indirecta sus recursos naturales. En cuanto a Río Tavares, está en el grupo de las Unidades de Uso Sostenible, que integra la conservación de la naturaleza con el uso sostenible de sus recursos naturales.

Sin embargo, no todos los manglares están protegidos por estas Unidades. En Florianópolis,

15 Florianópolis (2014). Lei Complementar $n^{\circ}$ 482. Institui o Plano Diretor de urbanismo do Município de Florianópolis que dispõe sobre a política de desenvolvimento urbano, o plano de uso e ocupação, os instrumentos urbanísticos e o sistema de gestão. Diário Oficial, Prefeitura Municipal de Florianópolis. 
de un total de cinco manglares, cuatro están protegidos. En los municipios vecinos que conforman la Región Metropolitana de Florianópolis, existen cuatro manglares y ninguno de ellos está protegido bajo este sistema, necesitando de Unidades de Conservación específica para estas áreas. Esto se verifica como una situación de alarma, pues uno de los puntos claves de esta legislación, además de la creación, implementación y gestión de áreas protegidas, es la importancia de incluir corredores ecológicos entre estas zonas. De esta forma, posibilita el flujo de genes de las especies, fundamentales para el mantenimiento de la biodiversidad de los manglares y de la vegetación adyacente, para que puedan proporcionar sus servicios ecosistémicos. 


\section{CONECTIVIDAD ECOLÓGICA}

La conectividad ecológica hace referencia a las redes continuas naturales o ecológicas que albergan múltiples escalas y tipos de ecosistemas, con la capacidad de lograr variados beneficios sostenibles en el territorio. Es un concepto que permite investigar de qué manera la interacción entre la estructura del paisaje y el movimiento de las especies afecta la supervivencia de las mismas, el flujo de genes y otros procesos ecológicos, clave en los paisajes fragmentados (Luque et al., 2012). Según esta afirmación y de acuerdo con Taylor et al. (1993), la conectividad se verifica a través del grado en que el paisaje facilita o impide el movimiento de las especies entre los hábitats. Existe, por lo tanto, una relación directa entre estructura y función (Burel y Baudry, 1999), donde la forma del paisaje condiciona el comportamiento de los individuos, dificultando su proceso en los paisajes perjudicados por los factores antropogénicos.

Es, por lo tanto, a través del mantenimiento de la conectividad ecológica en los paisajes que se conserva la biodiversidad para que se pueda ejercer sus beneficios ecosistémicos. Según Rapport (2005), la diversidad biológica es uno de los indicadores considerados más importantes respecto a la salud de un ecosistema. En este aspecto, y de gran relevancia para este estudio, es de extrema importancia la conectividad ecológica en el ecosistema de los manglares entre sí y con las otras vegetaciones circundantes, una vez que los manglares son considerados como un área de transición en la migración de las especies venidas de otros ecosistemas.

La noción sobre la importancia de la conectividad ecológica se originó en la segunda mitad del siglo XIX, y aborda a una variedad de cuestiones que se pueden profundizar desde la perspectiva de la ecología del paisaje hasta la infraestructura verde, relacionándolos con su desarrollo en Brasil. Por lo tanto, este capítulo se destina a los estudios de la conectividad ecológica, divididos en cinco subcapítulos subsecuentes, que se distinguen en:

5.1 ANTECEDENTES: breve contexto histórico de la conectividad ecológica.

5.2 ECOLOGÍA DEL PAISAJE Y CONECTIVIDAD: conceptos de la conectividad ecológica en la ecología del paisaje.

5.3 INFRAESTRUCTURA VERDE Y CONECTIVIDAD: definiciones y estrategias de la conectividad ecológica en la infraestructura verde. 
PARTE II. Capítulo 5. CONECTIVIDAD ECOLÓGICA

5.5 CONTEXTO BRASILEÑO: explicación de la relación entre los espacios naturales y urbanos, y las conexiones verdes territoriales en Brasil. 


\subsection{ANTECEDENTES HISTÓRICOS}

Los conceptos, estrategias y aplicaciones sobre la conectividad ecológica tuvieron variados antecedentes históricos, que influenciaron a muchos autores desde la segunda mitad del siglo XIX. Este propósito fue una respuesta a los efectos negativos de la Revolución Industrial, donde se produjo un éxodo de la población rural hacia las zonas urbanas.

Proyectos como el Emerald Necklace (Frederick Law Olmsted, 1878) y las Ciudades Jardines de Howard (1898), estimularon los conceptos de conectividad ecológica en los espacios urbanos (Figuras 5.1 y 5.2). Los aspectos se diferenciaban en las conexiones lineales que conectan la ciudad y el campo (greenways) y los espacios naturales que rodean la ciudad, formando cinturones verdes (green belts). Las greenways y green belts, con sus múltiples funciones a través de conexiones de espacios naturales en los medios urbanos, se consideraron importantes para la evolución de los sistemas de redes verdes.

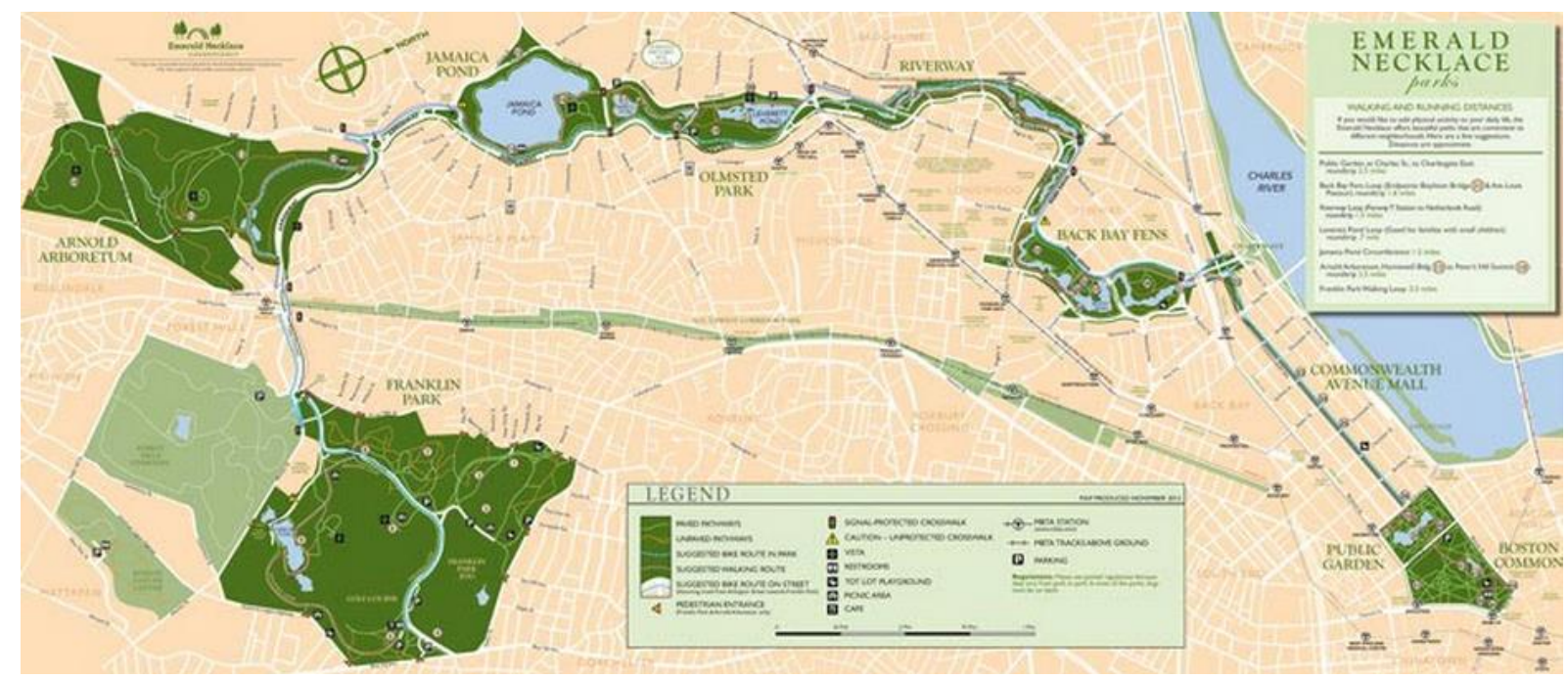

Figura 5.1: Emerald Necklace. Fuente: disponible en http://www.emeraldnecklace.org/ (fecha de consulta: marzo de 2015). 


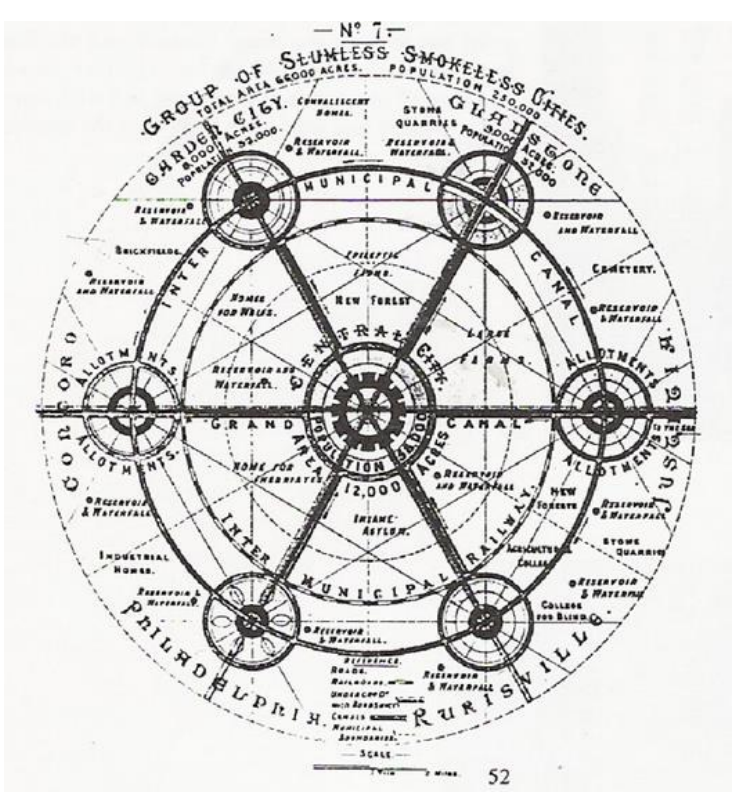

Figura 5.2: Ciudades Jardines. Fuente: Howard, 1898.

Con el aumento de la densidad urbana a partir de la década de 1960, la pérdida y fragmentación de los ecosistemas han ocurrido debido a los intensos cambios del uso del suelo. Este hecho interfirió en la dinámica natural, impidiendo la continuidad de las muchas especies de la fauna y flora. Por este motivo, empezaron grandes preocupaciones con la protección de los recursos naturales y surgieron distintas estrategias de la conectividad ecológica, que han servido de base para el planeamiento del uso del suelo en variadas escalas.

En 1964, Philip Lewis mapeó el Estado de Wisconsin, en EE.UU., e introdujo el concepto de corredor ambiental. Su proyecto implicó valores correspondientes al carácter ecológico, fisiográfico, histórico-cultural y atributos estéticos (Little, 1990). También fue importante al agregar los recursos naturales y culturales a lo largo de los ríos y de otras zonas lineales.

En 1969, lan McHarg publicó su libro Design with Nature, que fortaleció los planes para el desarrollo en grandes áreas, con la creación de una estructura espacial que concilia la conservación del medio ambiente y la expansión urbana y rural. El método se originó a partir del mapeo de las unidades fisiográficas (topografía, clima, tipos de suelo, drenaje, aguas superficiales y subterráneas, la susceptibilidad a la erosión o suelos fértiles), creando datos acerca del paisaje y el establecimiento de una zonificación previa, indicando los posibles usos del suelo. El estudio mostró que las áreas a lo largo de los ríos son los principales corredores que se deben proteger.

Forman y Godron (1986) publicaron el libro Landscape Ecology, sobre la ecología del paisaje, 
con principios fundamentales para el desarrollo del planeamiento ecológico. Ellos propusieron el estudio del paisaje a través del mosaico territorial, formado por los elementos espaciales de matriz, manchas y corredores. Según Forman (1995), estos elementos pueden ser diversificados, naturales o culturales, de diferentes ecosistemas y tipos de ocupación del suelo.

Finalmente, en 2006, Benedict y McMahon estimularon, a través del libro Green Infrastructure, los conceptos más actuales sobre la conectividad ecológica. Mediante una red interconectada se valora el ecosistema natural, mientras se benefician la vida humana. Se estructura a partir de un concepto sostenible, que mantiene los beneficios ambientales, sociales y económicos del territorio.

A lo largo de la historia se ha verificado que la naturaleza siempre se ha enfrentado a un reto común: su relación con la ocupación humana. Sin embargo, los estudios sobre la conectividad ecológica agregan características de funcionalidad para estos espacios, que se benefician en los aspectos ambientales, sociales, culturales y económicos en diversos ámbitos escalares. Entre los distintos métodos existentes, tanto los estudios de la ecología del paisaje, como de la infraestructura verde, son fundamentales para el planeamiento actual, a través de diseños y técnicas innovadoras sencillas para la protección, manutención y creación de los espacios naturales.

\subsection{ECOLOGÍA DEL PAISAJE Y CONECTIVIDAD}

La expresión ecología del paisaje fue utilizada por primera vez por el biogeógrafo Alemán Carl Troll a finales de la década de 1930. El estudio vinculó las estructuras espaciales, que son el objeto de la geografía, con los procesos ecológicos (Burel y Baudry, 1999, p. 6). Más tarde, a partir de la década de 1980 este principio se reforzó a través de la estructuración y definición de los componentes del paisaje, como los estudios de Forman y Godron (1986), con el objetivo de facilitar la planificación ecológica de un territorio, buscando reducir la fragmentación y la degradación ambiental. En los últimos años, a través del incentivo multidisciplinar y tecnologías, han ocurrido grandes avances en la investigación a través del desarrollo de métodos cuantitativos, que lleva en cuenta la fragmentación de los hábitats y la conectividad ecológica en los paisajes para la conservación de la biodiversidad.

Básicamente, la ecología del paisaje se organiza a través de la estructura, la funcionalidad y el cambio. La estructura es el resultado de la configuración espacial de los elementos de 
paisaje. Está relacionada con la funcionalidad, donde controla fuertemente todos los movimientos y flujos de animales, plantas, agua, viento, materiales y energía, y provoca cambios en las poblaciones en diversas escalas a lo largo del tiempo (Dramstad et al., 1996, p. 17). Según Forman y Godron (1986), la estructura se genera a través de los componentes del mosaico territorial, formado por la matriz, manchas y corredores. Estos principios son aplicables tanto para áreas naturales como para áreas con intensa actividad humana (Dramstad et al., 1996, p. 16), en el ámbito local y también en mosaicos regionales (Dramstad et al., 1996, p. 19).

Las manchas se refieren a los fragmentos del paisaje, determinadas por unidades homogéneas, como los bosques, áreas urbanas o rurales. Los corredores son las conexiones existentes entre las manchas, con características lineales, facilitando el desplazamiento de las especies entre los fragmentos de hábitat o funcionando como barrera, limitando el movimiento. Finalmente, la matriz está formada por el conjunto de los fragmentos y corredores.

La cantidad, tamaño, distribución y forma de los fragmentos y corredores en la matriz varía, determinando diversos niveles y tipos de conectividades. El análisis debe considerar todos los fragmentos como posibles corredores de mayor o menor eficacia (Español Echániz, 2006, p. 100). Es el grado de conectividad que establece la salud ecológica en el paisaje, donde la forma espacial del territorio tiene el potencial de facilitar o inhibir el desplazamiento de las especies.

En general, el grado de conectividad depende de la interrelación de los factores naturales y humanos que componen un determinado paisaje, demostrando una matriz más heterogénea u homogénea. El proceso de pérdida y aislamiento de los ecosistemas promovidos por los factores antropogénicos, debilita los flujos ecológicos y acentúa la necesidad de proveer la conectividad para el mantenimiento de las especies. Es importante mencionar que para maximizar la protección de la biodiversidad y los procesos naturales en la planificación, la identificación de los aspectos que estructuran un paisaje se hace mediante los análisis en distintas escalas (Dramstad et al., 1996, p. 47).

Los estudios iniciales de la ecología del paisaje estuvieron marcados por una importante producción de índices para medir las estructuras del paisaje y determinar su conectividad. El problema principal con tales medidas es el intento de reducir una estructura espacial a un número, donde se pierde una gran cantidad de información, especialmente en el cálculo de promedios (Burel y Baudry, 1999, p. 68 y 69). 
Recientemente, la investigación ha implicado métodos que estudian el comportamiento de los animales a través de un determinado paisaje, con distintas nuevas medidas para cuantificarlo. Estos métodos agregan, además del conocimiento de la estructura del paisaje, el movimiento de las especies a través de ella. De esta manera, se determina la importancia de las dimensiones estructurales (forma espacial) y funcionales (desplazamiento de las especies) para los análisis del paisaje. Actualmente, este proceso es facilitado por el uso de los sistemas de información geográfica, que permite gestionar la información espacial y aplicarlo a diversas escalas.

\title{
5.3 INFRAESTRUCTURA VERDE Y CONECTIVIDAD
}

El término infraestructura verde hace referencia a los enfoques y conceptos relacionados con la componente ambiental, donde hay una preocupación de contribución sostenible en la planificación territorial. De acuerdo con la Comisión Europea (CE, 2014), a través de una estructura ecológica conectada, la infraestructura verde tiene el objetivo de potencializar el funcionamiento de la naturaleza para mejorar la calidad de vida, la biodiversidad, la protección del cambio climático y otras catástrofes medioambientales, con enfoque inteligente e integrado.

Según Benedict y McMahon (2006, p. 3), la infraestructura verde se refiere a una red espacial verde interconectada, que se planifica y gestiona a través de sus recursos naturales y beneficios generados a las poblaciones humanas, utilizada en la escala nacional, estatal, regional y local.

En cuanto a las políticas de la Unión Europea ${ }^{16}$, se entiende infraestructura verde como:

\begin{abstract}
Una red estratégicamente planificada de espacios naturales y seminaturales y otros elementos ambientales diseñados y gestionados para ofrecer una amplia gama de servicios ecosistémicos. Incorpora espacios verdes (o azules en el caso de los ecosistemas acuáticos) y otros elementos físicos de espacios terrestres (incluidas las zonas costeras) y marinos. En los espacios terrestres, la infraestructura verde está presente en los entornos rurales y urbanos (Unión Europea, 2013).
\end{abstract}

Esta estrategia tiene la finalidad de promover su uso en toda Europa, en los ámbitos nacionales, regionales y municipales. Está integrada en los procesos de planificación y ordenación del territorio, que conectan los espacios conformados por la red Natura 2000,

\footnotetext{
16 Unión Europea (2013). Comunicación de la comisión al parlamento europeo, al consejo, al comité económico y
} social europeo y al comité de las regiones. Infraestructura verde: mejora del capital natural de Europa. Bruselas. 
reforzando la protección en estas zonas.

Por lo tanto, se puede definir básicamente en dos métodos fundamentales: la conectividad y la multifuncionalidad ecológica. La primera se relaciona con la parte estructural ambiental en red. La segunda, permite atender múltiples beneficios sostenibles a través de los servicios que proporcionan los ecosistemas.

Estos servicios están divididos en tres grandes grupos: abastecimiento, regulación y culturales (Fariña, 2013). Los servicios de abastecimiento contribuyen directamente para el bien estar humano, como los alimentos, el agua para el consumo humano y las materias primas. Los de regulación contribuyen de forma indirecta, como la regulación climática, el control de inundación y erosión, la calidad del aire, agua y suelo. Por último, los culturales, son las experiencias directas que las poblaciones tienen con los ecosistemas, como el conocimiento ambiental local, el disfrute ecológico y la identidad cultural.

A partir de los beneficios generados por los servicios ecosistémicos, la infraestructura verde actúa como una estrategia a los efectos de las pérdidas ambientales debido al cambio del uso del suelo. Consta de intervenciones de alto rendimiento en el paisaje, proporcionando el apoyo para la resiliencia ambiental. Se presenta en variados niveles territoriales, desde la escala macro hasta la micro, en diversos contextos regionales y urbanos. Todos los elementos ecológicos pueden consistir en una infraestructura verde, sin embargo, en cada escala hay distintas necesidades y posibilidades de actuación, que se conciben de una manera diferente en cada dimensión.

En la escala regional, la infraestructura verde se desarrolla a través de las conexiones verdes que integran los espacios protegidos de alto valor ecológico, como los bosques y los ríos, siendo fundamental para restaurar las dinámicas naturales de los ecosistemas. Según Dramstad et al. (1996, p. 39), los ríos son estructuras de conectividad muy importantes para incluir en la planificación, por el uso intensivo que proporcionan estos sistemas. Sin embargo, los corredores artificiales en el paisaje pueden actuar como una barrera o filtro para el movimiento de las especies (Dramstad et al., 1996, p. 39). Ejemplos como las vías de carreteras, ferrocarriles, líneas eléctricas, entre otros, pueden aislar completamente una población de especies, llevando a un riesgo de extinción. Aunque, algunas estrategias como los ecoductos o puentes verdes, pueden favorecer la movilidad de las especies.

Los espacios naturales en la escala urbana constituyen parte de la infraestructura verde al integrarse entre sí. Corresponden esencialmente a los locales de permanencia y movilidad, tal como las plazas ajardinadas, parques urbanos, jardines y alamedas. Asimismo, otros 
elementos presentes en los medios urbanos pueden ser integrados en la infraestructura verde para mejorar el desempeño sostenible en estas áreas, tales como: la utilización de suelo permeable, que contribuye para la facilidad de drenaje urbano; vegetación en llanuras aluviales y marismas para la prevención de inundaciones; talud verde, que impide el deslizamiento de la tierra; cubierta y fachada verde para el aislamiento térmico, regulación de la humedad y atractivo visual.

Además de la utilización vegetal, la infraestructura verde también tiene como objetivo buscar oportunidades de transportes alternativos no contaminantes, como el uso de bicicletas, patines, incentivar el desplazamiento a pie y promover el uso de energías renovables, siempre que sea posible.

Conforme Fariña (2000), para plantear el diseño de la naturaleza en el medio urbano es necesario considerar cuatro principios fundamentales: los procesos de la naturaleza como algo dinámico que dependen de la intensidad circulatoria peatonal o de las lluvias; la economía de medios, aprovechando los beneficios ambientales y reduciendo en consumo de energía y materiales; la diversidad con la introducción de espacios libres verdes en las ciudades; y la importancia de la conexión de estos espacios para la protección de ecotopos en las ciudades.

De esta manera, la configuración de una red verde y su integración en el planeamiento urbanístico exige, en muchos casos, replantear la forma urbana tradicional en relación a sus áreas verdes. Aunque, hay que tener en cuenta que cada situación geográfica tendrá un urbanismo característico y diferenciado de otros lugares, siendo indispensable una planificación adecuada a las condiciones del clima y territorio (Higueras García, 2006, p. 15).

Sin embargo, de una forma general, hay que considerar que los paisajes son dinámicos y cambian conforme al tiempo, dependiendo del crecimiento y desarrollo de las ciudades. Para proporcionar una planificación y gestión sostenible, deben ser analizados los cambios del uso del suelo a través de la relación urbana con el territorio circundante (Díaz-Palacios-Sisternes et al., 2014). Estos análisis deben ser incorporados en los proyectos de la infraestructura verde, además de acompañamiento y atención proyectual, tanto en la organización del espacio, de acuerdo a sus usos y funciones, así como su mantenimiento.

Los criterios utilizados de la infraestructura verde han motivado a diversas ciudades para su implantación. Hay variados ejemplos de proyectos principalmente en Europa y Estados Unidos, tal como Vitoria-Gasteiz, Estocolmo, Londres, Hamburgo, Chicago y Portland. Todos ellos poseen semejanzas en sus políticas de planificación paisajística sobre las estrategias de conectividad y multifuncionalidad ecológica. Se han comprobado en estos lugares la 
resiliencia ambiental a partir de un territorio más habitable y sostenible y con alta calidad de vida.

\subsection{CONTEXTO BRASILEÑO}

Este subcapítulo aborda las cuestiones sobre la conectividad ecológica en Brasil en relación a la integración de sus espacios naturales y urbanos a lo largo de su historia, y respecto a sus conexiones verdes territoriales.

\subsubsection{La relación entre los espacios naturales y urbanos}

En los primeros siglos después del descubrimiento de Brasil, los habitantes no se preocupaban en planificar un paisaje natural para la recreación, pues el territorio ya lo ofrecía. El país siempre tuvo diversas posibilidades de ocio con sus recursos naturales a través de ecosistemas diversificados, lagunas, ríos, arroyos, etc. La naturaleza brasileña era una fuente de admiración a todos los viajeros que se fueron al territorio por ocio, curiosidad o en busca de nuevas especies de la flora (Terra, 2000).

La estructura de las áreas verdes urbanas en Brasil comenzó a surgir a finales del siglo XVIII. Estos espacios fueron creados solamente como una figura complementaria, un escenario para las élites emergentes, buscando construir un estilo urbanístico que era compatible con los jardines ingleses y franceses (Macedo y Sakata, 2003). En este momento estaban afiliados a la cultura europea gracias a la presencia de extranjeros en el país desde el siglo XVII, entre los cuales, holandeses, franceses e ingleses (Silva, 2011), que llevaron a cabo la apertura política y económica tanto en Inglaterra, como en Francia, simultáneamente.

Durante el siglo XIX hubo el momento de estructuración de Brasil como nación, con la llegada de la Familia Real Portuguesa en 1808. La Capital de Portugal se trasladó a Río de Janeiro y la ciudad pasó por rápidas transformaciones urbanas, creando los primeros espacios verdes públicos, como el Paseo Público, el Jardín Botánico y el Campo de Santana (Macedo y Sakata, 2003).

En el período Republicano (a partir de 1889), ocurrió una renovación urbana en las grandes ciudades como São Paulo y Rio de Janeiro. Los nuevos espacios con vegetación en línea surgieron entre el período de 1889 y 1920 . Algunas áreas de la costa de Río de Janeiro (como ejemplo, el Trecho da Gloria, diseñado por Paul Villon) fueron utilizadas por la población local para el baño, la recreación, el picnic y el deporte, a partir de un proceso de saneamiento y 
valorización de la costa.

En los años de 1940, los trazados de la época modernista influenciaron las obras de Roberto Burle Marx. La introducción de este concepto en Rio de Janeiro se asoció con la construcción de un nuevo paisaje, a partir de la geometría libre y la utilización de especies nativas para la preservación de la flora brasileña, con soluciones paisajísticas para el beneficio de los ciudadanos a través de rutas a pie, bicicleta y práctica de deportes.

Este concepto sucedió a partir de grandes intervenciones urbanas, principalmente la ejecución de terraplenes en las costas (como ejemplo, el parque de Flamengo, conocido popularmente como Aterro do Flamengo, con un corredor verde de 120 hectáreas en la costa). Los terraplenes han ocupado las zonas de la costa de las ciudades brasileñas hacia el mar, donde aún hoy es una práctica muy común en las ciudades costeras en crecimiento. Según Macedo y Sakata (2003), la caracterización de playas o lagos como espacio libre urbano se tornaron como una entidad propia del país hasta la actualidad, por su inmensa costa para el Atlántico. Sin embargo, muchas veces, no se utilizaron espacios vegetados.

En las décadas de 1950 y 1960 hubo una creciente urbanización nacional que llevó a la población a vivir en las ciudades. Como consecuencia, se crearon nuevos espacios para algunas ciudades: la estructura morfológica se simplificó radicalmente, el deporte y ocio cultural se valoraron y aumentó el uso del coche, abandonando la estructura antigua y adoptando los principios modernistas de la Carta de Atenas (Macedo y Sakata, 2003). Brasilia se convirtió en el modelo de paisaje como ciudad-parque en la década de 1960, que integra el verde a la zona urbana, con el concepto de Lúcio Costa.

En cuanto a Curitiba, fue un caso inédito, con una política pública proyectada por Jaime Lerner de inversión en transporte, equipamientos urbanos y espacios verdes. La ciudad se estructuró a partir de 1966, permaneciendo en todas las administraciones posteriores y transformando las zonas urbanas en áreas vegetadas.

Sin embargo, a partir de la década de 1990, la sensibilización gubernamental y poblacional respecto a los espacios verdes ha estado lejos de ser deseable. Este evento fue impulsado por la construcción inmobiliaria en expansión, transformando paisajes, cambiando la jerarquía y la organización de los espacios públicos y privados (Macedo, 2001). Los impactos ambientales generados por la deforestación, contaminación, inundación, erosión, entre otros, son agravantes reales, donde la vegetación se convierte en una cuestión básica nacional. 


\subsubsection{Conexiones verdes territoriales}

Casi un tercio de los bosques tropicales existentes en el mundo se ubican en Brasil, siendo reconocido como uno de los más importantes repositorios de la diversidad biológica. Los más reconocidos son Amazonia y Mata Atlántica. Desafortunadamente, estas áreas se han convertido rápidamente para otros usos. Las cifras oficiales indican que la deforestación ha afectado a cerca del $11 \%$ de la Amazonia y $92 \%$ de la Mata Atlántica (Ayres et al., 2005, p. 13). En Amazonia los problemas se originan principalmente de la extracción de la madera, minerales, agricultura y ganadería. La Mata Atlántica, ubicada en la costa brasileña, se muestra muy fragmentada por la ocupación de los grandes centros urbanos, con alta densidad poblacional, además de zonas agrícolas, ganaderas e industriales.

Sin embargo, fueron identificados en el territorio cinco tipos de corredores ecológicos en Amazonia y dos en la Mata Atlántica, según los estudios de Ayres et al. (2005). Estos corredores están sobrepuestos a las áreas de importancia ecológicas en las escalas continental y nacional para su conservación (determinadas como áreas prioritarias de conservación), demostrados en el siguiente mapa (Figura 5.3).

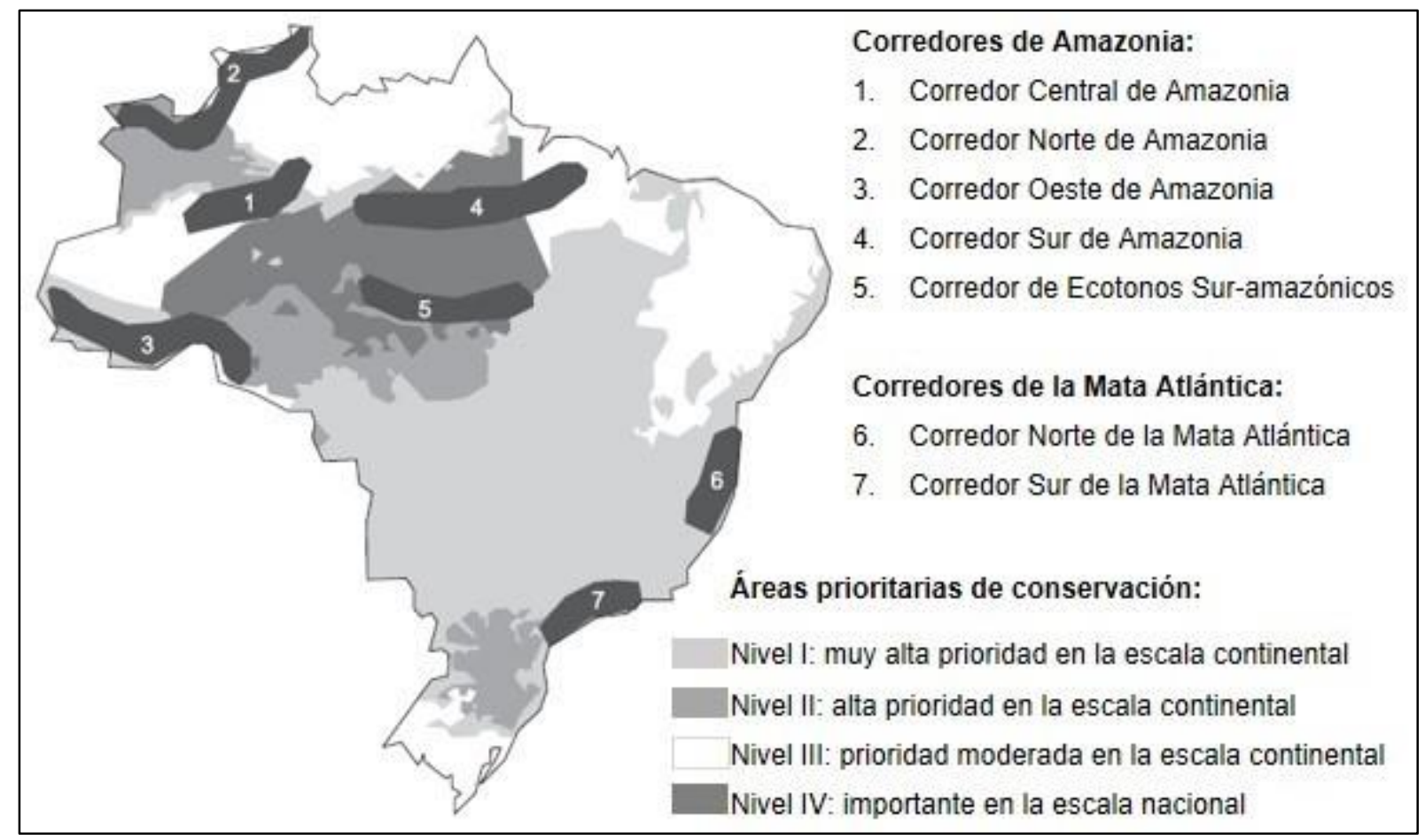

Figura 5.3: Corredores verdes en Brasil. Fuente: Ayres et al. (2005, p. 27).

La descripción de las áreas prioritarias de conservación son las siguientes: 
1. Nivel I: áreas de extraordinaria diversidad biológica en la escala continental, con altos niveles de endemismo, bajo alto grado de amenaza potencial o real, que están relativamente estables a lo largo de vastas extensiones de paisaje.

2. Nivel II: áreas de alta diversidad biológica en la escala continental y niveles considerables de endemismo, bajo alto grado de amenaza potencial o real, que están intactas o relativamente estables a lo largo de vastas extensiones de paisaje.

3. Nivel III: áreas biológicamente representativas en la escala continental, independientemente de su grado de amenaza potencial o real.

4. Nivel IV: áreas biológicamente relevantes en la escala nacional, que no están bajo alto grado de amenaza, representadas a lo largo de vastas extensiones de paisaje.

La descripción de los corredores ecológicos son los siguientes:

1. Corredor Central de Amazonia: identificado como intacto, relevante en importancia biológica y de alta prioridad de conservación en la escala continental.

2. Corredor Norte de Amazonia: identificado como relativamente intacto, relevante en importancia biológica y de alta prioridad de conservación en la escala continental.

3. Corredor Oeste de Amazonia: corredor estable, relevante en importancia biológica y de muy alta prioridad de conservación en la escala continental.

4. Corredor Sur de Amazonia: corredor vulnerable, importante a nivel nacional y de prioridad moderada de conservación en la escala continental.

5. Corredor de Ecotonos Sur-amazónicos: identificado como vulnerable a relativamente estable, relevante en importancia biológica y de alta a moderada prioridad de conservación en la escala continental.

6. Corredor Norte de la Mata Atlántica: corredor muy amenazado, cuenta con el mayor índice de diversidad de plantas vasculares en el mundo y abriga un gran número de animales endémicos, con muy alta prioridad de conservación en la escala continental. Se considera el área donde existe la mayor cantidad de remanentes de la Mata Atlántica en el Noreste.

7. Corredor Sur de la Mata Atlántica: corredor muy amenazado, con importantes áreas protegidas de tamaño considerable, con muy alta prioridad de conservación en la escala 
continental. Se considera el área donde existe la mayor cantidad de remanentes de la Mata Atlántica en los Estados de Rio de Janeiro, São Paulo y Paraná.

En Amazonia, los corredores Central, Norte y Oeste, se identificaron como muy alta y alta prioridad para su conservación, por representar una importancia biológica en la escala continental y estar intactos. En cuanto a los corredores Sur y Ecotonos Sur-amazónicos, poseen relevancia biológica y se identificaron como vulnerables. No tienen grandes prioridades, pero son significativos para la conservación de estas áreas. Respecto a la Mata Atlántica, ambos corredores se identificaron como muy alta prioridad para su conservación. Poseen importantes recursos biológicos a pesar de estar muy amenazados.

En Brasil existen también las más grandes reservas de agua dulce del planeta, con un $12 \%$ del total mundial, pero con una distribución no uniforme. Amazonia tiene la mayor cuenca hidrográfica del mundo y, como es poco poblada, se ha mantenido la vegetación en sus márgenes, lo que facilita su conectividad ecológica. En los centros urbanos, sin embargo, las conexiones verdes en los ríos son prácticamente inexistentes por la densificación urbana, factores de contaminación y deforestación, aliados a una falta de planificación y gestión sostenible.

Como resultado de la pérdida natural, Pellegrino (2003) resalta que estos ríos han sufrido el deterioro de la calidad de vida urbana como consecuencia de la ocupación en las zonas de inundación, teniendo alarmantes niveles de contaminación del aire en los meses de sequía, efectos catastróficos de las inundaciones en los meses de mayores precipitaciones. Según el mismo autor, existe una realidad urbana que se vuelve fea, agresiva e insegura, lo que refleja una sociedad impotente para hacer frente a los problemas sociales y ambientales.

A pesar de que hay una potencialidad ambiental en el país, los parques y reservas existentes no son suficientes para la conservación de los ecosistemas. El conocimiento científico acumulado a través de los años en el campo de la biología de la conservación ha indicado que son necesarias áreas protegidas bastante extensas para la manutención de los procesos ecosistémicos a largo plazo (Ayres et al, 2005). Las pérdidas y la fragmentación de los espacios naturales generadas por los usos humanos han ocasionado, entre otros factores, el aislamiento de las poblaciones de múltiples especies, causando su riesgo de extinción. Además de esto, hay poco incentivo para la implementación y gestión de las conexiones verdes, solamente en algunos pocos casos. Este hecho conlleva a una necesidad de búsqueda de alternativas sostenibles de conectividades ecológicas en diversas escalas territoriales. 


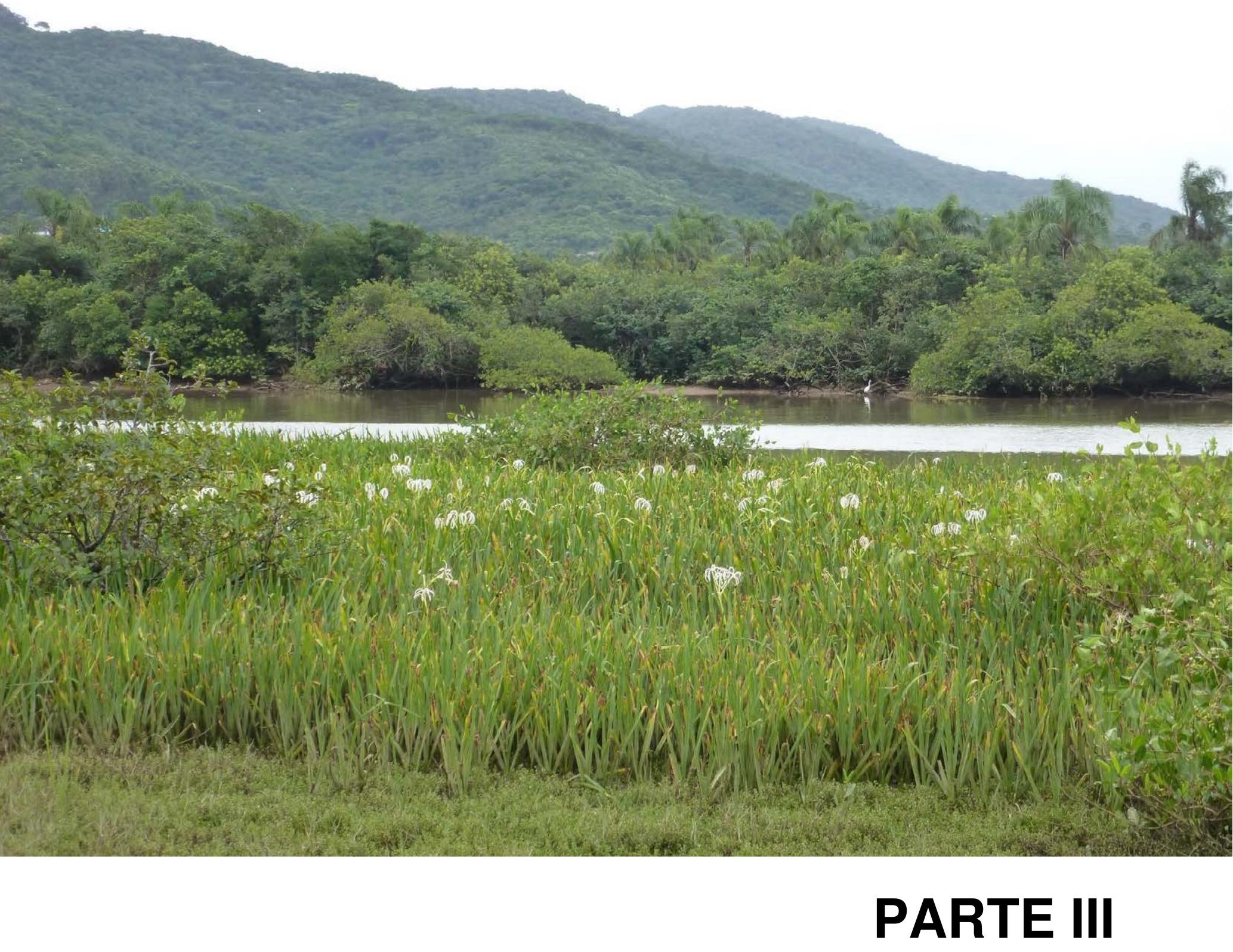

CASOS DE ESTUDIO 


\section{CARACTERIZACIÓN DE LOS PAISAJES DE MANGLARES DE LA REGIÓN METROPOLITANA DE FLORIANÓPOLIS}

El término paisaje se conceptualiza en diversos campos disciplinares. En la geografía, la biología, el urbanismo, la ordenación del territorio, entre otros, con diferentes delimitaciones según el ámbito temático desde el que se aborde. De una forma más amplia, se puede definir como una organización de los elementos espaciales de un territorio. Sin embargo, un paisaje no es estático y presenta dinámicas en el tiempo a causa de los factores antropogénicos. Por lo tanto, se considera como el resultado de la acción humana sobre un área geográfica (Sauer, 1925). Siguiendo la misma lógica, Burel y Baudry (2002, p. 18) definieron el paisaje como el resultado de una confrontación continua entre una sociedad y su entorno. Se caracteriza esencialmente por su heterogeneidad y su dinámica, en parte gobernada por las actividades humanas (Burel y Baudry, 2002, p. 43).

Según establece el Convenio Europeo del Paisaje ${ }^{17}$, se entiende paisaje como "cualquier parte del territorio tal como la percibe la población, cuyo carácter sea el resultado de la acción y la interacción de factores naturales y/o humanos". En este sentido, la percepción aporta como un observador del territorio por la cual transmite una comprensión más completa sobre el paisaje, esquematizado en la Figura 6.1.

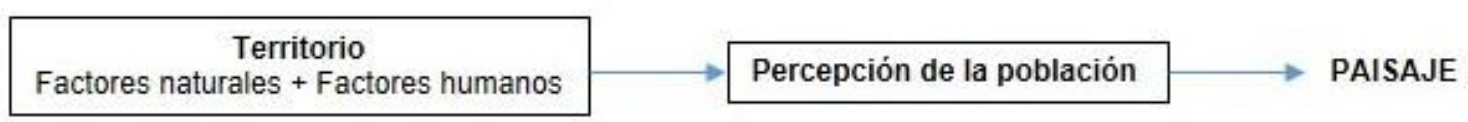

Figura 6.1: Concepto de paisaje. Fuente: Elaboración propia.

La existencia de la percepción conduce la idea del paisaje como cultural. Existen variados términos sobre este abordaje, sin embargo muchos de ellos con definiciones complejas. De una forma sencilla, se puede definir como un ámbito geográfico asociado a un evento, que abarcan valores estéticos y culturales, donde se vinculan historias y mensajes a espacios y formas (Sabaté, 2004). Se trata de un imagen que se invisibiliza tras el paisaje mítico para aferrarse con los elementos existentes de la naturaleza, fruto de la construcción material y

17 Convenio Europeo del Paisaje (2000). Consejo de Europa (Florencia). 
simbólica del territorio percibido (Pastor y Fuentes, 2009).

De acuerdo con el Plan Nacional de Paisaje Cultural ${ }^{18}$, el paisaje cultural es el "resultado de la interacción en el tiempo de las personas y el medio natural, cuya expresión es un territorio percibido y valorado por sus cualidades culturales, producto de un proceso y soporte de la identidad de una comunidad". En este sentido, el valor del paisaje es de gran importancia, una vez que la población es responsable de las directrices para su gestión, protección y ordenación, contribuyendo directamente para su mantenimiento.

Vinculado a estos conceptos, este capítulo trata de caracterizar los paisajes de manglares de la Región Metropolitana de Florianópolis, siguiendo las definiciones claves del significado del paisaje. Es importante resaltar que cada manglar, de forma aislada, es parte de un sistema mayor, lo que se relaciona con el paisaje de la Región Metropolitana en su totalidad. Por lo tanto, el análisis está directamente relacionado con los aspectos ecosistémicos y la ocupación del suelo a nivel regional metropolitano, comprobando que existe una relación de dependencia entre las diferentes escalas.

La caracterización de los paisajes de manglares de estudio está dividida en cinco subcapítulos, detallados a continuación:

6.1 UBICACIÓN DE LOS MANGLARES: situación de los manglares dentro del límite de la Región Metropolitana de Florianópolis.

6.2 FACTORES NATURALES: estudio de los componentes ecosistémicos bióticos y abióticos que conforman la Región Metropolitana, los que contribuyen para la comprensión ambiental de la formación de los manglares.

6.3 FACTORES HUMANOS: estudio del desarrollo de la ocupación del suelo en la Región Metropolitana de Florianópolis a lo largo de la historia y sus consecuentes impactos ambientales, que afectan directamente e indirectamente a los manglares.

6.4 CARACTERIZACIÓN ESPACIAL DE LOS PAISAJES DE MANGLARES: análisis de los nueve paisajes de manglares existentes, según la interrelación de los factores naturales y humanos.

6.5 PERCEPCIÓN DE LA POBLACIÓN: análisis del valor cultural de los paisajes de manglares de la Región Metropolitana de Florianópolis, a través de la percepción de la 18 MCU-IPCE, Ministerio de Cultura-Instituto del Patrimonio Cultural de España (2012). Plan Nacional de Paisaje
Cultural. 
PARTE III. Capítulo 6. CARACTERIZACIÓN DE LOS PAISAJES DE MANGLARES DE LA REGIÓN METROPOLITANA DE FLORIANÓPOLIS

población. 


\subsection{UBICACIÓN DE LOS MANGLARES}

En el territorio de la Región Metropolitana de Florianópolis, perteneciente al Estado de Santa Catarina, se encuentran en su totalidad nueve formaciones de manglares. Están en el límite Sur respecto a las áreas con presencia de manglares del continente americano, situados en el séptimo segmento de la costa brasileña, relativo al grado de desarrollo y las características estructurales de los manglares ${ }^{19}$. Pasado ese límite, desaparecen estos peculiares paisajes debido a las bajas temperaturas en la zona subtropical y también por la presencia de olas fuertes en esta localidad. Estos manglares se sitúan entre las Latitudes $27^{\circ} 29^{\prime} 21,66^{\prime \prime}$ y $27^{\circ} 50^{\prime}$ $05,46^{\prime \prime}$ Sur y entre las Longitudes $48^{\circ} 40^{\prime} 07,05^{\prime \prime}$ y $48^{\circ} 27^{\prime} 58,31^{\prime \prime}$ Oeste, ubicados en la costa insular y continental de la Región Metropolitana, bañados por las Bahías Norte y Sur (Figura 6.2).

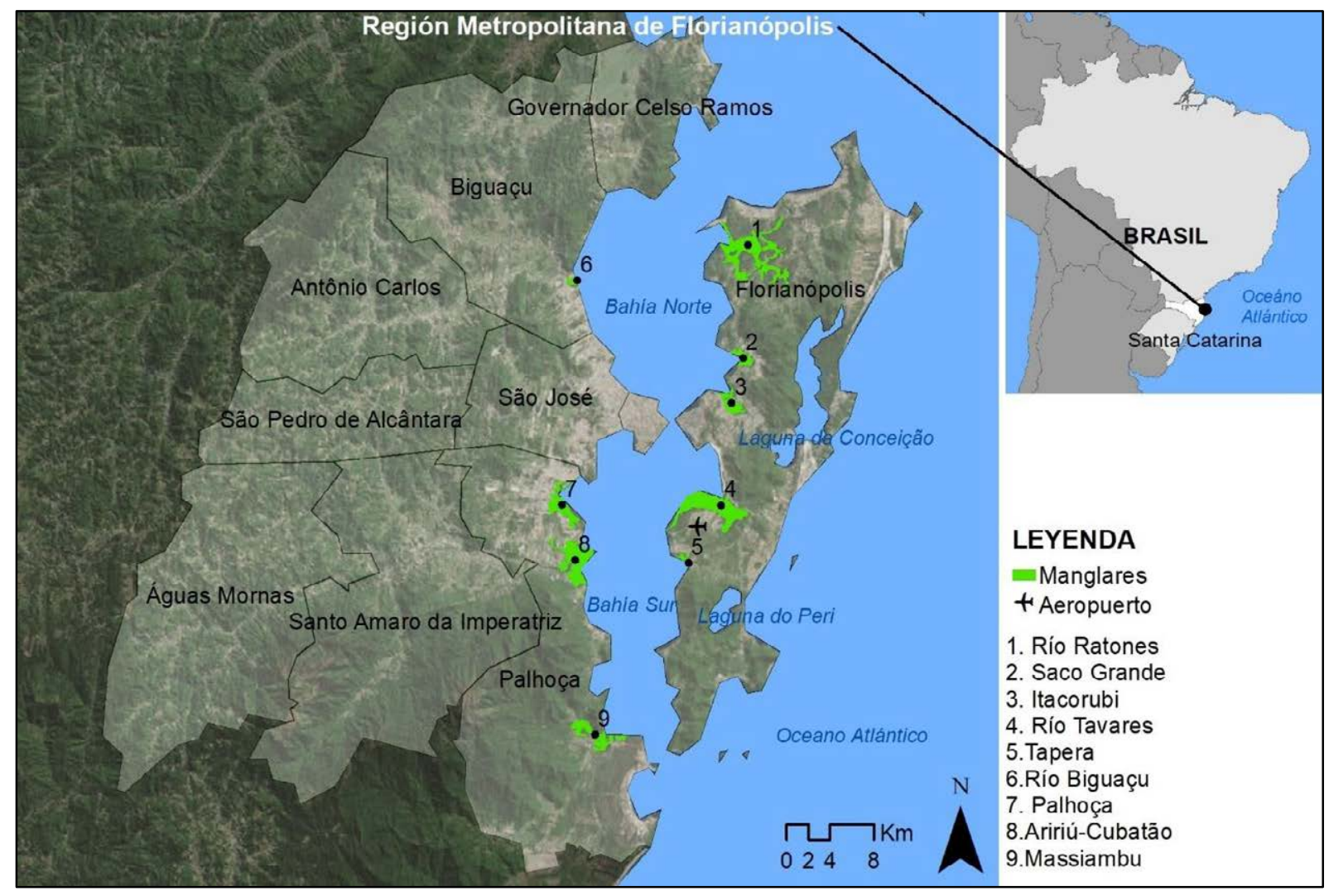

Figura 6.2: Ubicación de los manglares en la Región Metropolitana de Florianópolis. Fuente: Elaboración propia.

\footnotetext{
19 Demostrado en la sección 3.2.3.
} 
A causa de la ocurrencia de olas fuertes en la costa Sur de Brasil, los manglares se encuentran solamente en las zonas más protegidas. Según Citrón y Schaefer-Novelli (1981, p. 12), los manglares más desarrollados en estas áreas están asociados a las bahías y las lagunas costeras. En el caso de la Región Metropolitana, el desarrollo de los manglares se da por la presencia de las Bahías Norte y Sur. Las Bahías se comunican con el Océano Atlántico por dos embocaduras: la primera al Norte, con unos $10 \mathrm{~km}$ de ancho, y la segunda al Sur, con acerca de $1 \mathrm{~km}$. Estas dos embocaduras forman una especie de canal que las diferencian de la mayoría de las bahías que sólo tienen una abertura hacia el mar. Alrededor de la Latitud $27^{\circ} 36^{\prime}$ Sur, posee un estrechamiento que dividen las Bahías Norte y Sur. Al total, las dos Bahías cuentan con cerca de $19 \mathrm{~km}$ de largo y una superficie de 146,17 km².

En el lado insular se encuentran los manglares del Río Ratones, de Saco Grande, de Itacorubi, del Río Tavares y de Tapera, ubicados en el Municipio de Florianópolis. En el continente se sitúa el manglar del Río Biguaçu, en el Municipio de Biguaçu, y los manglares de Palhoça, de Aririú-Cubatão y de Massiambu, en el Municipio de Palhoça. Además de estos manglares, según Cruz (1998, p. 23), existen otras formaciones en el territorio, en estados degradados, totalmente destruidas o en reconstitución natural. Estas vegetaciones están situadas en pequeñas áreas dispersas tanto en la isla, como en el continente. Sin embargo no son relevantes para este estudio.

\subsection{FACTORES NATURALES}

Los factores naturales de los paisajes de manglares están directamente relacionados con la estructura ambiental física y biológica del territorio. Por lo tanto, este subcapítulo se dedica al análisis de los componentes ecosistémicos bióticos y abióticos de la Región Metropolitana de Florianópolis, con el fin de caracterizar y especificar la formación de los manglares.

\subsubsection{Componentes abióticos}

Para entender los componentes abióticos, o sea, las condicionantes físicas que componen el ambiente de la Región Metropolitana de Florianópolis, están divididos en cinco partes, mostrados en las siguientes secciones, como: la formación geológica; la geomorfología y el relieve; la edafología; las mareas y la circulación marítima; el clima, los fenómenos y los cambios climáticos; y la hidrografía. 


\subsubsection{Formación geológica}

La formación geológica de la Región Metropolitana de Florianópolis se caracteriza por la fusión de tres grandes unidades geológicas. Se compone del Basamento Cristalino, de la era Arqueozoica hasta finales de la era Proterozoica; de la Cobertura Vulcano Sedimentaria EoPaleozoica, de la era Paleozoica; y de la Cobertura Sedimentaria Cuaternaria, del periodo Cuaternario de la era Cenozoica. Estas formaciones están especificadas por Santa Catarina (1991, p. 16) y demostradas en la Figura 6.3. De acuerdo con la Tabla 6.1 siguiente, se verifican los años históricos en relación a la era y el periodo de las unidades geológicas en la Región Metropolitana.

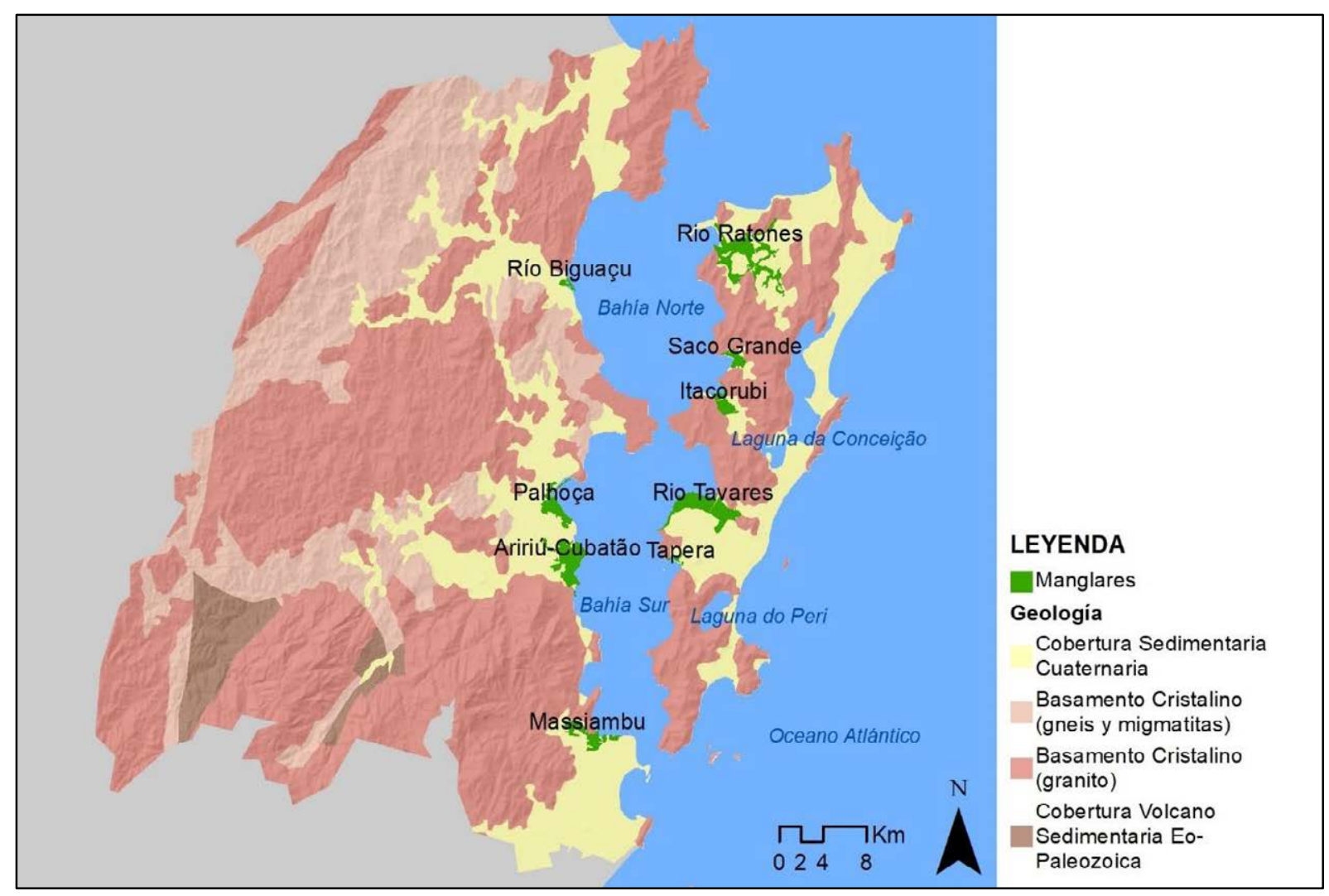

Figura 6.3: Formación geológica. Fuente: Elaboración propia con los datos de la Companhia de Pesquisa de Recursos Minerais, CPRM (1986) ${ }^{20}$.

${ }^{20}$ Mapa digital disponible en http://ciram.epagri.sc.gov.br (fecha de consulta: abril de 2016). 


\begin{tabular}{|c|c|c|c|}
\hline Era & Periodo & $\begin{array}{c}\text { Unidad Geológica } \\
\text { Región Metropolitana de Florianópolis }\end{array}$ & Millones de años \\
\hline \multirow{2}{*}{ Cenozoica } & Cuaternario & Cobertura Sedimentaria & 2,5 \\
\hline & Terciario & & 65 \\
\hline \multirow{3}{*}{ Mesozoica } & Cretácico & & 136 \\
\hline & Jurásico & & 190 \\
\hline & Triásico & & 225 \\
\hline \multirow{6}{*}{ Paleozoica } & Permiano & \multirow{6}{*}{ Cobertura Vulcano Sedimentaria } & 280 \\
\hline & Carbonífero & & 345 \\
\hline & Devoniano & & 393 \\
\hline & Siluriano & & 430 \\
\hline & Ordoviciano & & 500 \\
\hline & Cambriano & & 570 \\
\hline \multicolumn{2}{|c|}{ Proterozoica } & \multirow{2}{*}{ Basamento Cristalino } & 2500 \\
\hline \multicolumn{2}{|c|}{ Arqueozoica } & & 4600 \\
\hline
\end{tabular}

Tabla 6.1: Unidades geológicas. Fuente: Elaboración propia.

El Basamento Cristalino incluye las rocas más antiguas, constituidas de granito en las zonas cercanas de la costa, debido a su mayor resistencia a las intemperies, y gneis y migmatitas en las zonas hacia el interior continental.

La Cobertura Vulcano Sedimentaria Eo-Paleozoica se compone, predominantemente, de rocas sedimentarias representadas por areniscas (arcosa), conglomerados, limolitas, pizarras y filitas, con frecuente asociación de rocas volcánicas extrusivas.

Finalmente, de importancia para este estudio, la Cobertura Sedimentaria Cuaternaria es la unidad geológica donde propició la aparición de los manglares en la Región Metropolitana, y se considerada la formación más reciente. Consiste en sedimentos no consolidados o poco consolidados de arenas, limos, arcillas o conglomerados, traídos por la acción de los ríos, vientos, lluvias y mar.

La Cobertura Sedimentaria es también el resultado de las variaciones del nivel del mar que ocurrió durante el período Cuaternario. Consta en el pasado geológico reciente (de unos 120 mil años) que el nivel del mar era de unos $8 \mathrm{~m}$ a $10 \mathrm{~m}$ más elevado que actualmente. Lo que significa que muchas áreas de la parte insular del Municipio de Florianópolis de bajas altitudes fueron cubiertas por el mar y que los puntos más altos estaban rodeados de agua, formando variadas islas (Luiz, 2004, p. 26). Se quedaron por encima de la superficie del mar dos grandes bloques y variadas pequeñas islas a su alrededor. La mayoría de ellas poseían una media de aproximadamente $34 \mathrm{~km}$ de largo y $6 \mathrm{~km}$ de ancho (Santa Catarina, 1986, p. 13), según 
muestra la Figura 6.4.

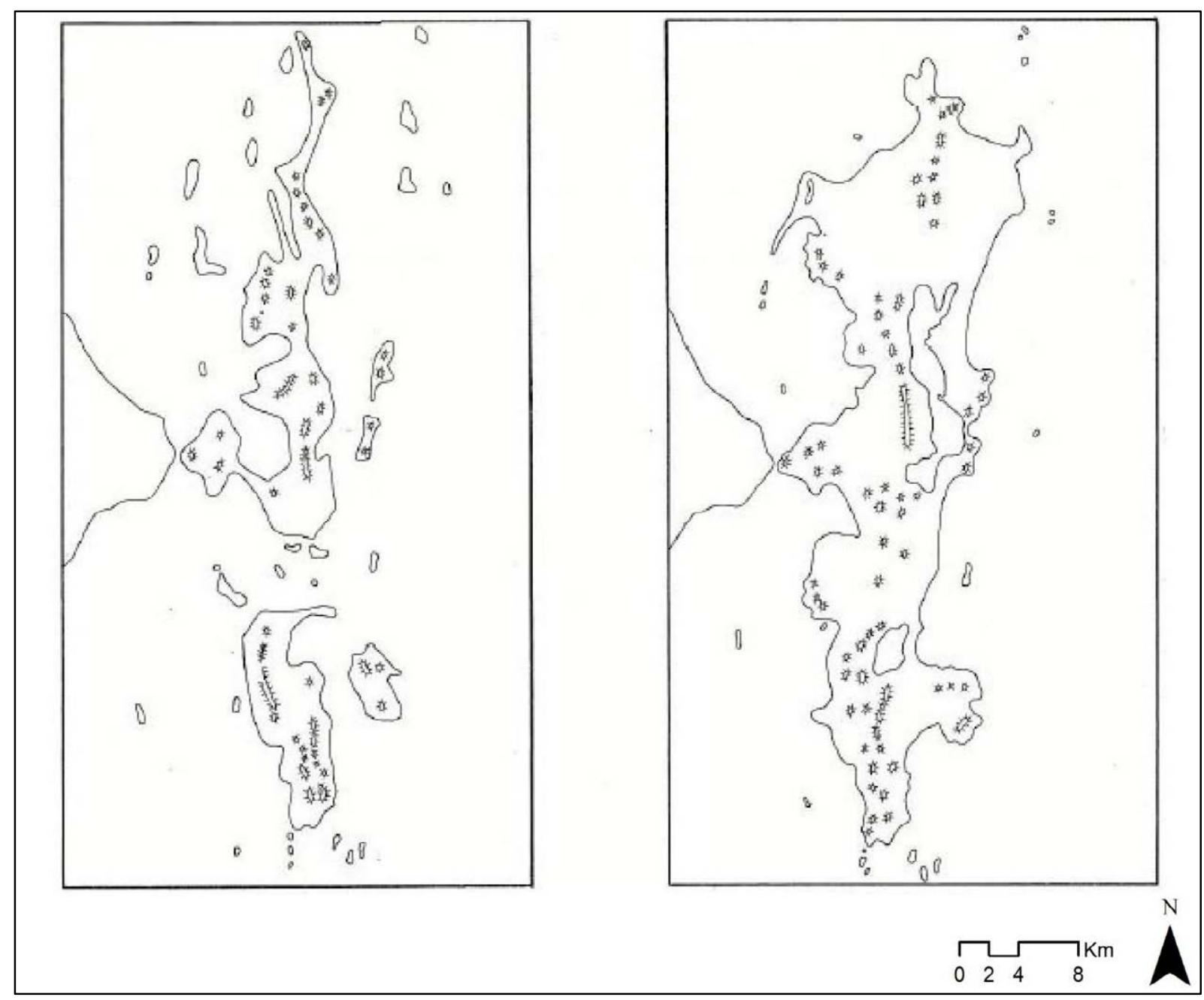

Figura 6.4: Dibujo de la comparación entre el pasado geológico (a la lzquierda) y el actual (a la derecha) en la isla del Municipio de Florianópolis. Fuente: Vieira da Rosa (1905).

A pesar de la oscilación del nivel del mar durante el período Cuaternario, los manglares han sido capaces de establecerse, y han presentado gran capacidad de adaptación. Sin embargo, según Santos (2014, p. 244), esto depende del tipo de daño y de su intensidad. La autora señala que uno de los testigos de su adaptación son los registros arqueológicos, tal como los de los sambaquis ${ }^{21}$, que demuestran que los manglares consiguen establecerse durante el movimiento de elevación y descenso del nivel del mar. Ocupan las zonas superiores e inferiores en los estuarios y mantienen el ecosistema vivo.

21 Sambaquis es una palabra de origen indígena. Están compuestos por esqueletos de humanos y animales prehistóricos y herramientas hechas de piedra o de hueso. A través de los estudios de los sambaquis, se puede saber sobre la vida de las primeras ocupaciones humanas en Brasil, tal como su alimentación, sus conocimientos técnicos, además de investigaciones sobre la fauna y la flora del momento histórico. 


\subsubsection{Geomorfología y relieve}

La geomorfología y relieve es el resultado de la formación geológica y de los agentes externos a través del tiempo, tal como el mar, el viento, los ríos y las lluvias. En la Región Metropolitana de Florianópolis se distinguen en unidades diferenciadas de relieve, entre ellas: las Sierras del Este Catarinense (relacionada con el Basamento Cristalino y la Cobertura Volcano Sedimentaria Eo-Paleozoica), las Llanuras Fluviales y Costeras (relacionadas con la Cobertura Sedimentaria Cuaternaria) (Figura 6.5)

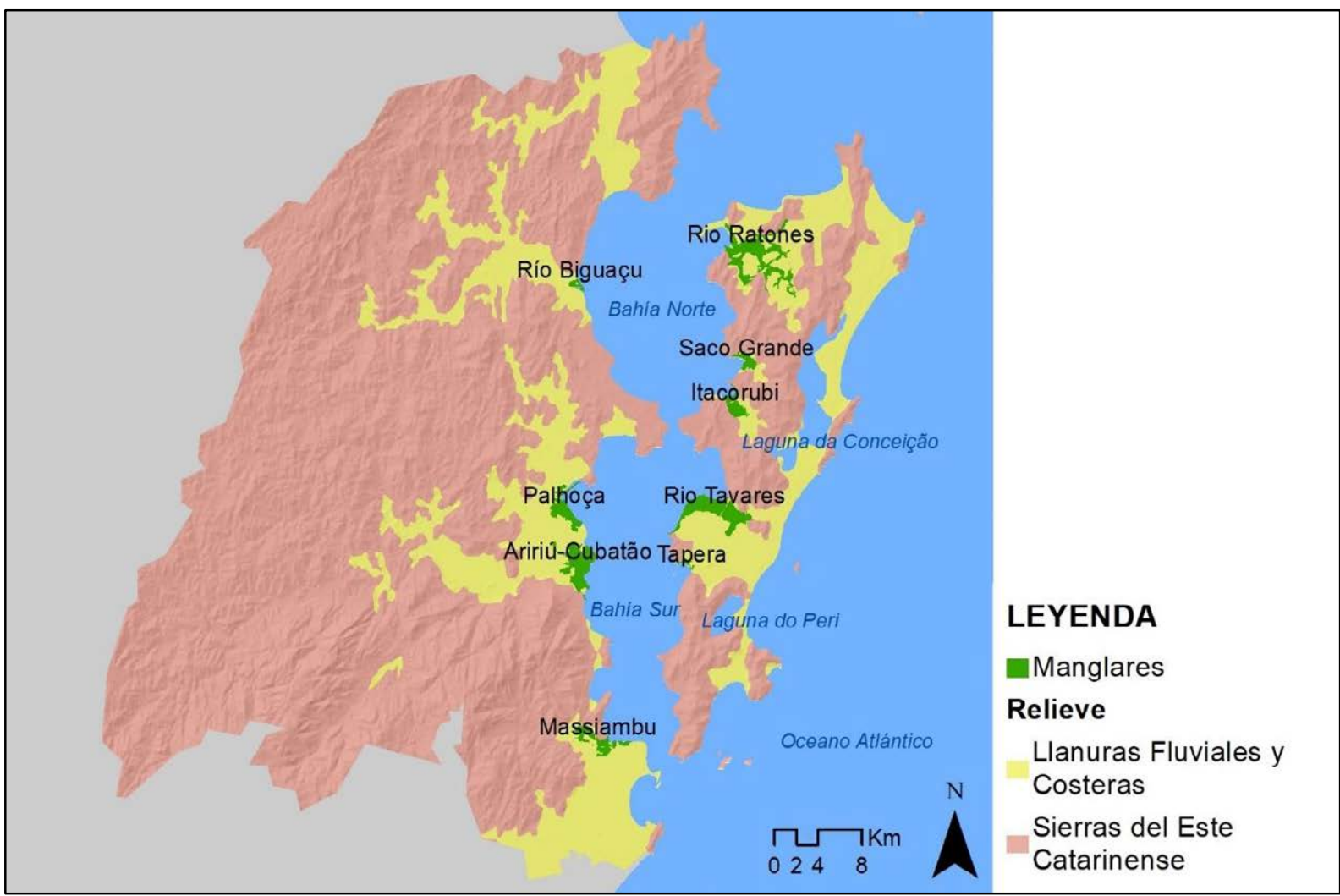

Figura 6.5: Unidades de relieve. Fuente: Elaboración propia con los datos de la CPRM (1986)22.

La primera unidad, las Sierras del Este Catarinense, se relaciona con las áreas más altas del territorio. Están identificadas como modelamiento de disecación, donde los procesos de erosión predominan sobre los procesos de sedimentación (Hermann y Rosa, 1991) ${ }^{23}$, tal como las colinas (altura entre 50 y 60 metros, con pendientes suaves y la cima convexa), morros (altura entre 100 y 200 metros, con pendientes pronunciadas y la cima angular) y montañas (altura a partir de 200 metros, con pendientes pronunciadas y la cima angular) (Luiz, 2004, p.

22 Mapa digital disponible en http://ciram.epagri.sc.gov.br (fecha de consulta: abril de 2016).

${ }^{23}$ Apud Luiz (2004, p. 25). 
25).

Las áreas correspondientes a las Sierras del Este Catarinense más cercana de la costa están a unos 100 metros de altura, mientras que las áreas hacia el interior del continente de la Región Metropolitana están alrededor de los 900 metros, como se observa en la Figura 6.6. Destaca como pico muy alto en el territorio el Morro do Cambirela (1.043 m) (Santa Catarina, 1986, p. 33), en la parte continental Sur con proximidad al mar. En la parte insular, destaca el Morro da Lagoa (493 m), en la parte central de la isla, y el Morro do Ribeirão (532 m), al sur (Almeida, 2004, p. 22). En general, las pendientes están a partir del $5 \%$, pero las más pronunciadas son las que están por encima del $30 \%$. De acuerdo con Luiz (2004, p. 25), las pendientes pronunciadas son consideradas el principal obstáculo para la ocupación en las localidades cuyos suelos superficiales no tienen vegetación y son susceptibles a los fenómenos erosivos.

La segunda unidad, Llanuras Fluviales y Costeras, son consideradas las altitudes más bajas, que se ubican junto a las cuencas hidrográficas y en las zonas de costa, respectivamente. Las áreas más altas de estas unidades corresponden a una altura entre 10 y 30 metros, y las áreas más bajas, llamadas de áreas inundables, son consideradas las cotas inferiores a cinco metros, donde se encuentran los manglares. En cuanto a las pendientes, son identificadas como zonas prácticamente llanas (oscilando entre el $0 \%$ y $5 \%$ ) y zonas de valles (depresión alargada surcada por las aguas de los ríos) (Luiz, 2004, p. 25). De acuerdo con la Figura 6.5, se perciben estas unidades de una forma discontinua tanto en la parte insular como continental. 


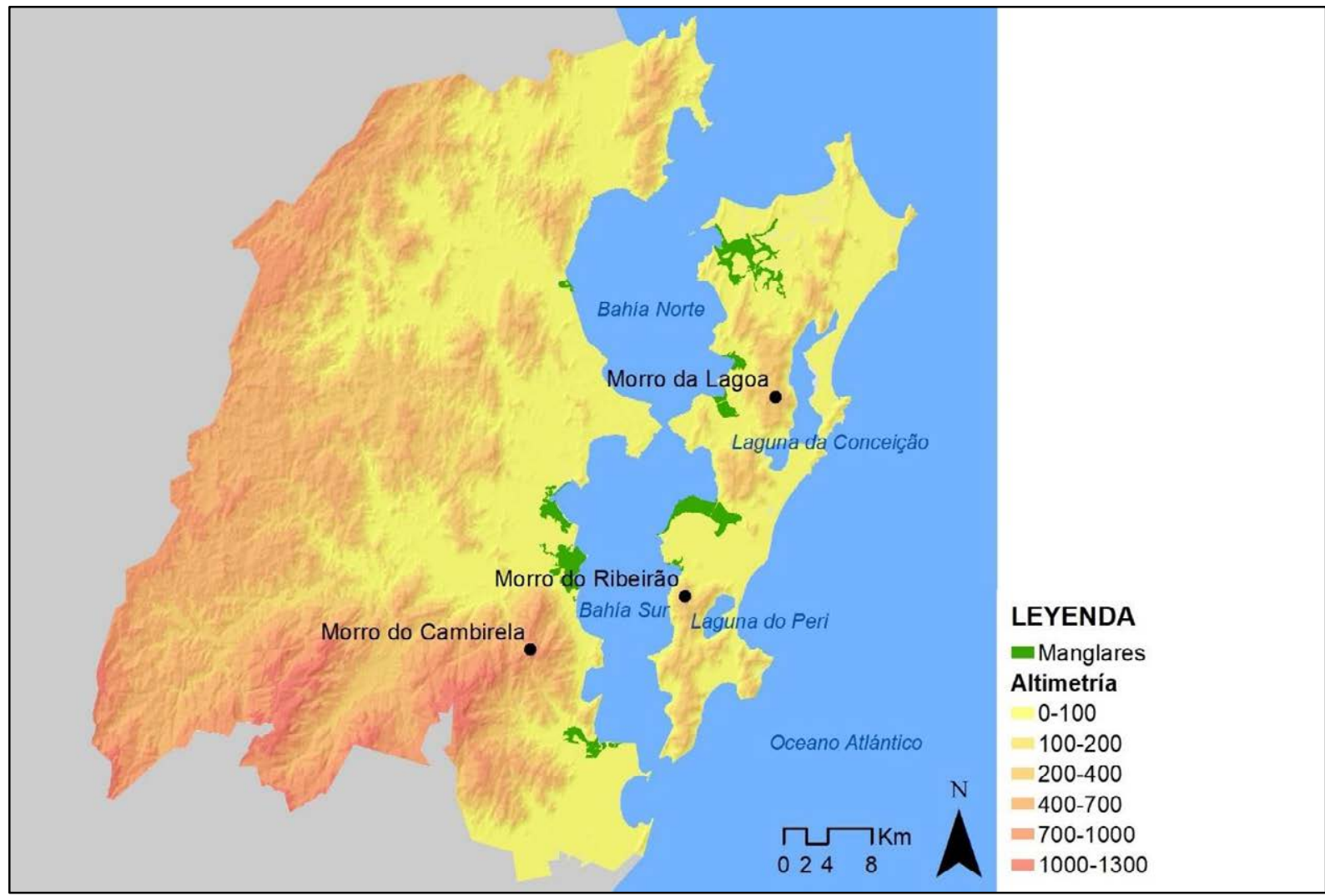

Figura 6.6: Altimetría. Fuente: Elaboración propia con los datos de la Empresa de Pesquisa Agropecuária e Extensão Rural de Santa Catarina, Epagri (2007) ${ }^{24}$.

La Llanura Costera, donde se ubican los manglares, está formada por los sedimentos depositados a lo largo del tiempo por la acción de los agentes externos. Los diferentes tipos sedimentos dan origen a las variaciones de relieve, que se pueden caracterizar según sus compartimientos y se distinguen en: Eólico, Colúvio-Aluvionar y Praial, denominados por Herrmann y Rosa (1991) ${ }^{25}$ y representados en la Figura 6.7.

${ }^{24}$ Mapa digital disponible en http://ciram.epagri.sc.gov.br (fecha de consulta: abril de 2016).

${ }^{25}$ Apud Luiz (2004, p. 26). 


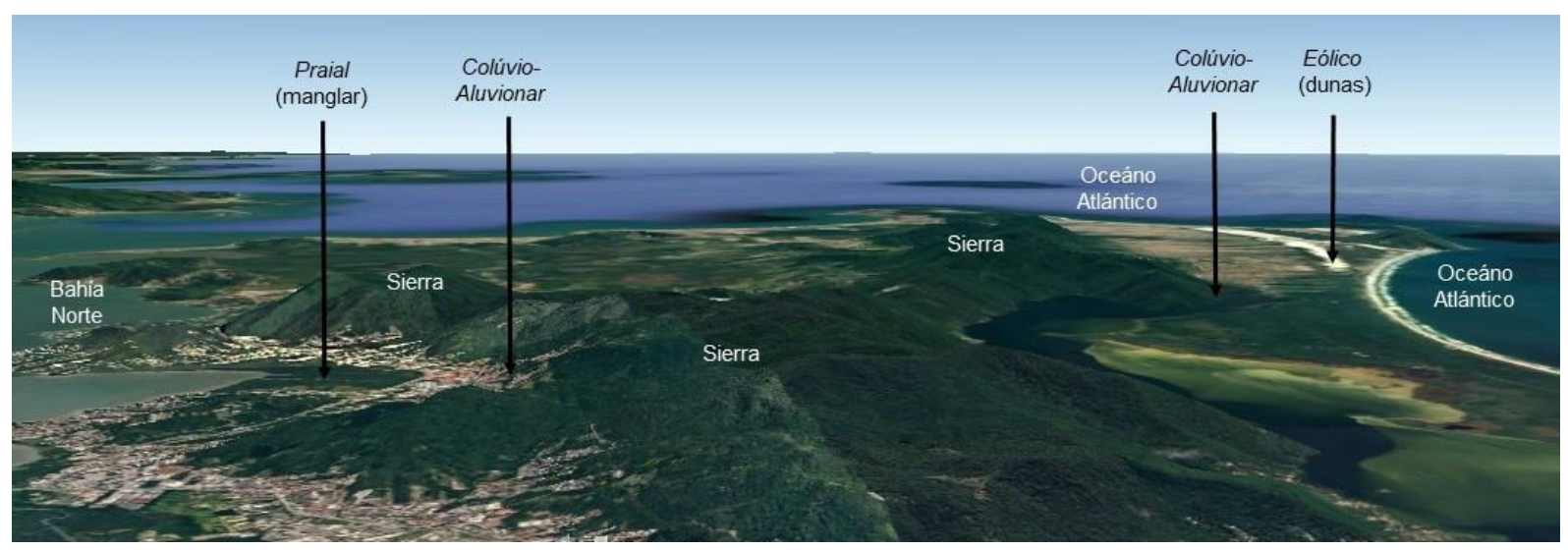

Figura 6.7: Llanura Costera (parte Norte de la Isla del Municipio de Florianópolis). Compartimentos Eólico, Colúvio-Aluvionar y Praial. Fuente: Elaboración propia a partir de Google Earth (2016).

El Compartimento Eólico consiste en formas de relieve creadas a partir de la acción del viento sobre el ambiente costero. En el Municipio de Florianópolis, al Este de la isla, hacen parte de este compartimento las dunas móviles y las dunas estabilizadas (con vegetación).

El Compartimento Colúvio-Aluvionar representa la transición entre las unidades de Llanura Costera y de Sierras del Este Catarinense. Se presenta en forma de rampas, constituidas por depósitos de sedimentos de diferentes tamaños que se extiende por la Llanura Costera.

El Compartimento Praial es formado de relieves creados a partir de sedimentos transportados y depositados principalmente por las olas, las corrientes marinas y los vientos. Se encuentran en este compartimento: las playas (volcadas tanto hacia el lado del Océano Atlántico, cuanto hacia las Bahías Norte y Sur), las terrazas marinas (con formas de escalera formadas por los sedimentos arenosos depositados por el mar), las llanuras de restinga (formadas por el acúmulo de arena venido de las corrientes marinas costeras), las llanuras lacustres (formadas por los escombros que las lagunas sufren con el tiempo debido a la llegada de sedimentos aportados por los ríos, la lluvia y el viento, y configuran a una zona rebajada y pantanosa con suelo oscuro) y las llanuras de marea (responsable por la formación de los manglares).

Es en las llanuras de marea que ocurre el desarrollo de los manglares. Estas llanuras se sitúan en las zonas de mar calmo de las Bahías Norte y Sur, en las hendiduras costeras y en las desembocaduras de los ríos, con el fondo marino poco profundo.

\subsubsection{Edafología}

La edafología estudia la caracterización de los suelos y su relación con los seres bióticos del entorno. La Región Metropolitana de Florianópolis presenta una gran diversificación de tipos 
de suelos. Según los datos de Santa Catarina (2014, p. 145), los tipos suelos predominantes en las Sierras del Este Catarinense son los Acrisoles (rocas ácidas, con acumulación de arcilla) y los Cambisoles (suelos con cambios de estructura y colores en su perfil). En cuanto a las áreas que componen las Llanuras Fluviales y Costeras, los tipos de suelos predominantes son los Entisoles (suelos poco desarrollados y con poca anchura) y los Gleysoles (suelos con exceso de humedad).

Los suelos que forman los manglares son designados de Gleysoles Tiónicos, que presentan textura arcillosa y cuentan con la presencia de azufre y sales (Sommer y Rosatelli, 1991) ${ }^{26}$. Según la Empresa Brasileira de Pesquisa Agropecuária (Embrapa) ${ }^{27}$, no se recomienda drenar los suelos que presentan el carácter Tiónico, pues el agua se vuelve muy ácida $(\mathrm{pH}$ cercano a 3,5), no siendo recomendable para el uso agrícola, solamente para la preservación.

El color oscuro que se presenta en los manglares y, ocasionalmente, su mal olor, es debido al material orgánico que no se descompone por completo, por poseer un suelo encharcado por la inundación de las mareas (Sommer y Rosatelli, 1991) ${ }^{28}$. Este tipo de suelo es adecuado para el desarrollo de flora y fauna típica de los manglares, presentando características muy diferenciadas en comparación con los otros tipos de suelo.

\subsubsection{Mareas y corrientes marítimas}

A partir de los datos obtenidos de las Tablas de Mareas $^{29}$, se constata que las mareas de la Región Metropolitana de Florianópolis están sujetas a un régimen semidiurno, al igual que toda la costa brasileña, y tardan aproximadamente 12 horas en completar el ciclo de inundación. La frecuencia de inundación del suelo en los manglares es de 512 veces al año (IBAMA, 2003, p. 24, cap. 4).

La amplitud media de la marea, según los datos de la Diretoria de Hidrografia e Navegação (DHN, n 1903), varía entre 0,93 m y 0,54 m. La inundación por las mareas se caracteriza como baja en comparación con el resto de la costa brasileña, aunque los períodos de inundación en las llanuras costeras son de gran importancia para la formación de manglares,

\footnotetext{
${ }^{26}$ Apud Luiz (2004, p. 44).

${ }^{27}$ Embrapa, Empresa Brasileira de Pesquisa Agropecuária. Disponible en http://www.agencia.cnptia.embrapa.br/ (fecha de consulta: junio de 2018).

${ }^{28}$ Apud Luiz (2004, p. 44).

29 Tablas de Mareas. Disponible en http://www.mar.mil.br/dhn/chm/box-previsao-mare/tabuas/ (fecha de consulta: junio de 2016).
} 
donde se acumulan los nutrientes y sedimentos formando un terreno fangoso.

La extensión de los manglares puede variar de acuerdo con la amplitud de inundación a causa de la topografía. Cuanto mayor sea el alcance de las mareas, mayor será la superficie de este ecosistema. Un claro ejemplo es el manglar del Río Ratones, con una amplia zona de llanura de inundación, considerada la mayor formación de manglar de la Región Metropolitana (Figura $6.8)$.

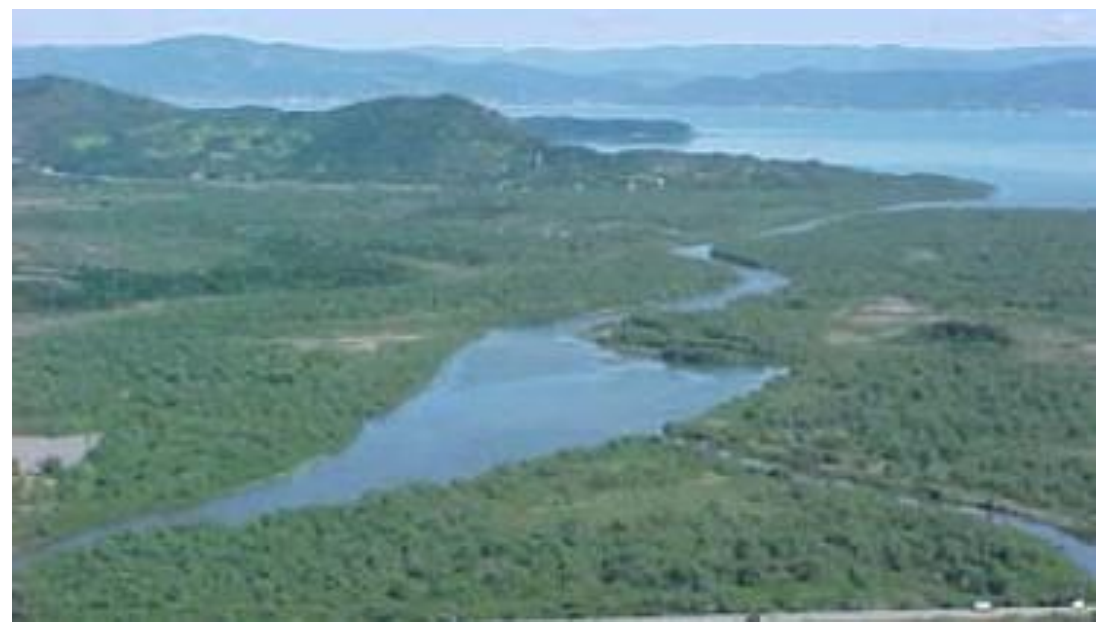

Figura 6.8: Manglar del Río Ratones. Fuente: IBAMA (2003, p. 5, cap. 6).

La corriente marina, inducida por la marea alta, entra por la Bahía Norte debido a la embocadura más ancha, y se encuentra con el flujo que viene del Sur. En el interior de la Bahía Sur existe un área donde la corriente es casi inexistente (Figura 6.9). La situación se invierte cuando la marea está bajando con el agua saliendo de las Bahías a partir de este punto de encuentro. Según Huber (2004, p. 75), el patrón de la corriente del agua en las Bahías es debido a la diferencia entre los anchos de las embocaduras. Cuando el nivel del agua sube, el flujo de agua que entra en la embocadura del Sur es mucho menor que el flujo entra por la del Norte. De esta forma, el punto de encuentro de las dos corrientes está en la Bahía Sur. 


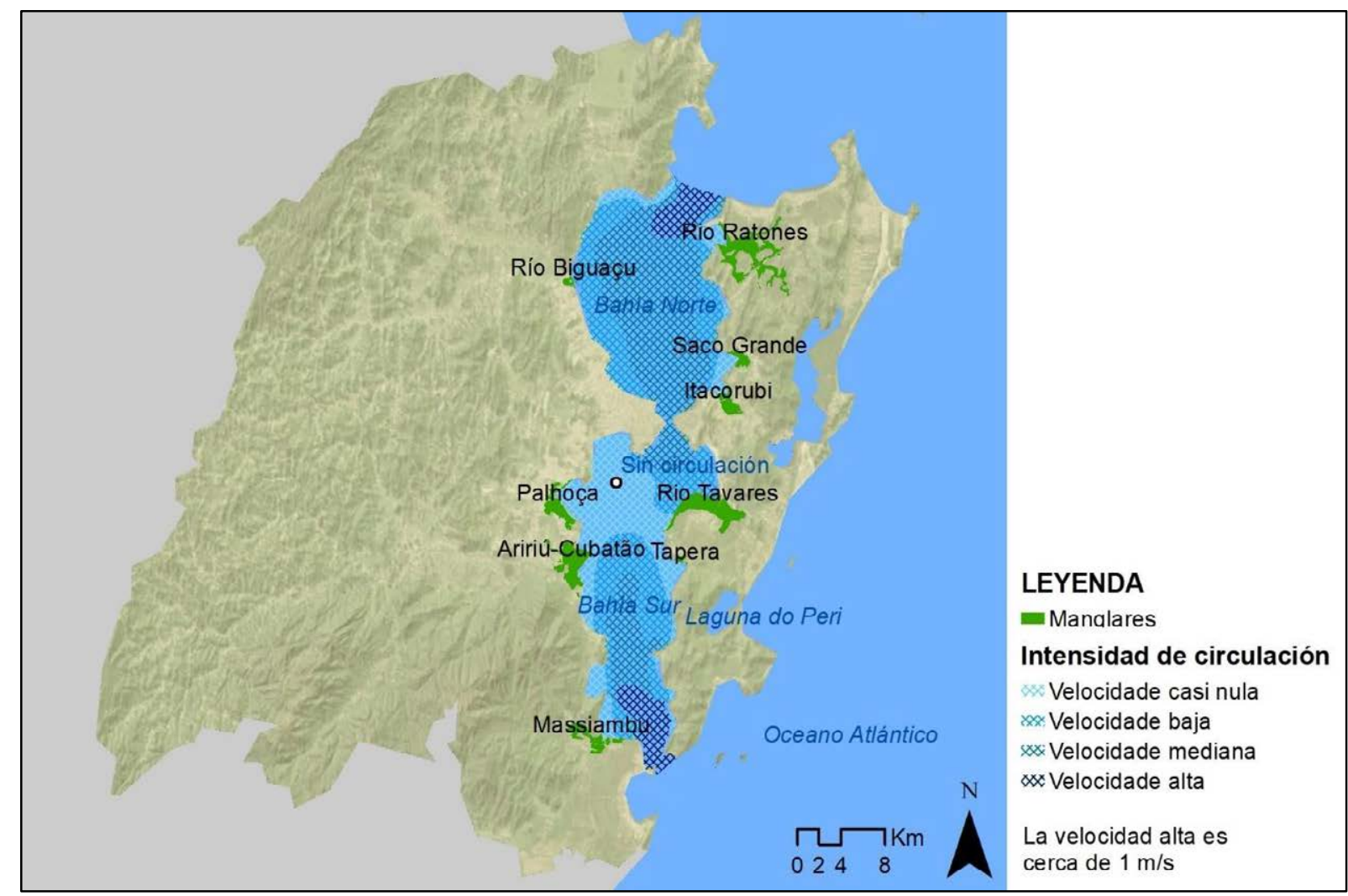

Figura 6.9: Intensidades de la corriente marítima en las Bahías Norte y Sur. Fuente: Elaboración propia con los datos de IBAMA (2003, p. 26 y 27 , cap. 4).

Como se puede observar en la figura anterior, en el área donde la corriente marina es casi inexistente predominan las formaciones de manglares. Conforme Huber (2004, p. 75), en la Bahía Sur, debido a la pequeña abertura, la velocidad de las corrientes es lenta, favoreciendo las formaciones de manglar tanto en la costa insular (manglares del Río Tavares y de Tapera), como en la costa continental (manglares de Massiambu, de Aririú-Cubatão y de Palhoça). En la Bahía Norte, las formaciones más relevantes de manglares están en la costa insular (manglares del Río Ratones, de Saco Grande y de Itacorubi) por estar protegidas geomorfológicamente de las corrientes, posibilitando la formación de sedimentos. Ya en la costa continental, el manglar del Río Biguaçu se presenta menos significativo en relación a las otras formaciones por su aproximación con las corrientes.

La corriente marítima en las Bahías también induce en su profundidad. El promedio de profundidad es de 3,5 m, llegando a un máximo de 28 m (IBAMA, 2003, p. 23, cap. 4). Las profundidades máximas coinciden con las áreas donde se sitúan los estrechamientos formados por la parte insular y continental en las Bahías Norte y Sur, zona que genera un gran flujo de agua. 


\subsubsection{Clima, fenómenos y cambios climáticos}

Para poder definir el clima de una localidad es necesario tener en cuenta los factores climáticos, tal como son la acción de la radiación solar, la altitud, la continentalidad, las masas de aire y las corrientes oceánicas. Los factores se relacionan entre sí y tienen una clasificación diferenciada para cada parte distinta del mundo. La clasificación climática se define por la temperatura, la precipitación, la humedad y la presión atmosférica.

Según la clasificación de Köppen-Geiger, la Región Metropolitana de Florianópolis tiene un clima subtropical, mesotérmico húmedo y verano cálido (Cfa) cerca de la costa de la Región Metropolitana; y un clima templado, mesotérmico húmedo y verano ameno $(\mathrm{Cfb})$ en la parte más a Oeste (Figura 6.10). Están caracterizados por periodos de verano e invierno bien definidos, con ocurrencia de precipitación en todos los meses del año e inexistencia de una estación seca definida (Peel et al., 2007).

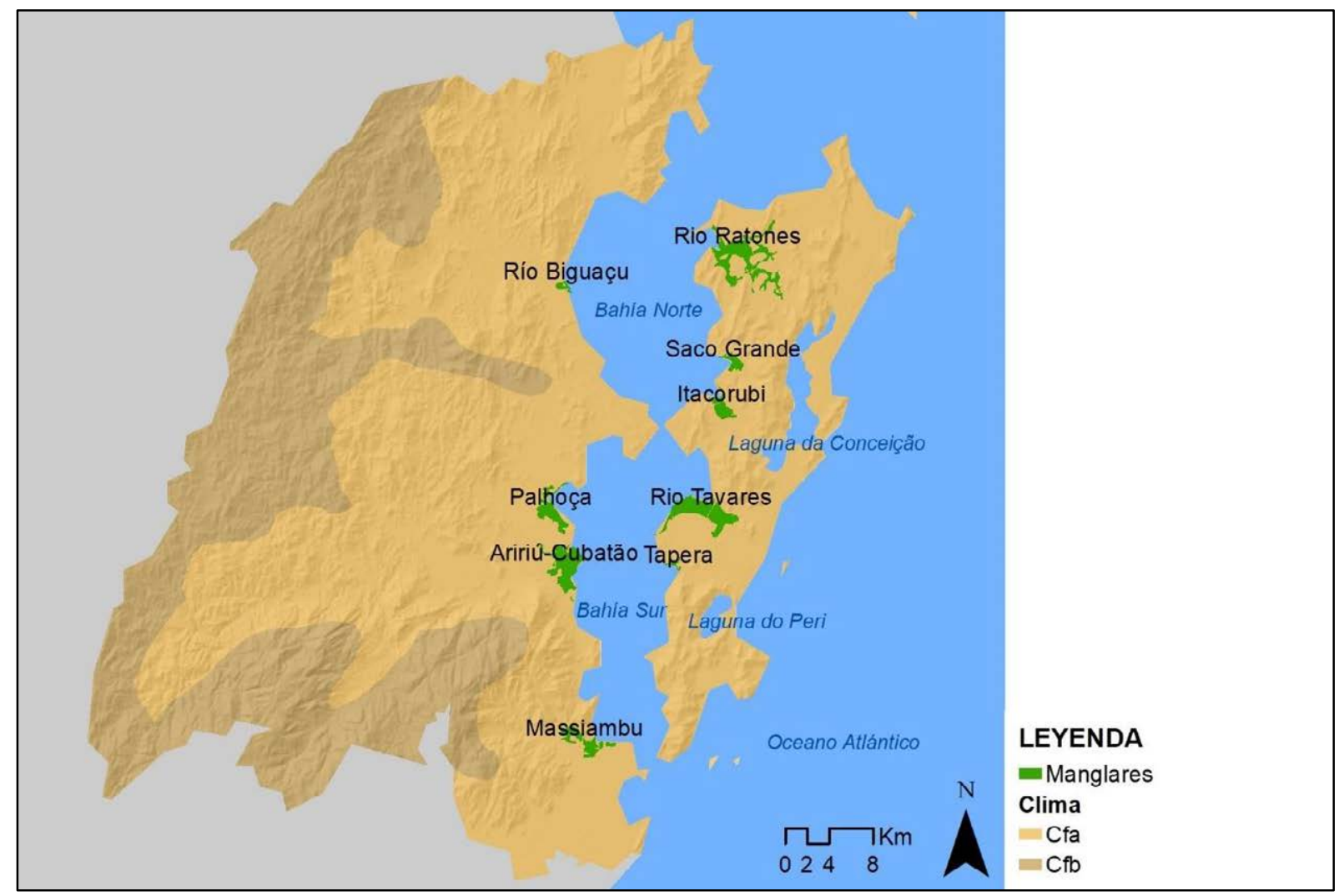

Figura 6.10: Clasificación de Köppen-Geiger. Fuente: Elaboración propia con los datos de Pandolfo et al. (2002).

El clima también está estrictamente relacionado con la vegetación. Mientras que el clima configura un tipo de vegetación, la vegetación también contribuye para el microclima, donde influye sobre la humedad, radiación solar y el control del viento (Higueras García, 2006, p. 
84). En el caso de los manglares, la clasificación Cfa de la Región Metropolitana está en concordancia con el desarrollo de esta vegetación, donde posee un clima cálido en las latitudes más bajas del Sur de Brasil. Sin embargo, se percibe una distinción relacionada con el Noreste del País, de especies de manglares menos numerosas, presentando una formación de bosque de transición, entre un clima cálido y mesotérmico (Nimer, 1989, p. 260 y 261).

Las condiciones climáticas dependen de la actuación de la Masa Tropical Atlántica, que es la masa de aire intertropical originada del Anticiclón Semifijo del Atlántico y de la Masa Polar del Atlántico, originada de la zona Subantártica (Santa Catarina, 1991, p. 24; PMISB, 2010, p. 16). La Masa Tropical Atlántica funciona durante todo el año, especialmente en primavera y verano, mientras que la Masa Polar Atlántica actúa con más frecuencia en otoño e invierno. El Frente Polar Atlántico es resultado del contacto entre la Masa Tropical Atlántica con la Masa Polar Atlántica, y es responsable por un buen equilibrio de distribución de lluvia durante el año (Santa Catarina, 1991, p. 24).

De forma resumida, durante todo el año en cualquier parte de la Región Sur de Brasil hay cambios de tiempo, en los que se dividen en cuatro grupos principales, según Nimer (1989, p. 251):

1. Tiempo estable, con temperatura mediana a alta, bajo el dominio del Anticiclón Subtropical del Atlántico Sur;

2. Tiemplo inestable, con lluvias de poca a mediana intensidad, que acompañan el paso del Frente Frío en fase de oclusión y alta humedad relativa;

3. Retorno del tiempo estable bajo el dominio del Anticiclón Polar, trayendo un clima soleado, baja temperatura, baja humedad relativa y la calmaría;

4. Con la desaparición del Anticiclón Polar, recomienza de nuevo el ciclo.

En cuanto a los promedios de las temperaturas anuales en la Región Metropolitana, los grados varían entre los $19^{\circ} \mathrm{C}$ y $20^{\circ} \mathrm{C}$ en las localidades de manglares, con baja altitud y alta presión atmosférica, siendo consideradas las áreas más cálidas del territorio. En los puntos más altos hacia el interior de la parte continental los promedios anuales están entre los $16^{\circ} \mathrm{C}$ y $17^{\circ} \mathrm{C}$ (Figura 6.11). 


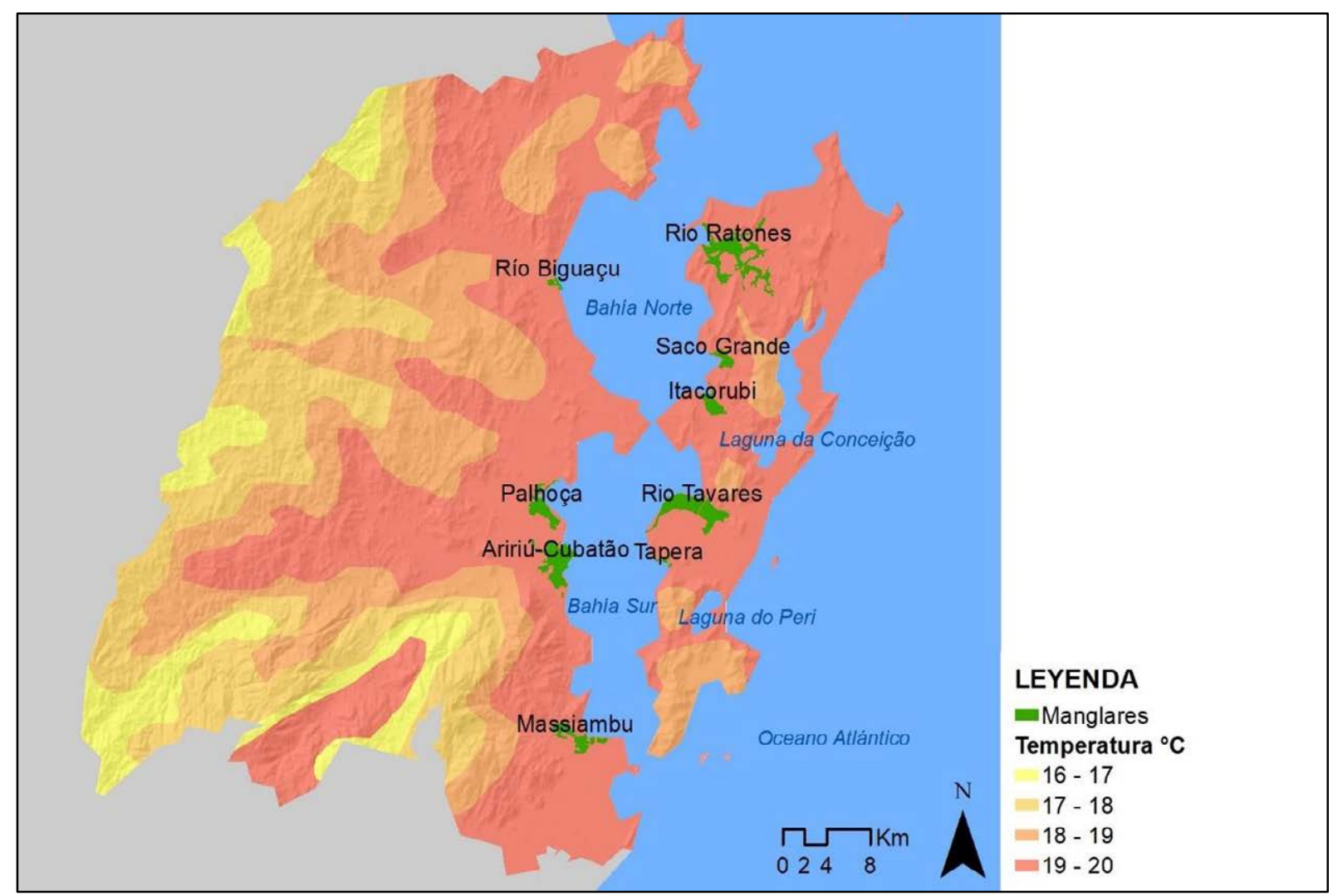

Figura 6.11: Promedios de temperaturas anuales. Fuente: Elaboración propia con los datos de Pandolfo et al. (2002).

En los sitios de manglares, los promedios mínimos de temperaturas anuales registran entre los $15^{\circ} \mathrm{C}$ y $16^{\circ} \mathrm{C}$ y los promedios máximos de temperaturas anuales apuntan entre los $26^{\circ} \mathrm{C}$ y $27^{\circ} \mathrm{C}$, con humedad relativa anual alta, alrededor de los $82 \%$ y $84 \%$ (Padolfo et al., 2002). En esta zona, se verifica también una precipitación entre los $1.500 \mathrm{~mm}$ y $1.900 \mathrm{~mm}$ anuales bien distribuidos anualmente, como se muestra en la Figura 6.12. 


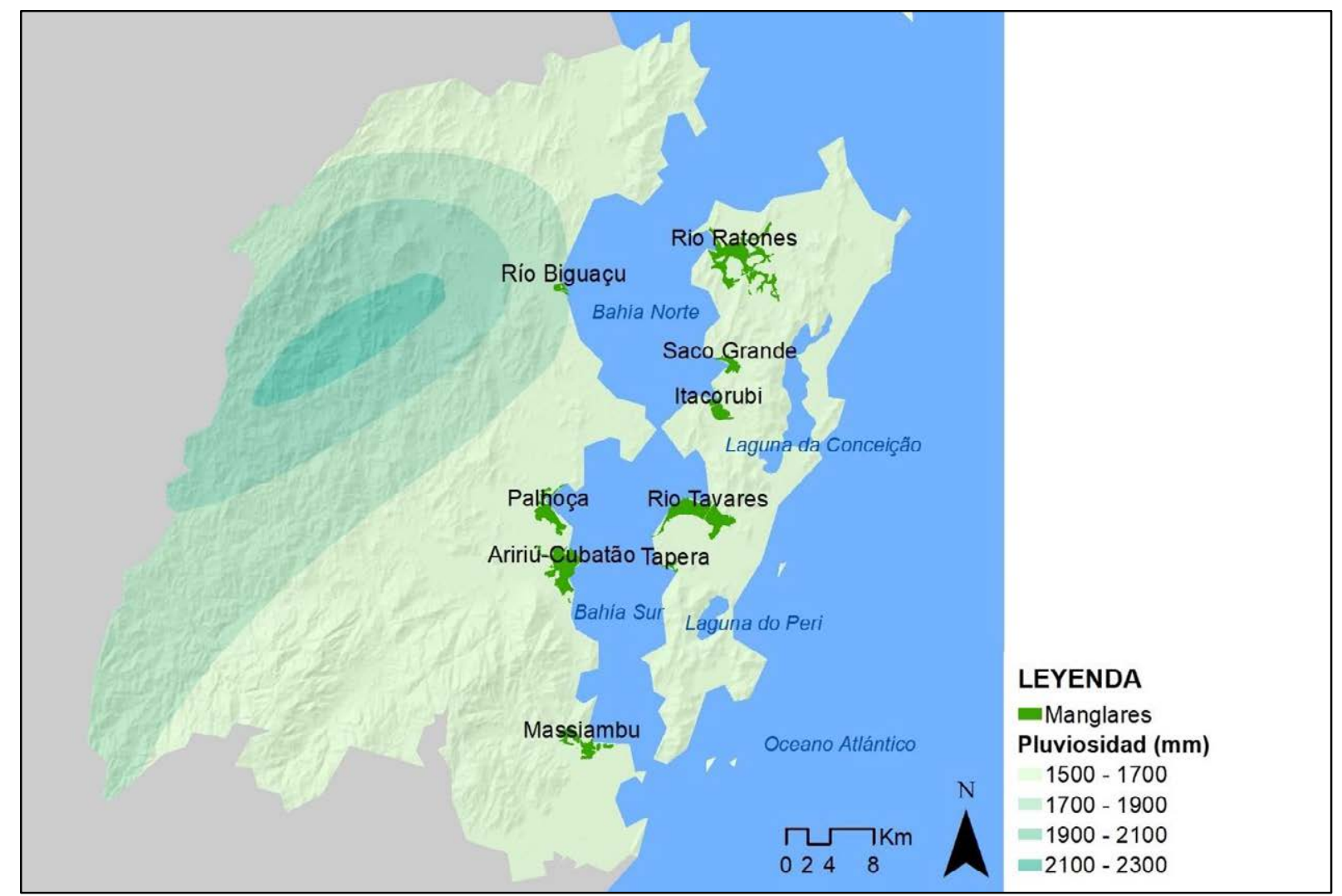

Figura 6.12: Pluviosidad anual. Fuente: Elaboración propia con los datos de Pandolfo et al. (2002).

De acuerdo con la Figura 6.13, se puede observar que los promedios máximos de temperaturas anuales, en los meses correspondientes al verano, tienen relación con el aumento de la precipitación. Las cifras de días lluviosos en los meses más cálidos se sitúan entre los 8 y 14 días, y en los meses más fríos, entre los 6 y 8 días (Pandolfo et al., 2002).

En cuanto a los vientos registrados (Figura 6.14), apuntan una mayor velocidad en los meses más cálidos. De acuerdo con Nimer (1989, p. 251), en los periodos de altas temperaturas (primavera y verano) son frecuentes los vientos del cuadrante Norte y en los periodos de bajas temperaturas (otoño e invierno), del cuadrante Sur. 


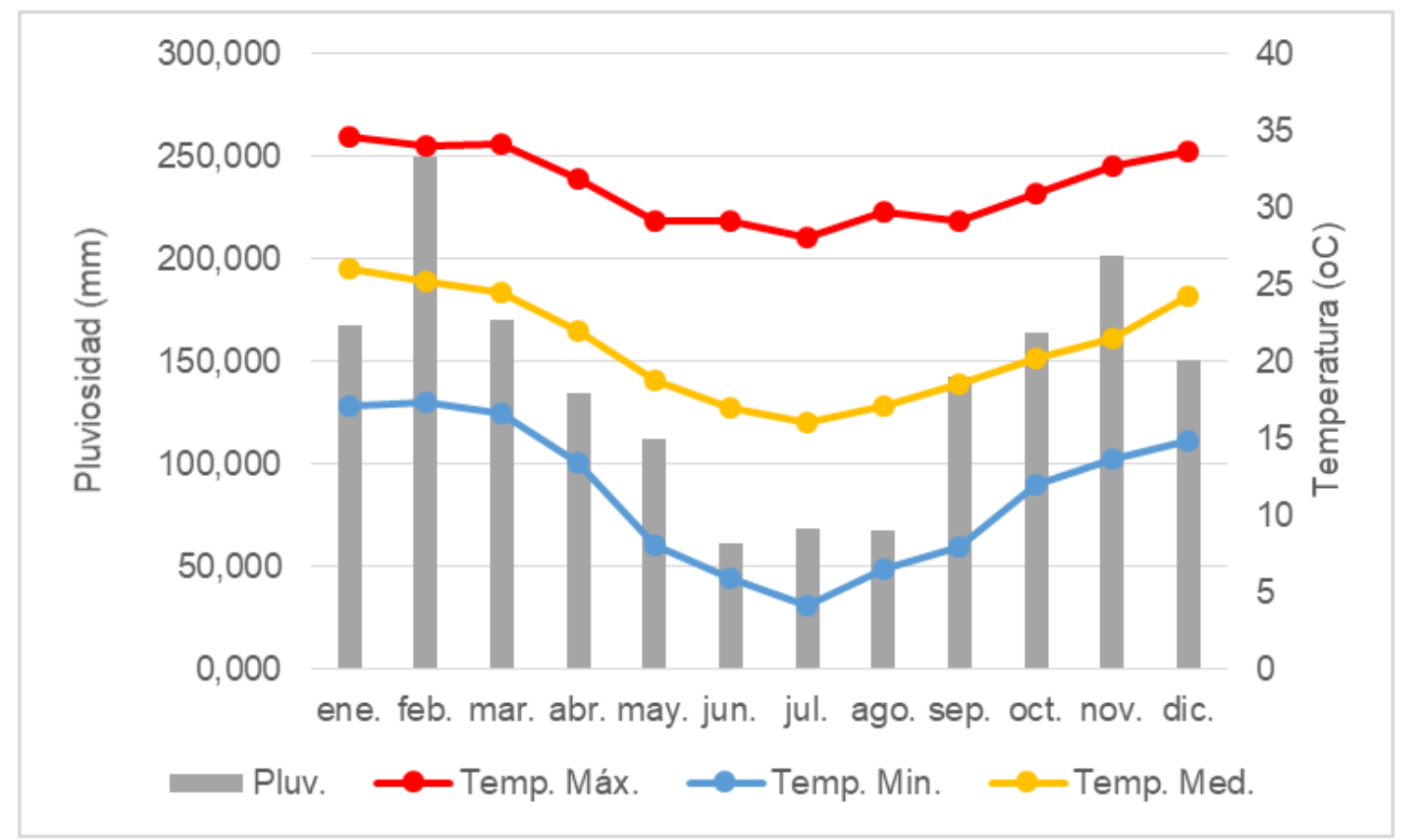

Figura 6.13: Promedios de pluviosidad y de temperatura en el Municipio de Florianópolis, entre los años de 1998 y 2008. Fuente: Elaboración propia a partir de PMISB (2010, p. 18 y 19), con los datos del Centro de Informação de Recursos Ambientais e de Hidrometeorologia de Santa Catarina (CIRAM).

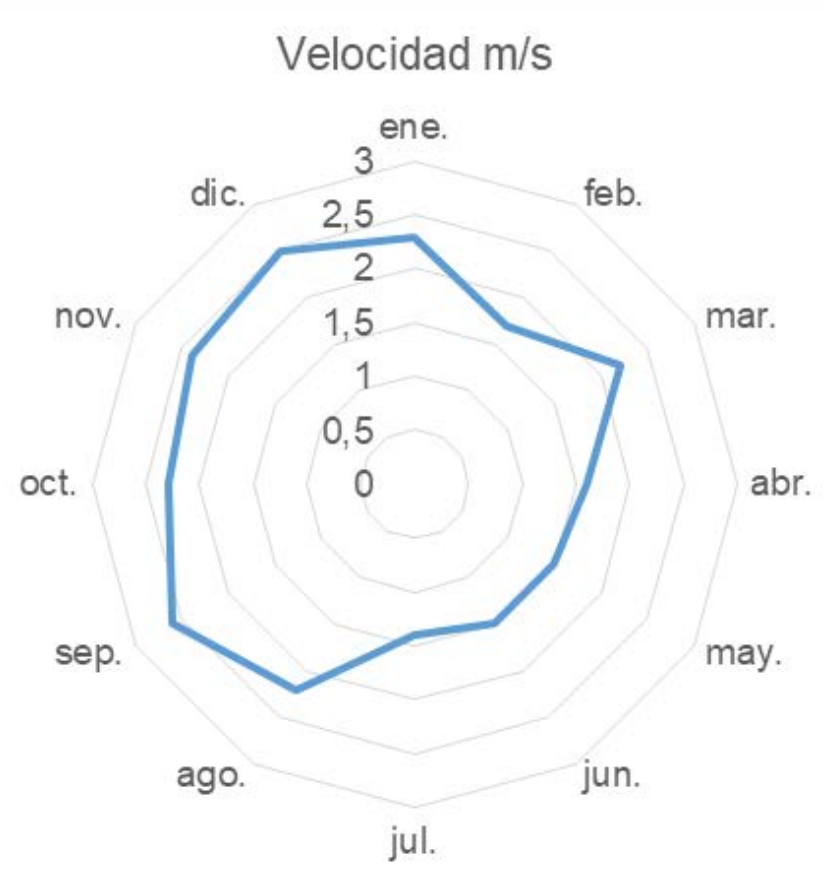

Figura 6.14: Promedios de la velocidad de los vientos en el Municipio de Florianópolis, entre los años de 1998 y 2008. Fuente: Elaboración propia a partir de PMISB (2010, p. 18 y 19), con los datos de CIRAM.

Los fenómenos climáticos anormales, conocidos como El Niño Oscilación del Sur (ENOS) y 
La Niña, también influyen en el clima de la Región Metropolitana. Ambos representan un cambio del sistema océano-atmósfera en el Océano Pacífico Tropical, que tienen consecuencias en el clima en todo el planeta.

El Niño es un fenómeno caracterizado por un calentamiento anormal de las aguas superficiales del Océano Pacífico Tropical. Según el Centro de Previsão de Tempo e Estudos Climáticos e Instituto Nacional de Pesquisas Espaciais (CPTEC-INPE) ${ }^{30}$, este evento puede actuar en el clima regional y global, modificando los patrones de viento a nivel global, y afectando a los regímenes de lluvia en las regiones tropicales y latitudes promedias. La ocurrencia de El Niño en el Sur de Brasil se caracteriza por el calentamiento de las aguas del Océano Pacífico, que asociado con las del Atlántico Sur, origina las lluvias intensas.

La Niña representa un fenómeno atmosférico oceánico con aspectos opuestos al EI Niño, que se caracteriza por un anormal enfriamiento de las aguas superficiales del Océano Pacífico Tropical (CPTEC-INPE) ${ }^{31}$. En el Sur de Brasil este fenómeno conlleva fuertes lluvias o sequía prolongada.

En época de gran pluviosidad, numerosas veces los fenómenos considerados normales dentro de la clasificación climática también se confunden con los efectos de El Niño y La Niña. La ocurrencia de estos fenómenos, generalmente, tiende a alternarse cada 3 - 7 años, aunque también puede variar entre 1 y 10 años (CPTEC-INPE) ${ }^{32}$. Sin embargo, según Nobre (2010), la evidencia científica reciente apunta a una intensificación de la variabilidad climática asociada con El Niño y La Niña debido al calentamiento global.

El debate sobre el calentamiento global producido por el efecto invernadero ha reflejado una gran preocupación sobre el cambio climático a nivel local y global. Según las proyecciones del Intergovernmental Panel on Climate Change (IPCC) para América del Sur, se muestra un aumento de la temperatura de aproximadamente $4^{\circ} \mathrm{C}$ para la década de 2080 en el Sur de América del Sur (escenarios de alta emisión de gases de efecto invernadero) (Nobre, 2010).

El Ciclón Extratropical, conocido como Huracán Catarina, se está especulando como una de las causas del cambio climático, debido a la alta temperatura de las aguas del Océano Atlántico. El evento afectó a la costa del Sur de Brasil, incluyendo la Región Metropolitana de Florianópolis, en marzo de 2004. Fue diagnosticado como clase 2, con vientos de entre 154 y

\footnotetext{
${ }^{30}$ CPTEC-INPE, Centro de Previsão de Tempo e Estudos Climáticos e Instituto Nacional de Pesquisas Espaciais. Disponible en http://enos.cptec.inpe.br/elnino/pt (fecha de consulta: junio de 2016).

31 Ídem.

32 Ibídem.
} 
$177 \mathrm{~km} / \mathrm{h}$, conforme la escala de Saffir-Simpson, utilizado por la National Oceanic and Atmospheric Administration (NOAA) ${ }^{33}$ para clasificar la intensidad de los vientos de los huracanes. Sin embargo, el Huracán Catarina superó la clase 2, impulsado hasta 180 km/h.

De acuerdo con el investigador Carlos Nobre $^{34}$, el Huracán Catarina fue el primer huracán observado en el Atlántico Sur, a pesar de que el sistema de observación de Brasil es todavía muy reciente, con cincuenta años desde ese evento. También señala que el calentamiento global provoca que los fenómenos meteorológicos extremos ocurran con más frecuencia y/o más intensidad.

\subsubsection{Hidrografía}

La Región Metropolitana de Florianópolis está formada por la Región Hidrográfica de la Costa Central, perteneciente al sistema de Vertiente Atlántico, que se sitúa en la zona central de la costa del Estado de Santa Catarina. La Región Hidrográfica de la Costa Central se conforma en 4 cuencas hidrográficas que son: del Río da Madre, del Río Cubatão, del Río Biguaçu y del Río Tijucas (Figura 6.15).

\footnotetext{
33 NOAA, National Oceanic and Atmospheric Administration. Disponible en http://www.nhc.noaa.gov/aboutsshws.php (fecha de consulta: septiembre de 2016)

${ }^{34}$ Entrevista concedida a IHU On-Line (Instituto Humanistas Unisinos), en diciembre de 2008. Disponible en http://www.ihu.unisinos.br/ (fecha de consulta: junio de 2016).
} 


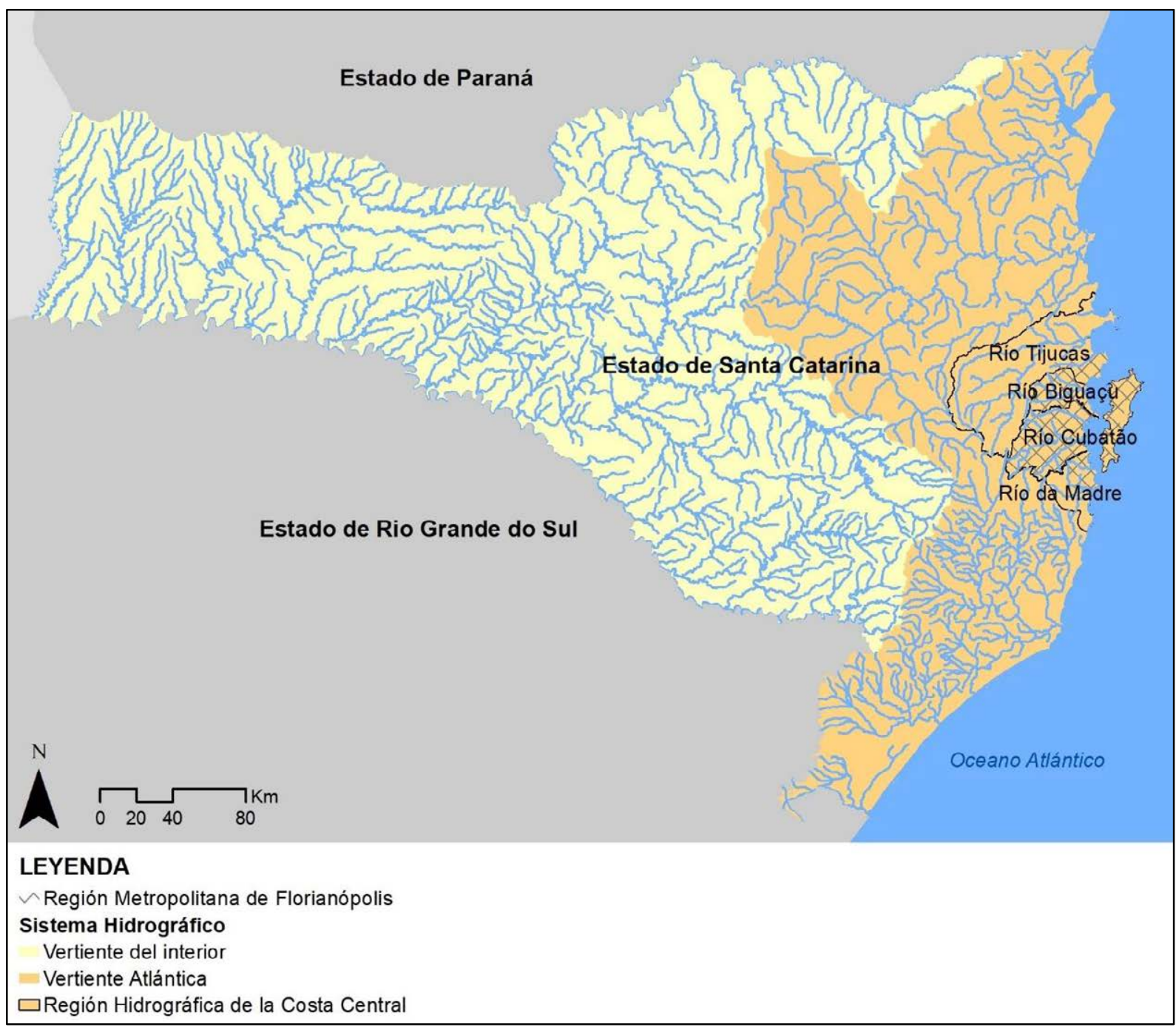

Figura 6.15: Sistema Hidrográfico. Fuente: Elaboración propia con los datos de la Secretaria de Desenvolvimento Urbano e Meio Ambiente, SDM (1997) ${ }^{35}$.

Además de las cuencas hidrográficas, hacen parte las microcuencas, que son las pequeñas cuencas hidrográficas. Las mayores áreas de microcuencas de la isla están volcadas hacia las Bahías Norte y Sur. Destacan la del Río Ratones y del Río Tavares, donde se encuentran también los mayores manglares de la parte insular (Municipio de Florianópolis). En el lado continental sobresale la microcuenca del Río Maruim y del Río Massiambu Grande, en el Municipio de Palhoça (Figura 6.16 y Tabla 6.2).

35 Mapa digital disponible en http://ciram.epagri.sc.gov.br (fecha de consulta: abril de 2016). 


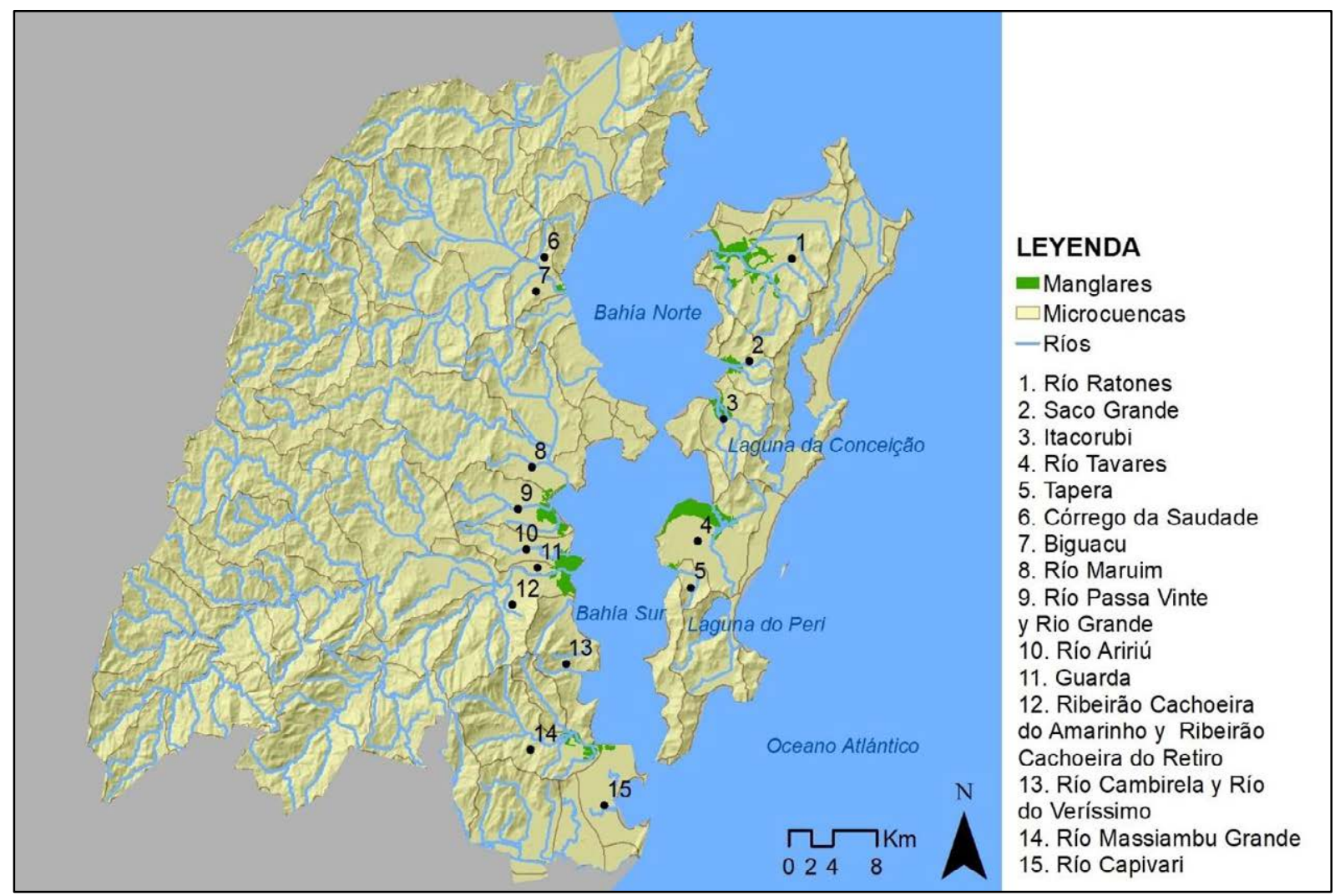

Figura 6.16: Microcuencas. Fuente: Elaboración propia con los datos de Epagri (2007) ${ }^{36}$.

\begin{tabular}{|c|c|c|c|}
\hline Microcuencas & Áreas $\left(\mathrm{Km}^{2}\right)$ & Río Principal & Manglares \\
\hline 1. Río Ratones & 116,24 & Río Ratones & Manglar del Río Ratones \\
\hline 2. Saco Grande & 17,19 & Río Vadik & Manglar de Saco Grande \\
\hline 3. Itacorubi & 28,27 & Río Itacorubi & Manglar de Itacorubi \\
\hline 4. Río Tavares & 49,99 & Río Tavares & $\begin{array}{l}\text { Manglar del Río Tavares y } \\
\text { Manglar de Tapera }\end{array}$ \\
\hline 5. Tapera & 7,37 & Río Alto Ribeirão & Manglar de Tapera \\
\hline 6. Córrego da Saudade & 8,39 & Río Biguaçu & \multirow{2}{*}{ Manglar del Río Biguaçu } \\
\hline 7. Biguacu & 13,99 & Río Biguacu & \\
\hline 8. Río Maruim & 113,25 & Río Maruim & \multirow{2}{*}{ Manglar de Palhoça } \\
\hline 9. Río Passa Vinte y Rio Grande & 37,02 & Río Passa Vinte & \\
\hline 10. Río Aririú & 23,57 & Río Aririú & \multirow{3}{*}{ Manglar de Aririú-Cubatão } \\
\hline 11. Guarda & 9,96 & Río Cubatão & \\
\hline $\begin{array}{l}\text { 12. Ribeirão Cachoeira do Amarinho y } \\
\text { Ribeirão Cachoeira do Retiro }\end{array}$ & 52,57 & Río Cubatão & \\
\hline 13. Río Cambirela y Río do Veríssimo & 38,08 & Río Cambirela & \multirow{3}{*}{ Manglar de Massiambu } \\
\hline 14. Río Massiambu Grande & 57,55 & Río Massiambu Grande & \\
\hline 15. Río Capivari & 28,58 & Río Capivari & \\
\hline
\end{tabular}

Tabla 6.2: Microcuencas y manglares correspondientes. Fuente: Elaboración propia con los datos de Epagri (2007).

${ }^{36}$ Mapa digital disponible en http://ciram.epagri.sc.gov.br (fecha de consulta: abril de 2016). 
Las características de los ríos corresponden a su tipología del relieve. Cuenta con una topografía muy accidentada en la parte de mayor altitud. En la parte de baja altitud sus pendientes están suavizadas, siendo considerada como ríos de Ilanuras (Santa Catarina, 1991, p. 20), según se observa en la Figura 6.17.

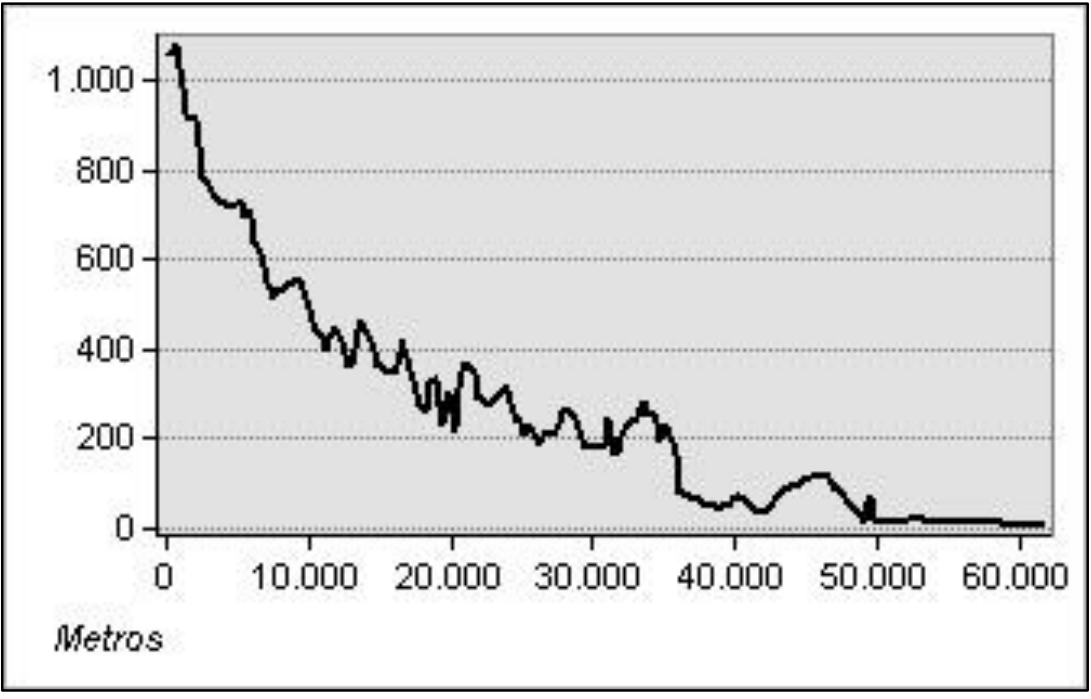

Figura 6.17: Perfil Longitudinal del Río Cubatão. Fuente: Elaboración propia.

Los ríos están comandados por el régimen pluviométrico, caracterizados por lluvias distribuidas a lo largo del año que garantizan su suministro normal (Santa Catarina, 1991, p. 20). Es frecuente el flujo máximo en el verano, cuando la lluvia es más intensa, con mayor probabilidad de inundaciones. Ésta es una preocupación importante, teniendo en cuenta el avance de la urbanización hacia las zonas sujetas a inundaciones, especialmente en los sitios de manglares.

Los manglares de la Región Metropolitana, mediante su desarrollo en las microcuencas, se denominan marítimo-fluviales, pues favorecen el flujo lento del agua de los ríos, siendo importantes para la estabilización de los ríos en los mares (Sevegnani y Schroeder, 2013, p. 132). Asimismo, la inundación provocada por las mareas altas en los ríos tiene la función de producir el sustrato de los manglares a través del intercambio de agua. Por lo tanto, el papel de estos ríos en los manglares es de suma importancia para su mantenimiento.

\subsubsection{Componentes bióticos}

Los componentes bióticos de la Región Metropolitana de Florianópolis corresponden a la diversidad de la flora y la fauna local y están estrechamente ligados a las características físicas del ambiente (factores abióticos). Hay básicamente tres representaciones forestales nativas 
en el territorio: la Selva Ombrófila Densa, la Selva Ombrófila Mista y la Formación Pionera (restinga y manglares), pertenecientes al bosque de la Mata Atlántica ${ }^{37}$. Estas vegetaciones están divididas en vegetaciones remanentes (consideradas como vegetaciones originales o en periodo más avanzado de regeneración, que se asemejan a las vegetaciones originales) o vegetaciones secundarias (en fase de regeneración por la deforestación). Están desarrolladas en las secciones siguientes y verificadas en las Figuras 6.18 y 6.19 .

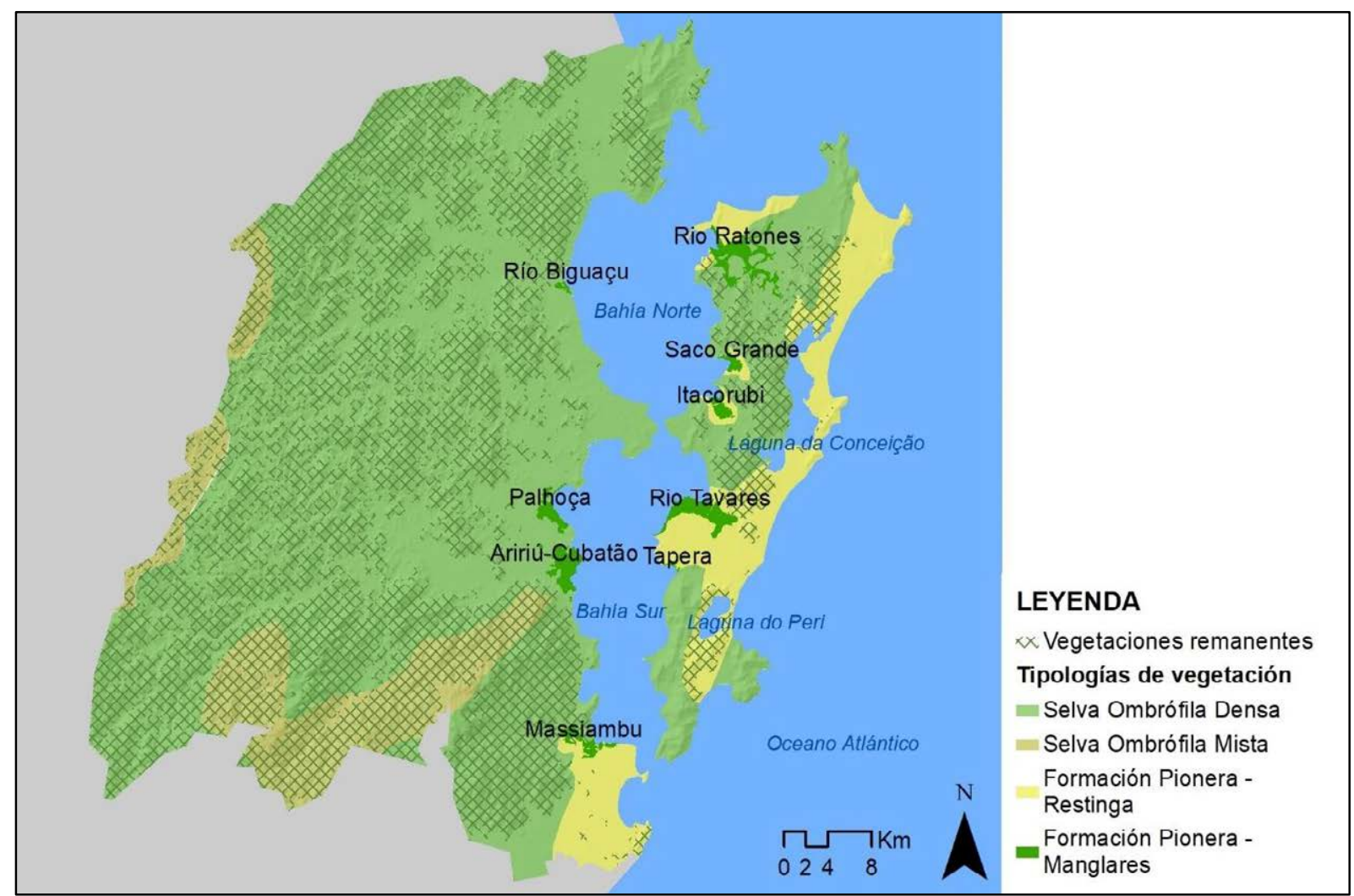

Figura 6.18: Distribución de la vegetación. Fuente: Elaboración propia con los datos de SAR (2005) y Klein $(1978)^{38}$.

\footnotetext{
37 Demostrada en la sección 3.2.3.

38 Mapa digital disponible en http://ciram.epagri.sc.gov.br (fecha de consulta: abril de 2016).
} 


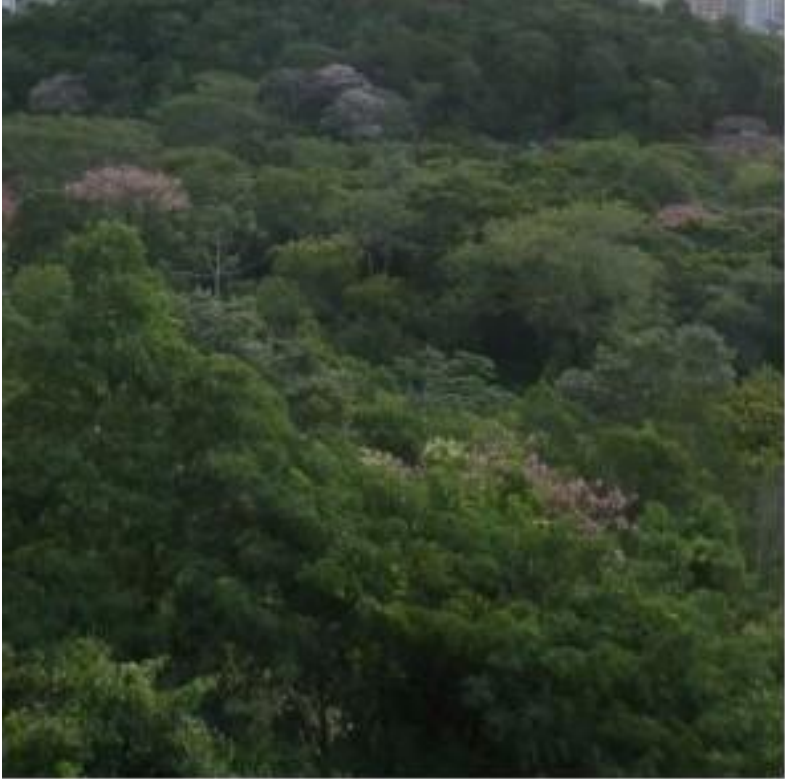

Vegetación Ombrófila Densa

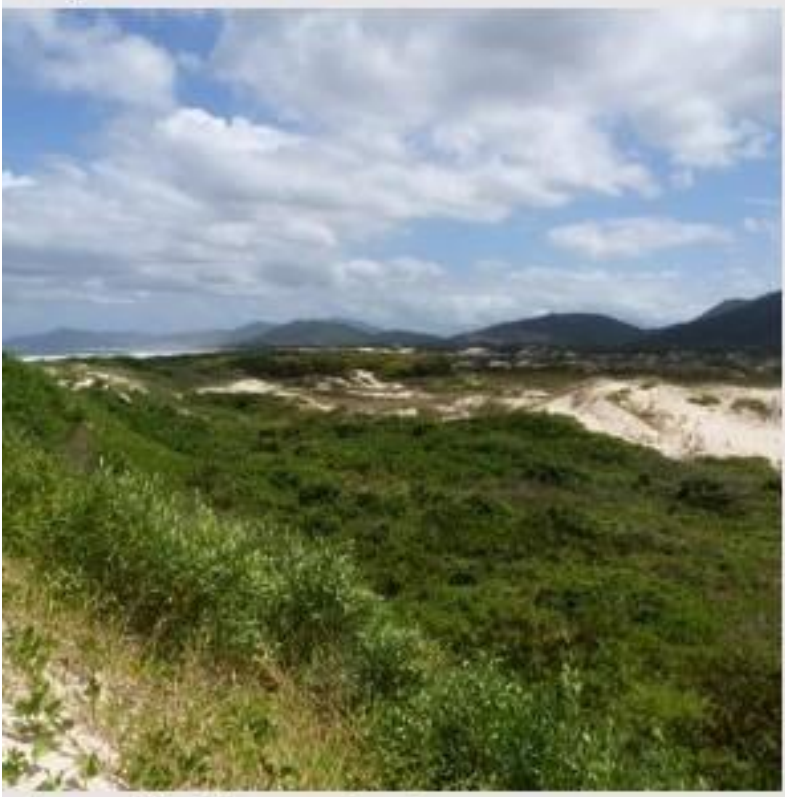

Formación Pionera - Restinga

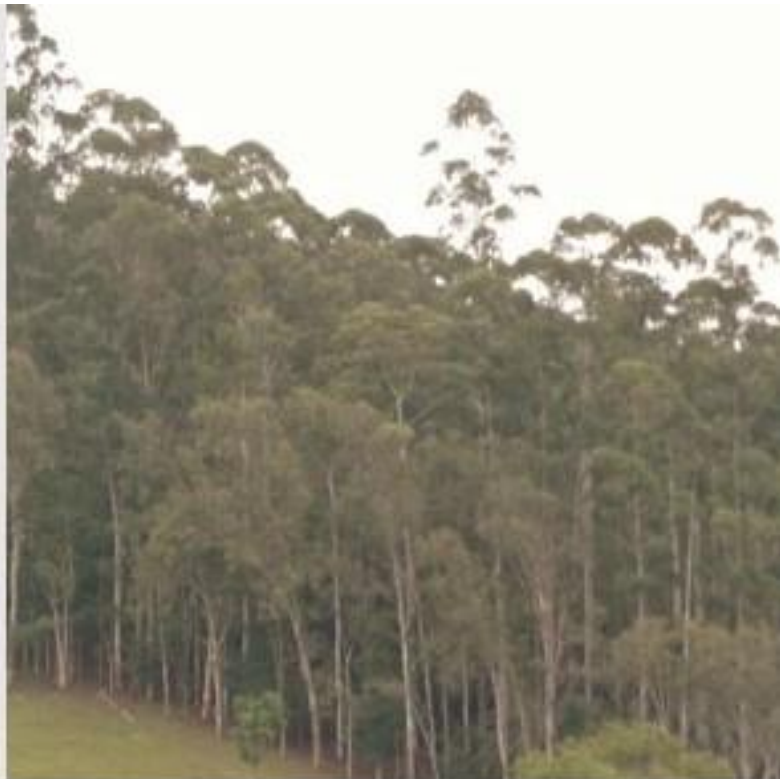

Vegetación Ombrófila Mista

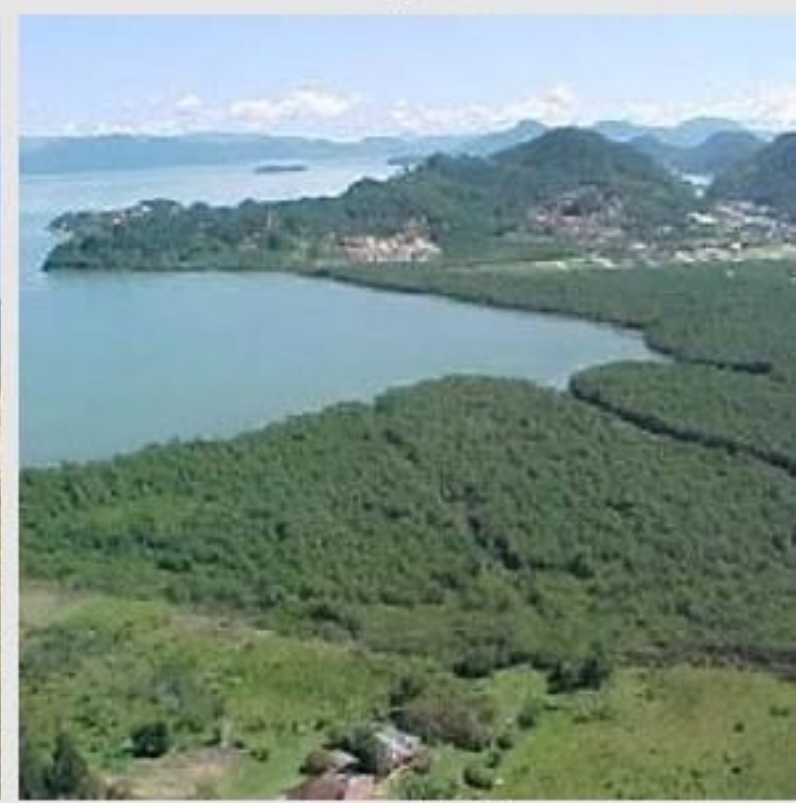

Formación Pionera - Manglares

Figura 6.19: Tipologías de vegetación. Fuente: Vegetación Ombrófila Densa, Mista y Restinga - Archivo de la autora (2017); Manglares - IBAMA (2003, p. 6, cap. 5).

Además de las tipologías de las vegetaciones demostradas, también es importante tener en cuenta la existencia de la plantación de especies exóticas en el territorio, con bosques principalmente de pinos y eucaliptos.

\subsubsection{Selva Ombrófila Densa}

La Selva Ombrófila Densa, o popularmente llamada de Pluvial Tropical, ocupa una gran área 
de la Región Metropolitana de Florianópolis. Está relacionada con las características de clima tropical, con altas temperaturas y altas precipitaciones, en las altitudes más bajas de sierra y zonas de llanura. Entre sus atributos, está considerada como una tipología de vegetación exuberante, compuesta de diversos agrupamientos distintos en cuanto a su composición, estructura y aspecto vegetativo (Klein, 1978, p. 3).

Está formada por grandes árboles, entremediadas de diversas especies de árboles más pequeños, además de arbustos y vegetación herbácea (Klein, 1978, p. 3). Hay una gran cantidad de epífitas (planta que crece sobre otro vegetal usándolo solamente como soporte) y lianas (se mantienen enraizadas durante toda su vida y necesitan de un soporte para mantenerse erectas). De acuerdo con Sevegnani y Schroeder (2013, p. 97), todo este conjunto ejerce una importante cubierta para el suelo, que alberga diversas especies de animales y microorganismos.

Esta vegetación presenta variaciones de altura en relación a la altitud. En las zonas de sierra (más de 100 metros de altitud), llega a medir más de 30 metros de altura, y en las zonas de llanura (menos de 30 metros de altitud), entre los 15 y 20 metros. En la cima de las montañas más altas y pendientes acentuadas la vegetación se desarrolla menos debido a las condiciones climáticas y del suelo (Sevegnani y Schroeder, 2013, p. 101).

Los animales de esta selva son numerosos, algunos permanecen todo el año en su lugar, otros migran hacia las zonas de más bajas altitudes durante el invierno (Sevegnani y Schroeder, 2013, p. 101). Hay una diversidad muy grande en relación a los mamíferos, aves, reptiles y anfibios. A pesar de tener una gran diversidad biológica, se trata de una flora casi extinguida y la fauna en peligro de extinción debido la ocupación del suelo en estas áreas.

\subsubsection{Selva Ombrófila Mista}

La Selva Ombrófila Mista se encuentra en una pequeña porción en la parte Oeste de la Región Metropolitana y otra porción al Sur, con menos variedades de especies de flora, en comparación con la Selva Pluvial Tropical. Está situada en las zonas más elevadas (a partir de los 500 y 600 metros de altitud), con clima menos cálido, caracterizada como bosques subtropicales templados.

Está compuesta de especies de angiospermas y coníferas. De acuerdo con las investigaciones de Klein (1978, p. 10), posee dos tipologías: la Selva de Araucaria o Pinhal y la Selva Faxinal. La Selva Faxinal es la que compone la Región Metropolitana, con árboles distribuidos de forma dispersa y menos densa. Se representa como una vegetación de 
transición entre la Selva Ombrófila Densa y la Selva de Araucaria (Klein, p. 14). Así como ha ocurrido en la Selva Ombrófila Densa, esta vegetación también ha producido bastante deforestación.

\subsubsection{Formación Pionera}

La Formación Pionera es un ecosistema que hace la conexión con la Selva Ombrófila Densa. Está constituida por especies de ambientes de formación rocosa reciente, de lugares inestables y sometidos a tensiones naturales. Esta formación se puede clasificar en dos categorías: la vegetación de restinga (influencia marina) y la vegetación de manglares (influencia marítimo-fluvial).

Restinga es un término utilizado en Brasil para denominar las vegetaciones de suelos arenosos, con mucha salinidad y pobres de materia orgánica, adaptada a la acción del viento, las temperaturas elevadas y la radiación solar. Posee una estructura arbustiva y herbácea con raíces profundas, formando densos agrupamientos para protegerse de los factores limitantes. A diferencia de la restinga, la vegetación de manglares se ubica en los ambientes de suelos limosos. Por ser un ambiente muy susceptible a inundaciones, cuenta con una flora muy especializada, lo que reduce las comunidades de especies existentes.

\subsubsection{Vegetación secundaria}

La vegetación secundaria fueron áreas deforestadas, en gran parte por la agricultura, y que, actualmente, están en fase de regeneración por el abandono de la práctica agrícola y ganadera en estas áreas. Según Klein (1969, p. 7), una gran área de estos bosques fue devastada principalmente en las partes de bajas pendientes y en las Llanuras Cuaternarias, dejándolos intactos en los puntos de más difícil acceso.

En la Región Metropolitana, la vegetación secundaria todavía puede estar en diferentes etapas de plantación, que se clasifican como: Capoeirinha, Capoeira y Capoeirão, demostradas en la Figura 6.20. 


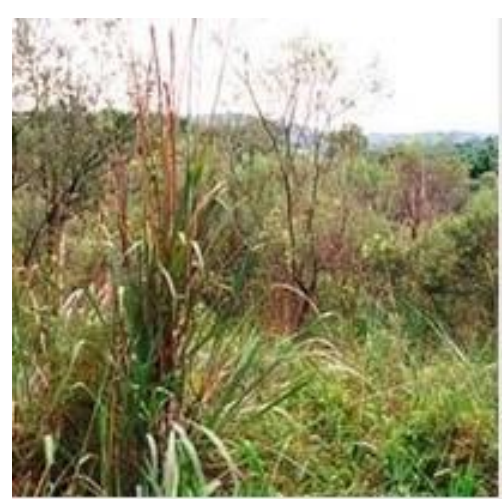

\section{Etapa Capoeirinha o periodo inicial de plantación}

Tiempo: viene después del abandono de una zona agrícola o de ganadería. Esta etapa se extiende generalmente hasta seis años y, en algunos casos, pueden durar hasta diez años, dependiendo del grado de degradación del suelo o la escasez de semillas.

Estructura: La altura promedio de los árboles es de $4 \mathrm{~m}$, con $8 \mathrm{~cm}$ diámetro.

\section{Etapa Capoeira o periodo intermedio de plantación}

Tiempo: surge a partir de los seis años, con una duración de hasta 15 años.

Estructura: los árboles alcanzan una altura promedia entre $12 \mathrm{~m}$ y $15 \mathrm{~cm}$ de diámetro. La diversidad biológica aumenta, pero todavía hay un predominio de especies de árboles del periodo inicial.

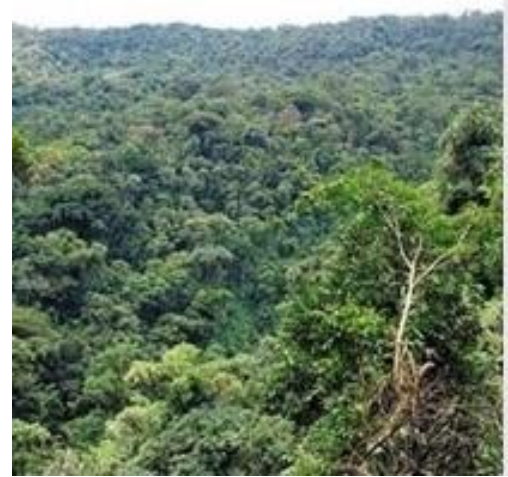

\section{Etapa Capoeirão o periodo avanzado de plantación}

Tiempo: en general comienza a partir de los 15 años y puede llevar de 60 a 200 años para alcanzar de nuevo la etapa similar de la vegetación original.

Estructura: la altura promedio de los árboles es más de $12 \mathrm{~m}$ y el diámetro promedio es superior a $15 \mathrm{~cm}$.

Figura 6.20: Etapas de vegetación secundaria para especies de la Selva Ombrófila Densa. Fuente: Fotos de la Associação de preservação do meio ambiente e da vida, Apremavi ${ }^{39}$ y caracterizadas de acuerdo con PMISB (2010, p. 94 y 95).

Para ejemplificar el sistema de regeneración de estos bosques, la Figura 6.21 ilustra el procedimiento del ciclo adaptativo, que consta de cuatro fases: la reorganización, el crecimiento, la conservación y el colapso (Holling, 1986).

\footnotetext{
${ }^{39}$ Apremavi, Associação de preservação do meio ambiente e da vida. Disponible en http://www.apremavi.org.br/
} (fecha de consulta: julio de 2016). 


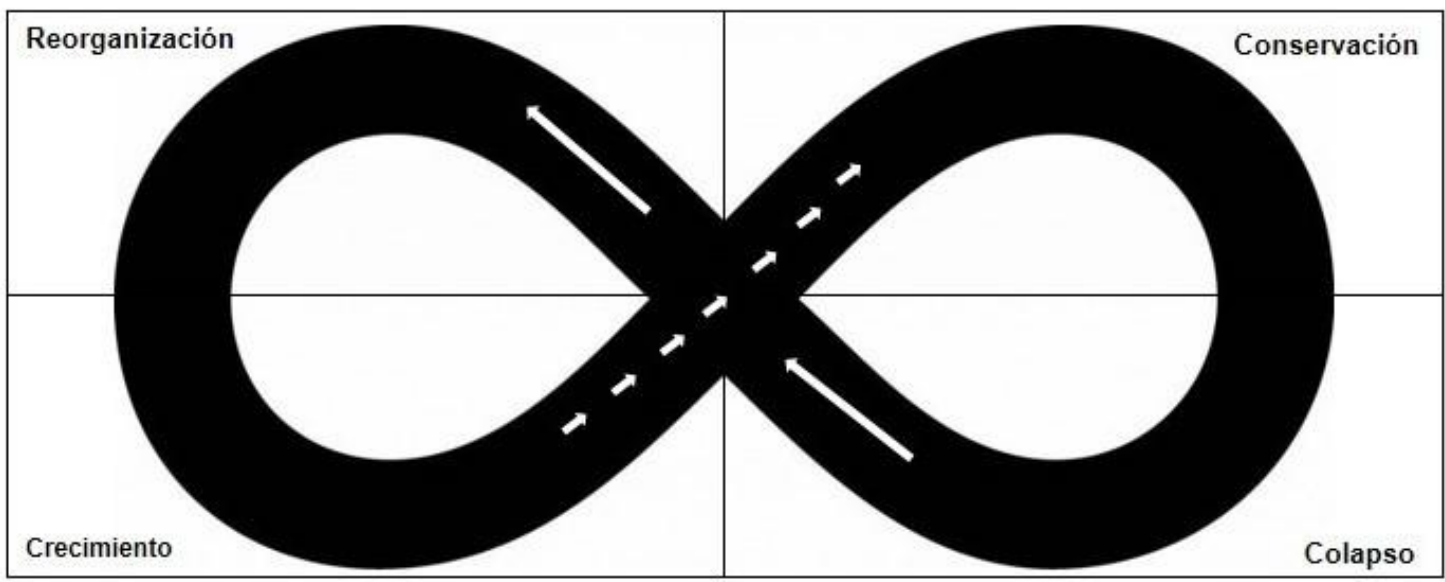

Figura 6.21: Ciclo adaptativo. Fuente: Elaboración propia a partir de Holling y Gunderson (2002).

Estas fases corresponden a un ciclo de adaptación de un ecosistema. La fase que va desde el crecimiento a conservación, son los periodos de regeneración que, en el caso de la Región Metropolitana de Florianópolis, es la vegetación secundaria en las etapas de Capoeirinha, Capoeira y Capoeirão. La fase de colapso hasta la fase de reorganización, se denota una deforestación e inicio de colonización de especies. Las flechas indican la velocidad del cambio en el ciclo, donde las pequeñas flechas apuntan los cambios lentos, mientras que las fechas largas son los cambios rápidos. Por lo tanto, el crecimiento y la conservación son procesos mucho más lentos que el colapso y la reorganización.

Se observa, sin embargo, que este sistema presenta dos aspectos: de resiliencia (colapso y reorganización) y de resistencia (crecimiento y conservación). Esta afirmación es reconocida por Gunderson (2000), quien dice que la resistencia, en términos ecológicos, es la capacidad que un sistema tiene de mantener su estructura y funcionamiento durante una perturbación; diferente de resiliencia, que es la capacidad de un sistema restablecer el equilibrio después de que se ha roto por una perturbación.

De acuerdo con la afirmación anterior, los manglares son considerados una vegetación resistente debido a la capacidad de resistir a las interferencias de las mareas. Dependiendo de la intensidad de las interferencias, esta vegetación puede ser reducida. Sin embargo, tienen la capacidad de establecerse de nuevo, con apariencia similar y, muchas veces, con la misma composición de especies y funcionamiento ecológico (Sevegnani y Schroeder, p. 47). Así que, además de resistentes, se consideran también resilientes. 


\subsubsection{Flora de los manglares}

La flora de los manglares de la Región Metropolitana de Florianópolis se compone de tres especies diferentes: Avicennia schaueriana, Laguncularia racemosa y Rizophora mangle. La formación de estos manglares depende de los aspectos abióticos, tales como el tipo de suelo, la cantidad de lluvia y la variación de las mareas (Sevegnani y Schroeder, 2013, p. 131), que influyen en relación a su desarrollo y tienen características específicas de la misma especie de bosque para distintas regiones. Sin embargo, según Citrón y Schaefer Novelli (1981, p. 23), las especies de los manglares de esta localidad poseen un grado de desarrollo notable a pesar de su proximidad al límite latitudinal.

Cada especie particular de manglar constituye diferentes aspectos para adaptarse al entorno marítimo-fluvial en el cual se desarrollan. Según Sanches Dalotto (2003, p. 40), estos aspectos se relacionan principalmente a través de tres atributos básicos, como la adaptación de las raíces, la tolerancia a la sal y la forma de reproducción. En las Figuras 6.22, 6.23 y 6.24 siguientes se muestran las diferentes especies de manglares, caracterizadas en relación a su estructura, cantidad, ubicación, raíces, salinidad, temperatura y reproducción, citadas por variados autores (Coura Neto y Klein, 1991; Citrón y Schaefer Novelli, 1981; Sánchez Dalotto, 2003; Sevegnani y Schroeder, 2013). 

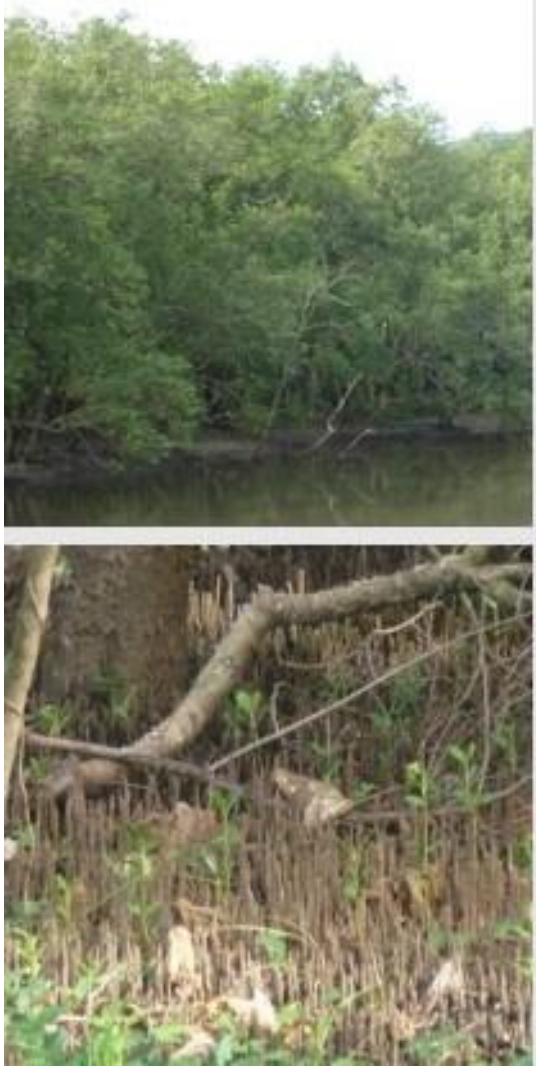

\section{Especie Avicennia schaueriana o manglar negro}

Estructura: es la especie más desarrollada, con altura de 5,6 a 8,4 metros (datos referente al manglar de Itacorubi). La copa es menos densa en relación a las otras especies de manglares.

Cantidad: es la especie más abundante.

Ubicación: se encuentra en la zona de mareas medianas, en el área interior del manglar.

Raices: tiene raíces respiratorias (neumatóforos) con geotropismo negativo, que se eleva por encima del agua para poder respirar, alcanzando de $10 \mathrm{~cm}$ a $15 \mathrm{~cm}$ (datos referentes a los manglares del Río Ratones, de Saco Grande, de Itacorubi y del Río Tavares).

Salinidad: es resistente a la alta salinidad, presentando en sus hojas glándulas responsables por la excreción de la sal.

Temperatura: soporta las temperaturas bajo cero, teniendo condiciones de sobrevivir en las temperaturas más frías de las regiones subtropicales.

Reproducción: se reproduce por medio de propágalos (parte del mismo organismo capaz de desarrollarse de manera separada, dando origen a un nuevo individuo).

Figura 6.22: Avicenia schaueriana. Fuente: Fotos del archivo de la autora (2017).
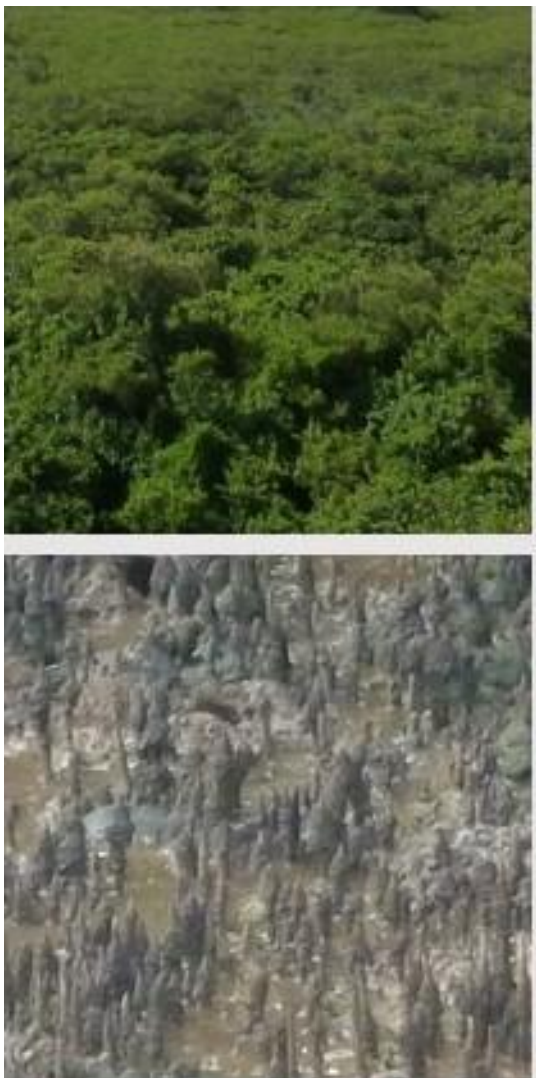

\section{Especie Lagunlaria racemosa o manglar blanco}

Estructura: es la especie de menor estructura, que varía alrededor de los 3 metros de altura (datos referentes al manglar de Itacorubi).

Cantidad: es la segunda en cantidad.

Ubicación: ocupa la zona menos inundada por las mareas, siendo un tipo de manglar que prevalece en la periferia 0 , incluso, a lo largo de canales de agua salobre.

Raices: presenta raices respiratorias con geotropismo negativo, pero menos desarrolladas comparadas con las raíces de la especie Avicenia schaueriana.

Salinidad: es poco tolerante.

Temperatura: es poco tolerante a las bajas temperaturas, incluso las áreas sombreadas.

Reproducción: se reproduce por medio de propágalos.

Figura 6.23: Laguncularia racemosa. Fuente: Fotos del archivo de la autora (2017). 

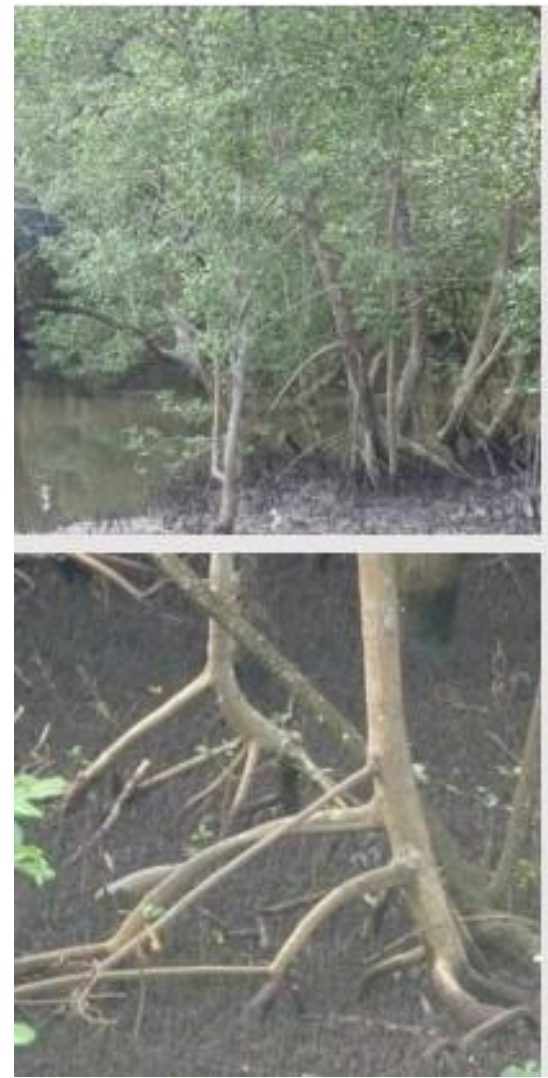

\section{Especie Rizophora mangle o manglar rojo}

Estructura: posee altura de 3 a 4 metros (datos referentes al manglar de Itacorubi).

Cantidad: es la especie más reducida.

Ubicación: soporta la inmersión completa en momentos de inundación, se ubicando en las zonas en contacto con el mar y protegida de las olas, a lo largo de los canales, en la desembocadura de los ríos o en las partes interiores de los estuarios

Raices: presenta raíces respiratorias con geotropismo positivo, cuya base comienza en las partes superiores del tallo, permitiendo la planta se sostener en sustrato no consolidado.

Salinidad: es poco tolerante

Temperatura: es poco tolerante. Debido a esto, la franja límite de su aparición se sitúa en la Región Metropolitana de Florianópolis, aunque es muy común en las regiones tropicales.

Reproducción: se reproduce por medio de propágalos, que crecen por un determinado tiempo adheridos a la planta de origen.

Figura 6.24: Rizophora mangle. Fuente: Fotos del archivo de la autora (2017).

Los manglares de esta localidad también se componen de variadas vegetaciones asociadas. En las áreas más fangosas, entre el mar o río con la especie de manglar Rizophora mangle, se encuentran especies herbáceas, como el ejemplo de la especie Spartina montevidensis (Souza Sobrinho et al., 1969, p. 13). En los suelos poco sujetos a la amplitud de la marea, hay vegetaciones asociadas entre el manglar con la Selva Pluvial Tropical o la vegetación de restinga, predominando especies arbustivas denominadas como Hibiscus tiliaceus var. pernambucensis y Acrostichum aureum (Souza Sobrinho et al., 1969, p. 14). Tanto las especies de manglares, cuando las vegetaciones asociadas forman en general una graduación, que depende del flujo de las mareas (Figura 6.25). 


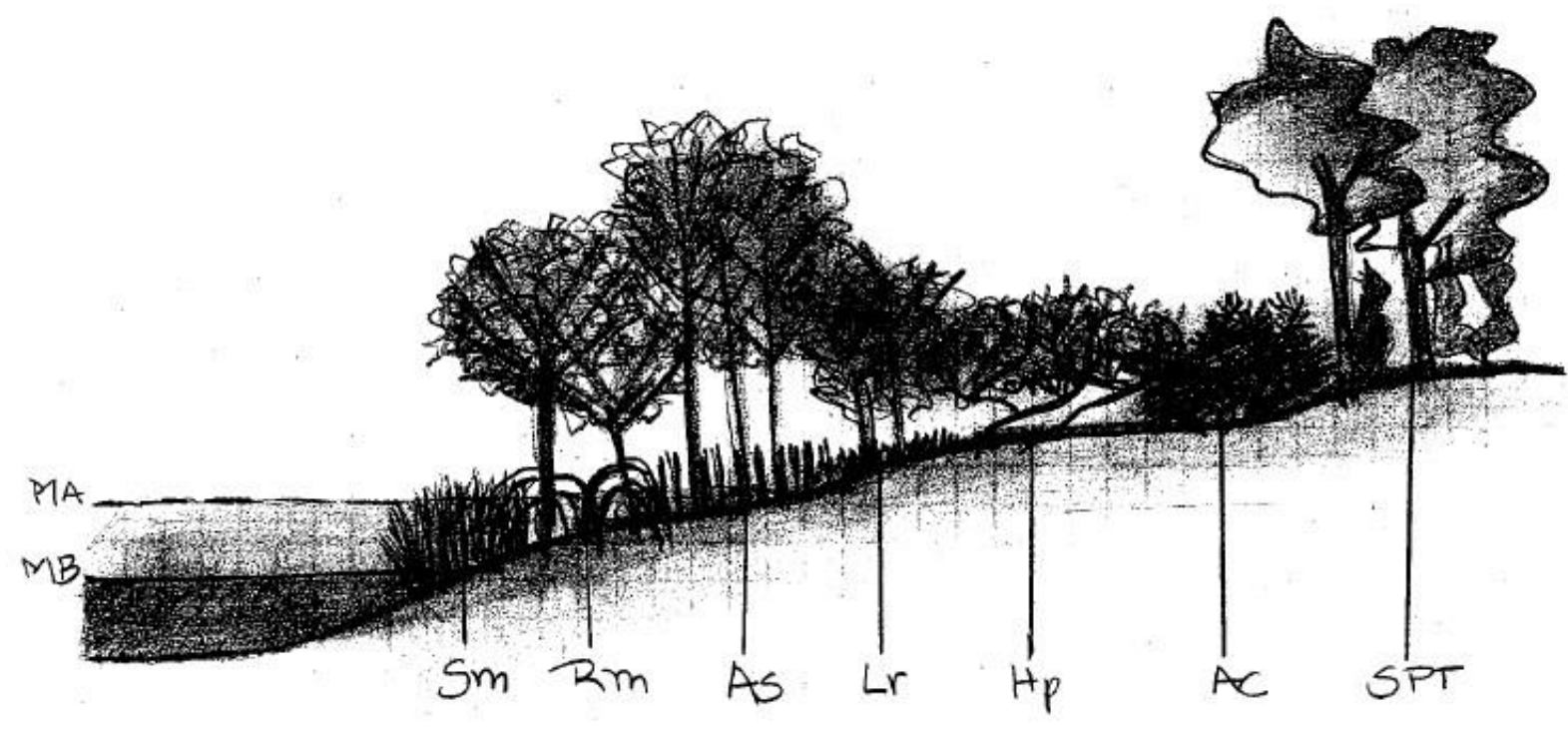

Leyenda: MA: Marea alta, MB: Marea baja, Sm: Spartina montevidensis, Rm: Rizophora mangle, As: Avicenia schaueriana, Lr: Lagunlaria racemosa, Hp: Hibiscus tiliaceus var. pernambucensis, Ac: Acrostichum aureum, SPT: Selva Pluvial Tropical.

Figura 6.25: Perfil de vegetación de manglar con vegetaciones asociadas. Fuente: Elaboración propia a partir de Lamberti (1969, p.49), adaptado para la Región Metropolitana de Florianópolis.

Según Silva (1990, p. 105), muchos autores afirman la existencia de una zonificación establecida en los manglares y la vegetación asociada en forma gradual. Sin embargo, una de las características del estudio del manglar del Río Ratones, hecho por la autora, verifica la falta de zonificación de estas especies, que revela una variación estructural en forma de mosaico y no en forma gradual y continua, probablemente por ser originadas de diferentes épocas de sedimentación, además de las perturbaciones antropogénicas (Silva, 1990, p. 113).

\subsubsection{Fauna de los manglares}

La fauna de los manglares de la Región Metropolitana de Florianópolis es bastante variada. Existe una gran cantidad de invertebrados, tales como gambas, cangrejos, berberechos, crustáceos, moluscos y ostras. Cuenta también con muchas especies de vertebrados de peces, aves, réptiles y mamíferos, venidos de los ambientes terrestres, marinos o de agua dulce. En cuanto a los anfibios, no hay registros, muy probablemente por ser éste un ecosistema con mucha salinidad, una condición no tolerable a los anfibios (IBAMA, 2003, p. 16, cap. 5).

Muchas especies de la fauna de los manglares son de hábitats variados. Las utilizan como ambiente para refugio, alimentación, dormitorio, reproducción y el desarrollo en las primeras etapas de vida, funcionando como un ecosistema de transición en la migración de las especies 
con otros ecosistemas adyacentes. Aunque hay también especies que permanecen en los manglares la totalidad de su ciclo de vida.

Las especies de aves, como el biguá (Phalacrocorax brasilianus), la garça branca grande (Ardea alba) y la garça branca pequena (Egretta thula), utilizan los manglares para nidificación y dormitorio (Naka y Rodrigues, 2000). Asimismo, otras aves los usan solamente para la alimentación durante su migración para otro hábitat, como el maçarico de sobre branco (Calidris fuscicollis), el maçarico de perna amarela (Tringa flavipes) y el maçarico grande de perna amarela (Tringa melanoleuca) (Naka y Rodrigues, 2000). En cuanto a los mamíferos, hay ejemplos, como el gambá (Didelphis aurita), la nutria neotropical (Lontra longicaudis), el ratão do banhado (Myocastor coypus) y la cuíca (Lutreolina crassicaudata), que se encuentran tanto en los manglares como en la vegetación de su entorno próximo (Graipel et al., 2001).

Sin embargo, muchas de estas especies están amenazadas de extinción, como el caso de la nutria neotropical (Lontra longicaudis) (IBAMA, 1989; Rheingantz y Trinca, 2015). Este hecho viene ocurriendo debido la ocupación humana, ocasionando la disminución y aislamiento de los manglares entre sí y con la vegetación de su entorno próximo, impidiendo que las especies nativas se trasladen entre sus hábitats. Estas circunstancias determinan la importancia de la conectividad ecológica como uno de los objetivos principales para la defensa del medio ambiente y la conservación de los servicios ecosistémicos de los manglares.

\subsection{FACTORES HUMANOS}

Este subcapítulo hace un análisis sobre la ocupación humana a lo largo de la historia en la Región Metropolitana de Florianópolis. A través del desarrollo del uso del suelo en el territorio, será demostrado la transformación del paisaje y las principales degradaciones ambientales producidas, como un factor que afectan directamente e indirectamente el ecosistema de los manglares.

En las secciones siguientes, serán abordados los temas sobre la formación política, territorial y poblacional de la Región Metropolitana de Florianópolis, el histórico de la ocupación del suelo y sus impactos ambientales.

\subsubsection{Región Metropolitana de Florianópolis}

El crecimiento urbano brasileño y la aglomeración de varias ciudades alrededor de una ciudad núcleo han causado muchos problemas de infraestructura urbana y uso del suelo. Así, surgió 
el concepto de región metropolitana en Brasil, que sirve como alternativa para integrar la organización, la planificación y la ejecución de las funciones públicas de interés común a los

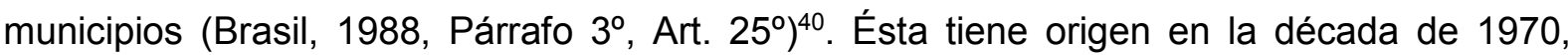
cuando hubo un crecimiento acelerado de las ciudades brasileñas, en gran parte a través de la migración, por los procesos de la industrialización en la cual estaba pasando el país. En la actualidad cuenta con un total de 38 regiones metropolitanas en todo el territorio nacional.

La Región Metropolitana de Florianópolis, siguiendo a una tendencia de las regiones metropolitanas de Brasil, está establecida por la Ley Complementaria de 1994, donde "se considera región metropolitana la agrupación de municipios limítrofes, exigiendo una planificación integrada y acción conjunta, con la unión permanente de esfuerzos para la aplicación de las funciones públicas de interés común de las entidades públicas activas" (Santa Catarina, 1994, Art. $\left.6^{\circ}\right)^{41}$.

Esta ley define las prestaciones de servicios públicos como función pública en los aspectos de salud y educación, transporte público, seguridad pública, sanidad pública, abastecimiento de agua, alcantarillado y suministro de alimentos. También cuenta con el ejercicio del poder de la policía administrativa para la preservación del medio ambiente, el control del uso y ocupación de la tierra y la conservación del patrimonio histórico y cultural (Santa Catarina, 1994, Art. $\left.3^{\circ}\right)^{42}$.

Sin embargo, la Ley de 1994 se formalizó solamente en el año de $1998^{43}$. Después fue abolida en $2007^{44}$ debido a cuestiones esencialmente políticas y se reconstituyó de nuevo en $2010^{45}$. Actualmente, según los datos del Instituto Brasileiro de Geografia e Estatística (IBGE, 2014), ocupa la posición 24 en cantidad poblacional de las regiones metropolitanas de Brasil, la posición cuarta de las del Sur de Brasil con un 0,55\% de la población total de Brasil, siendo São Paulo considerada la más poblada (10,32\% de la población total de Brasil).

En cuanto a la formación espacial y poblacional, la Región Metropolitana de Florianópolis está

\footnotetext{
${ }^{40}$ Brasil (1988). Constituição da República Federativa do Brasil, Brasília, Senado Federal.

41 Santa Catarina (1994). Lei Complementar n 104. Dispõe sobre os princípios da regionalização do Estado e adota outras providências.

42 Ídem.

43 Santa Catarina (1998). Lei Complementar $n^{\circ}$ 162. Institui as Regiões Metropolitanas de Florianópolis, do Vale do Itajaí e do Norte/Nordeste Catarinense e estabelece outras providências.

${ }^{44}$ Santa Catarina (2007). Lei Complementar $n^{\circ} 381$. Dispõe sobre o modelo de gestão e a estrutura organizacional da administração pública Estadual.

45 Santa Catarina (2010). Lei Complementar $n^{\circ}$ 495. Institui as Regiões Metropolitanas de Florianópolis, do Vale do Itajaí, do Norte/Nordeste Catarinense, de Lages, da Foz do Rio Itajaí, Carbonífera e de Tubarão.
} 
ubicada en la parte Este del Estado de Santa Catarina. Se constituye a partir del núcleo metropolitano conurbado del Municipio de Florianópolis, que es la Capital Estatal de Santa Catarina, y además, cuenta con un área de expansión. El núcleo metropolitano está formado por nueve municipios, que son: São José, Palhoça, Biguaçu, Santo Amaro da Imperatriz, Governador Celso Ramos, Águas Mornas, Antônio Carlos y São Pedro de Alcântara. El área de expansión se compone de 13 municipios interconectados, sumando un total de 22 municipios. Sin embargo, para este estudio será solamente abordado el núcleo metropolitano como el área de interés de la Región Metropolitana de Florianópolis (Figura 6.26, Tabla 6.3 y Figura 6.27).

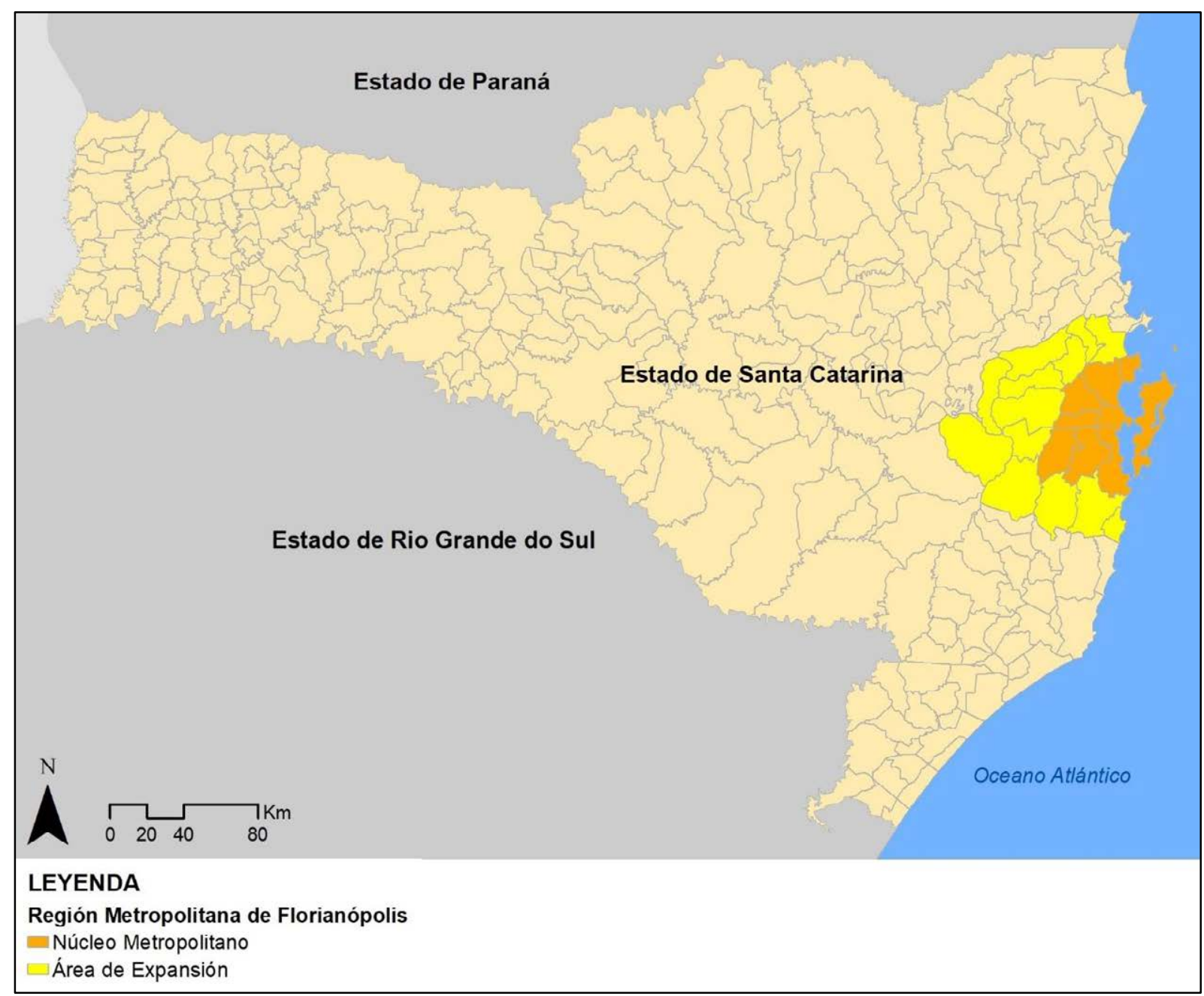

Figura 6.26: Región Metropolitana de Florianópolis. Fuente: Elaboración propia. 


\begin{tabular}{|c|c|c|c|}
\hline \multirow{2}{*}{ Municipios } & Áreas & Población & Densidad poblacional \\
\hline & $\mathrm{Km}^{2}$ & Año 2017 & $\mathrm{Hab} / \mathrm{Km}^{2}$ \\
\hline Florianópolis & 675,41 & 485.838 & 623,68 \\
\hline São José & 150,45 & 239.718 & $1.376,78$ \\
\hline Palhoça & 395,13 & 164.926 & 347,56 \\
\hline Biguaçu & 367,89 & 66.558 & 156,94 \\
\hline Santo Amaro da Imperatriz & 344,05 & 22.609 & 57,62 \\
\hline Governador Celso Ramos & 117,19 & 14.229 & 110,93 \\
\hline Antônio Carlos & 233,57 & 8.327 & 32,62 \\
\hline Águas Mornas & 327,36 & 6.298 & 16,95 \\
\hline São Pedro de Alcântara & 140,02 & 5.602 & 33,6 \\
\hline Total & $2.751,07$ & 1.014.105 & 368,62 \\
\hline
\end{tabular}

Tabla 6.3: Región Metropolitana de Florianópolis (Núcleo Metropolitano). Fuente: IBGE ${ }^{46}$.

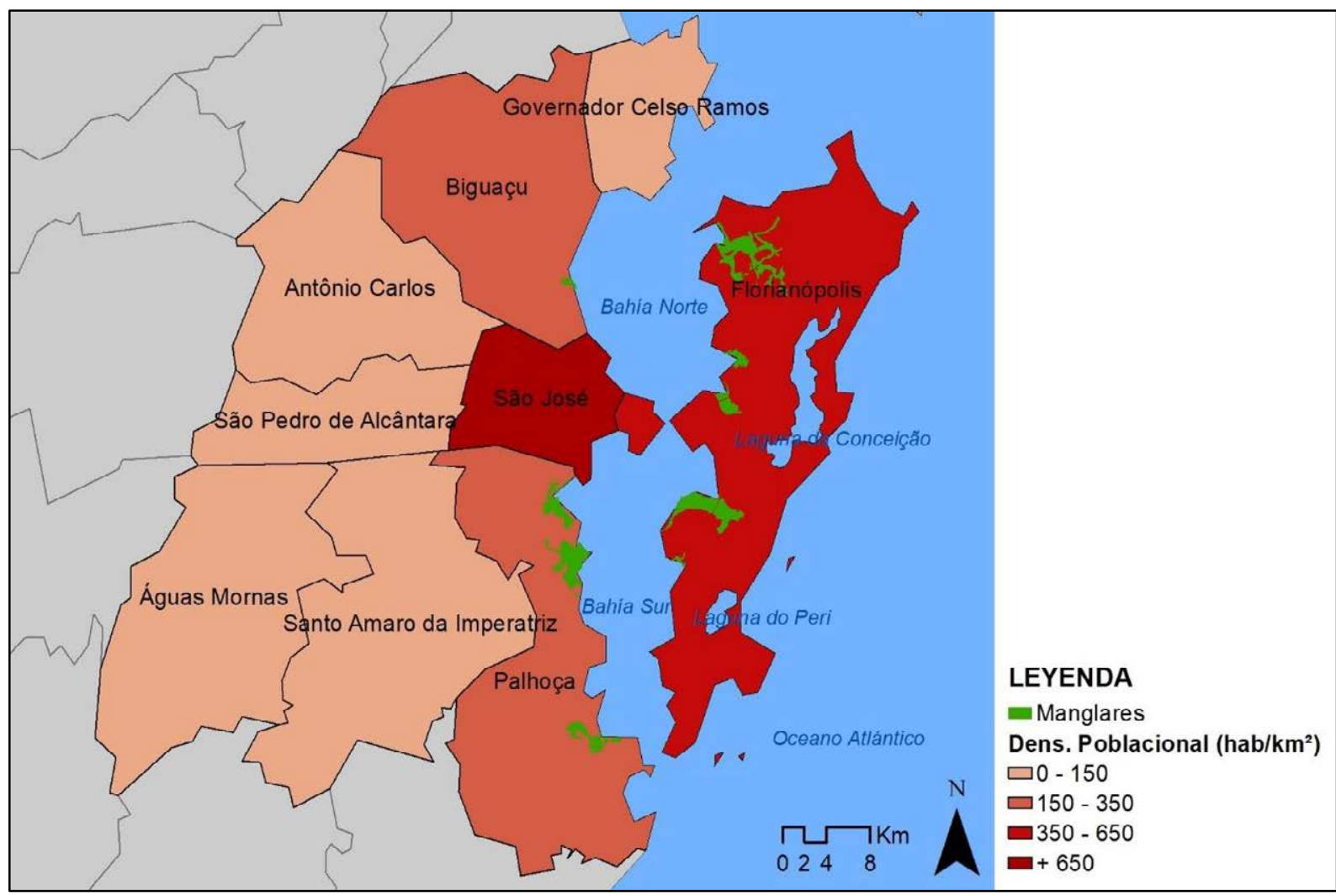

Figura 6.27: Densidad de la Región Metropolitana de Florianópolis. Fuente: Elaboración propia con los datos de IBGE ${ }^{47}$.

Durante su desarrollo histórico (entre los siglos XIX y XX), la configuración espacial sufrió

46 IBGE, Instituto Brasileiro de Geografia e Estatística. Disponible en http://www.cidades.ibge.gov.br/ (fecha de consulta: noviembre de 2017).

47 Ídem. 
muchos cambios que se sucedieron de la siguiente forma: a partir del Municipio de Florianópolis, se originaron los Municipios de Biguaçu y São José (1833); de São José, Palhoça (1894); de Palhoça, Santo Amaro da Imperatriz (1961); de Santo Amaro da Imperatriz, Águas Mornas (1961); de Biguaçu, Antônio Carlos (1963) y Governador Celso Ramos (1963) (Cabral, 1970, Anexo 3). El Municipio de São Pedro de Alcântara fue fundado sólo más tarde, en 1995, a partir del Municipio de São José.

En la actualidad, el Municipio de Florianópolis es considerado el polo integrador del resto de los municipios, con el mayor número de población, seguido de São José, Palhoça y Biguaçu, por tener proximidad física con Florianópolis. Estos cuatro municipios representan cerca del 94\% de la población y del 92\% de la densidad poblacional de la Región Metropolitana (dentro del núcleo metropolitano). En la mayoría de estos municipios conurbados se encuentran los manglares de estudio, con la excepción del Municipio de São José, siendo esta situación una amenaza para estos frágiles ecosistemas.

\subsubsection{Histórico del uso del suelo}

Los municipios de la Región Metropolitana de Florianópolis tienen en común los procesos de ocupación humana a lo largo de la historia, que se pueden dividir en tres partes: periodo precolonial, primer período y segundo período (Figura 6.28). El período pre-colonial trata de los primeros habitantes en la Región Metropolitana, antes del descubrimiento y colonización de Brasil por los lusitanos (antes del siglo XVI). El primer período está marcado por la ocupación agrícola del suelo con la llegada de inmigrantes, principalmente los portugueses de las islas de Azores, en los mediados del siglo XVIII, durante el periodo colonial. Por fin, en el segundo período se da el desarrollo urbano a partir de mediados del siglo XX.

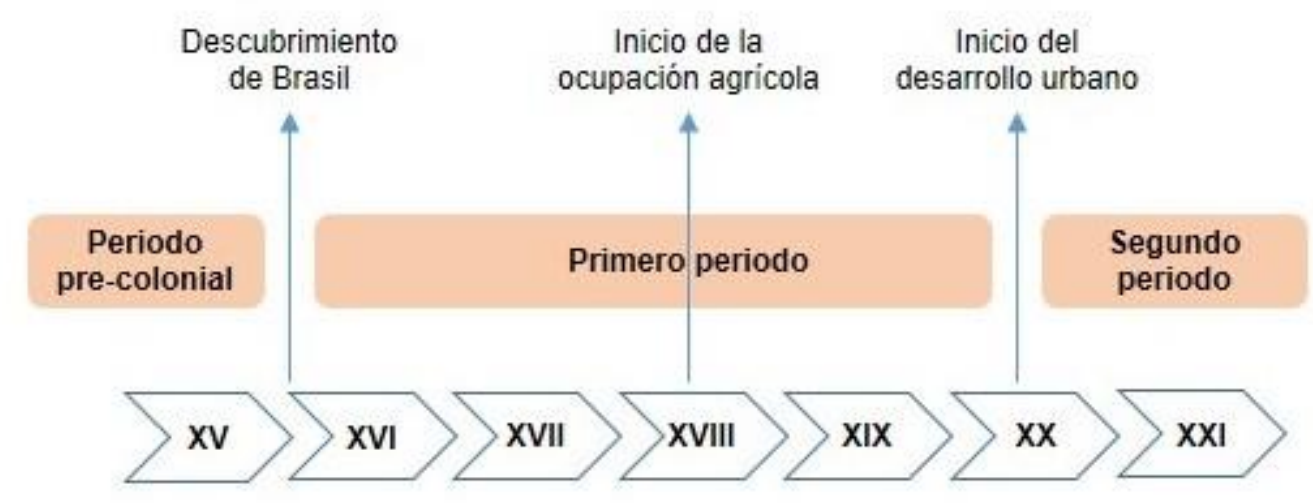

Figura 6.28: Línea del tiempo de la ocupación del suelo. Fuente: Elaboración propia. 


\subsubsection{Período pre-colonial}

Se verifican al menos tres tipos distintos de asentamientos humanos hasta el comienzo del período colonial (siglo $\mathrm{XVI}$ ), que son: los cazadores-recolectores, los pescadores precoloniales Jê (Itararés) y los agricultores de tradición Guaraní (Carijós) (IBAMA, 2003; Fossari, 2004; CECCA, 1996).

Los cazadores-recolectores vivieron hace unos 4.500 años y dejaron testigos arqueológicos en forma de sambaquís (Fossari, 2004, p. 81). Por la denominación en sí, eran cazadores y recolectores de moluscos, a pesar de que, entre ellos, la pesca también era común, según afirma la misma autora.

Los pescadores pre-coloniales Jê (también conocidos como Itararés) desarrollaron una intensa actividad pesquera, lo que permite caracterizarlos como una población de pescadores. Pero también se dedicaban a la caza de aves y mamíferos, y a la recolecta de moluscos y crustáceos; sin embargo, en menor cantidad que los cazadores-recolectores (Fossari, 2004, p. 84). De acuerdo con IBAMA (2003, p. 58, cap. 4), se estima que la ocupación por parte de este grupo ocurrió alrededor del siglo $X$.

Tanto los cazadores-recolectores como los pescadores pre-coloniales Jê, probablemente hicieron uso de los manglares por albergar muchas especies de peces, moluscos y crustáceos, constituyendo como una rica fuente de recursos alimenticios para las poblaciones humanas. Según Fossari (2004, p. 180), aunque no se puede caracterizar la población de los pescadores pre-coloniales Jê como de ambientes estrictamente marinos, tendrían exploradas intensamente las zonas de manglares.

La tercera y última población pertenecía a los agricultores de tradición Guaraní, del asentamiento de Carijós ${ }^{48}$, que practicaban la agricultura como medio de subsistencia durante el siglo XIV (IBAMA, 2003, p. 58, cap. 4). Sin embargo, su alimentación estaba asociada también a los productos de la caza y de la pesca (Cabral, 1970, p. 32). Fueron los primeros a producir una densidad poblacional y cada pueblo tenía entre 30 y 80 viviendas en la parte insular del territorio (CECCA, 1996, p.33).

Conforme los registros arqueológicos, se verificaron que estas ocupaciones eran de pequeña escala y no tuvieron efectos relevantes sobre el medio ambiente. Las descripciones de los navegadores revelaron una naturaleza casi sin cambios antes del siglo XIX, como se muestra

\footnotetext{
48 Denominación dada al poblado de Guaranís en la costa Sur de Brasil.
} 
en la carta del navegador inglés George Shelvocke, de 1719 a través de la siguiente cita:

La isla está toda cubierta de bosques inaccesibles, por lo que, con la excepción de las plantaciones, no hay un suelo hueco en toda ella. La más pequeña de las islas alrededor también abunda en una amplia variedad de árboles y arbustos llenos de espinas, lo que las veda totalmente su acceso. En cuanto al continente de Brasil, en este lugar, puede ser, con justicia, llamado de un amplio y continuo bosque (Haro, 1979, p. 46).

La vegetación es también relatada a través de la carta del navegador inglés George Anson en 1740, cuando estuvo en la isla:

Está cubierta de una selva de árboles siempre verdes, que, por la fertilidad del suelo, se entremezclan con zarzas, espinos y arbustos, que su totalidad forma un conjunto imposible de avanzar, a no ser que se tome un camino que los habitantes hicieron para su comodidad. Estos caminos y algunas tierras ubicadas a lo largo del margen continental, que desbravamos para hacer siembra de cultivo, son los únicos lugares en la isla que no están cubiertos de árboles. Los bosques proporcionan en esta isla un perfume admirable, por la gran cantidad de árboles y arbustos aromáticos que allá se encuentran (Haro, 1979, p. 67).

A partir del siglo XVI, con el descubrimiento de Brasil y el comienzo del periodo colonial, la población de Guaranís se contactó con los primeros navegantes y, por el dominio territorial, muchos desaparecieron. Los motivos fueron el trabajo esclavo o enfermedades desconocidas traídas por los navegantes (Santos, 1977, p. 31 y 32). Después de este primer contacto, empezaron a surgir nuevas formas de ocupaciones en el territorio, más intensas, significativas y también destructivas para el medio ambiente.

\subsubsection{Primer periodo: ocupación agrícola}

Poco después del descubrimiento de Brasil y establecido como una colonia portuguesa, la costa de la Región Metropolitana de Florianópolis comenzó a ser muy visitada por navegantes y piratas, principalmente españoles. Representaba un punto de parada para los viajeros que recorrían la ruta marítima hacia la cuenca del Río del Plata (entre Uruguay y Argentina). Según Souza Sobrinho (1972, p. 3), por su privilegiada situación geográfica y también por la seguridad de que sus bahías ofrecían, fue muy utilizada para el restablecimiento de agua, alimentos y madera para el mantenimiento de las embarcaciones que allí paraban.

De acuerdo con el navegador inglés George Anson (1740), se consideraba que esta localidad era donde se encontraba el mejor refugio de toda la costa brasileña (Haro, 1979, p. 63). El navegador describe que "todo lo que esta isla se parece de interesante a nosotros, es que 
nos puede ofrecer un lugar donde alojarse y refrescarse, para nuestros navíos que deseen seguir al mar del Sur" (Haro, 1979, p. 68). En la siguiente ilustración (Figura 6.29) se demuestra el dibujo con navíos entrando a través de la Bahía Norte (entre la isla y el continente), obra del navegador George Anson.
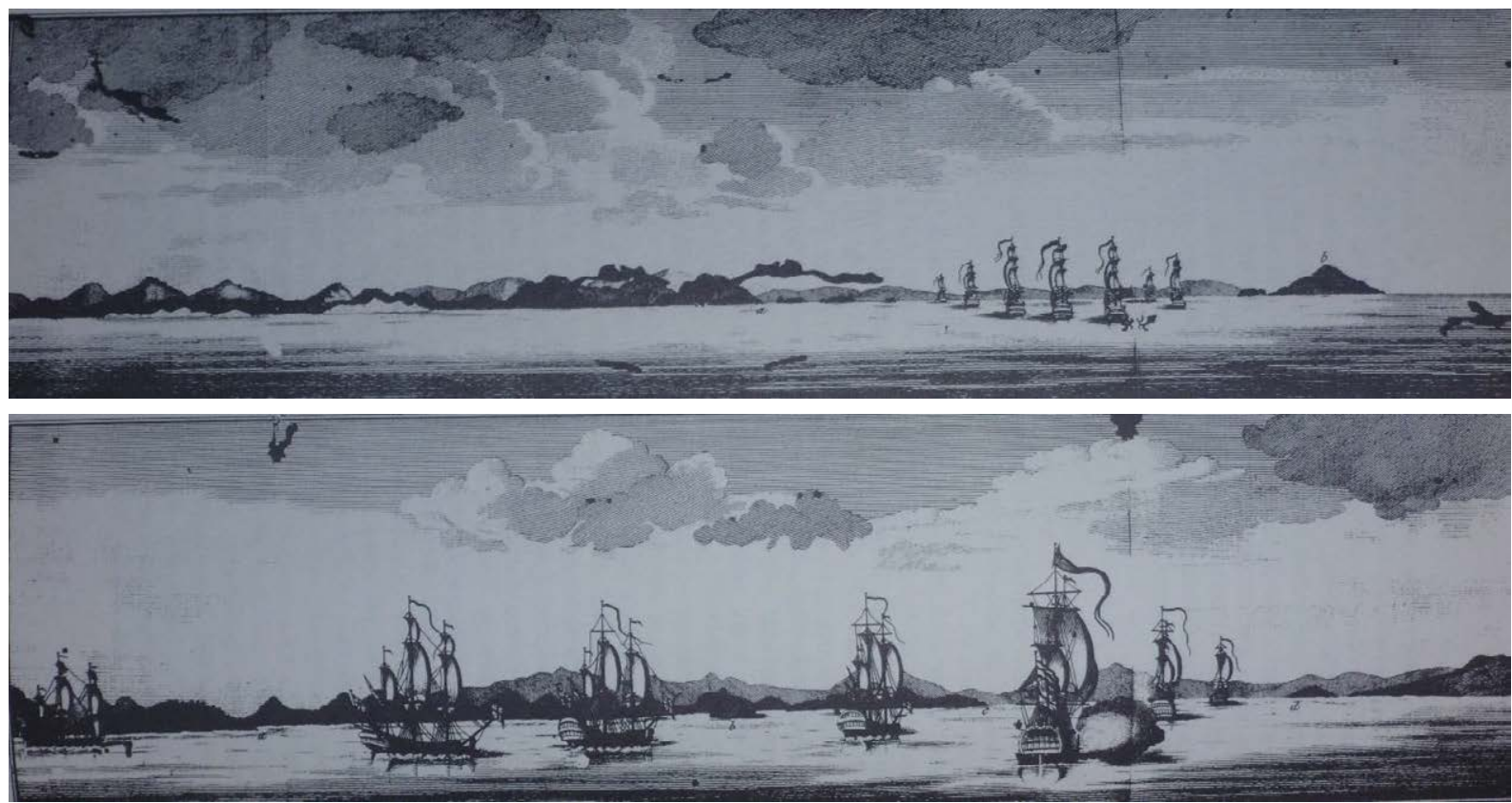

Figura 6.29: Navíos en la Bahía Norte. Fuente: George Anson (1740) (Haro, 1979, p. 68).

En el año de $1673^{49}$, por iniciativa portuguesa, se estableció una pequeña ocupación en la isla al fundar Francisco Dias Velho el pueblo de Nossa Senhora do Desterro (actual Municipio de Florianópolis) ${ }^{50}$. En esta época, residían poco más de 100 habitantes, con edificaciones compuestas por factorías, una capilla y algunas viviendas, además de una pequeña área agrícola y ganadera (IBAMA, 2003, p. 58, cap. 4).

Solamente a partir de mediados del siglo XVIII empezó un cambio notable en el paisaje local con el establecimiento de una inmigración portuguesa para la protección contra las invasiones españolas. Este hecho se verificó a través de los relatos de viajantes, con fecha principalmente a partir de los años de 1800, según afirma Caruso (1983, p. 46 y 47). Los inmigrantes procedían principalmente de las Islas de Azores, pero también de la Isla de Madeira, y se alcanzó un total de cerca de 6.000 inmigrantes entre 1748 a 1756 (CECCA,

\footnotetext{
49 En el año de 1673 se celebra la fundación del Municipio de Florianópolis.

50 Desde 1894, Desterro pasó a llamarse de Florianópolis con la Proclamación de la República de Brasil (1889), en homenaje al según presidente de Brasil, el militar Floriano Peixoto.
} 
1996, p. 45), además de la población de africanos que fueron esclavizados.

La población de inmigrantes se ubicó en el lado Oeste de la isla y también en la costa del continente (Várzea, 1984, p. 13), formando núcleos poblacionales. A través de las Bahías Norte y Sur, Florianópolis se conectaba con los municipios de Biguaçu, São José y Palhoça, con pequeñas embarcaciones para el transporte de personas y mercancías. De este modo, se desarrolló inicialmente el Municipio de Florianópolis y los municipios de la costa continental, estableciéndose en las cuencas hidrográficas y ocupando progresivamente las zonas continentales fértiles del altiplano. En la Figura 6.30 se muestran los principales núcleos poblacionales que se fueron estableciendo en la isla y el continente, y los caminos marinos y terrestres entre los núcleos y fuertes. Se verifica que la ubicación de los caminos terrestres en la isla durante este período se mantienen hasta la actualidad.

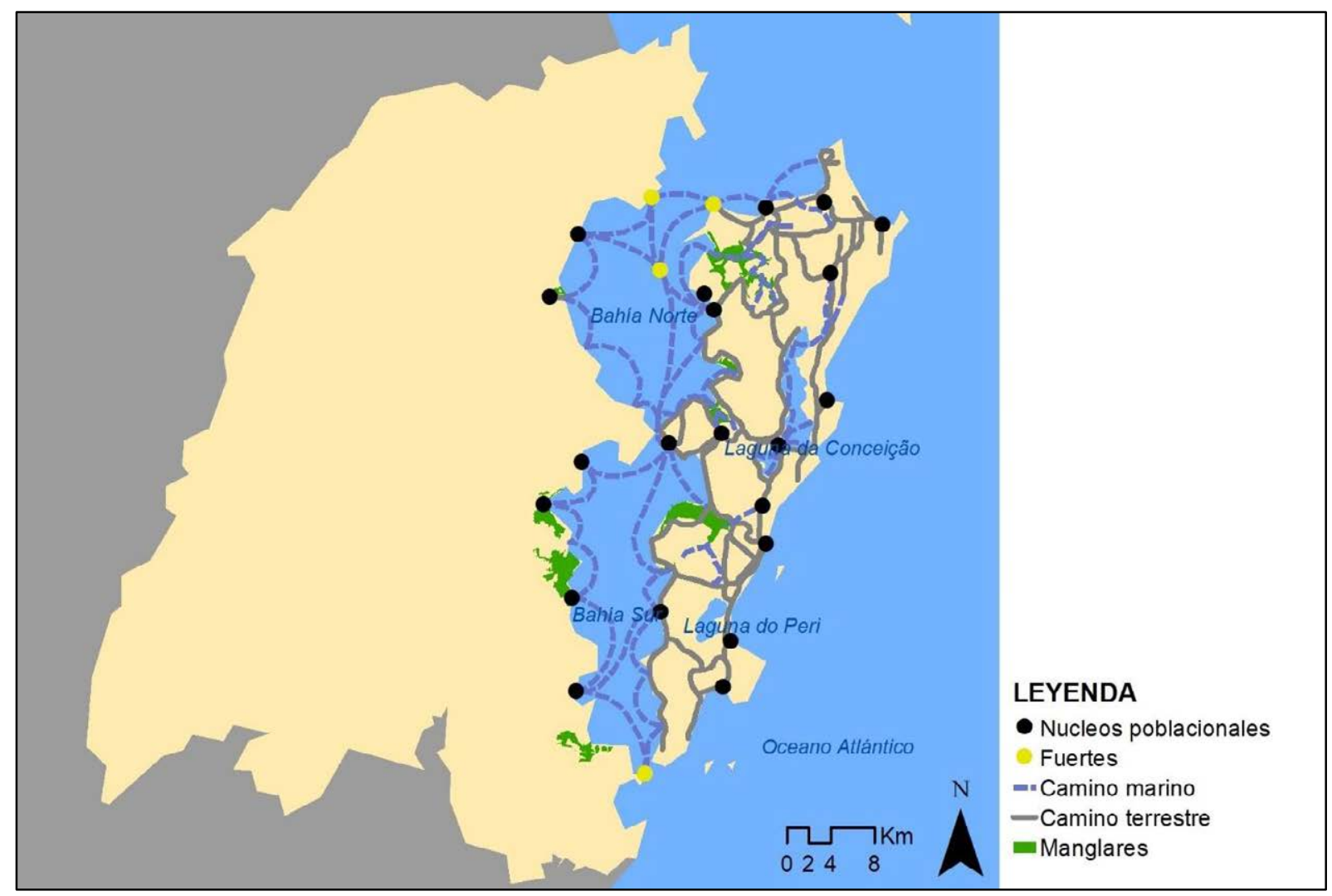

Figura 6.30: Núcleos poblacionales. Fuente: Elaboración propia con los datos de Reis (2010).

Como consecuencia, se asentó una economía basada principalmente en la agricultura, además de la pesca y el comercio, fortaleciendo algunos puntos de aglomeración poblacional. De acuerdo con Veiga (1993, p. 27 y 28), la planificación territorial establecida se caracterizó por la implantación de edificaciones típicamente lineales, siguiendo la línea de la playa, abajo de la altitud de 10 metros. Se puede observar en la Figura 6.31 el dibujo de una pequeña 
urbanización en el inicio del siglo XIX, en la parte insular central.

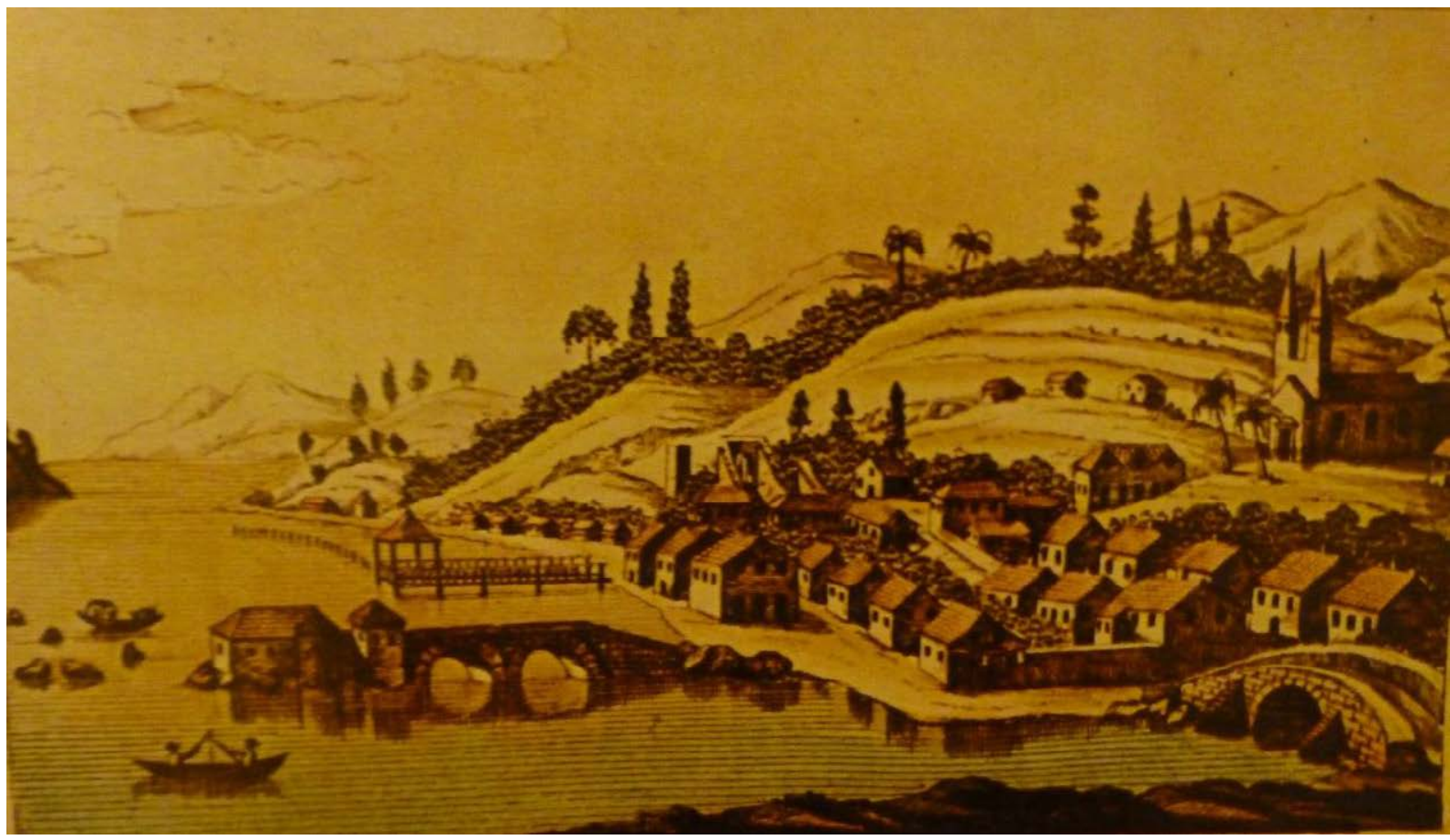

Figura 6.31: Planificación territorial. Fuente: Adam Johann von Krusentern, navegador ruso (1803) (Haro, 1993, p. 147).

Según Souza Sobrinho (1972, p. 9), a pesar de los métodos primitivos utilizados, la agricultura se desarrolló en gran medida gracias a la tierra fértil y la bondad del clima. Sin embargo, de acuerdo con Caruso (1983, p. 87), la fertilidad de la tierra se consideraba baja, pero con las vastas áreas disponibles no se preocupaban en abonar los suelos. Así, el cultivo de la agricultura fue realizado a través de incendios controlados del terreno, destruyendo toda la cubierta vegetal, en un proceso de abandono y ocupación de nuevas áreas de manera continua (Caruso, 1983, p. 88). En este momento, la práctica agrícola principal era la harina de mandioca, además de azúcar, trigo y arroz, entre otros.

La devastación "ocurrió inicialmente en la zona costera, en las llanuras cuaternarias, y cuando el suelo se agotaba, la frontera agrícola se movía hacia el interior, subiendo las laderas de colinas hasta llegar en las cimas." (Caruso 1983, p. 100). Este hecho es destacado por el botánico francés Saint-Hilaire en su visita al Sur de Brasil, en 1820:

(...) todas las tierras que circundan la Ciudad de Santa Catarina fueron deforestadas y sólo se pueden ver bosques en la parte superior de las colinas; creo que puedo decir, sin embargo, que al menos en esta parte de la isla, una décima parte de la tierra llega a ser cultivada. Por cultivar siempre en el mismo terreno, sin nunca fertilizar, los agricultores cansaron la tierra, y por toda la parte se encuentran capoieras muy raquíticas (Saint-Hilaire, 1978, p. 176 y 
177).

El mismo autor señala que, por la falta de tierra disponible para la agricultura en la isla, van a buscar en la parte continental (Saint-Hilaire, 1978, p. 177). Por esta razón, la deforestación fue aplicada en grandes cantidades, no sólo en la isla, sino también en el continente, donde no hay una limitación estricta de la tierra por el mar como ocurre en la isla.

Así, el proceso histórico del uso del territorio llevó a la pérdida de gran parte de la vegetación original, donde la agricultura fue considerada la principal causa de la degradación ambiental. Sin embargo, es importante evidenciar que la devastación también tenía como objetivo la obtención de leña para la construcción naval, civil, móviles y exportación; para la obtención de energía para el uso doméstico, molinos, talleres de cerámica, curtidurías, hornos y exportación; además del espacio para la ocupación urbana, aunque en pequeñas áreas (Caruso, 1983, p. 97 y 98). En cuanto a la ganadería, ocupaban pequeños espacios. Según Várzea (1984, p. 117), la ganadería (utilizada para el consumo y servicios en la agricultura) ocupaba, en general, los terrenos accidentados en las laderas de las colinas.

En los manglares, la deforestación fue dirigida principalmente para obtener tinta, por tener especies productoras de tanino, utilizado en la confección de cueros y dar resistencia a las redes de pesca, hechas de fibra de algodón (Caruso, 1983 p. 90). También fueron utilizados como combustible para hornos, según relata Várzea (1984, p. 124) y molinos de harina y aguardiente (Souza Sobrinho, 1972, p. 7). De acuerdo con Caruso (1983, p. 91), la estructura vegetal de manglar, por su tamaño mediano, era fácil de ser cortada, además de fácil de ser transportada por embarcaciones, al estar en las márgenes de los ríos y cerca de la costa.

Existe constancia de que la superficie de los manglares disminuyó para dar paso a la agricultura y ganadería. Aunque, proporcionalmente, los manglares fueron eliminados en menor cantidad en comparación con la Selva Pluvial Tropical. Según Trindade (2009, p. 113), posiblemente por la dificultad técnica para convertirlos en tierra habitable y cultivable, y por la disponibilidad de otras zonas más favorables para los fines buscados. La misma autora señala que las zonas más alteradas eran sus bordes y las orillas de los ríos, por la facilidad del acceso. Con la gran degradación ambiental, los manglares, durante este periodo, eran la formación dominante en el paisaje de la isla (Trindade, 2009, p. 112).

De esta manera, conforme Caruso (1983, p. 84), la llegada de los inmigrantes portugueses inició la "verdadera y definitiva ocupación de la isla" y "que en menos de 200 años se deforestó casi por completo sus bosques." La deforestación se produjo tanto en la isla, cuanto en la 
parte continental. Pero, solamente en la isla, se estima una pérdida de más del $76 \%$ de la vegetación original (Caruso, 1983, p. 145).

Durante el siglo XIX, además de la agricultura, la obtención de leña y la ganadería intensificaron las actividades comerciales y portuarias, estimuladas por los inmigrantes de diversos orígenes, llegados, en gran parte, tras la Independencia de Brasil (1822). Los inmigrantes eran de orígenes alemanes, italianos, libaneses, sirios y griegos. Se estableciendo no solamente en el área de la Región Metropolitana, sino como en la totalidad del Estado. En el año de 1844, la provincia de Santa Catarina (actual Estado de Santa Catarina) contaba con 72.814 habitantes, de los que 14.382 eran esclavos (Cabral, 1970, p. 141). Además de los impactos ambientales producidos por la deforestación en este periodo, era también común echar la basura y los desechos en las playas y en los manglares (IBAMA, 2003, p. 59, cap. 4).

En el siglo XX, con el empobrecimiento de los suelos causado por las prácticas agrícolas y la disminución de dicha actividad, se inició el proceso de regeneración natural en áreas previamente cultivadas. Motivado por la escasez de los recursos naturales, se recurrió a la plantación de vegetación exótica para la recuperación forestal y fines productivos. Este hecho fue incentivado por una política nacional que se inició más tarde, a partir del mediado del siglo $\mathrm{XX}$, y destaca en el territorio la vegetación de pinos y eucaliptos. La siembra de pinos se realizó principalmente en las áreas de vegetación de restinga, ya que estaban consideradas como áreas improductivas por su característica ecosistémica poco desarrollada.

\subsubsection{Segundo periodo: densificación urbana}

A partir de la segunda mitad del siglo XX hubo cambios debido al crecimiento económico y demográfico. Este fenómeno de la urbanización se manifestó entre las décadas de 1950 y 1960 , en consonancia con la intensificación del movimiento del campo hacia la ciudad en todo el mundo (Peluso Junior, 1991, p. 32). Sin embargo, el movimiento fue reforzado por la baja productividad agrícola, resultante del sistema de rotación de la tierra, lo que obligó al agricultor a su abandono (Peluso Junior, 1991, p. 33).

De esta forma, surgió el primer Plan Director de Florianópolis en 1955 (Ley n 246/55) ${ }^{51}$, que proponía elaborar soluciones urbanas para eliminar el atraso de la ciudad a través de la industrialización. A diferencia de la realidad de otras capitales brasileñas, Florianópolis tenía

\footnotetext{
51 Florianópolis (1955). Lei n² 246, de 15 de novembro de 1955. Aprova o código municipal.
} 
un débil potencial económico y financiero, marcado por la ausencia de industria, baja densidad poblacional y dispersión del conjunto urbano. El plan se limitó en la parte central y en el continente del Municipio, pero no consideró el interior de la isla.

El crecimiento urbano se estructuró de acuerdo con las características heredadas de la colonización azoriana, a través de procesos de ocupación diferenciadas. Según Reis (2010), en la zona donde se produjo la agricultura con subdivisiones rurales, la transformación urbana fue espontánea, caracterizada por pequeños loteos, con trazados en espiga de pez (calles estrechas, largas y sin conexiones con otras calles paralelas). En cuanto a los suelos no subdivididos, de uso comunal, surgieron los grandes loteos, con trazados más regulares (Reis, 2010).

Entre las décadas de 1960 y 1970, el Municipio de Florianópolis conformó una economía orientada al servicio público y el comercio, se fortaleció como Capital del Estado de Santa Catarina. Con el crecimiento del sector público, Florianópolis comenzó a albergar nuevos profesionales de otras localidades del país, atraídos por las instituciones federales y estatales que se instalaron ahí, como las universidades y la estatal de energía, que se encuentran en la cuenca de Itacorubi (vector de la expansión urbana de Florianópolis), aumentando la urbanización en esta área y con una inmigración poblacional con rentas más altas.

En la década de 1970, con el fin de satisfacer las demandas de crecimiento de las ciudades, se realizaron grandes obras de carreteras a través de recursos federales y estaduales. Con la construcción de las carreteras federales BR - 101 (que sigue del Norte al Sur por casi toda la costa brasileña) y BR - 282 (que conecta Florianópolis hacia el interior), el sistema viario pasó a desarrollarse rápidamente. Las principales industrias se instalaron en sus márgenes, facilitando la exportación y sustituyendo los transportes marítimos por las carreteras.

En consecuencia, el Municipio de São José se ha desarrollado a lo largo de la BR - 101, con propagación en las dos direcciones (Norte y Sur), lo que contribuye al desarrollo socioeconómico y la expansión urbana en los Municipios de Palhoça y Biguaçu. Según Peluso Junior (1991, p. 320), en este momento, el Municipio de Florianópolis perdió el carácter de ciudad aislada y se ha transformado y constituido en un territorio de edificaciones difusas junto a las ciudades próximas. A partir de la implantación de la carretera estatal SC - 401, que une la zona central y Norte de la isla, Florianópolis comenzó a urbanizarse más intensamente en la parte Norte. Solamente en la década de 1980 surgieron carreteras que conectan la parte Sur y Este de la isla, ampliando las áreas del sector turístico, además de la expansión inmobiliaria, con una ocupación de carácter denso y vertical. 
Tras el proceso de conurbación de los Municipios, surgió la necesidad de la implantación de un plan adecuado para una unidad más grande (Peluso Junior, 1991, p. 321). A partir de este hecho, se estableció el según Plan Director en 1976 (Ley n 1440/76) ${ }^{52}$, con el objetivo de planificar la Región Metropolitana de Florianópolis, que estaba en el desarrollo de crecimiento urbano, convirtiendo Florianópolis en un gran centro urbano de importancia regional, capaz de equilibrarse con las demás capitales del Sur de Brasil: Curitiba al Norte y Porto Alegre al Sur. En secuencia metodológica, el Plan Director de Florianópolis debería esperar para que primero se planeara el área regional metropolitana, y después seguir con el ámbito municipal (Rizzo, 1993, p. 68).

El crecimiento poblacional de los municipios fue continuo, con mayor intensidad a partir de la década de 1990. Actualmente está considerada una de las regiones metropolitanas de Brasil que más aumentó su población en las últimas décadas, según el United Nations Regional Information Centre for Western Europe (UNRIC). En 1992 contaba con 546.844 habitantes y hoy se encuentra en unos 1.014.105 de habitantes, de acuerdo con los datos de IBGE $^{53}$, lo que supone un crecimiento total del $85,45 \%$.

La inmigración llegaba principalmente de las regiones Sur y Sudeste de Brasil. De acuerdo con CECCA (1996, p. 111 y 112), señala que no sólo la inmigración de clases sociales bajas fueron responsables por la ocupación en las zonas de preservación, también las clases medias y altas, desvalorando el ambiente y la calidad de vida. Según Bueno (2006, p. 135) y CECCA (1997, p. 26), los segmentos sociales de mayores rentas se han aprovechado de la permisividad de los planes en relación al patrimonio paisajístico y ecológico, sin la actuación de los órganos de fiscalización contra las ocupaciones ilegales. Sin embargo, Bueno (2006, p. 124 y 125) afirma que los problemas van además de la legalidad de los asentamientos, sino a través del punto de vista ambiental, como la falta de saneamiento y las redes de carreteras comprometidas por la falta de dimensionamiento y de pavimentación compatibles y trazado inadecuado de las vías urbanas.

La Región Metropolitana de Florianópolis se ha tornado uno de los principales polos de turismo de playa durante el verano y de industria de tecnología en Brasil, donde destaca el Municipio de Florianópolis. Los municipios adyacentes, principalmente São José, Biguaçu y Palhoça, tuvieron un gran crecimiento inicial por la proximidad espacial a Florianópolis. Durante un largo

\footnotetext{
52 Florianópolis (1976). Lei $n^{\circ} 1440$, de 31 de maio de 1976. Altera o Plano Diretor da cidade e dá outras providências.

53 IBGE, Instituto Brasileiro de Geografia e Estatística. Disponible en http://www.cidades.ibge.gov.br/ (fecha de consulta: noviembre de 2017).
} 
tiempo fueron considerados como ciudades dormitorio de Florianópolis, sin embargo, en los últimos años han tenido una economía fuerte, de referencia en el país.

Palhoça se ha convertido en un importante productor brasileño de mariscos y ostras, también destaca en el turismo de playa en el verano y el turismo ecológico. En los Municipios de São José y Biguaçu se han formado un gran centro industrial y también áreas importantes de servicios y comercios. Los otros municipios que conforman la Región Metropolitana (Santo Amaro da Imperatriz, Governador Celso Ramos, Aguas Mornas, Antônio Carlos y São Pedro de Alcântara) contienen un reducido tamaño poblacional y una economía más pequeña, pero se muestran como áreas importantes para la agricultura y el turismo.

Así, el gran crecimiento urbano de los últimos años se debe a la atracción turística y al crecimiento económico, generando oportunidades de empleo. Un punto a favor es también el potencial paisajístico, por la presencia de playas, dunas, manglares y las selvas, con grandes diversidades ecológicas. La Región Metropolitana también es conocida por tener una alta calidad de vida, siendo el Municipio de Florianópolis la capital brasileña con la mayor puntuación en el Índice de Desarrollo Humano (IDH), y la tercera ciudad de Brasil, calculado según el Programa de Desarrollo de las Naciones Unidas (PNUD) en $2010^{54}$.

Las propagandas nacionales e internacionales, a través de redes de comunicaciones, han estimulado la inmigración nacional e internacional, y son responsables del aumento poblacional en la Región Metropolitana, principalmente en el Municipio de Florianópolis. El periódico estadunidense The New York Times afirmó en 2009 que "Florianópolis es el destino del año"55. Newsweek consideró que el Municipio es una de las "diez ciudades más dinámicas del mundo", en $2006^{56}$.

A pesar de tener una gran belleza natural, el territorio presenta poca cantidad y calidad ambiental, como consecuencia de los años de intensa e inadecuada ocupación, con alteraciones paisajísticas y graves impactos ambientales. Según Reis (2010), el crecimiento urbano y acelerado de la población se desarrolla a través de una planificación que integra las acciones individuales en un proyecto colectivo, debido a la debilidad de los planes y las formas de control existentes, dando lugar a numerosos problemas urbanos y ambientales. De esta

\footnotetext{
54 PNUD, Programa de Desarrollo de las Naciones Unidas. Disponible en http://www.pnud.org.br/atlas/ranking/Ranking-IDHM-Municipios-2010.aspx (fecha de consulta: abril de 2015).

55 The New York Times. Disponible en http://www.nytimes.com/2009/01/11/travel/11party.html?_r=1\& (fecha de consulta: abril de 2015).

${ }^{56}$ Newsweek. Disponible en http://www.newsweek.com/id/46125/page/12 (fecha de consulta: abril de 2015).
} 
forma, la Región Metropolitana de Florianópolis, en su totalidad, establece una fuerte relación entre el crecimiento urbano y la necesidad de preservar el medio ambiente, necesitando de medidas siguiendo los criterios de sostenibilidad.

\subsubsection{Impactos ambientales}

El proceso histórico de desarrollo de la Región Metropolitana de Florianópolis originó variados impactos ambientales, como consecuencia de los largos años de degradación. Entre los cuales se pueden destacar la pérdida y la fragmentación de las áreas con vegetación autóctona; la plantación de especies exóticas; la inundación; la contaminación del agua, aire y suelo; y el cambio climático. Todos estos impactos están presentes en todo el territorio, dependiendo del uso del suelo para cada lugar.

En los ítems siguientes se identificará y evaluará cada impacto en particular, demostrando su incidencia directa e indirecta en el ecosistema de los manglares que, a su vez, perjudican la calidad de la vida de la población. A pesar de estar descritos de forma independiente, se deben analizar en su conjunto, pues un sólo factor está sujeto a diversos impactos que perturban al medio ambiente en varias escalas simultáneas, desde el nivel local hasta global.

\subsubsection{Pérdida y fragmentación de la vegetación}

La pérdida de la vegetación genera resultados preocupantes que perturban drásticamente la vida de los ecosistemas por la ausencia de hábitats. Con el agotamiento de la vegetación por la práctica agrícola en la Región Metropolitana de Florianópolis y tras su abandono en el siglo $X X$, se fue restableciendo la cobertura del suelo natural. Razón por la cual, actualmente, gran parte del territorio presenta vegetación secundaria en diferentes etapas de plantación (Capoeirinha, Capoeira y Capoeirão). Sin embargo, esta vegetación contiene bajo número de biodiversidad debido a su formación reciente (Sevegnani y Schroeder, 2013, p. 91).

Además de la pérdida, la fragmentación de la vegetación proporciona el aislamiento de las especies de la fauna y flora por la falta de la conectividad ecológica entre los hábitats, trayendo como consecuencia su riesgo de extinción. Según Sevegnani y Schroeder (2013, p. 206), la fragmentación también posibilita el aumento de la luminosidad, de la velocidad del viento y la reducción de la humedad en el interior de los bosques, volviéndose más vulnerables a la rotura de los árboles y la propagación de incendios, facilitando también la captura de los animales por los predadores. 
Los principales elementos antrópicos que han generado la pérdida y la fragmentación de los manglares entre sí y con la vegetación de su entorno próximo en el territorio son la agricultura, la ganadería, las edificaciones y las infraestructuras viarias. Aunque la perturbación causada por el área edificada está considerada más grave por imposibilitar la regeneración espontanea de la vegetación. La incidencia de estos elementos es muy clara en las áreas correspondientes a las llanuras de inundación, perjudicando directamente a los manglares.

A modo de ejemplo, la Figura 6.32 muestra la fragmentación del manglar de Itacorubi y del Río Tavares, en el Municipio de Florianópolis en dos partes, a causa de la ubicación de las infraestructuras viarias. Motivadas por la facilidad de accesibilidad a través de las vías, las zonas urbanas se han expandido, disminuyendo y aislando aún más las formaciones de estos manglares.
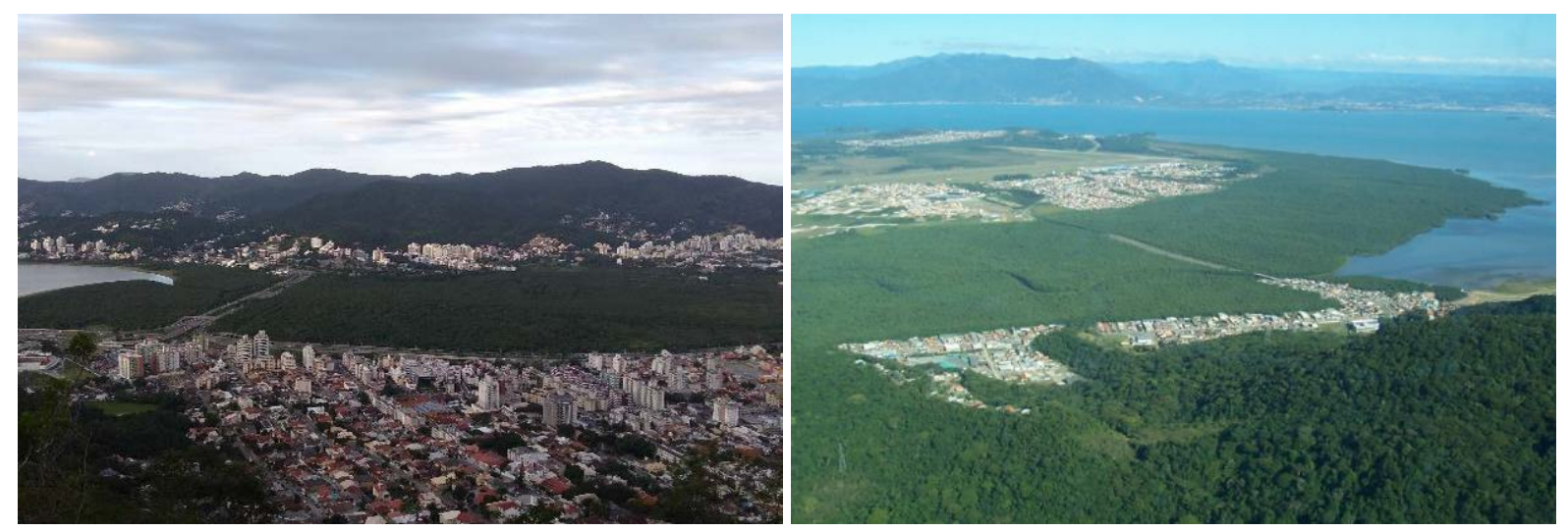

Figura 6.32: Perdida y fragmentación de los manglares. Fuente: Archivo de la autora (2017) e ICMBio, respectivamente.

\subsubsection{Plantación de especies exóticas}

Una de las principales consecuencias de la desaparición de especies de la fauna y flora nativa de una localidad es el establecimiento de plantas exóticas debido a la alteración del hábitat. Estudios demuestran que estas nuevas especies reducen la diversidad de especies locales y aumentan la producción de plantas de la comunidad invadida, provocando un impacto significativo a nivel de especie, comunidad y ecosistema (Vilà et al., 2011).

Hay muchos registros de especies exóticas, principalmente de pinos y eucaliptos en el territorio. Sin embargo, una de la más invasivas y perturbadoras es la especie Pinus elliottii. Esta especie de pinos procede de los Estados Unidos y está ubicada principalmente en las áreas de la costa Este de la parte insular (Municipio de Florianópolis), donde se ha eliminado gran parte de la vegetación de restinga que se encontraba en el lugar. Como la vegetación de restinga establece una comunicación directa con otros ecosistemas, la perturbación también 
perjudica a los manglares, pues afecta a especies animales que transitan entre los ecosistemas.

Según Santa Catarina (2016, p. 33), los pinos son extremamente dañinos para la biodiversidad local: sus semillas se dispersan con facilitad por el viento pudiendo alcanzar grandes distancias, crecen rápidamente excluyendo toda la vegetación nativa, consumen más agua reduciendo su disponibilidad en el medio y son poco exigentes en términos de fertilidad, llevando al empobrecimiento de los suelos.

Para suprimir esta situación, en 2012 se publicó la Ley $n^{\circ} 9.097^{57}$ en el Municipio de Florianópolis, que instituye la política de eliminación y sustitución de las especies de Pinus, Eucalyptus y Casuarina Spp. por especies nativas. La Ley también establece la prohibición de la siembra, la comercialización de plántulas y semillas, su posesión y el mantenimiento de plantas ya existentes. Esta ley confiere un plazo de diez años para la erradicación de estas especies en el municipio. Sin embargo, hasta el momento, la falta de infraestructura e inversión ha perjudicado el cumplimiento de la misma.

\subsubsection{Inundación}

La inundación es causada por la urbanización, en zonas a lo largo de los ríos o cerca del mar, principalmente donde se sitúan los manglares, influenciadas por los componentes naturales del ecosistema. Muchas de estas ocupaciones están situadas en áreas ilegales o se encuentran en zonas reglamentadas pero técnicamente cuestionables por estar sujetas a estos factores de impactos. Son provocadas por la ausencia de vegetación en estas localidades, sin estrategia de planificación, donde la población se ve directamente afectada. Los daños ocurridos en las calles y en las edificaciones en estos lugares son resultado de las Iluvias prolongadas, lluvias torrenciales o aumento excepcional de las mareas.

Los tipos de inundaciones por lluvias se pueden clasificar en dos modalidades: graduales o bruscas (Hermann, 2014). Las inundaciones graduales son consecuencias de las lluvias estacionales, lo que resulta en la crecida de los ríos por la precipitación durante los períodos prolongados y continuos. Según Hermann et al. (2014, p. 117), la frecuencia de este evento se asocia directamente con el fenómeno El Niño, de intensidad fuerte o moderada.

En la Figura 33, se encuentra la distribución espacial de los municipios de la Región

57 Florianópolis (2012). Lei Municipal n 9.097. Institui a política municipal de remoção e substituição de pinus, eucalyptus e casuarina spp por espécies nativas no município de Florianópolis e dá outras providências. 
Metropolitana más afectados por las inundaciones graduales. Los municipios que pertenecen a las clases de muy alta a alta, es decir, los más críticos, se ubican principalmente en las llanuras costeras y/o en las cuencas de los principales ríos. Según Hermann et al. (2014, p. 120), este tipo de desastre se debe a la intensa urbanización, el uso indiscriminado del suelo, la deforestación de la vegetación en los márgenes de los ríos, la insuficiente capacidad de las canalizaciones de drenaje y la ausencia de red pluvial, lo que reduce la capacidad de la infiltración de agua de lluvia, contribuyendo a un aumento de los periodos de inundaciones.

A diferencia de las inundaciones graduales, las inundaciones bruscas se originan por la aparición de lluvias que se producen de forma intensa y concentrada, con gran potencial destructivo. Se observa su ocurrencia muy alta en casi toda la Región Metropolitana de Florianópolis (Figura 6.33). Este evento está sucediendo principalmente a partir de 1990, con la intensificación del proceso de urbanización, y tienen, por lo general, mayor frecuencia en el periodo de verano, especialmente en los meses de enero y febrero, debido a las fuertes lluvias tropicales (Marcelino et al., 2014, p. 117).

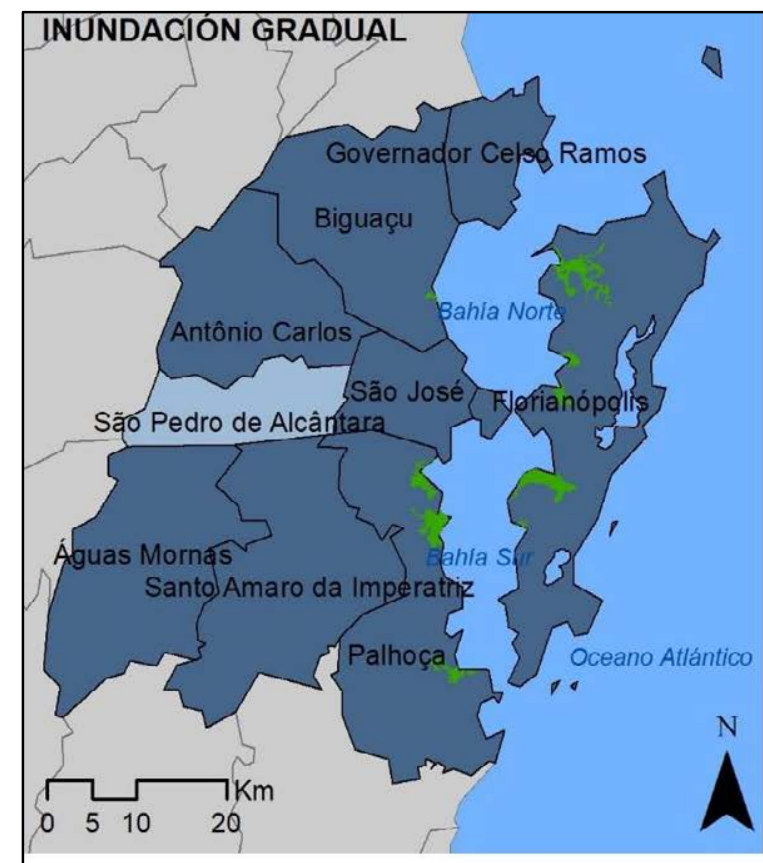

LEYENDA

Manglares

Frecuencia (1980-2010)

$\square$ Mediana (2-4)

$\square$ Muy Alta (8-16)

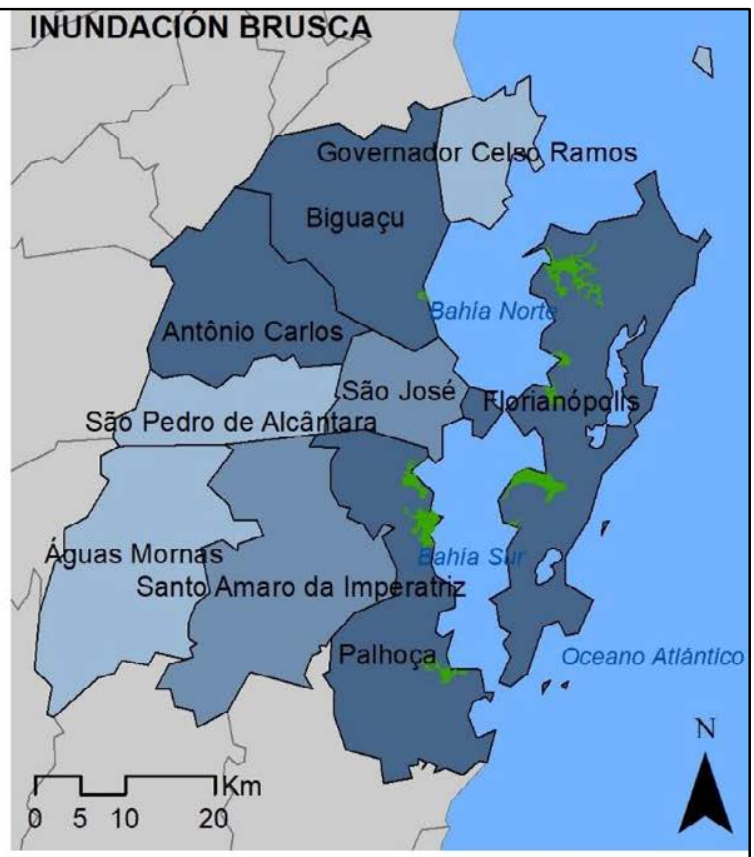

\section{LEYENDA}

Manglares

Frecuencia (1980-2010)

$\square$ Mediana $(2-4)$

$\square$ Alta (5-8)

$\square$ Muy Alta (9-20)

Figura 6.33: Frecuencia de inundación gradual y brusca por municipio (1980-2010). Fuente: Elaboración propia con los datos de Hermann (2014).

Un ejemplo de una inundación brusca que ocurrió en enero de 2018. Degradó múltiples calles 
y edificaciones en la zona del manglar del Río Tavares, tal como se observa en la Figura 6.34. Este problema se debe a la ocupación urbana y a la impermeabilización del suelo en zonas que originalmente eran de manglares, cuya característica principal es que son terrenos inundados.

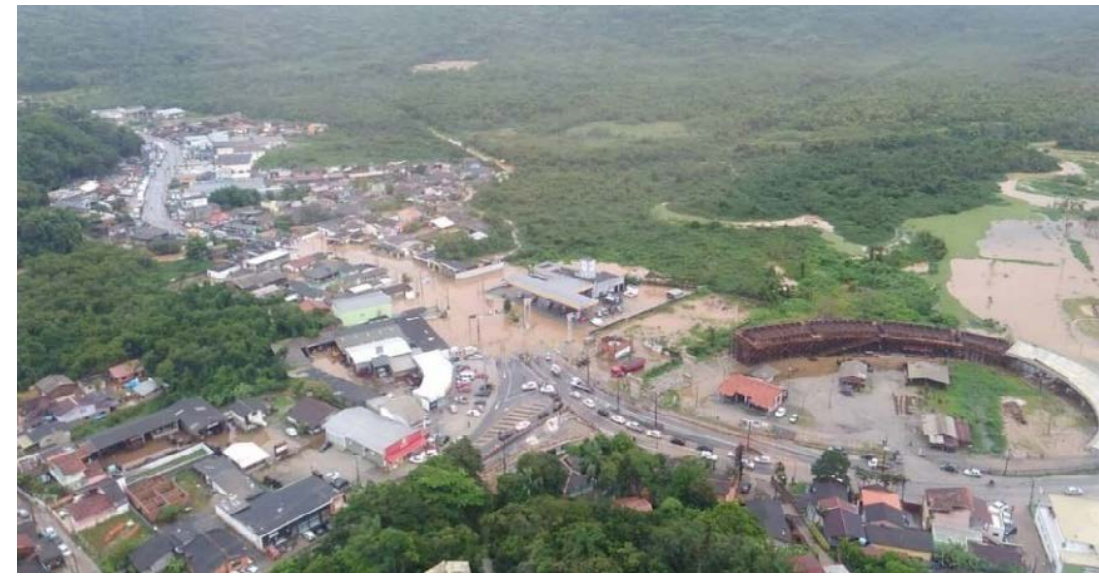

Figura 6.34: Inundación brusca en el manglar del Río Tavares. Fuente: Cuerpo de Bomberos de Santa Catarina $^{58}$.

Además de las inundaciones graduales y bruscas, existen también las inundaciones por el aumento de las mareas acompañada de fuertes lluvias, causadas por las tormentas. Este factor de impacto es de gran importancia, principalmente en las áreas ocupadas muy cerca de la costa. En el período entre 1997 y 2010, el Municipio de Florianópolis registró cerca de seis sucesos asociados a esta problemática, encontrándose el mayor número en los municipios de la costa del Estado de Santa Catarina (Rudorff et al., 2014, p. 153).

\subsubsection{Contaminación del aire, agua y suelo}

La contaminación se distribuye en todo el territorio de la Región Metropolitana de Florianópolis con intensidades y tipos variables, de acuerdo con el modo de uso del suelo para cada lugar. Donde predomina la práctica de la agricultura, en los municipios menos poblados, como Santo Amaro da Imperatriz, Governador Celso Ramos, Águas Mornas, Antônio Carlos y São Pedro de Alcântara, la contaminación proviene principalmente del uso de los pesticidas y fertilizantes que se propagan por el aire, el agua y el suelo, intoxicando los ecosistemas. Su utilización afecta a los microorganismos (hongos, bacterias y algas), las poblaciones de insectos, los vertebrados, así como a una gran variedad de plantas (Sevegnani y Schroeder, 2013, p. 205).

\footnotetext{
58 Visualizado en UOL Notícias. Disponible en https://noticias.uol.com.br/ (fecha de consulta: enero de 2018).
} 
En los municipios más urbanizados, como Florianópolis, São José, Palhoça y Biguaçu, la contaminación del aire se da por los gases tóxicos. Proceden del incremento del uso del vehículo y de las industrias, que generan problemas de salud humana, igual que propician el efecto invernadero y contribuyen al calentamiento global. En estos municipios, el incremento de desplazamientos por carretera alcanza su punto máximo durante el período de verano, donde la mayoría de los turistas vienen con sus vehículos particulares, lo que denota un sistema de movilidad pública precario y poco eficiente.

La contaminación del agua en las zonas urbanizadas sucede principalmente por los efluentes residuales industriales y domésticos depositados en los cursos de agua sin un tratamiento previo. Cuando hay tratamiento, muchas veces, los problemas son originarios por la capacidad limitada en la reducción de los contaminantes. Los manglares son uno de los ecosistemas más afectados por estar en contacto directamente con los ríos y mares contaminados, causando la muerte de diversas especies de la fauna, además de perjudicar la salud pública por el contacto del agua no tratada.

El Estado de Santa Catarina es considerado uno de los peores en el servicio de recolección de aguas residuales a nivel nacional y el peor de la Región Sur del País, con un promedio del $10 \%$ a $20 \%$ de cobertura, según los datos del Sistema Nacional de Informações Sobre Saneamento (SINS, 2011). El mejor índice se registró en el Municipio de Florianópolis, con un $55,4 \%$, seguido de São José con un 33,9\% y Palhoça con un 4,4\% (SINS, 2011). El restante de población utiliza fosas sépticas o formas inadecuadas (fosa rudimentaria, acequia, río, lago, mar) para depositar las aguas residuales que se producen.

En cuanto a los residuos de basura, su destino final es ser depositados como vertederos. Por lo general, el volumen de estos residuos es demasiado grande por la falta de reciclaje y reutilización. Estos vertederos generan impactos sobre el ecosistema circundante, proliferando ratas, insectos, mal olor y el estiércol, que contaminan los suelos, los cursos de agua, y también provocan riesgos de explosiones debido al gas producido por la fermentación de la materia orgánica depositada durante los años.

El vertedero que recoge los residuos de basura de la Región Metropolitana de Florianópolis, además de otros municipios cercanos, se ubica en el Municipio de Biguaçu. Conforme los datos de IBGE (2011), solamente para el Municipio de Florianópolis, se estima una cantidad de más de 500 toneladas/día, que se destina a Biguaçu.

Antes de la utilización del vertedero de Biguaçu, el Municipio de Florianópolis depositaba sus residuos en un área ubicada en el manglar de Itacorubi (inaugurado en el año de 1958, debido 
el crecimiento demográfico), lo que agredía fuertemente este ecosistema. Recibía diariamente cerca de 130 toneladas de basura y generaba alteraciones tanto químicas en las aguas de los ríos y mares, como también en la fauna y la flora (Caruso, 1983, p. 121). La continuidad del depósito, con el tiempo, se convirtió en inviable, generando protestas de los residentes cerca y también movimientos ecológicos (Ramos, 1986, p. 83), que perduró hasta 1989.

A partir del año 2000, este escenario ha cambiado con la inauguración del Centro de Transferencia de Residuos Sólidos, que es un sistema de gestión y limpieza de residuos sólidos, y también la reforestación de las zonas fronterizas del manglar de Itacorubi, promoviendo su regeneración. Sin embargo, todavía se observa el depósito de residuos en algunos puntos de los manglares de la Región Metropolitana, que comprueba la negligencia de los habitantes y la falta de fiscalización ambiental, según se muestra en la Figura 6.35.
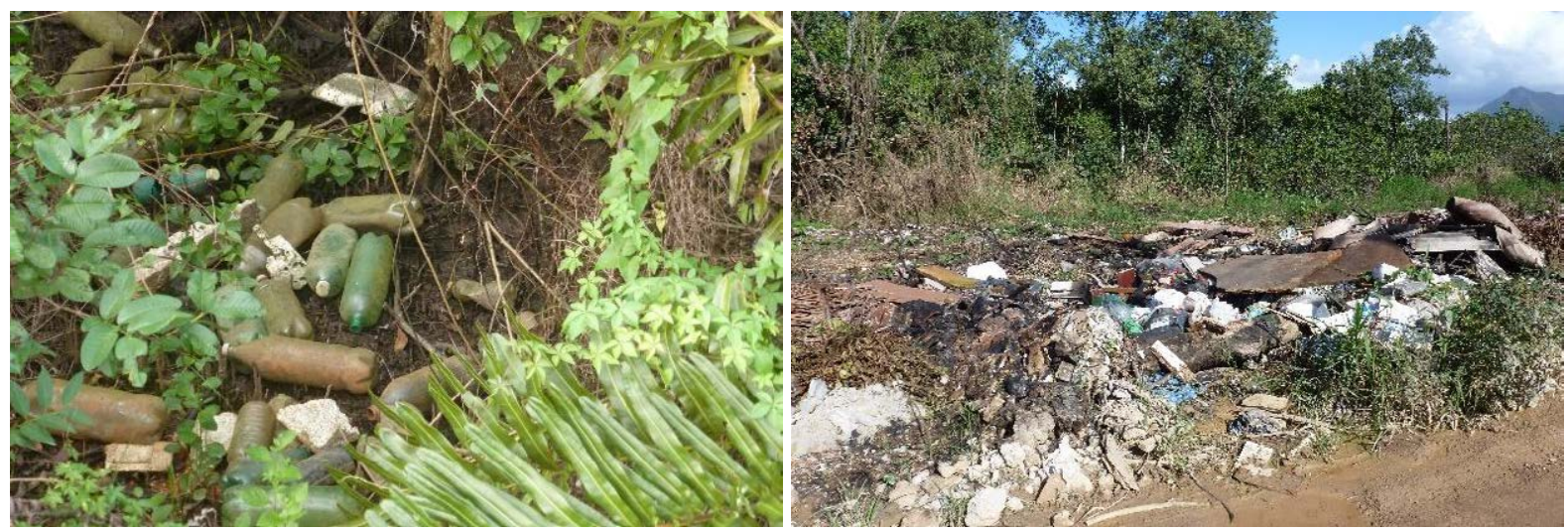

Figura 6.35: Residuos de basura ubicados en los manglares de Itacorubi y de Palhoça, respectivamente. Fuente: Archivo de la autora (2017).

\subsubsection{Cambio climático}

Los efectos del cambio climático en curso, debido al efecto invernadero por las emisiones de gases tóxicos en la atmósfera, serán cada vez más frecuentes y con mayor intensidad si no son reducidas. Los impactos afectan en numerosas escalas, de la local hasta la global, y provocan consecuencias para los ecosistemas y la población humana, especialmente en las zonas cerca del mar, como el caso de la Región Metropolitana de Florianópolis.

Debido al calentamiento, se espera que aumenten en los próximos años eventos climáticos como las tormentas, los fenómenos El Niño y La Niña, el crecimiento excepcional de las mareas y los ciclones (EISMA, 1995). Todos los escenarios proyectados por el Intergovernmental Panel on Climate Change (IPCC) indican también un aumento del nivel del mar. En este caso, la Región Metropolitana se coloca como zona de alto riesgo de impacto, con intensas inundaciones, que afectan principalmente a la aglomeración poblacional en las 
zonas más próximas a la costa y cerca de los manglares.

En cuanto a los ecosistemas, las consecuencias de este impacto pueden afectar a las cadenas alimentarias (plantas y animales disponibles para servir de alimentos), la fenología de las plantas (período de fructificación, la floración y el crecimiento) y su sincronización con los ritmos biológicos de los animales (Sevegnani y Schroeder, 2013, p. 197). En el caso de los manglares, por ser un ecosistema costero, la situación se empeoraría, pues el aumento del nivel del mar en un período muy corto podría causar la desaparición del mismo, a diferencia de las fluctuaciones graduales de los océanos que se han producido con el tiempo, teniendo el restablecimiento natural de los manglares.

\subsubsection{Evaluación de los impactos ambientales}

La evaluación de los impactos ambientales se define según el procedimiento que determina la valoración de cada factor de impacto. En Brasil, está establecida a través de la Resolución del Consejo Nacional del Medio Ambiente (Conama) $n^{\circ} 001 / 1986^{59}$, a partir de la identificación, previsión de la magnitud e interpretación de la importancia de los probables impactos relevantes. Según la normativa europea ${ }^{60}$, los parámetros de valoración deben llevar en consideración la extensión del área geográfica y tamaño de la población afectada, el carácter transfronterizo, la magnitud y complejidad, la probabilidad, la duración, frecuencia y reversibilidad del impacto.

Existe una variedad de parámetros para el análisis individual de cada impacto, que puede ser cualitativa o cuantitativa. La cualitativa evalúa de forma subjetiva los impactos ambientales con valores prefijados. La cuantitativa exige un proceso más elaborado de investigación, a través de la medición de la magnitud del impacto, como ejemplo, la determinación de los valores de contaminación del agua por la cantidad de sustancias contaminantes. Debido a la ausencia de los índices de la mayoría de los impactos, este estudio se limitó a un análisis cualitativo en cuatro aspectos, en lo que se refiere a su espacialidad, persistencia, reversibilidad y recuperación, detallados a continuación:

1. Espacialidad (puntual, parcial, extensa): área de influencia de un determinado factor de impacto. La espacialidad puntual se refiere a un impacto muy localizado, la parcial supone

${ }^{59}$ Brasil (1986). Conselho Nacional do Meio Ambiente. Ministério do Meio Ambiente (Conama), Resolução $n^{\circ}$ $001 / 1986$.

60 Unión Europea (1997). Directiva 97/11/CE del Consejo de 3 de marzo de 1997, por la que se modifica la Directiva 85/337/CEE relativa a la evaluación de las repercusiones de determinados proyectos públicos y privados sobre el medio ambiente. 
una amplitud considerable en el territorio y la extensa alcanza la totalidad del territorio.

2. Persistencia (temporal y permanente): tiempo que lleva un impacto tras cesar la acción. La persistencia temporal es un periodo de corto o medio plazo y la permanente, de largo plazo $^{61}$. Todos los factores temporales también son considerados reversibles y recuperables.

3. Reversibilidad (reversible e irreversible): tras cesar la acción, el medio tiene o no la capacidad de volver a su estado original a corto o medio plazo, sin medidas correctoras, siendo reversible o irreversible, respectivamente. Todos los factores reversibles también son considerados recuperables.

4. Recuperabilidad (recuperable e irrecuperable): tras cesar la acción, el medio tiene o no la capacidad de volver a su estado original a corto o medio plazo, utilizando o no medidas correctoras, siendo recuperable o irrecuperable, respectivamente.

Conforme la Tabla 6.4, se analiza cada factor de impacto independiente, de acuerdo con los parámetros seleccionados:

\begin{tabular}{|l|c|c|c|c|}
\hline \multicolumn{1}{|c|}{ Factores de impacto } & Espacialidad & Persistencia & Reversibilidad & Recuperbilidad \\
\hline $\begin{array}{l}\text { Pérdida y fragmentación } \\
\text { de la vegetación }\end{array}$ & Parcial & Permanente & Irreversible & Recuperable \\
\hline $\begin{array}{l}\text { Plantación de especies } \\
\text { exóticas }\end{array}$ & Puntual & Permanente & Irreversible & Recuperable \\
\hline Inundación & Puntual & Permanente & Irreversible & Recuperable \\
\hline $\begin{array}{l}\text { Contaminación del aire, } \\
\text { agua y suelo }\end{array}$ & Parcial & Permanente & Irreversible & Recuperable \\
\hline Cambio climático & Extensa & Permanente & Irreversible & Irrecuperable \\
\hline
\end{tabular}

Tabla 6.4: Evaluación de los impactos ambientales. Fuente: Elaboración propia.

En relación a la espacialidad, la pérdida y fragmentación de la vegetación y la contaminación ocupan grandes áreas territoriales, siendo consideradas como espacialidad parcial. La primera está referida principalmente a las superficies llanas, por la ocupación humana en estas áreas, y la segunda está presente donde hay la ocupación rural y urbana. Por otro lado, la plantación de especies exóticas y la inundación se manifiestan de forma puntual en el territorio, situándose principalmente en las áreas con vegetación de restinga y también a lo largo de los ríos, cerca del mar y manglares, respectivamente. En cuanto al cambio climático, este factor de impacto está considerado como espacialidad extensa por alcanzar el nivel

${ }^{61}$ En este estudio se considera corto plazo un periodo de hasta cinco años; medio plazo, hasta diez años; y largo plazo, supera los diez años. 
global.

Todos los impactos de estudio tienen el carácter permanente e irreversible, pues el tiempo de persistencia, así como la reversibilidad, en general, superan los diez años. Sin embargo, con la utilización de medidas protectoras y correctoras, estos impactos se vuelven recuperables a corto o medio plazo, con la excepción del cambio climático. Este último factor está considerado como un impacto extremo, donde no hay una medida correctora a corto o medio plazo, sino medidas paliativas para disminuir sus consecuencias.

\subsection{CARACTERIZACIÓN ESPACIAL DE LOS PAISAJES DE MANGLARES}

Los paisajes de manglares, tal como se encuentran espacialmente, son resultados de los factores naturales y humanos. En esta sección primero se analizan temporalmente los cambios que han sufrido las nueve formaciones de manglares existentes en la Región Metropolitana de Florianópolis, como consecuencia de la interrelación de los factores a lo largo de la historia. Posteriormente, a través de la comprensión del análisis temporal, se hace posible caracterizar espacialmente estos paisajes de forma cualitativa, identificando su dinámica y ordenamiento en el momento actual.

\subsubsection{Análisis temporal}

Para el análisis temporal se cuantificaron las áreas de los nueve manglares de la Región Metropolitana de Florianópolis a través de la verificación temporal de los años de 1938 , 1956/1957, 1978 y 2015 (Tabla 6.5). Para obtener los datos históricos de las áreas, se utilizaron distintas referencias, por lo tanto, la precisión puede variar debido a la interpretación individual de cada autor. Para el registro de las áreas de 2015, se usó el mapa del Centro de Informação de Recursos Ambientais e de Hidrometeorologia de Santa Catarina (CIRAM) más reciente, en este caso perteneciente a 2005, y se relacionó con las imágenes de satélite de 2015. Es importante mencionar que la poca cantidad de datos por año que se ha conseguido dificulta aún más la precisión de los análisis. En cuanto al manglar de Massiambu, no se obtuvo información histórica, posiblemente por haber sido poco afectado. Sobre el manglar de Aririú-Cubatão y el del Río Biguaçu, no hay resultados referentes al año 1938. 


\begin{tabular}{|c|c|c|c|c|c|c|}
\hline & \multirow{2}{*}{ Manglares } & \multirow{2}{*}{ Municipios } & \multicolumn{4}{|c|}{ Áreas de los manglares $\left(\mathrm{Km}^{2}\right)$} \\
\hline & & & 1938 & $1956 / 1957$ & 1978 & 2015 \\
\hline & 1. Río Ratones & Florianópolis & $12,26(a)$ & $13,52(b)$ & $9,95(a)$ & $13,19(f)$ \\
\hline & 2. Saco Grande & Florianópolis & $1,23(a)$ & $1,21(b)$ & $1,10(a)$ & $1,06(f)$ \\
\hline & 3. tacorubi & Florianópolis & $2,38(a)$ & $2,15(b)$ & $2,44(a)$ & $2,02(f)$ \\
\hline & 4. Río Tavares & Florianópolis & $14,67(a)$ & $14,22(b)$ & 7,65 (a) & 7,12 (f) \\
\hline & 5. Tapera & Florianópolis & $0,40(a)$ & $0,74(b)$ & $0,53(a)$ & $0,50(f)$ \\
\hline Atlántico & 6. Río Biguaçu & Biguaçu & - & $0,32(\mathrm{e})$ & $0,38(e)$ & 0,47 (f) \\
\hline & 7. Palhoça & Palhoça & 3,45 (c) & 3,41 (c) & 2,83 (c) & $2,95(f)$ \\
\hline & 8. Aririú-Cubatão & Palhoça & - & $7,09(\mathrm{c}, \mathrm{d})$ & $6,37(\mathrm{c}, \mathrm{d})$ & $5,84(\mathrm{f})$ \\
\hline & 9. Massiambu & Palhoça & - & - & - & $4,23(f)$ \\
\hline
\end{tabular}

Tabla 6.5: Cuantificación temporal de los manglares. Fuente: Elaboración propia, a partir de las referencias de: (a) Trindade (2009), (b) Nascimento (1989), (c) Lopes (1999), (d) Espírito Santo (2004), (e) Baratella y Menezes (2011), (f) CIRAM (2005) e imagen de satélite (2015).

Como se puede observar en la tabla anterior, ha habido una disminución en la mayoría de los manglares desde el año 1938 hasta 2015. Considerando los manglares con informaciones en todos los años (Río Ratones, Saco Grande, Itacorubi, Río Tavares, Tapera y Palhoça), se verificó que en el año de 1938 ocupaban un área de $34,39 \mathrm{~km}^{2}$ de manglares, y en el año de 2015 , un área de $26,84 \mathrm{~km}^{2}$, totalizando una pérdida de cerca de un $22 \%$, con una velocidad de reducción de aproximadamente $0,1 \mathrm{~km}^{2} / a n ̃ o$. Estos datos revelan una fuerte relación de la ocupación humana con las perdidas ambientales. Según Díaz-Palacios-Sisternes et al. (2014), es a través del conocimiento de la dinámica del uso del suelo que se puede cuantificar los impactos en el paisaje.

Aunque existen datos solamente a partir de 1938, consta históricamente la pérdida de vegetación por la influencia de la agricultura desde el siglo XVIII, lo que ha tenido como resultado la desaparición de gran parte de los bosques hasta el inicio del siglo XX. Sin embargo, en el año de 1938 ya se manifiesta el restablecimiento de la vegetación con el abandono de las prácticas agrícolas, según las referencias documentadas.

Entre los años de 1938 y 1956/1957 se percibe un aumento de los manglares del Río Ratones y de Tapera. Este hecho se puede explicar por el declive de la agricultura y la ganadería, lo que llevó consigo la regeneración natural de las áreas de manglares. Otro aspecto en relación con la recuperación de estas áreas, es el hecho de contar con grandes extensiones de llanuras, diferentes a las de la zona central de la isla, donde son llanuras pequeñas y con colinas en su entorno.

El caso del manglar del Río Tavares, entre 1938 y 1956/1957, ubicado en el Sur de la isla, a 
pesar de que tiene también una gran área de llanura, hubo una disminución del manglar como consecuencia de la construcción del aeropuerto de la Región Metropolitana. En los manglares centrales del Municipio de Florianópolis, como el de Saco Grande y el de Itacorubi, y del Municipio de Palhoça, el manglar de Palhoça, todavía se observa una tendencia de descenso, probablemente debida a la práctica de la agricultura y la ganadería.

Entre 1956/1957 y 1978, se produjo una disminución en la mayoría de los manglares. Sin embargo, en el manglar de Itacorubi se aprecia, por el contrario, un aumento, resultante de la regeneración natural de los manglares gracias al inicio de la urbanización que se produjo en esta área y la disminución de la práctica agrícola y ganadera.

Ya a partir de la década de 1978 hasta nuestros días, por causa del gran crecimiento poblacional y económico territorial, se redujeron la mayoría de los manglares. En cuanto a los manglares de Río Ratones, Biguaçu y Palhoça, se observó el restablecimiento de los manglares, al mismo tiempo que se redujo la actividad de agricultura y ganadería y se intensificó la urbanización en estas áreas. Probablemente, una situación similar tuvo lugar en el manglar de Massiambu, pero por la falta de datos históricos, el análisis resulta incompleto.

En un aspecto general, a pesar de que los manglares se encuentran todavía, en algunos lugares, en regeneración natural por la decadencia de la agricultura y la ganadería, puede afirmarse claramente que la urbanización densa, sin planeamiento adecuado y sin respeto a las leyes de conservación ambiental, ha mostrado una tendencia a la devastación con resultados más destructivos.

\subsubsection{Caracterización espacial}

La caracterización espacial de los nueve paisajes de manglares de la Región Metropolitana es el resultado estructural de los factores naturales y humanos para el momento actual. Los factores naturales son determinados por los manglares y la vegetación próxima; y los factores humanos, por la ocupación del suelo a través de la superficie agrícola y/o ganadera (en utilización o abandonada en proceso de regeneración natural), la acuicultura, el área urbanizada (edificaciones y calles locales) y las carreteras de tráfico rápido, según muestra la Figura 6.36. 


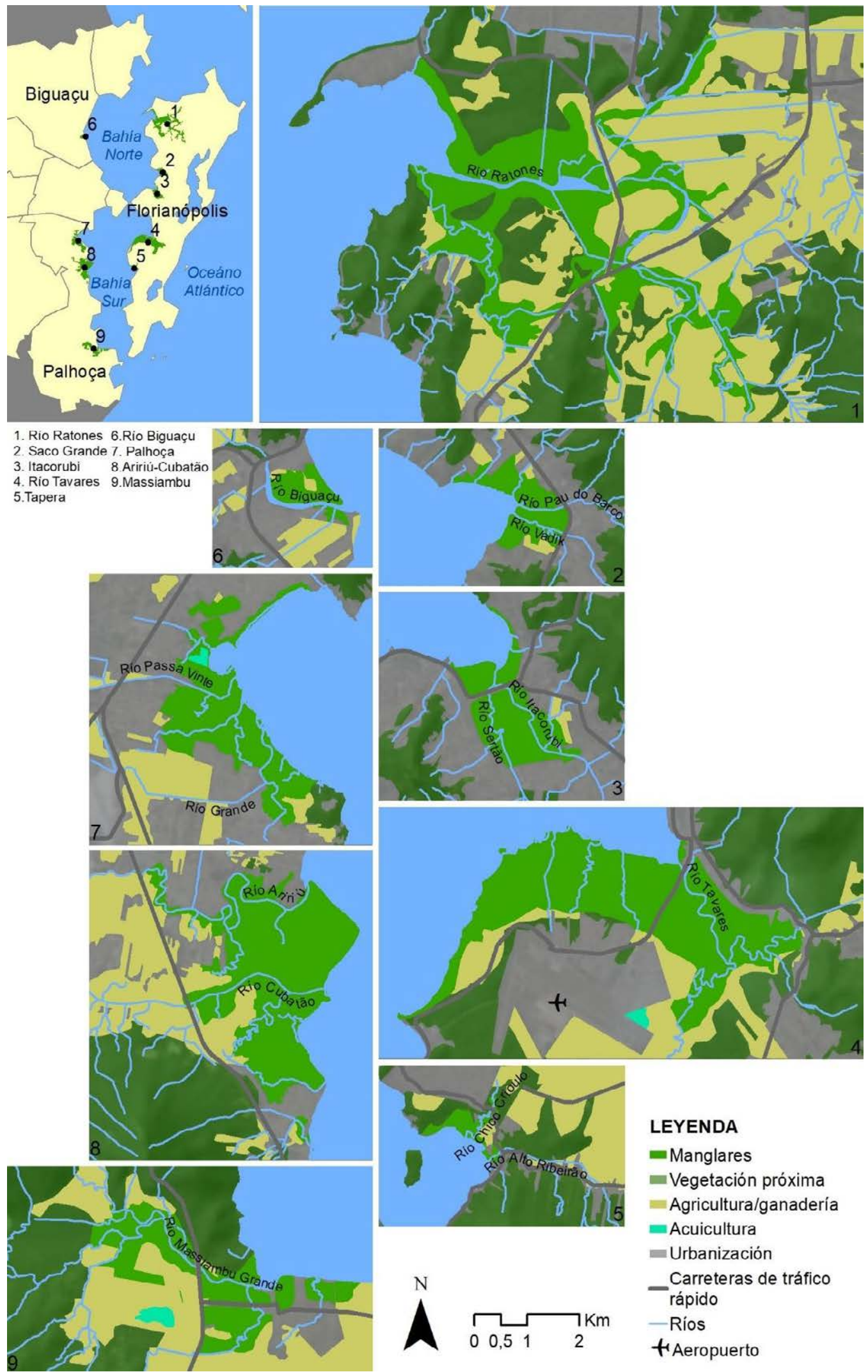

Figura 6.36: Caracterización espacial. Fuente: Elaboración propia con los datos de CIRAM (2005) y las imágenes de satélite de 2015. 
El análisis se realizó de forma cualitativa, mediante la elaboración de fichas de caracterización. Las fichas están divididas en dos partes, diferenciándose en los datos básicos y la caracterización espacial del paisaje de manglar.

Los datos básicos se verifican en la Figura 6.37, determinados en los siguientes puntos:

- Nombre del manglar.

- Área aproximada.

- Situación: Municipio.

- Localización: Latitud y Longitud.

- Coordenada (WGS 1984 UTM Zona 22S): Coordenada X y Coordenada Y.

- Protección ambiental: figuras de protección ambiental de los manglares.

- Mapa de situación y localización: se elaboró mediante el mapa de CIRAM (2005), las imágenes de satélite de 2015 y la visita de campo.

- Estado previo (1978) y estado actual (2015): las fotos aéreas de 1978 fueron obtenidas a través de la Secretaría del Planeamiento del Estado de Santa Catarina (Directorio de Estadística y Cartografía), y las de 2015, por imágenes satélites del Google Earth. 


\section{DATOS BÁSICOS}

Nombre del manglar:

Área aprox. $\left(\mathrm{Km}^{2}\right)$ :

\begin{tabular}{ll}
\hline Situación & Municipio: \\
\hline Localización & Latitud: \\
& Longitud: \\
\hline Coordenada & Coordenada $X$ \\
WGS 1984 UTM Zona 22S & Coordenada $Y:$ \\
\hline
\end{tabular}

Protección ambiental:

Mapa de situación y localización

Estado previo (1978) y estado actual (2015)

Figura 6.37: Ficha de caracterización: datos básicos. Fuente: Elaboración propia. 
La caracterización del paisaje de manglar identifica los factores naturales y humanos, según se observa en la Figura 6.38, determinados por los siguientes aspectos:

- Factores naturales: tienen como objetivo principal verificar la estructura del manglar dentro del paisaje a través de su forma y su relación con la vegetación próxima. Los puntos que caracterizan los factores naturales son:

$\checkmark$ Nombre del río principal.

$\checkmark$ Nombre de la microcuenca donde está inserido el manglar.

$\checkmark$ Forma del manglar: regular, semi regular o irregular.

$\checkmark$ Tipo de conexión del manglar con la vegetación próxima: parcialmente conectado, poco conectado, muy poco conectado o aislado.

- Factores humanos: tienen como objetivo principal identificar la fragmentación del manglar a través de los elementos antrópicos presentes en el paisaje. Los puntos que caracterizan los factores humanos son:

$\checkmark$ Fragmentación del manglar: si está fragmentado o no fragmentado.

$\checkmark$ Número de fragmentación del manglar: entre 1 a 5 .

$\checkmark$ Elemento(s) de fragmentación del manglar: agricultura/ganadería, urbanización, acuicultura y carreteras.

$\checkmark$ Elemento(s) de fragmentación del manglar con la vegetación próxima: agricultura/ganadería, urbanización, acuicultura y carreteras.

Uso del suelo predominante: agricultura/ganadería, urbanización o ambos semejantes. 


\section{CARACTERIZACIÓN ESPACIAL DEL PASAJE DE MANGLAR}

\section{FACTORES NATURALES}

Río(s) principal(es):

Microcuenca(s):

Forma del manglar:

$\square$ Regular
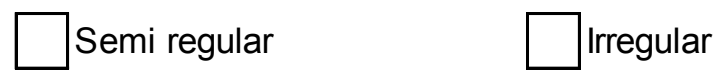

Conexión del manglar con la vegetación próxima:

$\begin{array}{ll}\square \text { Parcialmente conectado } & \square \text { Muy poco conectado } \\ \square \text { Poco conectado } & \square \text { Aislado }\end{array}$

\section{FACTORES HUMANOS}

Fragmentación del manglar:

$\square$ Fragmentado $\square$ No fragmentado

Número de fragmentación del manglar:

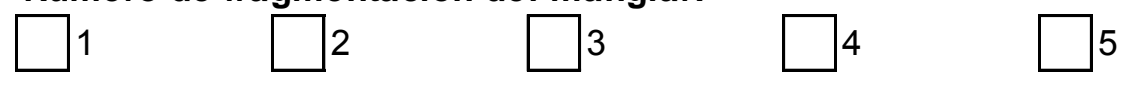

Elemento(s) de fragmentación del manglar:

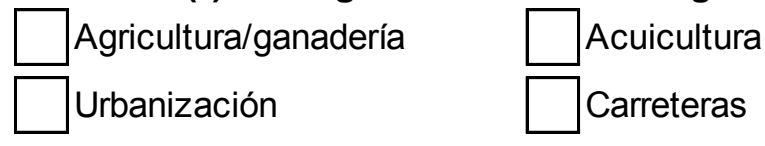

Elemento(s) de fragmentación del manglar con la vegetación próxima:

$\begin{array}{ll}\square \text { Agricultura/ganadería } & \square \text { Acuicultura } \\ \square \text { Urbanización } & \square \text { Carreteras }\end{array}$

Uso del suelo predominante:

Agricultura/ganadería $\square$ Urbanización $\square$ Ambos

Figura 6.38: Ficha de caracterización: caracterización espacial del paisaje de manglar. Fuente: Elaboración propia.

Las fichas de caracterización de los nueve manglares están representadas a continuación desde la Figura 6.39 hasta la Figura 6.47. 


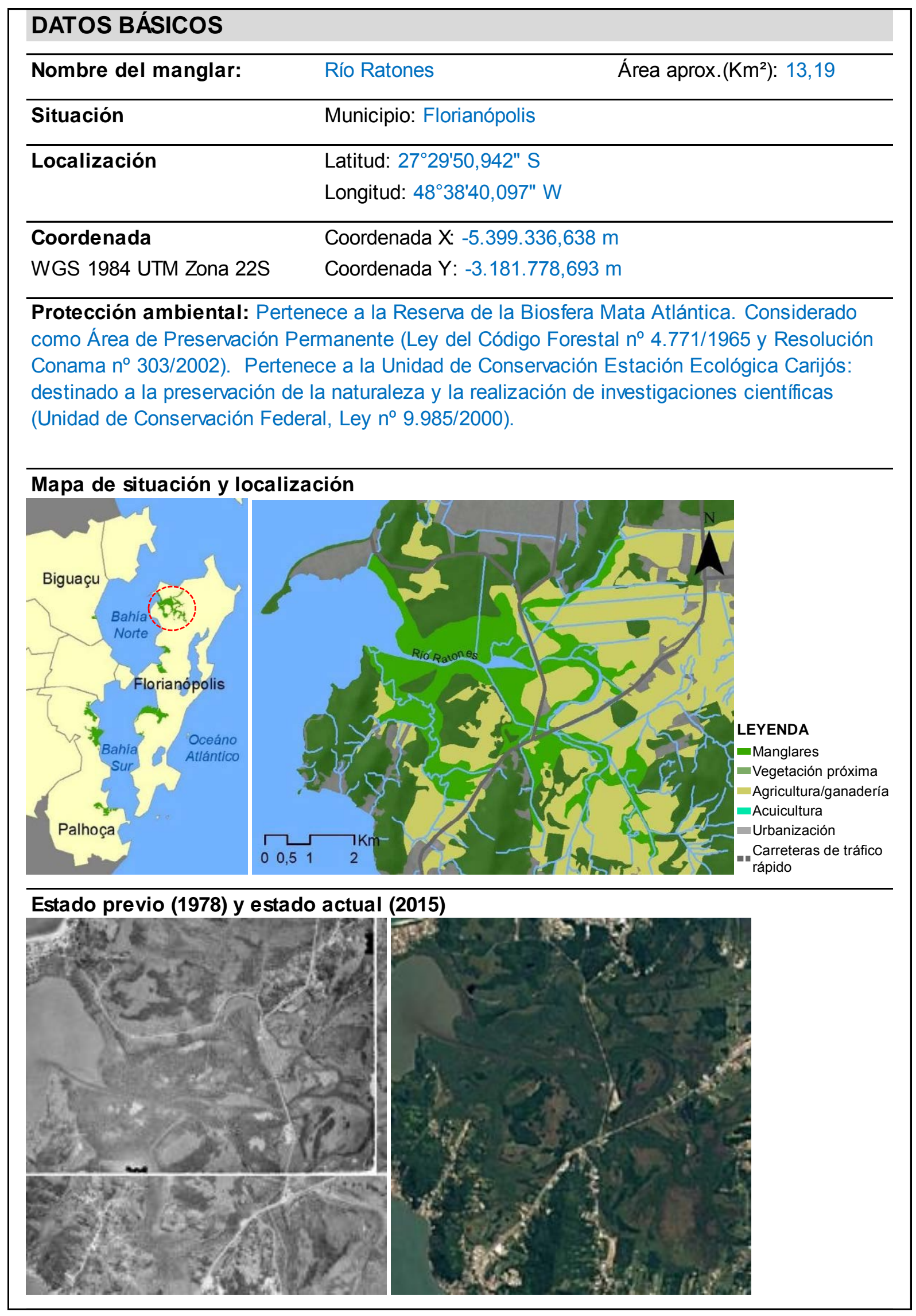




\section{CARACTERIZACIÓN ESPACIAL DEL PAISAJE DE MANGLAR}

\section{FACTORES NATURALES}

Río(s) principal(es):

Río Ratones

Microcuenca(s):

Río Ratones

Forma del manglar:

$\square$ Regular

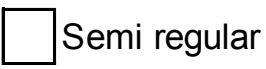

$\mathrm{X}$ Irregular

Conexión del manglar con la vegetación próxima:

$\mathrm{X}$ Parcialmente conectado

Poco conectado

$\square$ Muy poco conectado
$\square$ Aislado

\section{FACTORES HUMANOS}

Fragmentación del manglar:

$\mathrm{X}$ Fragmentado No fragmentado

Número de fragmentación del manglar:

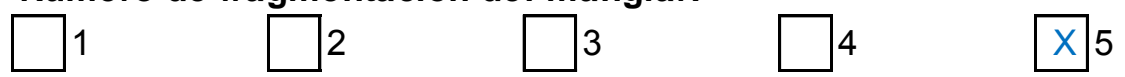

Elemento(s) de fragmentación del manglar:
Agricultura/ganadería
$\square$ Acuicultura
Urbanización
$\mathrm{X}$ Carreteras

Elemento(s) de fragmentación del manglar con la vegetación próxima:

$\mathrm{X}$ Agricultura/ganadería

$X$ Urbanización

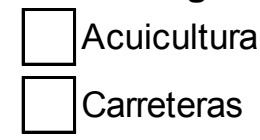

Uso del suelo predominante:

X Agricultura/ganadería $\square$ Urbanización $\square$ Ambos

Figura 6.39: Ficha de caracterización del manglar del Río Ratones. Fuente: Elaboración propia. 


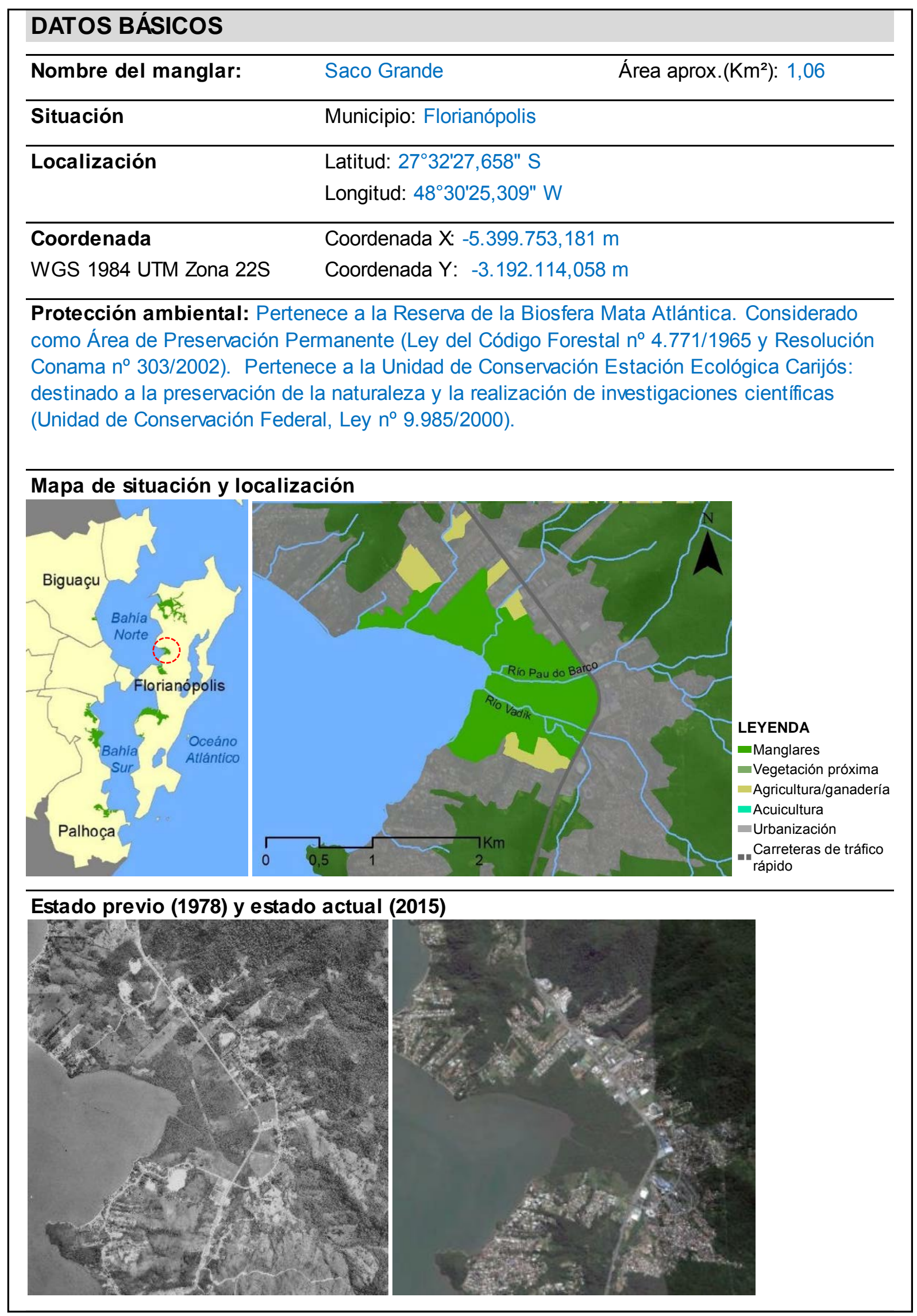




\section{CARACTERIZACIÓN ESPACIAL DEL PAISAJE DE MANGLAR}

\section{FACTORES NATURALES}

Río(s) principal(es):

Río Vadik

Microcuenca(s):

\section{Saco Grande}

Forma del manglar:

$\mathrm{X}$ Regular
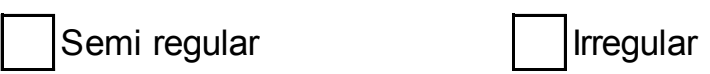

Conexión del manglar con la vegetación próxima:

$\begin{array}{ll}\square \text { Parcialmente conectado } & \square \text { Muy poco conectado } \\ \square \text { Poco conectado } & \mathrm{X} \text { Aislado }\end{array}$

\section{FACTORES HUMANOS}

Fragmentación del manglar:

$\square$ Fragmentado $\quad X$ No fragmentado

Número de fragmentación del manglar:

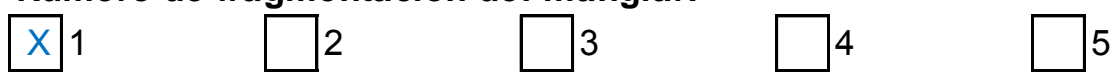

Elemento(s) de fragmentación del manglar:
$\square$ Agricultura/ganadería
$\square$ Acuicultura
$\square$ Urbanización
Carreteras

Elemento(s) de fragmentación del manglar con la vegetación próxima:

\begin{tabular}{ll}
\hline Agricultura/ganadería & $\square$ Acuicultura \\
\hline $\mathrm{X}$ Urbanización & $\square$ Carreteras
\end{tabular}

Uso del suelo predominante:
Agricultura/ganadería
X Urbanización
Ambos

Figura 6.40: Ficha de caracterización del manglar de Saco Grande. Fuente: Elaboración propia. 


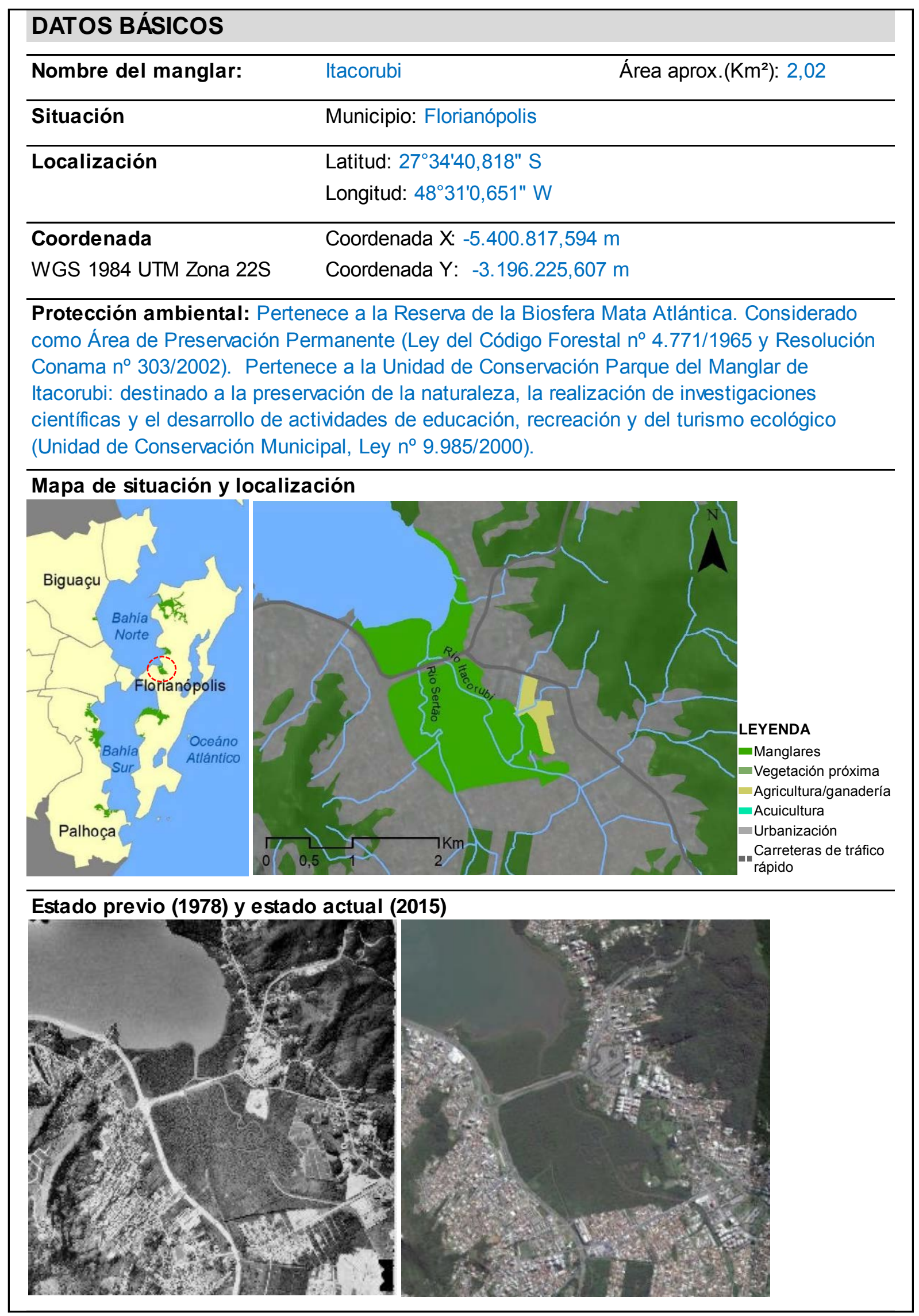




\section{CARACTERIZACIÓN ESPACIAL DEL PAISAJE DE MANGLAR}

\section{FACTORES NATURALES}

Río(s) principal(es):

Río Itacorubi

Microcuenca(s): Itacorubi

Forma del manglar:

$\mathrm{X}$ Regular
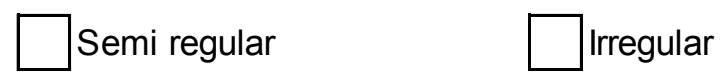

Conexión del manglar con la vegetación próxima:

$\begin{array}{ll}\square \text { Parcialmente conectado } & \square \text { Muy poco conectado } \\ \square \text { Poco conectado } & \mathrm{X} \text { Aislado }\end{array}$

\section{FACTORES HUMANOS}

Fragmentación del manglar:

$\mathrm{X}$ Fragmentado No fragmentado

Número de fragmentación del manglar:

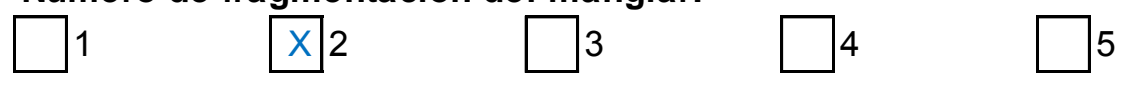

Elemento(s) de fragmentación del manglar:
$\square$ Agricultura/ganadería
$\square$ Acuicultura
$\square$ Urbanización
$\mathrm{X}$ Carreteras

Elemento(s) de fragmentación del manglar con la vegetación próxima:

\begin{tabular}{ll}
\hline Agricultura/ganadería & $\square$ Acuicultura \\
\hline $\mathrm{X}$ Urbanización & $\square$ Carreteras
\end{tabular}

Uso del suelo predominante:
Agricultura/ganadería
X Urbanización Ambos

Figura 6.41: Ficha de caracterización del manglar de Itacorubi. Fuente: Elaboración propia. 


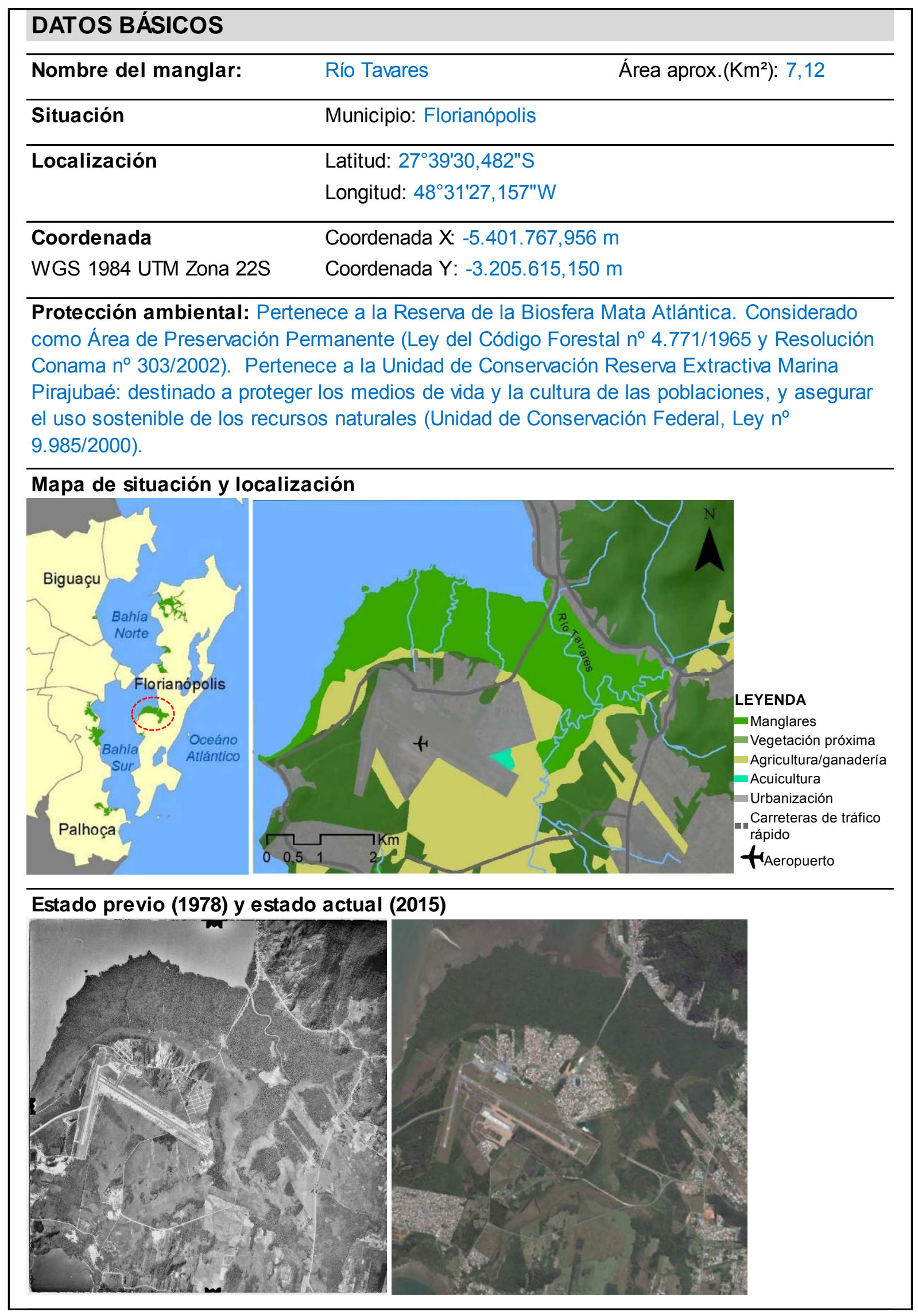




\section{CARACTERIZACIÓN ESPACIAL DEL PAISAJE DE MANGLAR}

\section{FACTORES NATURALES}

Río(s) principal(es):

Río Tavares

Microcuenca(s):

Río Tavares

Forma del manglar:

$\square$ Regular

$\mathrm{X}$ Semi regular

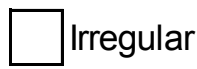

Conexión del manglar con la vegetación próxima:

$\begin{array}{ll}\square \text { Parcialmente conectado } & X \text { Muy poco conectado } \\ \square \text { Poco conectado } & \square \text { Aislado }\end{array}$

\section{FACTORES HUMANOS}

Fragmentación del manglar:

$\mathrm{X}$ Fragmentado No fragmentado

Número de fragmentación del manglar:

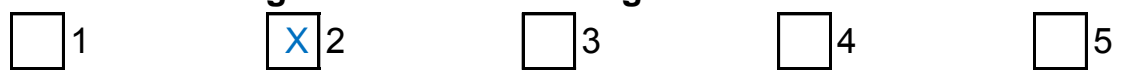

Elemento(s) de fragmentación del manglar:
$\square$ Agricultura/ganadería
$\square$ Acuicultura
X Urbanización
$\mathrm{X}$ Carreteras

Elemento(s) de fragmentación del manglar con la vegetación próxima:

X Agricultura/ganadería

$\mathrm{X}$ Urbanización

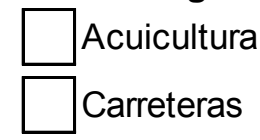

Uso del suelo predominante:
Agricultura/ganadería
Urbanización
$\mathrm{X}$ Ambos

Figura 6.42: Ficha de caracterización del manglar del Río Tavares. Fuente: Elaboración propia. 


\begin{tabular}{|c|c|}
\hline \multicolumn{2}{|l|}{ DATOS BÁSICOS } \\
\hline Nombre del manglar: & Área aprox. $\left(\mathrm{Km}^{2}\right): 0,50$ \\
\hline Situación & Municipio: Florianópolis \\
\hline \multirow[t]{2}{*}{ Localización } & Latitud: $27^{\circ} 41^{\prime} 43,5^{\prime \prime} \mathrm{S}$ \\
\hline & Longitud: $48^{\circ} 33^{\prime} 13,184^{\prime \prime} \mathrm{W}$ \\
\hline Coordenada & Coordenada X: $-5.404 .776,339 \mathrm{~m}$ \\
\hline WGS 1984 UTM Zona 22S & Coordenada Y: $-3.210 .909,847 \mathrm{~m}$ \\
\hline
\end{tabular}

Protección ambiental: Pertenece a la Reserva de la Biosfera Mata Atlántica. Considerado como Área de Preservación Permanente (Ley del Código Forestal n 4.771/1965 y Resolución Conama $n^{\circ}$ 303/2002).
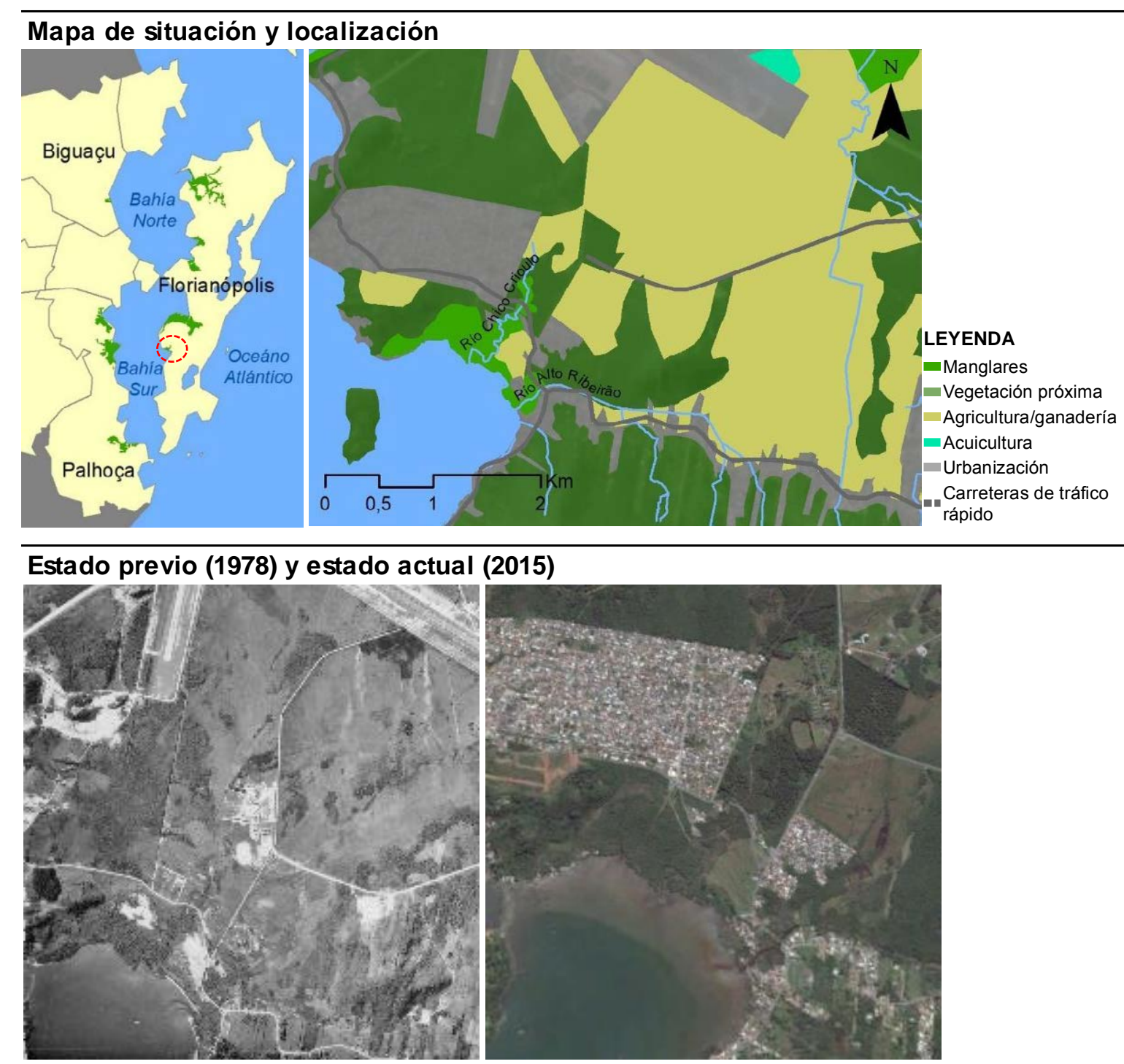


\section{CARACTERIZACIÓN ESPACIAL DEL PAISAJE DE MANGLAR}

\section{FACTORES NATURALES}

Río(s) principal(es):

Río Alto Ribeirão

Microcuenca(s):

Tapera

Forma del manglar:

$\square$ Regular

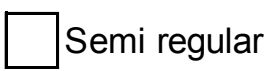

$\mathrm{X}$ Irregular

Conexión del manglar con la vegetación próxima:

$\begin{array}{ll}\square \text { Parcialmente conectado } & \square \text { Muy poco conectado } \\ \mathrm{X} \text { Poco conectado } & \square \text { Aislado }\end{array}$

\section{FACTORES HUMANOS}

Fragmentación del manglar:

$\mathrm{X}$ Fragmentado No fragmentado

Número de fragmentación del manglar:

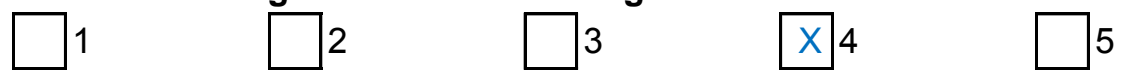

Elemento(s) de fragmentación del manglar:
$\square$ Agricultura/ganadería
$\square$ Acuicultura
X Urbanización
$\mathrm{X}$ Carreteras

Elemento(s) de fragmentación del manglar con la vegetación próxima:

\begin{tabular}{ll}
\hline $\mathrm{X}$ Agricultura/ganadería & $\square$ Acuicultura \\
\hline $\mathrm{X}$ Urbanización & $\square$ Carreteras
\end{tabular}

Uso del suelo predominante:

$\mathrm{X}$ Agricultura/ganadería $\square$ Urbanización $\square$ Ambos

Figura 6.43: Ficha de caracterización del manglar de Tapera. Fuente: Elaboración propia. 


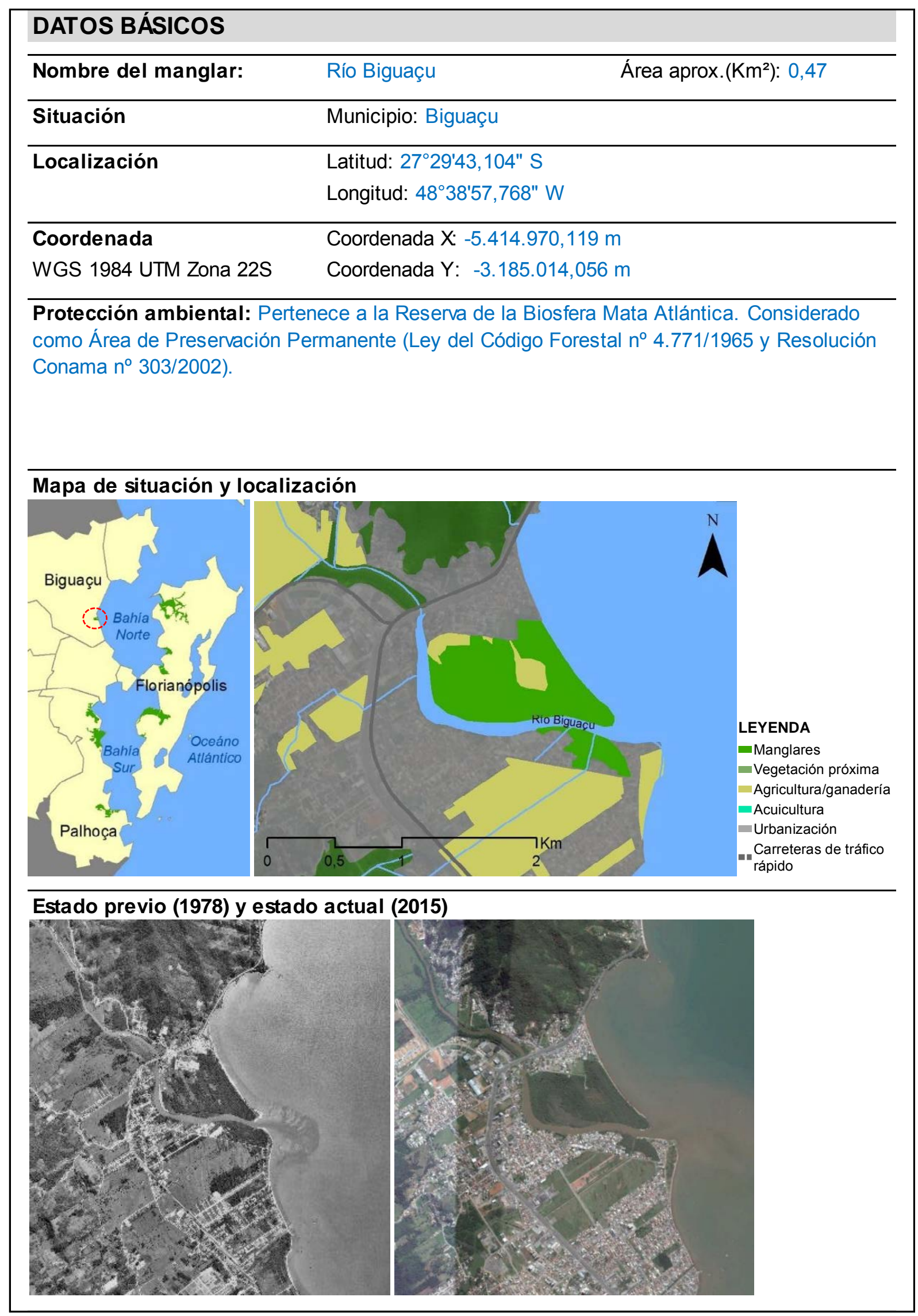




\section{CARACTERIZACIÓN ESPACIAL DEL PAISAJE DE MANGLAR}

\section{FACTORES NATURALES}

Río(s) principal(es):

Río Biguaçu

Microcuenca(s):

\section{Córrego da Saudade/Biguaçu}

Forma del manglar:

$\mathrm{X}$ Regular

$\square$ Semi regular

$\square$ Irregular

Conexión del manglar con la vegetación próxima:

$\begin{array}{ll}\square \text { Parcialmente conectado } & \square \text { Muy poco conectado } \\ \square \text { Poco conectado } & \mathrm{X} \text { Aislado }\end{array}$

\section{FACTORES HUMANOS}

Fragmentación del manglar:

$\square$ Fragmentado $\quad X$ No fragmentado

Número de fragmentación del manglar:

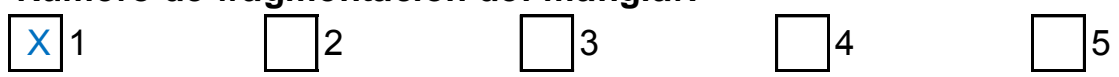

Elemento(s) de fragmentación del manglar:
$\square$ Agricultura/ganadería
$\square$ Acuicultura
$\square$ Urbanización
Carreteras

Elemento(s) de fragmentación del manglar con la vegetación próxima:

X Agricultura/ganadería

$\mathrm{X}$ Urbanización

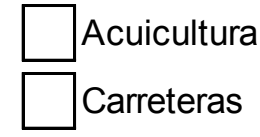

Uso del suelo predominante:
Agricultura/ganadería
X Urbanización
Ambos

Figura 6.44: Ficha de caracterización del manglar del Río Biguaçu. Fuente: Elaboración propia. 


\begin{tabular}{|c|c|}
\hline \multicolumn{2}{|l|}{ DATOS BÁSICOS } \\
\hline Nombre del manglar: & Área aprox. $\left(\mathrm{Km}^{2}\right): 2,95$ \\
\hline Situación & Municipio: Palhoça \\
\hline \multirow[t]{2}{*}{ Localización } & Latitud: $27^{\circ} 39^{\prime} 22,656^{\prime \prime} \mathrm{S}$ \\
\hline & Longitud: $48^{\circ} 39^{\prime} 41,946 " \mathrm{~W}$ \\
\hline Coordenada & Coordenada X: $-5.416 .380,461 \mathrm{~m}$ \\
\hline WGS 1984 UTM Zona 22S & Coordenada Y: $-3.205 .583,422 \mathrm{~m}$ \\
\hline
\end{tabular}

Protección ambiental: Pertenece a la Reserva de la Biosfera Mata Atlántica. Considerado como Área de Preservación Permanente (Ley del Código Forestal n 4.771/1965 y Resolución Conama $n^{\circ}$ 303/2002).
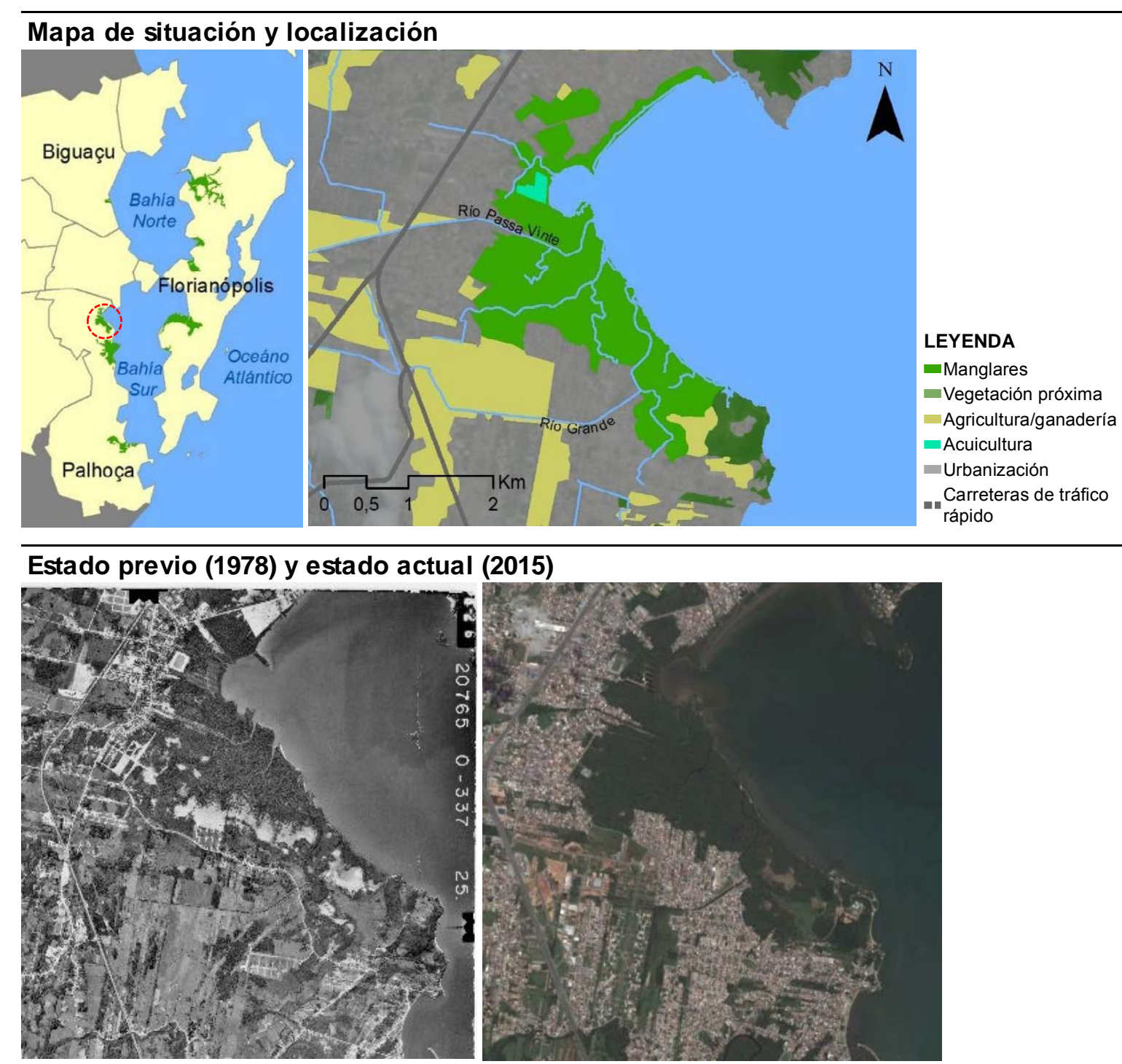


\section{CARACTERIZACIÓN ESPACIAL DEL PAISAJE DE MANGLAR}

\section{FACTORES NATURALES}

Río(s) principal(es):

Río Passa Viente

Microcuenca(s):

Río Maruim/Río Passa Viente y Río Grande

Forma del manglar:

$\square$ Regular

$\mathrm{X}$ Semi regular

$\square$ Irregular

Conexión del manglar con la vegetación próxima:

$\begin{array}{ll}\square \text { Parcialmente conectado } & X \text { Muy poco conectado } \\ \square \text { Poco conectado } & \square \text { Aislado }\end{array}$

\section{FACTORES HUMANOS}

Fragmentación del manglar:

$\mathrm{X}$ Fragmentado No fragmentado

Número de fragmentación del manglar:

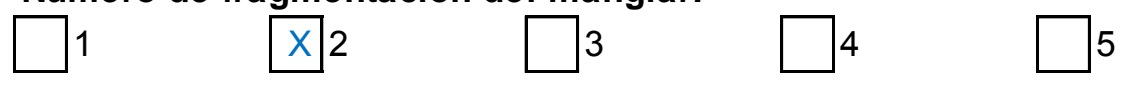

Elemento(s) de fragmentación del manglar:
$\square$ Agricultura/ganadería
$\square$ Acuicultura
X Urbanización
Carreteras

Elemento(s) de fragmentación del manglar con la vegetación próxima:

$\mathrm{X}$ Agricultura/ganadería

$\mathrm{X}$ Urbanización

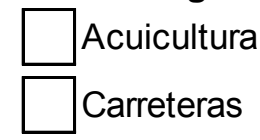

Uso del suelo predominante:
Agricultura/ganadería
X Urbanización Ambos

Figura 6.45: Ficha de caracterización del manglar de Palhoça. Fuente: Elaboración propia. 


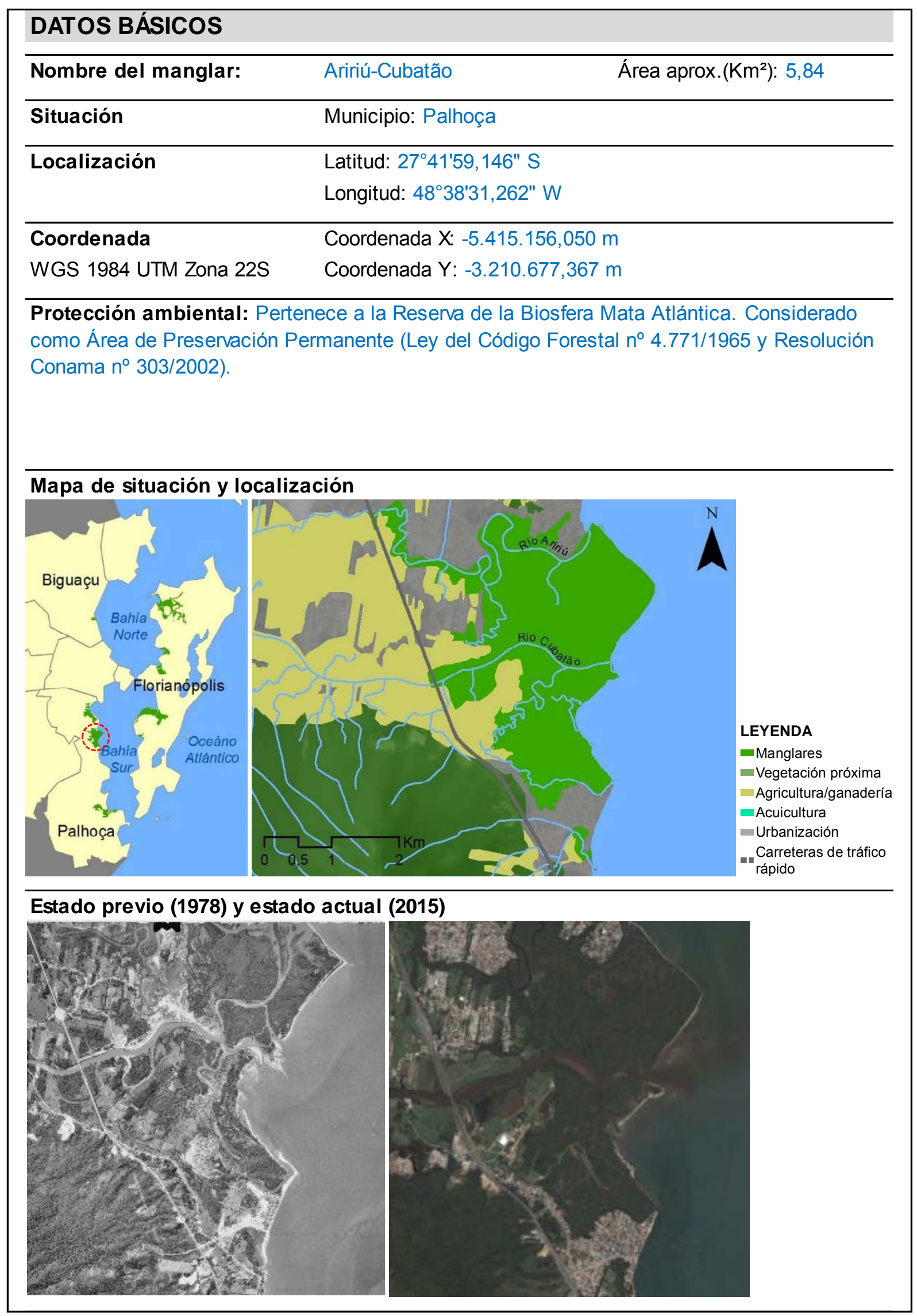




\section{CARACTERIZACIÓN ESPACIAL DEL PAISAJE DE MANGLAR}

\section{FACTORES NATURALES}

Río(s) principal(es):

Río Aririú y Río Cubatão

Microcuenca(s):

Río Aririú/Guarda/Ribeirão Cachoeira do Amarinho y Ribeirão Cachoeira do Retiro

Forma del manglar:

$\square$ Regular

$X$ Semi regular

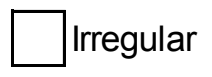

Conexión del manglar con la vegetación próxima:

$\begin{array}{ll}\square \text { Parcialmente conectado } & \square \text { Muy poco conectado } \\ \square \text { Poco conectado } & \mathrm{X} \text { Aislado }\end{array}$

\section{FACTORES HUMANOS}

Fragmentación del manglar:

$\mathrm{X}$ Fragmentado $\square$ No fragmentado

Número de fragmentación del manglar:

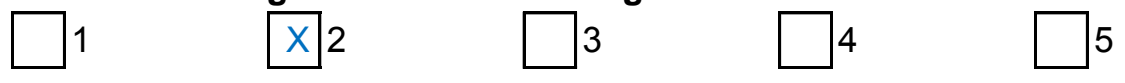

Elemento(s) de fragmentación del manglar:
$\square$ Agricultura/ganadería
$\square$ Acuicultura
X Urbanización
Carreteras

Elemento(s) de fragmentación del manglar con la vegetación próxima:

$\mathrm{X}$ Agricultura/ganadería

$\mathrm{X}$ Urbanización

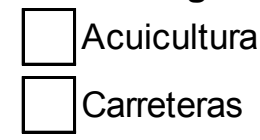

Uso del suelo predominante:

Agricultura/ganadería $\square$ Urbanización $\quad \mathrm{X}$ Ambos

Figura 6.46: Ficha de caracterización del manglar de Aririú-Cubatão. Fuente: Elaboración propia. 


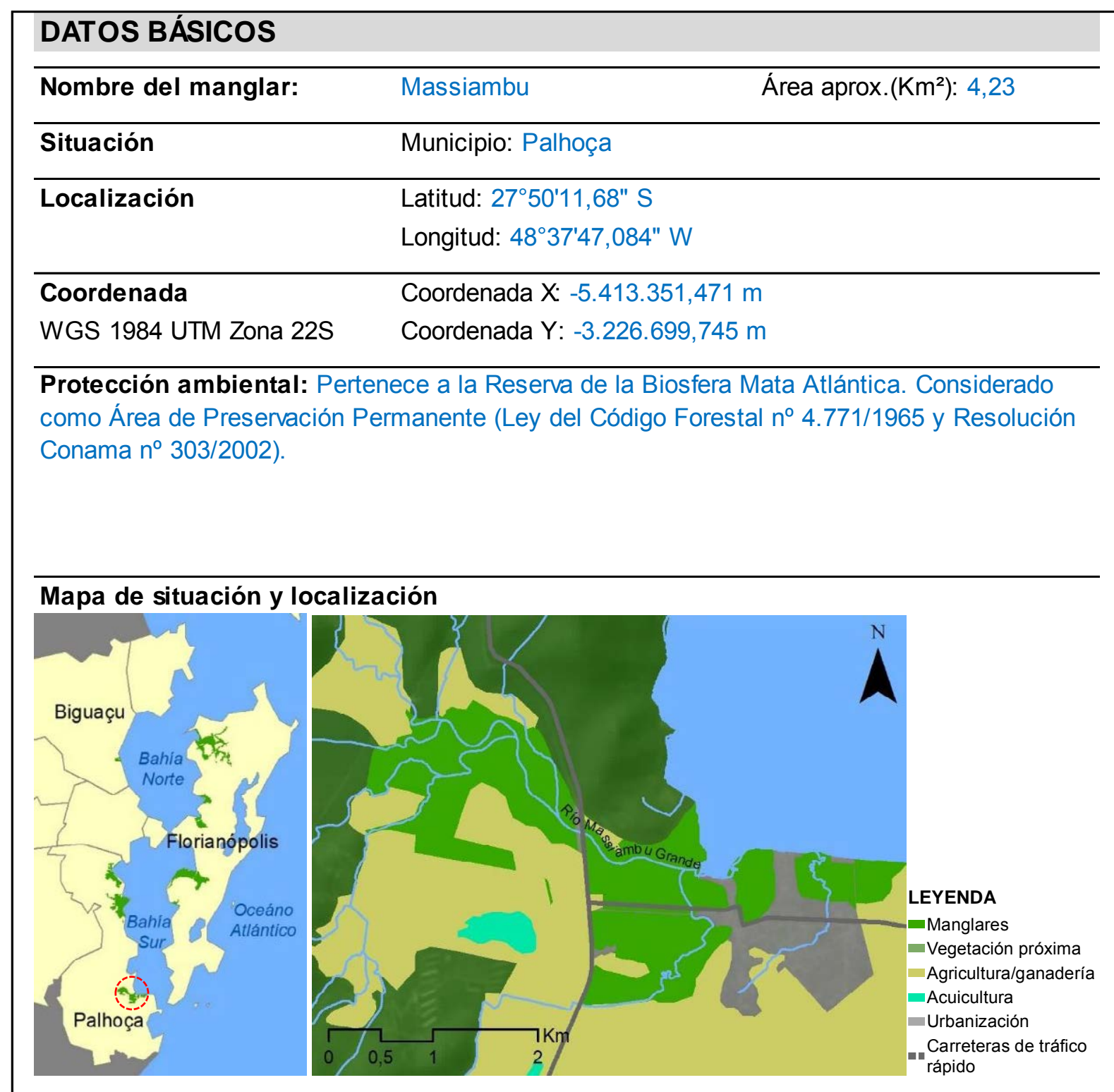

Estado previo (1978) y estado actual (2015)

Sin datos

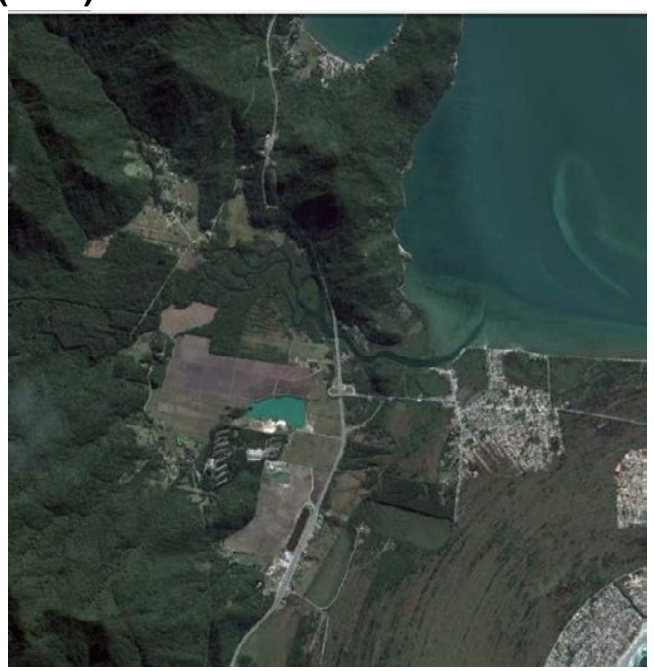




\section{CARACTERIZACIÓN ESPACIAL DEL PAISAJE DE MANGLAR}

\section{FACTORES NATURALES}

Río(s) principal(es):

Río Massiambu Grande

Microcuenca(s):

Río Cambirela y Río do Veríssimo/Río Massiambu Grande/Río Capivari

Forma del manglar:

$\square$ Regular

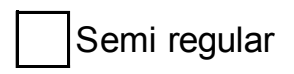

$\mathrm{X}$ Irregular

Conexión del manglar con la vegetación próxima:

$\begin{array}{ll}\square \text { Parcialmente conectado } & \square \text { Muy poco conectado } \\ \mathrm{X} \text { Poco conectado } & \square \text { Aislado }\end{array}$

\section{FACTORES HUMANOS}

Fragmentación del manglar:

$\mathrm{X}$ Fragmentado

$\square$ No fragmentado

Número de fragmentación del manglar:

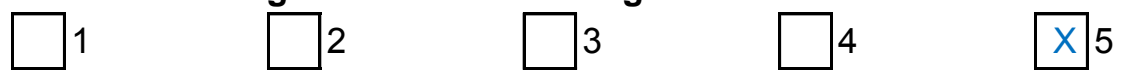

Elemento(s) de fragmentación del manglar:
$\square$ Agricultura/ganadería
$\square$ Acuicultura
X Urbanización
$\mathrm{X}$ Carreteras

Elemento(s) de fragmentación del manglar con la vegetación próxima:

$\mathrm{X}$ Agricultura/ganadería

$\mathrm{X}$ Urbanización

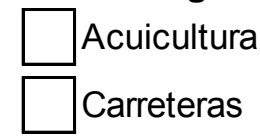

Uso del suelo predominante:

$\mathrm{X}$ Agricultura/ganadería $\square$ Urbanización $\square$ Ambos

Figura 6.47: Ficha de caracterización del manglar de Massiambu. Fuente: Elaboración propia. 
De acuerdo con los análisis de las fichas de caracterización, se verificó que el manglar del Río Ratones, ubicado al Norte del Municipio de Florianópolis, está considerado como el manglar de forma más irregular de la Región Metropolitana de Florianópolis. Se identificó un número total de tres fragmentos de manglares que están parcialmente conectados con la vegetación próxima. En cuanto al uso del suelo en este paisaje, se observó la predominancia de agricultura/ganadería.

Así como el manglar del Río Ratones, los manglares de Tapera y de Massiambu, ubicados al Sur del Municipio de Florianópolis, poseen también formas irregulares y están bastante fragmentados, con un total de cuatro y cinco fragmentos, respectivamente. En estas zonas hay un predominio del uso de agricultura/ganadería y poca conexión del manglar con la vegetación próxima.

Los manglares del Río Tavares (Municipio de Florianópolis), de Palhoça (Municipio de Palhoça) y de Aririú-Cubatão (Municipio de Palhoça) tienen en común la forma semi regular y la fragmentación en dos partes. Se observaron los manglares muy poco conectados con la vegetación próxima en el Río Tavares y Palhoça, y aislado en Aririú-Cubatão. El uso predominante del suelo en el paisaje de manglar de Palhoça es urbano, mientras que en los paisajes del Río Tavares y de Aririú-Cubatão, además del uso urbano también hay áreas semejantes de agricultura/ganadería.

Los tres manglares considerados los más urbanizados de la Región Metropolitana son los de Saco Grande y de Itacorubi (ubicados en el Municipio de Florianópolis) y el del Río Biguaçu (Municipio de Biguaçu). Estos manglares presentan formas más regulares y están completamente aislados de la vegetación próxima. Mientras que los manglares de Saco Grande y del Río Biguaçu presentan una única mancha, el de Itacorubi está fragmentado en dos partes.

De esta forma, por lo tanto, se observó que cada paisaje de manglar prevalece en diferentes formas, número de fragmentaciones y elementos antrópicos, posibilitando la identificación de los patrones de uso del suelo para cada situación y la existencia o no de una conectividad ecológica, según muestra la Tabla 6.6. 


\begin{tabular}{|c|c|c|c|c|c|c|c|}
\hline Manglares & Municipios & FM & NFM & TC & EFM & EFMV & USP \\
\hline 1. Rio Ratones & Florianópolis & Irregular & 3 & $\begin{array}{l}\text { Parcialmente } \\
\text { conectado }\end{array}$ & Carreteras & $\begin{array}{c}\text { Agricultura/ganadería y } \\
\text { urbanización }\end{array}$ & Agricultura/ganadería \\
\hline 2. Saco Grande & Florianópolis & Regular & 1 & Aislado & - & Urbanización & Urbanización \\
\hline 3. Itacorubi & Florianópolis & Regular & 2 & Aislado & Carreteras & Urbanización & Urbanización \\
\hline 4. Rio Tavares & Florianópolis & Semi regular & 2 & $\begin{array}{l}\text { Muy poco } \\
\text { conectado }\end{array}$ & Carreteras & $\begin{array}{c}\text { Agricultura/ganadería y } \\
\text { urbanización }\end{array}$ & Ambos \\
\hline 5. Tapera & Florianópolis & Irregular & 4 & Poco conectado & $\begin{array}{l}\text { Urbanización y } \\
\text { carreteras }\end{array}$ & $\begin{array}{c}\text { Agricultura/ganadería y } \\
\text { urbanización }\end{array}$ & Agricultura/ganadería \\
\hline 6. Rio Biguaçu & Biguaçu & Regular & 1 & Aislado & - & $\begin{array}{c}\text { Agricultura/ganadería y } \\
\text { urbanización }\end{array}$ & Urbanización \\
\hline 7. Palhoça & Palhoça & Semi regular & 2 & $\begin{array}{l}\text { Muy poco } \\
\text { conectado }\end{array}$ & Urbanización & $\begin{array}{c}\text { Agricultura/ganadería y } \\
\text { urbanización }\end{array}$ & Urbanización \\
\hline 8. Aririú-Cubatão & Palhoça & Semi regular & 2 & Aislado & Urbanización & $\begin{array}{c}\text { Agricultura/ganadería y } \\
\text { urbanización }\end{array}$ & Ambos \\
\hline 9. Massiambu & Palhoça & Irregular & 5 & Poco conectado & $\begin{array}{l}\text { Urbanización y } \\
\text { carreteras }\end{array}$ & $\begin{array}{c}\text { Agricultura/ganadería y } \\
\text { urbanización }\end{array}$ & Agricultura/ganadería \\
\hline
\end{tabular}

Leyenda: FM: forma de los manglares, NFM: número de fragmentación de los manglares, TC: tipo de conexión de los manglares con la vegetación próxima, EFM: elementos de fragmentación de los manglares, EFMV: elementos de fragmentación de los manglares con la vegetación próxima y USP: uso del suelo predominante.

Tabla 6.6: Caracterización de los paisajes de manglares. Fuente: Elaboración propia. 
Conforme la caracterización, se puede observar el impacto ambiental que ha tenido lugar a lo largo del tiempo. En el aspecto general, hay una discontinuidad de los espacios naturales debido a la perdida y fragmentación de los manglares, generado por el uso del suelo principalmente a través de la agricultura/ganadería, la urbanización y las carreteras.

Se verificó que los paisajes de manglares se encuentran en diferentes estados de degradación ambiental. De esta forma se los dividió en tres categorías diferenciadas de impacto: los menos afectados, los afectados y los más afectados por la ocupación humana (Tabla 6.7).

\begin{tabular}{|c|c|c|c|c|c|}
\hline Categorías & Manglares & FM & NFM & TC & USP \\
\hline \multirow{3}{*}{ Menos afectados } & Río Ratones & \multirow{3}{*}{ Irregular } & \multirow{3}{*}{$\geq 3$} & \multirow{3}{*}{$\begin{array}{l}\text { Parcialmente } \\
\text { conectado y poco } \\
\text { conectado }\end{array}$} & \multirow{3}{*}{ Agricultura/ganadería } \\
\hline & Massiambu & & & & \\
\hline & Tapera & & & & \\
\hline \multirow{3}{*}{ Afectados } & Río Tavares & \multirow{3}{*}{ Semi regular } & \multirow{3}{*}{2} & \multirow{3}{*}{$\begin{array}{l}\text { Muy poco } \\
\text { conectado y } \\
\text { aislado }\end{array}$} & \multirow{3}{*}{ Urbanización y ambos } \\
\hline & Palhoça & & & & \\
\hline & Aririu-Cubatão & & & & \\
\hline \multirow{3}{*}{ Más afectados } & Biguaçu & \multirow{3}{*}{ Regular } & \multirow{3}{*}{$\leq 2$} & \multirow{3}{*}{ Aislado } & \multirow{3}{*}{ Urbanización } \\
\hline & Saco Grande & & & & \\
\hline & Itacorubi & & & & \\
\hline
\end{tabular}

Tabla 6.7: Categorización de impacto de los paisajes de manglares. Fuente: Elaboración propia.

El paisaje de manglar menos afectado es el del Río Ratones, seguido por los paisajes de Massiambu y de Tapera, pues se verifica como los mejores conectados con la vegetación próxima. Asimismo tienen formas más irregulares y un mayor número de fragmentación. En estos paisajes hay predominio de la agricultura/ganadería en comparación con la urbanización. Tal situación se confirma por el vector de la expansión urbana, que viene ocupando inicialmente las zonas más céntricas de los municipios de la Región Metropolitana en dirección a los sitios más al Norte y Sur.

El peor caso, el más afectado, debido a un mayor aislamiento de los manglares por la presencia de la urbanización, corresponde con el paisaje de manglar de Itacorubi, seguido por el de Saco Grande, al estar ubicados en la zona central del Municipio de Florianópolis, razón por la que están más urbanizados. Estos manglares también tienen en común su forma regular y poca fragmentación. 
Todos los manglares de la Región Metropolitana de Florianópolis pertenecen a la Reserva de la Biosfera Mata Atlántica. La extensión de ellos, así como sus áreas adyacentes con influencia de las mareas y/o vegetación característica de transición entre los manglares y los suelos secos, están consideradas como Área de Preservación Permanente. Se delimitan en los Planes Directores de los municipios, protegidas por el Código Forestal (Ley $\mathrm{n}^{\circ}$ $12.651 / 2012)^{62}$, que establece las normas generales relativas a la protección de la vegetación; y reglamentadas por el Consejo Nacional del Medio Ambiente (Conama) (Resolución $n^{\circ}$ 303/2002 $)^{63}$, que trata sobre los parámetros, definiciones y límites de Área de Preservación Permanente. Algunos de los manglares del territorio (Río Ratones, Saco Grande, Itacorubi y Río Tavares) pertenecen también al Sistema Nacional de Unidades de Conservación de la Naturaleza (SNUC) (Ley $n^{\circ}$ 9.985/2000)64, que establece los criterios y normas para la creación, implementación y gestión de estas áreas protegidas.

Sin embargo, la degradación proviene de una falta de fiscalización ambiental, según se ha relatado en la Sección 6.3.2 de este documento sobre el histórico de la ocupación del suelo en la Región Metropolitana de Florianópolis. Además, hay una inexistencia de estrategias eficientes para el mantenimiento de la conectividad ecológica entre los manglares y la vegetación de entorno próximo, dificultando el flujo de genes de la fauna y flora e impidiendo proporcionar los servicios ecosistémicos generados por los manglares.

\subsection{PERCEPCIÓN DE LA POBLACIÓN}

Este subcapítulo tiene como objetivo verificar el valor cultural de los paisajes de manglares de la Región Metropolitana de Florianópolis, a través del análisis de la percepción de la población sobre el dicho espacio. Los temas estudiados están relacionados con el grado de conocimiento de la población sobre los componentes bióticos y abióticos, los servicios ecosistémicos, los impactos ambientales generados y los cambios para el futuro. Se hizo a través de una encuesta con 82 personas, a partir de un cuestionario de selección múltiple (Figura 6.48).

\footnotetext{
62 Brasil (2012). Lei do Código Florestal n 12.651. Dispõe sobre a proteção da vegetação nativa.

63 Brasil (2002). Conselho Nacional do Meio Ambiente. Ministério do Meio Ambiente (Conama), Resolução $n^{\circ}$ 303/2002. Dispõe sobre parâmetros, defi nições e limites de Áreas de Preservação Permanente.

${ }^{64}$ Brasil (2000). Lei $n^{\circ}$ 9.985. institui o Sistema Nacional de Unidades de Conservação da Natureza e dá outras providências.
} 


\begin{tabular}{|c|}
\hline $\begin{array}{c}\text { Encuesta sobre la percepción de los manglares de la } \\
\text { Región Metropolitana de Florianópolis }\end{array}$ \\
\hline
\end{tabular}

Datos del encuestado

\begin{tabular}{|l|}
\hline Edad: Sexo: $($ ) femenino ( ) masculino \\
\hline Estudio: ( ) sin estudio ( ) básico ( ) secundario ( ) superior \\
\hline Nivel de implicación: ( ) residente nativo ( ) residente temporal ( ) visitante \\
\hline
\end{tabular}

Cuestionario

1) ¿Que manglares conoces de la Región Metropolitana de Florianópolis?
( ) Río Ratones
( ) Saco Grande
( ) Itacorubi
( ) Río Tavares
( ) Tapera
( ) Massiambu
( ) Aririú-Cubatão
( ) Palhoça
( ) Río Biguaçu
( ) Conozco uno más, pero no sé sus nombres

2) ¿Qué relaciones tienes con este paisaje? (Seleccionar una o más opciones).
( ) Zona de recreación
( ) Zona de pesca
( ) Zona de paso habitual
( ) Zona de paso ocasional

3) Identifique los elementos siguientes de acuerdo con su percepción sobre este paisaje.

\begin{tabular}{|l|l|}
\hline a) Densidad de vegetación: ( ) Baja ( ) Mediana ( ) Alta \\
\hline b) Diversidad de fauna: ( ) Baja ( ) Mediana ( ) Alta \\
\hline c) Zona de transición entre la tierra y el mar: ( ) Baja ( ) Mediana ( ) Alta \\
\hline d) Ríos: ( ) Baja ( ) Mediana ( ) Alta \\
\hline e) Zona pantanosa: ( ) Baja ( ) Mediana ( ) Alta \\
\hline f) Pesca: ( ) Baja ( ) Mediana ( ) Alta \\
\hline g) Zona de ocio: ( ) Baja ( ) Mediana ( ) Alta \\
\hline h) Vegetación densa: ( ) Baja ( ) Mediana ( )Alta \\
\hline
\end{tabular}

4) ¿Qué valoración estética darías a este paisaje?
( ) Baja
( ) Mediana
( ) Alta

5) ¿Qué valoración ecológica otorgarías a este paisaje?
( ) Baja
( ) Mediana
( ) Alta

6) ¿Crees que este paisaje se ha degradado?

( ) No se ha degradado ( ) Se ha degradado

7) Si crees que se ha degradado, valora el impacto que han tenido las siguientes actividades humanas:

\begin{tabular}{|l|l|}
\hline a) Edificación: ( ) Baja ( ) Mediana ( ) Alta \\
\hline b) Agricultura/ganadería: ( ) Baja ( ) Mediana ( )Alta \\
\hline c) Depósito de basura: ( ) Baja ( ) Mediana ( )Alta \\
\hline d) Devastación: ( ) Baja ( ) Mediana ( ) Alta \\
\hline e) Contaminación de residuos residenciales e industriales: ( ) Baja ( ) Mediana ( ) Alta \\
\hline f) Vías de carreteras: ( ) Baja ( ) Mediana ( )Alta \\
\hline g) Acuicultura: ( ) Baja ( ) Mediana ( )Alta
\end{tabular}

8) De cara al futuro de estos paisajes, ¿qué modificarías?

\begin{tabular}{|l|l|}
\hline a) Edificación: ( )Aumentarías ( ) No cambiarías ( ) Disminuirías \\
\hline b) Agricultura/ganadería: ( ) Aumentarías ( ) No cambiarías ( ) Disminuirías \\
\hline c) Contaminación (basura/residuos): ( ) Aumentarías ( ) No cambiarías ( ) Disminuirías \\
\hline d) Vegetación: ( ) Aumentarías ( ) No cambiarías ( ) Disminuirías \\
\hline e) Vías de carreteras: ( )Aumentarías ( ) No cambiarías ( ) Disminuirías \\
\hline f) Acuicultura: ( ) Aumentarías ( ) No cambiarías ( ) Disminuirías \\
\hline g) Pesca: ( ) Aumentarías ( ) No cambiarías ( ) Disminuirías \\
\hline h) Recreación: ( ) Aumentarías ( ) No cambiarías ( ) Disminuirías \\
\hline
\end{tabular}

Figura 6.48: Encuesta. Fuente: Elaboración propia. 
En cuanto a los datos de los encuestados, se dividieron en relación a la edad: 2,44\% (hasta 20 años), $51,22 \%$ (entre 21 y 40 años), 36,59\% (entre 41 y 60) y 3,54\% (más de 61); sexo: 30,50\% (femenino), 69,50\% (masculino); estudios: 80,50\% (superior), 13,4\% (secundario), 6,10\% (primario); y niveles de implicación: 73,20\% (residente nativo), 26,80\% (residente temporal y visitante).

El cuestionario consta de tres partes distintas, en los que se relacionan con los factores naturales y humanos que influyen en los manglares de la Región Metropolitana de Florianópolis: 1. Identificación y relación personal: identificación de los manglares de conocimiento de la población y la relación personal con estos paisajes; 2. Factores naturales: percepción sobre los componentes bióticos y abióticos y sus servicios ecosistémicos; 3 . Factores humanos: percepción sobre los impactos ambientales producidos por los elementos antrópicos en el paisaje y cambios para el futuro.

Los criterios de evaluación son definidos por el porcentaje de los encuestados entre los dos niveles de implicación: los residentes nativos y los residentes temporales y visitantes, debido a una percepción diferenciada entre ambos. Para medir la percepción de los encuestados, están divididas entre percepción baja, mediana y alta para los factores naturales y los factores humanos, en cuanto a los impactos ambientales; y aumentaría, no cambiaría y disminuiría para los cambios futuros. Una vez realizadas las encuestas se extrajeron los siguientes datos:

1. Identificación y relación personal:

En relación a la identificación de los manglares, se verifica tanto para los residentes nativos, como para los residentes temporales y visitantes, un mayor conocimiento del manglar de Itacorubi (más de 65\%). Los manglares están relacionados, en mayor grado, como zona de paso habitual y ocasional (más de $40 \%$ para cada) para los dos niveles de implicación (Tabla $6.8)$. 


\begin{tabular}{|c|c|c|c|}
\hline & Manglares & Residente nativo (\%) & Res. temporal y visitante (\%) \\
\hline \multirow{10}{*}{ 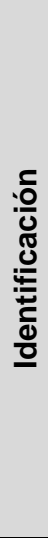 } & Rio Ratones & 28,33 & 13,64 \\
\hline & Saco Grande & 43,33 & 40,91 \\
\hline & Itacorubi & 81,67 & 68,18 \\
\hline & Rio Tavares & 40,00 & 36,36 \\
\hline & Tapera & 33,33 & 9,09 \\
\hline & Massiambu & 16,67 & 9,09 \\
\hline & Aririú-Cubatão & 5,00 & 4,55 \\
\hline & Palhoça & 11,67 & 18,18 \\
\hline & Rio Biguaçu & 5,00 & 4,55 \\
\hline & No sabe el nombre (conoce un o más) & 16,67 & 22,73 \\
\hline \multirow{4}{*}{$\begin{array}{l}\frac{}{0} \\
\frac{\mathbb{0}}{0} \\
\frac{\pi}{\mathbb{d}}\end{array}$} & Zona de paso habitual & 46,67 & 45,45 \\
\hline & Zona de paso ocasional & 41,67 & 45,45 \\
\hline & Zona de ocio & 5,00 & 9,09 \\
\hline & Uso para pesca & 6,67 & 0,00 \\
\hline
\end{tabular}

Tabla 6.8: Identificación y relación personal con los manglares. Fuente: Elaboración propia.

\section{Factores naturales:}

De acuerdo con los componentes bióticos y abióticos de los manglares, se verifica, en general, una percepción entre baja y mediana para la mayoría de los encuestados, según la Tabla 8. Para los dos niveles de implicación, la vegetación densa y la zona pantanosa presentan una percepción mediana y la fauna una percepción baja. La zona de transición entre la tierra y el mar presenta una percepción mediana para los residentes nativos y baja para los residentes temporales y visitantes. Los ríos apuntan como una baja percepción para los residentes nativos y entre baja y mediana para los residentes temporales y visitantes. En cuanto a los servicios ecosistémicos, para los dos niveles de implicación, presentan una percepción baja en relación a la pesca y la zona de ocio, y alta para la belleza estética y la importancia ecológica (Tabla 6.9). 


\begin{tabular}{|c|c|c|c|c|c|}
\hline & Manglares & Nivel de implicación & Baja (\%) & Mediana (\%) & Alta (\%) \\
\hline \multirow{10}{*}{ 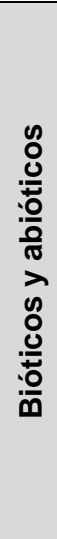 } & \multirow{2}{*}{ Vegetación densa } & Residente nativo & 24,14 & 58,62 & 17,24 \\
\hline & & Res. temporal y visitante & 27,27 & 54,55 & 18,18 \\
\hline & \multirow{2}{*}{ Diversidad de fauna } & Residente nativo & 74,14 & 20,69 & 5,17 \\
\hline & & Res. temporal y visitante & 72,73 & 27,27 & 0,00 \\
\hline & \multirow{2}{*}{$\begin{array}{l}\text { Zona de transición entre } \\
\text { la tierra y el mar }\end{array}$} & Residente nativo & 37,50 & 46,43 & 16,07 \\
\hline & & Res. temporal y visitante & 63,64 & 27,27 & 9,09 \\
\hline & \multirow{2}{*}{ Ríos } & Residente nativo & 51,72 & 37,93 & 10,34 \\
\hline & & Res. temporal y visitante & 45,45 & 45,45 & 9,09 \\
\hline & \multirow{2}{*}{ Zona pantanosa } & Residente nativo & 31,58 & 42,11 & 26,32 \\
\hline & & Res. temporal y visitante & 18,18 & 54,55 & 27,27 \\
\hline \multirow{8}{*}{$\begin{array}{l}\frac{0}{0} \\
\frac{0}{2} \\
\frac{2}{\infty}\end{array}$} & \multirow{2}{*}{ Pesca } & Residente nativo & 51,72 & 39,66 & 8,62 \\
\hline & & Res. temporal y visitante & 77,27 & 18,18 & 4,55 \\
\hline & \multirow{2}{*}{ Zona de ocio } & Residente nativo & 84,21 & 14,04 & 1,75 \\
\hline & & Res. temporal y visitante & 77,27 & 22,73 & 0,00 \\
\hline & \multirow{2}{*}{ Belleza estética } & Residente nativo & 13,56 & 18,64 & 67,80 \\
\hline & & Res. temporal y visitante & 13,64 & 13,64 & 72,73 \\
\hline & \multirow{2}{*}{ Importancia ecológica } & Residente nativo & 1,67 & 10,00 & 88,33 \\
\hline & & Res. temporal y visitante & 4,55 & 4,55 & 90,91 \\
\hline
\end{tabular}

Tabla 6.9: Percepción sobre los componentes bióticos y abióticos de los manglares y sus servicios ecosistémicos, identificados en amarillo los porcentajes más elevados. Fuente: Elaboración propia.

\section{Factores humanos:}

La población identifica que hay fuertes impactos ambientales de los manglares producidos por los elementos antrópicos, de acuerdo con la Tabla 6.10. Se verifica como una percepción alta, para los dos niveles de implicación, los impactos generados por la edificación, la devastación, la contaminación de residuos residenciales e industriales y las vías de carreteras; y baja en relación a la acuicultura. En cuanto a la agricultura y/o ganadería, se consideran como percepción baja para los residentes nativos y entre baja y mediana para los residentes temporales y visitantes. El depósito de basura se presenta como una percepción entre mediana y alta para los residentes nativos y alta para los residentes temporales y visitantes. 


\begin{tabular}{|l|l|c|c|c|}
\hline \multicolumn{1}{|c|}{ Impactos ambientales } & \multicolumn{1}{|c|}{ Nivel de implicación } & Baja (\%) & Mediana (\%) & Alta (\%) \\
\hline \multirow{2}{*}{ Edificación } & Residente nativo & 3,33 & 26,67 & 66,67 \\
\cline { 2 - 5 } & Res. temporal y visitante & 0,00 & 22,73 & 72,73 \\
\hline \multirow{2}{*}{ Agricultura y/o ganadería } & Residente nativo & 46,67 & 36,67 & 10,00 \\
\cline { 2 - 5 } & Res. temporal y visitante & 40,91 & 40,91 & 13,64 \\
\hline \multirow{2}{*}{ Depósito de basura } & Residente nativo & 16,67 & 38,33 & 38,33 \\
\cline { 2 - 5 } & Res. temporal y visitante & 9,09 & 27,27 & 59,09 \\
\hline \multirow{2}{*}{ Devastación } & Residente nativo & 8,33 & 25,00 & 63,33 \\
\cline { 2 - 5 } & Res. temporal y visitante & 0,00 & 22,73 & 72,73 \\
\hline \multirow{2}{*}{$\begin{array}{l}\text { Contaminación de residuos } \\
\text { residenciales e industriales }\end{array}$} & Residente nativo & 5,00 & 15,00 & 71,67 \\
\cline { 2 - 5 } & Res. temporal y visitante & 0,00 & 4,55 & 90,91 \\
\hline \multirow{2}{*}{ Vías de carreteras } & Residente nativo & 10,00 & 31,67 & 53,33 \\
\cline { 2 - 5 } & Res. temporal y visitante & 4,55 & 31,82 & 59,09 \\
\hline \multirow{2}{*}{ Acuicultura } & Residente nativo & 53,33 & 31,67 & 5,00 \\
\cline { 2 - 5 } & Res. temporal y visitante & 54,55 & 27,27 & 13,64 \\
\hline
\end{tabular}

Tabla 6.10: Percepción sobre los impactos ambientales en los manglares, identificados en amarillo los porcentajes más elevados. Fuente: Elaboración propia.

Según la percepción sobre los impactos ambientales, la población desearía en el futuro para los manglares la disminución de la edificación, la agricultura y/o ganadería, la contaminación de basura y residuos y las vías de carreteras; y el aumento de las áreas de vegetación y de recreación en los manglares. Respecto a la acuicultura, no cambiarían, según los residentes nativos, y aumentarían, según los residentes temporales y visitantes. En cuanto a la actividad de pesca, no cambiarían, de acuerdo con los residentes nativos, y entre no cambiarían y aumentarían, según los residentes temporales y visitantes (Tabla 6.11). 


\begin{tabular}{|l|l|c|c|c|}
\hline \multicolumn{1}{|c|}{$\begin{array}{c}\text { Cambios para el } \\
\text { futuro }\end{array}$} & \multicolumn{1}{|c|}{ Nivel de implicación } & Aumentaría (\%) & No cambiaría (\%) & Disminuiría (\%) \\
\hline \multirow{2}{*}{ Edificación } & Residente nativo & 8,33 & 13,33 & 78,33 \\
\cline { 2 - 5 } & Res. temporal y visitante & 13,64 & 18,18 & 68,18 \\
\hline \multirow{2}{*}{$\begin{array}{l}\text { Agricultura y/o } \\
\text { ganadería }\end{array}$} & Residente nativo & 8,33 & 23,33 & 61,67 \\
\cline { 2 - 5 } & Res. temporal y visitante & 9,09 & 13,64 & 77,27 \\
\hline \multirow{2}{*}{$\begin{array}{l}\text { Contaminación } \\
\text { basura/residuos) }\end{array}$} & Residente nativo & 5,00 & 5,00 & 88,33 \\
\cline { 2 - 5 } & Res. temporal y visitante & 4,55 & 4,55 & 90,91 \\
\hline \multirow{2}{*}{ Vegetación } & Residente nativo & 73,33 & 16,67 & 10,00 \\
\cline { 2 - 5 } & Res. temporal y visitante & 81,82 & 9,09 & 9,09 \\
\hline \multirow{2}{*}{ Vías de carreteras } & Residente nativo & 6,67 & 25,00 & 68,33 \\
\cline { 2 - 5 } & Res. temporal y visitante & 9,09 & 27,27 & 63,64 \\
\hline \multirow{2}{*}{ Acuicultura } & Residente nativo & 20,00 & 45,00 & 28,33 \\
\cline { 2 - 5 } & Res. temporal y visitante & 40,91 & 27,27 & 31,82 \\
\hline \multirow{2}{*}{ Pesca } & Residente nativo & 28,33 & 46,67 & 23,33 \\
\cline { 2 - 5 } & Res. temporal y visitante & 36,36 & 36,36 & 27,27 \\
\hline \multirow{2}{*}{ Recreación } & Residente nativo & 66,67 & 26,67 & 5,00 \\
\cline { 2 - 5 } & Res. temporal y visitante & 54,55 & 22,73 & 22,73 \\
\hline \multirow{2}{*}{ Ray }
\end{tabular}

Tabla 6.11: Cambios futuros en los manglares, identificados en amarillo los porcentajes más elevados. Fuente: Elaboración propia.

En este análisis hubo pocos encuestados en comparación con la población total de la Región Metropolitana de Florianópolis (1.014.105 hab.), abriendo la necesidad de profundizar este trabajo de investigación. Sin embargo, la utilización de 82 personas verificó una percepción distinta de la población en algunos puntos de este estudio, que refleja la vida cotidiana personal con las características del contexto histórico social.

De acuerdo con la caracterización espacial, los manglares con mayor impacto están relacionados con el área edificada en estos paisajes, tal como el de Itacorubi. Este hecho está en concordancia con la percepción de la población sobre los impactos ambientales generados, en gran parte por tener un mayor conocimiento de los manglares más urbanizados, donde el manglar de Itacorubi registró $78 \%$ de los encuestados.

Sin embargo, la relación de la población con estos manglares es puramente visual y casi nunca estancial, vinculada con áreas de paso habitual u ocasional. Debido a esa falta de integración de las estructuras poblacionales con el paisaje de los manglares, la riqueza de estos ecosistemas es prácticamente desconocida por los residentes nativos, residentes temporales y visitantes. Aunque la población tiene la percepción sobre la importancia ecológica y la belleza estética, no relaciona este ecosistema con la pesca y como zona de 
ocio.

Respecto a los cambios deseados por la población para el futuro de estos paisajes, existe una gran necesidad y demanda hacia su preservación, apoyada con medidas normativas, de gestión y ordenación de estos singulares paisajes. Dichas medidas ayudarán a paliar, contener y combatir la degradación e impactos ambientales producidos en las últimas décadas debido a las actividades humanas y los acelerados procesos de urbanización sobre estos territorios. 


\section{LA CONECTIVIDAD ECOLÓGICA EN LOS PAISAJES DE MANGLARES}

La importancia de la conectividad ecológica para la conservación de los ecosistemas ha dado lugar a la proliferación de estudios e investigaciones sobre los métodos para su medición, aportando un gran enfoque en esta área. Las investigaciones tienen como característica principal la relación entre la estructura espacial del hábitat y la supervivencia de las especies, donde los cambios por factores antropogénicos han dificultado este proceso en el paisaje.

En este aspecto, el concepto de la ecología del paisaje es fundamental para el desarrollo de los estudios en un paisaje. Esto depende de la configuración de las manchas y corredores en una matriz, teniendo múltiples formas de conexiones, tanto estructural (forma espacial del paisaje) como funcional (desplazamiento de las especies en el paisaje) (Burel y Baudry, 1999). Solamente con las dos dimensiones, estructural y funcional, producirá un valor significativo de la conectividad (Kindlmann y Burel, 2008). Sin embargo, según Kindlmann y Burel (2008), un mismo paisaje puede tener valores diversos de conectividad cuando se utilizan diferentes métricas, por lo que existe la necesidad de investigaciones para poder interrelacionarlas.

Por lo tanto, este capítulo se dedica a una evaluación de la conectividad ecológica en dos paisajes de manglares seleccionados de la Región Metropolitana de Florianópolis: el menos y el más afectado por la ocupación humana. Se desarrolló a través del análisis en el ámbito estructural y funcional, basada en los principios de la ecología del paisaje, utilizando un nuevo método para la combinación de variadas métricas. El estudio tiene como objetivo la identificación de los fragmentos de hábitat más críticos en ambos paisajes, relacionándolos con las figuras de protección ambiental vigentes para el mantenimiento de la conectividad ecológica con el propósito de lograr los servicios ecosistémicos de los manglares. El esquema de la Figura 7.1 representa el plan de estudio de la conectividad ecológica y tiene como base de investigación una especie amenazada de la fauna local, un reto para su conservación. 


\section{PAISAJE ESTRUCTURAL PAISAJE FUNCIONAL}

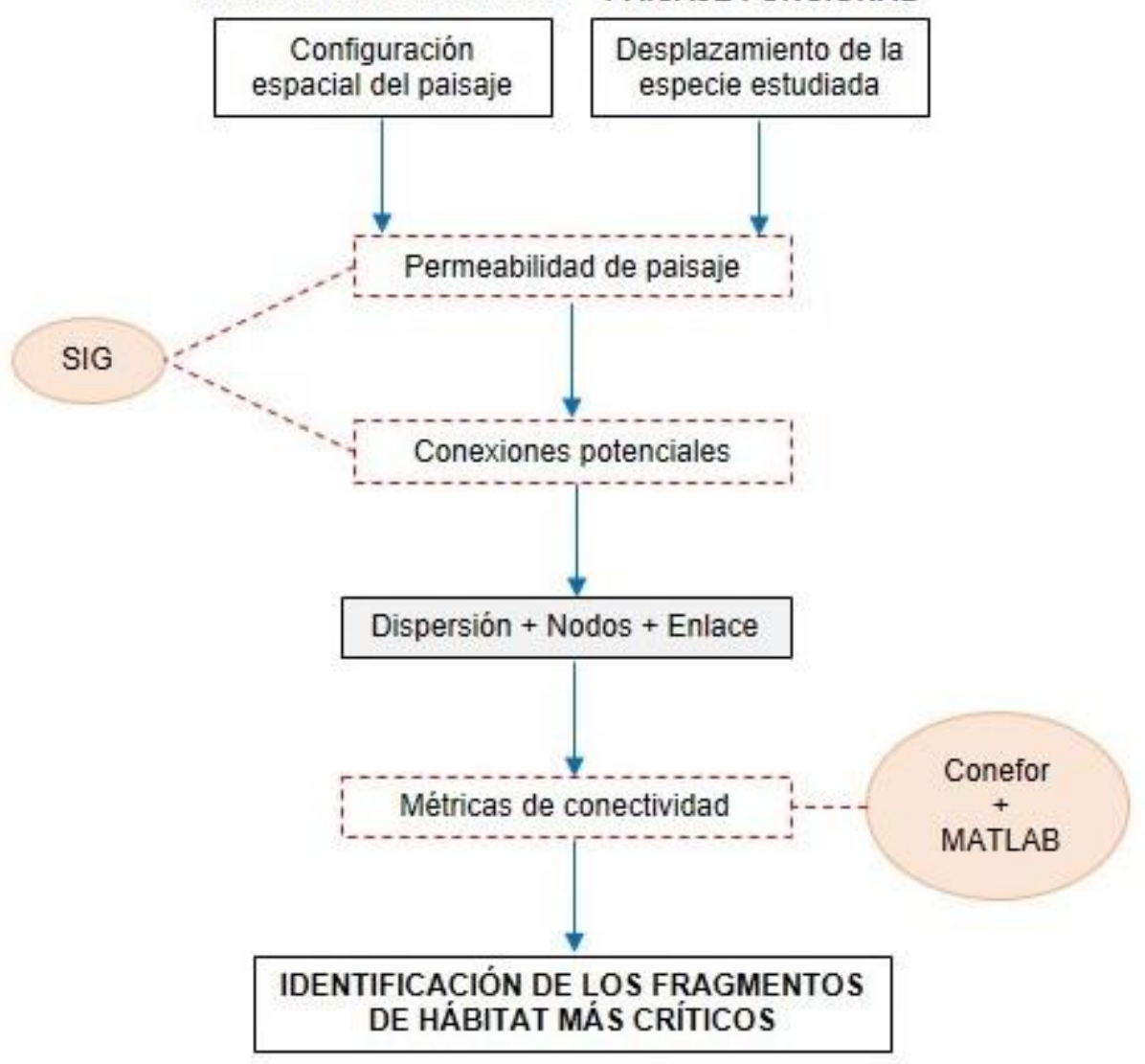

Figura 7.1: Esquema del análisis de la conectividad ecológica. Fuente: Elaboración propia.

Para su desarrollo, los subcapítulos subsecuentes están divididos en seis puntos, detallados a continuación:

7.1 SELECCIÓN DE LOS CASOS DE ESTUDIO: selección de los paisajes de manglares menos y más afectados de la Región Metropolitana de Florianópolis por la ocupación humana.

7.2 ESPECIE DE ESTUDIO: estudio de la nutria neotropical (Lontra longicaudis).

7.3 PERMEABILIDAD DE PAISAJE: análisis de la resistencia al movimiento de la especie estudiada en los paisajes. Para su elaboración, se utilizó el software SIG - Sistema de Información Geográfica ArcGis 10.3.

7.4 CONEXIONES POTENCIALES: identificación de las rutas de menor costo de la especie entre los fragmentos del hábitat. Para su elaboración, se utilizó el software SIG - Sistema de Información Geográfica ArcGis 10.3. 
7.5 MÉTRICAS DE CONECTIVIDAD: determinación de los valores de conectividad ecológica de cada fragmento de hábitat, a través de una combinación de variadas métricas de conectividad de la Teoría de Grafos. Estas métricas se apoyan en tres partes fundamentales: dispersión (distancia de desplazamiento de la especie), nodos (áreas de los fragmentos de hábitat utilizados por la especie estudiada) y enlaces (rutas de menor costo entre los fragmentos de hábitat). Para la elaboración de las métricas, se utilizaron los software Conefor Sensinode 2.6 y MATLAB R2016a.

7.6 DIAGNÓSTICO: identificación y análisis estructural y funcional de los fragmentos de hábitat más críticos en los paisajes, relacionándolos con las figuras de protección ambiental vigentes para el mantenimiento de la conectividad ecológica, a fin de establecer los servicios ecosistémicos de los manglares. 


\subsection{SELECCIÓN DE LOS CASOS DE ESTUDIO}

Este subcapítulo tiene el objetivo de elegir los paisajes de manglares menos y más afectados por la ocupación humana para el análisis de la conectividad ecológica. Se han seleccionado, entre los nueve los paisajes de manglares existentes en la Región Metropolitana de Florianópolis, los del Río Ratones y de Itacorubi. La selección está relacionada conforme a la caracterización espacial de los paisajes de manglares de la Región Metropolitana de Florianópolis, demostrada en la Sección 6.4.2 de este documento. Se verificaron diferentes formas, número de fragmentaciones, elementos antrópicos y predominancias del uso del suelo, con el objetivo de identificar distintos aspectos de conectividad ecológica en cada paisaje.

El desarrollo de los manglares de ambos paisajes se da por la protección de la Bahía Norte en la parte insular del Municipio de Florianópolis. Para este estudio, los dos paisajes se delimitaron en base a su microcuenca hidrográfica ${ }^{65}$, como unidad espacial de paisaje, con un área total de $116,24 \mathrm{~km}^{2}$ para Río Ratones y $28,27 \mathrm{~km}^{2}$ para Itacorubi. Se ubican respectivamente en las Latitudes $27^{\circ} 29^{\prime} 50,942^{\prime \prime}$ y $27^{\circ} 34^{\prime} 40,818^{\prime \prime}$ Sur y en las Longitudes $48^{\circ} 38^{\prime} 40,097^{\prime \prime}$ y $48^{\circ} 31^{\prime} 0,651 "$ Oeste (Figura 7.2).

65 Demostrado en la sección 6.2.1.6. 


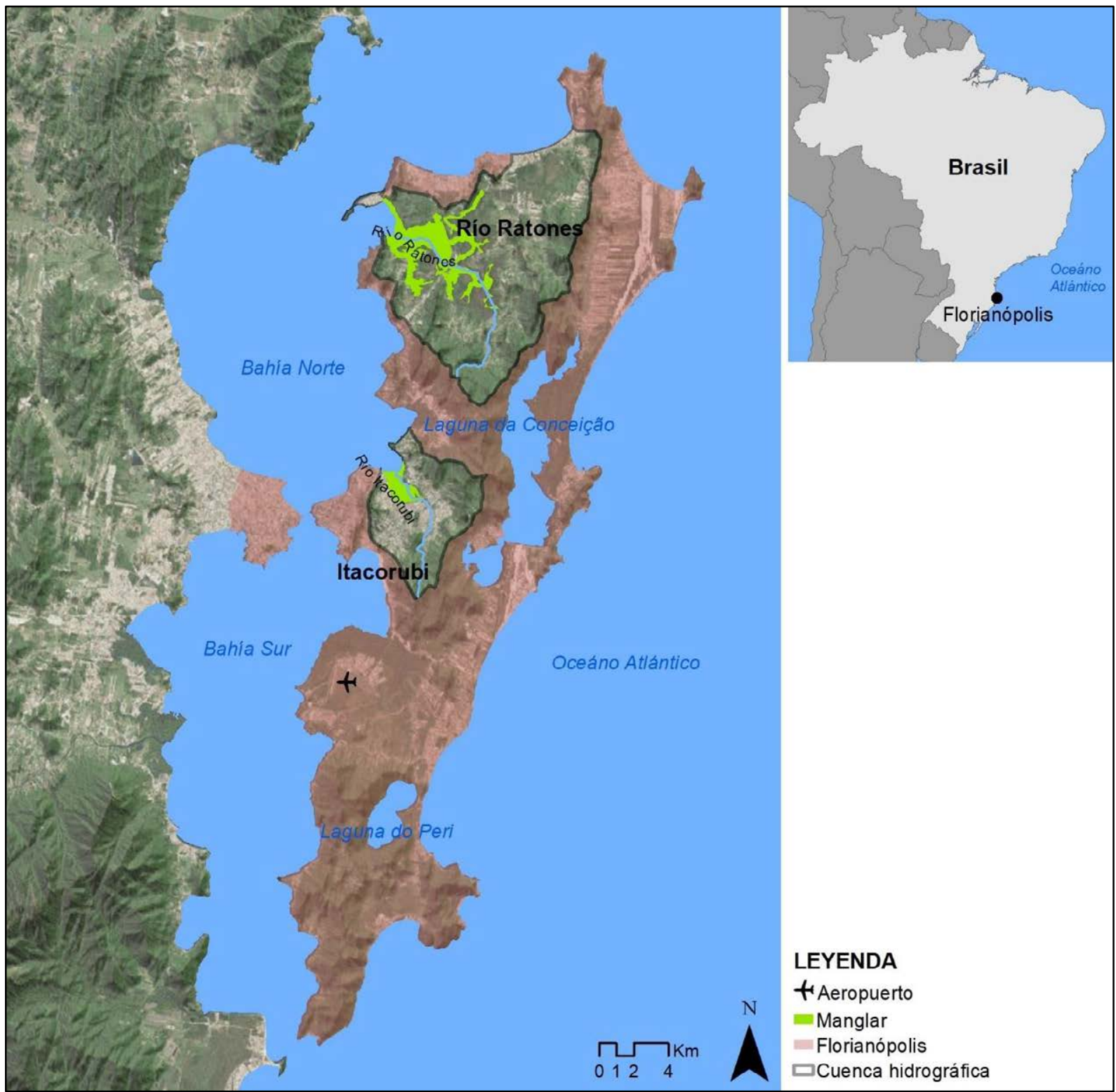

Figura 7.2: Ubicación de los paisajes de manglares del Río Ratones y de Itacorubi. Fuente: Elaboración propia.

La microcuenca del Río Ratones posee una extensa área de llanura de inundación, considerada la más grande de Florianópolis, y una vasta red hidrográfica, donde destaca el Río Ratones. Este hecho favorece la formación del manglar y tiene un área bastante significativa. Los puntos más altos de la microcuenca se sitúan alrededor de los 400 metros. Comprende los barrios de Cachoeira do Bom Jesus, Vargem do Bom Jesus, Vargem Grande, Vargem Pequena, Ratones, Daniela; y parte de los barrios de Jurerê Internacional, Jurerê y Canasvieiras.

La microcuenca de Itacorubi se caracteriza por la existencia de una llanura central rodeada 
de colinas, con predominio de altitud cerca de unos 400 metros. Se destaca como río principal el Río Itacorubi. Está compuesta por los barrios de Trindade, Pantanal, Córrego Grande, Itacorubi; y parte de los barrios Agronómica y João Paulo.

A pesar de la rica biodiversidad, se verificó que la pérdida y fragmentación ambiental es un problema existente en ambos casos. En Río Ratones, el manglar está parcialmente conectado con la vegetación de entorno próximo; y en Itacorubi, el manglar está aislado de la vegetación de entorno próximo. La falta de la conectividad ecológica se ha originado por la ocupación del suelo a lo largo de la historia, a través de la utilización de la agricultura/ganadería, la urbanización y las vías carreteras. Aunque con una utilización del suelo de forma diferenciada para los dos paisajes.

En el ámbito del Río Ratones existe principalmente suelo rural (utilizado para la agricultura y ganadería) y la ubicación de vías de carreteras segmentando el manglar, según se observa en la Figura 7.3. Muchos de los ríos han pasado por grandes obras de drenaje y cambiado sus cursos a través de canalizaciones lineales para la obtención de tierras para la agricultura, ganadería y el desarrollo urbano. Además, según CECCA (1996, p. 81 y 82), el manglar de la localidad ha sufrido una disminución con la construcción de compuertas para evitar la inundación de las mareas, con el objetivo de recuperar un área de seis mil hectáreas destinada a la agricultura.

En cuanto a Itacorubi, el suelo predominante es el urbano. El manglar ha sido segmentado y disminuido por las vías de carreteras, además de terraplenes para la construcción de edificaciones, perjudicando gravemente el manglar de la localidad (Figura 7.4). Los ríos también han pasado por obras de drenaje, que han alterado el comportamiento de la inundación durante las mareas altas. El manglar está considerado como el más amenazado de los manglares de la Región Metropolitana de Florianópolis por estar en la zona de expansión de la urbanización del Municipio. 


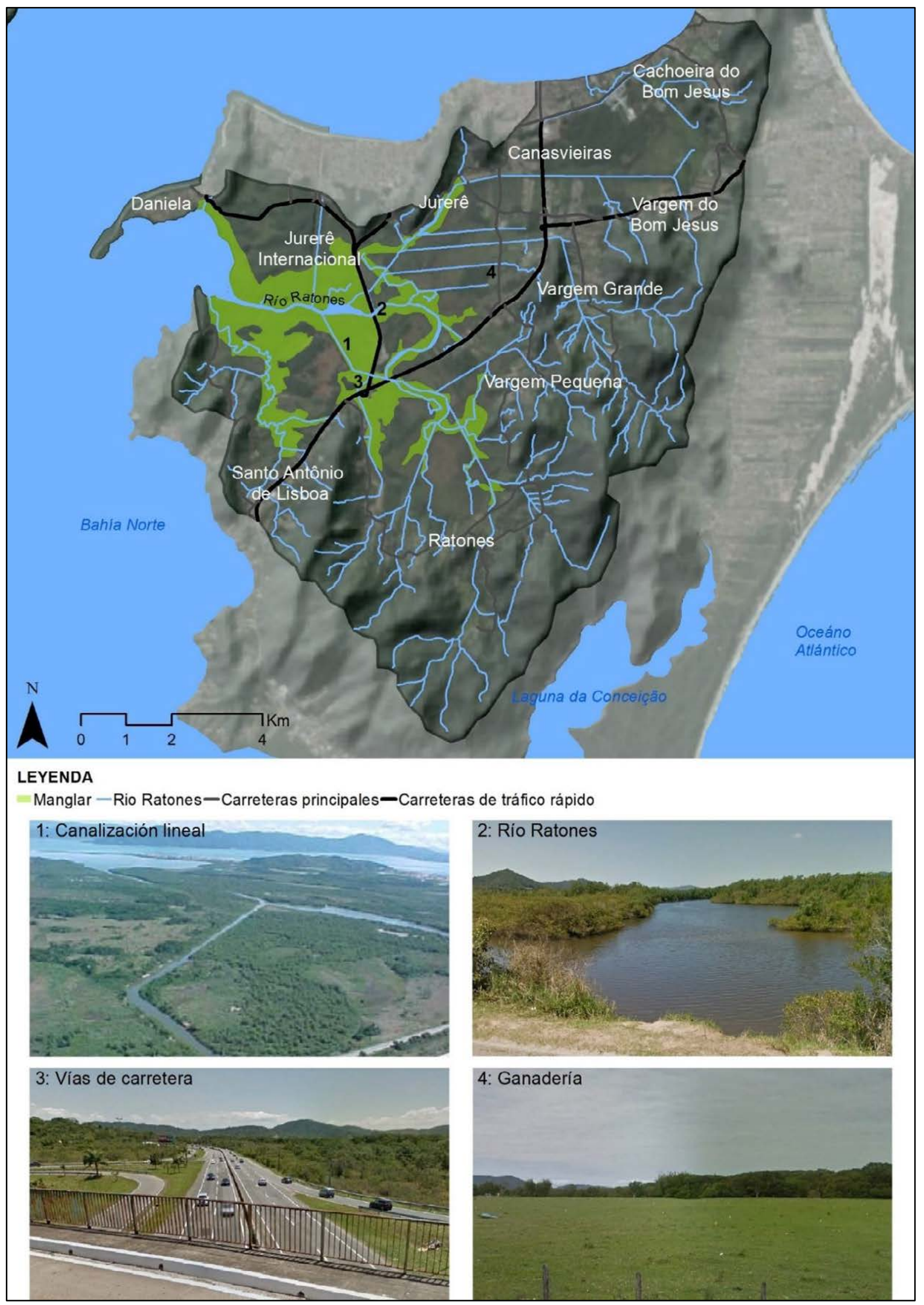

Figura 7.3: Paisaje de manglar del Río Ratones. Fuente: Elaboración propia, imagen 1 (IBAMA, 2003, p. 5, cap. 6) e imágenes 2, 3 y 4 (Google Earth, 2017). 


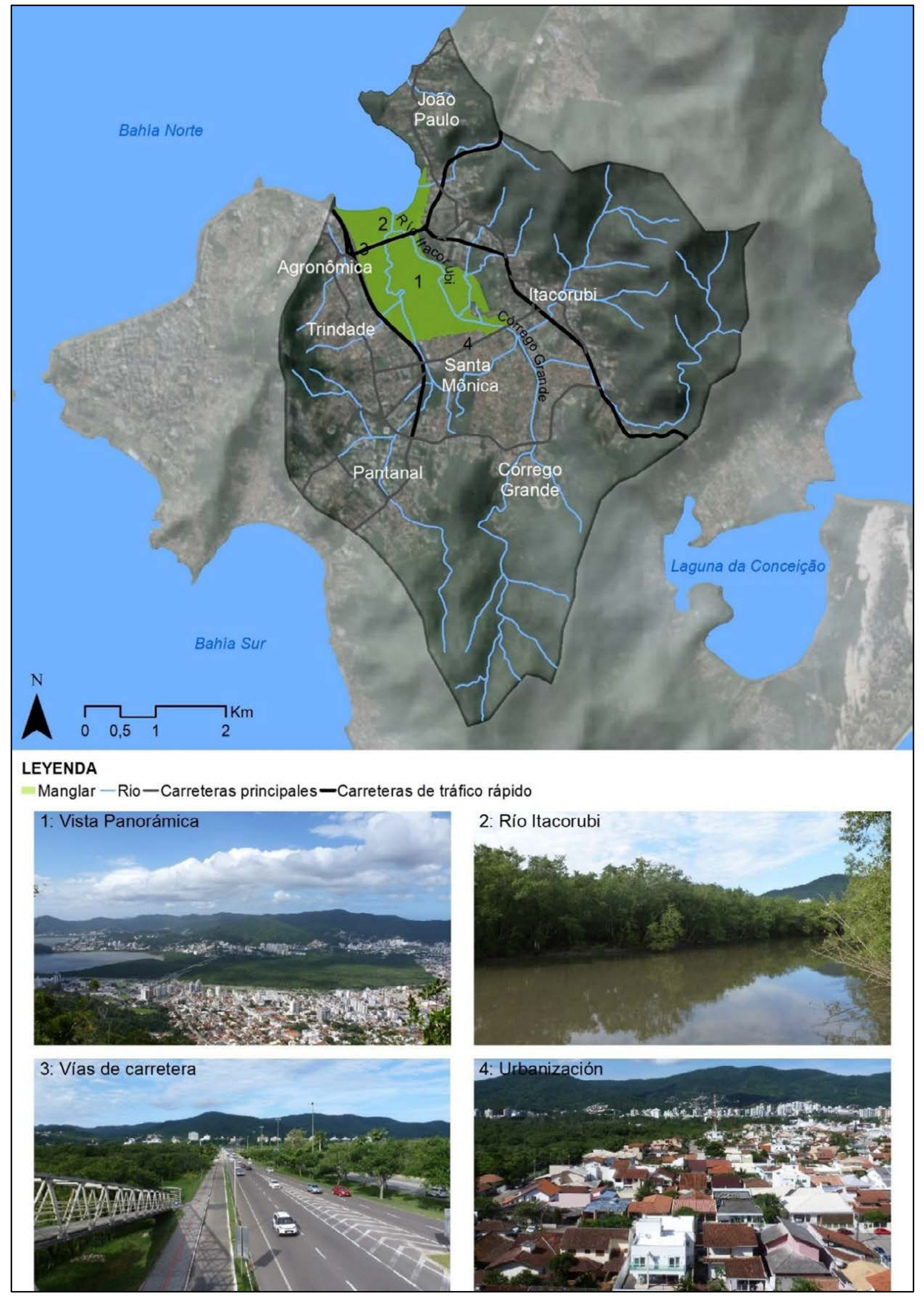

Figura 7.4: Paisaje de manglar de Itacorubi. Fuente: Elaboración propia con fotos del archivo de la autora (2017). 
La degradación del ambiente viene sucediendo sin la actuación de una fiscalización adecuada contra las ocupaciones en áreas previamente preservadas, muestra de una fuerte debilidad en el cumplimiento de las leyes ambientales. De acuerdo con la Figura 7.5, se verifica el mapa de protección ambiental municipal, delimitado para las microcuencas del Río Ratones y de Itacorubi. El mapa está segmentado en cinco áreas, según el Plan Director Municipal de Florianópolis ${ }^{66}$, que se distinguen en:

1. Área de Preservación Permanente: áreas cubiertas o no por vegetación nativa, con la función ambiental de preservar los recursos hídricos, el paisaje, la estabilidad geológica y la biodiversidad; facilitar el flujo de genes de la fauna y la flora, la protección del suelo; y garantizar el bienestar de las poblaciones humanas.

2. Área de Preservación con Uso Limitado: espacios territoriales que, por sus características de relieve, el tipo de vegetación o la vulnerabilidad a los fenómenos naturales, no presentan garantías suficientes para soportar ciertas formas de uso del suelo sin el desequilibrio ecológico o del paisaje natural.

3. Área Verde de Ocio: son espacios urbanos al aire libre de uso y dominio público para la práctica de actividades de ocio y recreación, donde se privilegia, si es posible, la creación o el mantenimiento de la cobertura vegetal.

4. Área de Urbanización Especial: grandes áreas urbanas a partir de un proyecto más amplio. Se reserva el sector predominante a la preservación del medio ambiente y crean nuevos centros que se caracterizan por una mezcla de funciones y espacios humanizados.

5. Área Urbana y Rural: son áreas destinadas a la función urbana (con uso residencial, comercial, servicio y turismo) y rurales de pequeño porte destinadas a la producción agrícola y ganadera familiar.

Las Áreas de Preservación Permanente son de usos no urbanos, con la función de albergar y desarrollar la biodiversidad. Mientras las Áreas de Preservación con Uso Limitado y Área de Urbanización Especial permiten usos urbanos de baja densidad, con la función de proteger las áreas de usos no urbanos y reservar áreas para expansión urbana a largo plazo.

66 Florianópolis (2014). Lei Complementar $n^{\circ}$ 482. Institui o Plano Diretor de urbanismo do Município de Florianópolis que dispõe sobre a política de desenvolvimento urbano, o plano de uso e ocupação, os instrumentos urbanísticos e o sistema de gestão. Diário Oficial, Prefeitura Municipal de Florianópolis. 


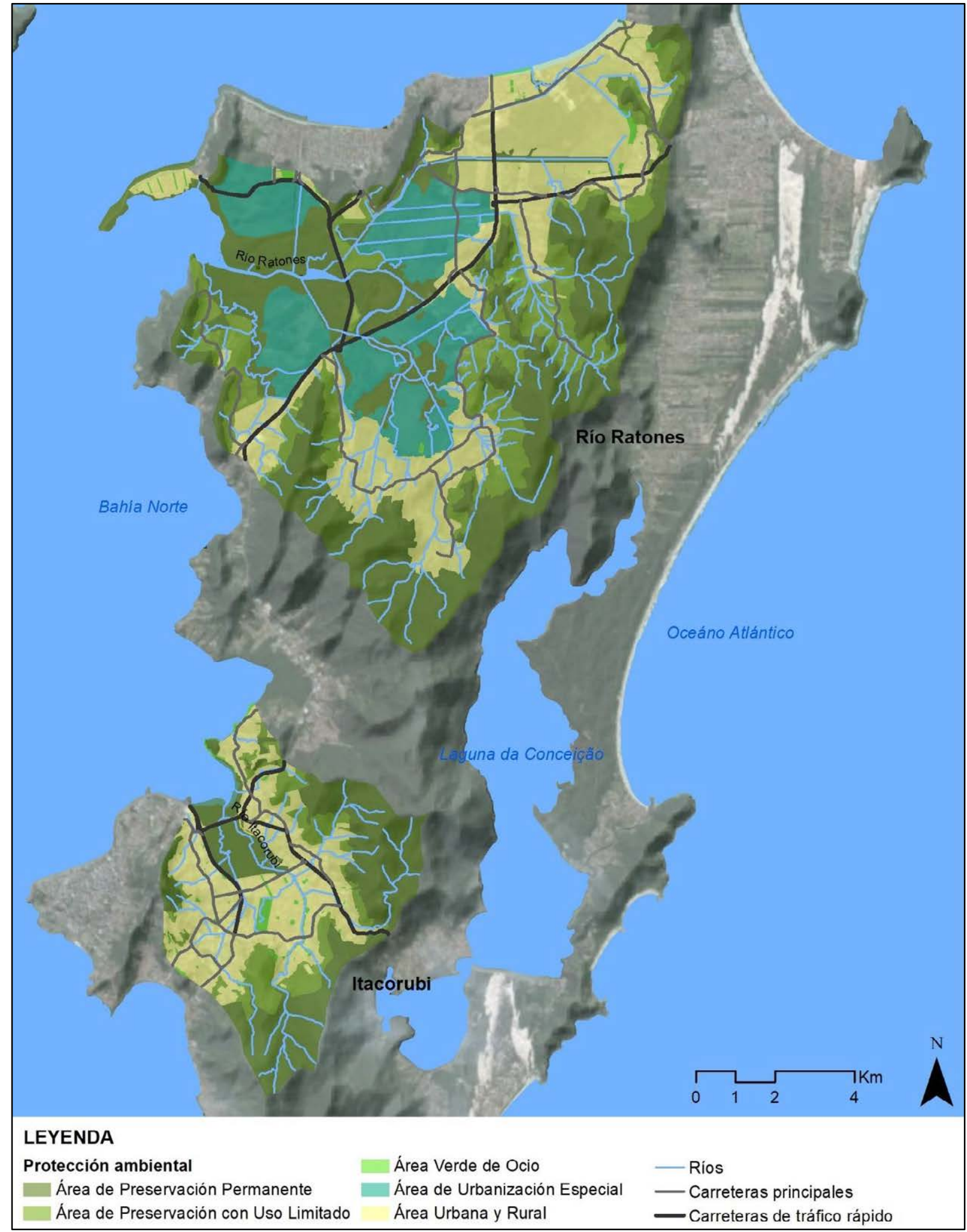

Figura 7.5: Mapa de protección ambiental municipal delimitado para Río Ratones e Itacorubi. Fuente: elaboración propia con los datos cartográficos del Plan Director Municipal (Florianópolis, 2014). 
Además de la delimitación del Área de Preservación Permanente, los manglares de estudio también pertenecen a la Reserva de la Biosfera Mata Atlántica y están protegidos por Unidades de Conservación (Ley $n^{\circ}$ 9.985/2000) ${ }^{67}$. El manglar del Río Ratones pertenece a la Estación Ecológica Carijós (Unidad de Conservación Federal), destinado a la preservación de la naturaleza y la realización de investigaciones científicas. El manglar de Itacorubi corresponde al Parque del Manglar de Itacorubi (Unidad de Conservación Municipal), que, además de destinado a la preservación de la naturaleza y la realización de investigaciones científicas, promueve el desarrollo de actividades de educación, recreación y del turismo ecológico.

Aunque la degradación viene a partir de una falta de fiscalización de la protección ambiental, todavía carecen de estrategias adecuadas del manejo de los espacios naturales en lo que se refiere a facilitar el flujo de genes de la fauna y la flora para la supervivencia de las especies. Sin embargo, con los estudios de la conectividad ecológica, es posible mantener la conexión de los manglares con la vegetación de entorno próximo, como alternativa de planeamiento para la reestructuración de la fauna y flora local y la conservación de los servicios ecosistémicos.

\subsection{ESPECIE DE ESTUDIO}

El conocimiento del movimiento de las especies de la fauna es una forma eficaz para la creación de métodos de conservación del medio ambiente. Según Zeller et al. (2012), el movimiento depende de sus procesos biológicos, donde están incluidos la alimentación, el apareamiento, la migración, la dispersión y el flujo de genes, con una realización muy crítica de estos aspectos en un entorno cambiante.

Para el desarrollo de este estudio, se seleccionó la especie Lontra longicaudis de la Familia Mustelidae, conocida popularmente como nutria neotropical, lobito del río, perro de agua o lontra neotropical ${ }^{68}$. Posee la anatomía alargada, las patas son cortas, tiene garras fuertes y su pelo es de color pardo. Su longitud y peso promedio es de $1,48 \mathrm{~m}$ y 20,1 kg para los machos y de $1,18 \mathrm{~m}$ y $13,5 \mathrm{~kg}$ para las hembras (Gallo-Reynoso, 1989). Esta especie tiene un amplio rango de distribución geográfica en América Central y América del Sur, y ocupa una gran área de Brasil (Figura 7.6). Sin embargo, está incluida en la Lista Oficial de las especies de la fauna

${ }^{67}$ Brasil (2000). Lei n 9.985. institui o Sistema Nacional de Unidades de Conservação da Natureza e dá outras providências.

${ }^{68}$ Nombre conocido popularmente en Brasil. 
brasileña amenazadas de extinción (IBAMA, 1989) y en la Lista Roja de la International Union for Conservation of Nature and Natural Resources (IUCN), como peligro de amenaza (Rheingantz y Trinca, 2015).

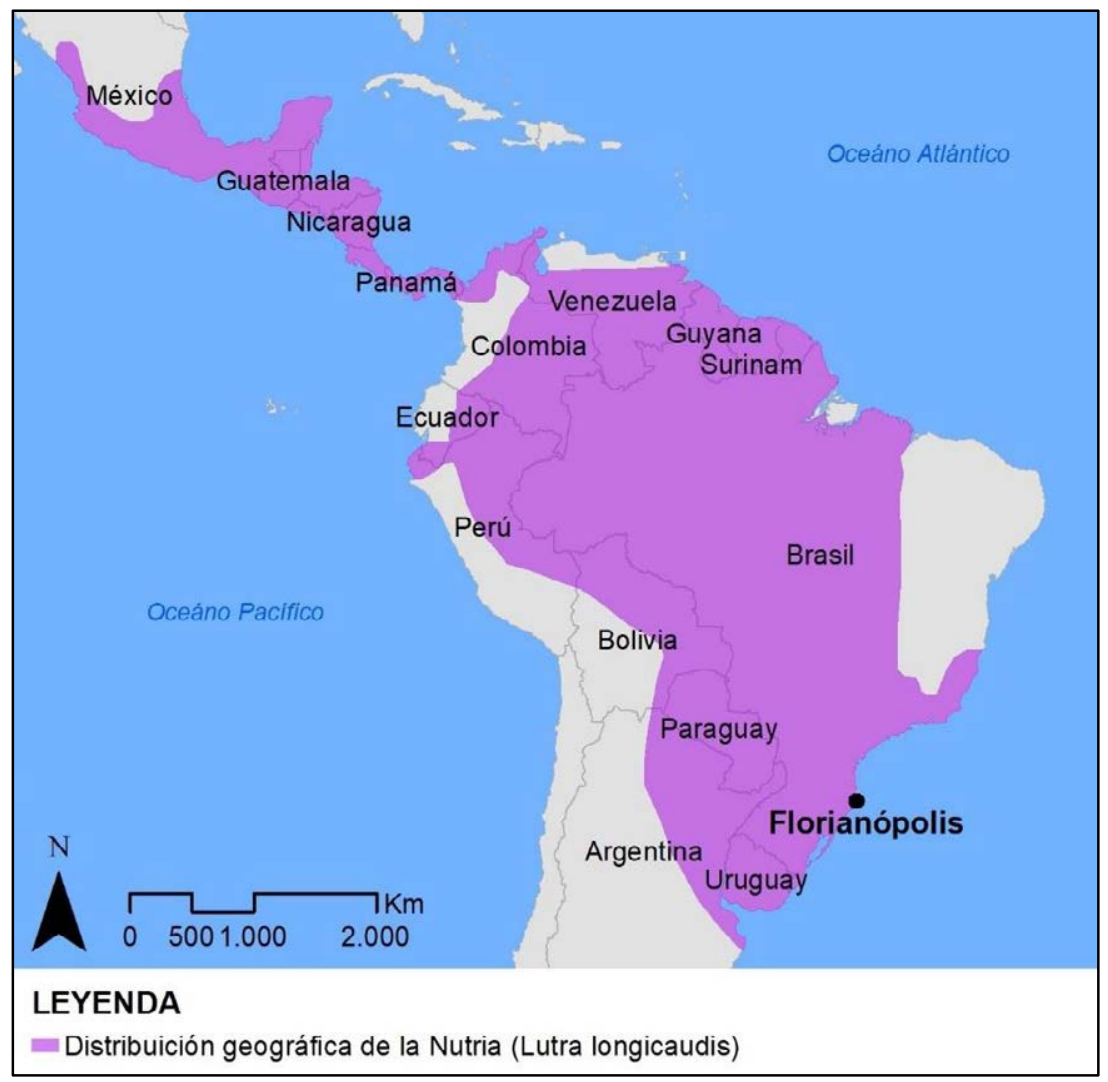

Figura 7.6: Distribución de la nutria neotropical (Lontra longicaudis). Fuente: Elaboración propia con datos disponible en http://www.naturalista.mx (fecha de consulta: enero de 2018).

Se encuentra presente tanto en ambientes acuáticos como en terrestres. Según Olimpio (1990), los manglares de Florianópolis son áreas importantes para la especie como refugio y alimento, pero también está presente en la vegetación circundante. La especie se adapta a una gran variedad de hábitats y altitudes, pero es sensible a las interferencias humanas (GalloReynoso, 1989). El área de dispersión de la especie durante la estación seca oscila entre 2 y 4 km, y de 7 a 9 km en época de lluvias (Gallo-Reynoso, 1989). Según Ortega et al. (2012), la forma más fácil de dispersión es el uso de corrientes de agua para aumentar su velocidad y movilidad.

De acuerdo con Kindlmann y Burel (2008), hay que tener en cuenta que para medir la dispersión existen diferencias entre varias especies o entre la misma especie en momentos distintos, lo que resulta en diferentes grados de conectividad para el mismo paisaje. Conforme se ha mencionado en la Sección 6.2.1.4, en el Municipio de Florianópolis hay la ocurrencia de 
precipitación durante todos los meses del año y la ausencia de una estación seca definida, según la clasificación de Köppen-Geiger (Peel et al., 2007). Por lo tanto, para el estudio de esta especie, se aplicó una dispersión de $8 \mathrm{~km}$, considerando la media del periodo lluvioso descripto por Gallo-Reynoso (1989).

\subsection{PERMEABILIDAD DE PAISAJE}

La permeabilidad de paisaje es un método cuantitativo que verifica cómo la configuración espacial de un paisaje afecta el desplazamiento de los animales, y presenta una interrelación del paisaje estructural con en el paisaje funcional. Esto se da por la resistencia al movimiento de las especies en un paisaje, también llamado de fricción o impedancia para muchos autores. De acuerdo con Zeller et al. (2012), el termino resistencia representa "la disposición de un organismo para cruzar un entorno particular, el costo fisiológico de moverse a través de un entorno particular, la reducción de la supervivencia del organismo que se mueve a través de un entorno particular o la integración de todos estos factores".

En un paisaje heterogéneo, se pueden tener diversos valores de resistencia, que dependen de la característica de movimiento de cada especie de animal en particular. Siendo que una baja resistencia denota una facilidad de movimiento y una alta resistencia, una restricción al movimiento (Zeller et al., 2012). Este análisis se aplica en paisajes ambientalmente degradados, como son los casos de los paisajes de manglares del Río Ratones y de Itacorubi. Por lo tanto, para verificar la permeabilidad de ambos paisajes, se necesitan establecer los valores de resistencia de acuerdo con el conocimiento de la movilidad de la especie de estudio, atribuidos a la configuración espacial de cada paisaje, desarrollada en las secciones siguientes.

\subsubsection{Configuración espacial del paisaje}

La configuración espacial de los paisajes de manglares del Río Ratones y de Itacorubi se determinaron según sus categorías de paisaje, que están relacionadas con los factores naturales (flora y ríos) y humanos (uso del suelo y vías de carreteras). Para este estudio, cada categoría está caracterizada según la Tabla 7.1. 


\begin{tabular}{|c|c|c|c|}
\hline Factores & \multicolumn{2}{|c|}{ Categorías de paisaje } & Caracterización \\
\hline \multirow{6}{*}{ Naturales } & \multirow{5}{*}{ Flora } & Manglar & Vegetación de manglar y vegetación asociada \\
\hline & & Vegetación densa & $\begin{array}{l}\text { Vegetación Pluvial Tropical original o secundaria en } \\
\text { etapa avanzada de plantación }\end{array}$ \\
\hline & & Vegetación poco densa & $\begin{array}{l}\text { Vegetación Pluvial Tropical secundaria en etapa } \\
\text { intermedia de plantación }\end{array}$ \\
\hline & & $\begin{array}{l}\text { Vegetación arbustiva y/o } \\
\text { herbácea }\end{array}$ & $\begin{array}{l}\text { Vegetación Pluvial Tropical secundaria en etapa inicial } \\
\text { de plantación y/o vegetación de restinga }\end{array}$ \\
\hline & & Vegetación exótica & Vegetación de Pinos y/o Eucalipto \\
\hline & Ríos & Ríos & Pertenecientes a las dos cuencas \\
\hline \multirow{4}{*}{ Humanos } & \multirow{2}{*}{$\begin{array}{l}\text { Uso del } \\
\text { suelo }\end{array}$} & Rural & $\begin{array}{l}\text { Área devastada para la Agricultura, ganadería u otros } \\
\text { fines, en utilización o abandonada }\end{array}$ \\
\hline & & Urbano & Edificaciones y calles locales \\
\hline & \multirow{2}{*}{$\begin{array}{l}\text { Vías de } \\
\text { carreteras }\end{array}$} & Carreteras principales & Anchura entre 9 y $20 \mathrm{~m}$, con velocidad hasta $60 \mathrm{Km} / \mathrm{h}$ \\
\hline & & Carreteras de tráfico rápido & Anchura más de $20 \mathrm{~m}$, con velocidad hasta $80 \mathrm{Km} / \mathrm{h}$ \\
\hline
\end{tabular}

Tabla 7.1: Categorías de paisaje determinadas para Río Ratones e Itacorubi. Fuente: Elaboración propia.

Para la elaboración del mapa de la configuración espacial de ambos paisajes (Figura 7.7) se utilizaron los siguientes datos cartográficos de la localidad: microcuencas hidrográficas (Epagri, 2007), tipologías de vegetación (Klein, 1978), vegetaciones remanentes (SAR, 2005) y cobertura vegetal de la Isla de Santa Catarina - 1978 (Caruso, 1981). Todos los mapas fueron actualizados y adecuados según las imágenes satélites más recientes de World Imagery, Esri (2017) y la visita de campo. El área y porcentaje de cada categoría de paisaje está verificada en la Tabla 7.2. 


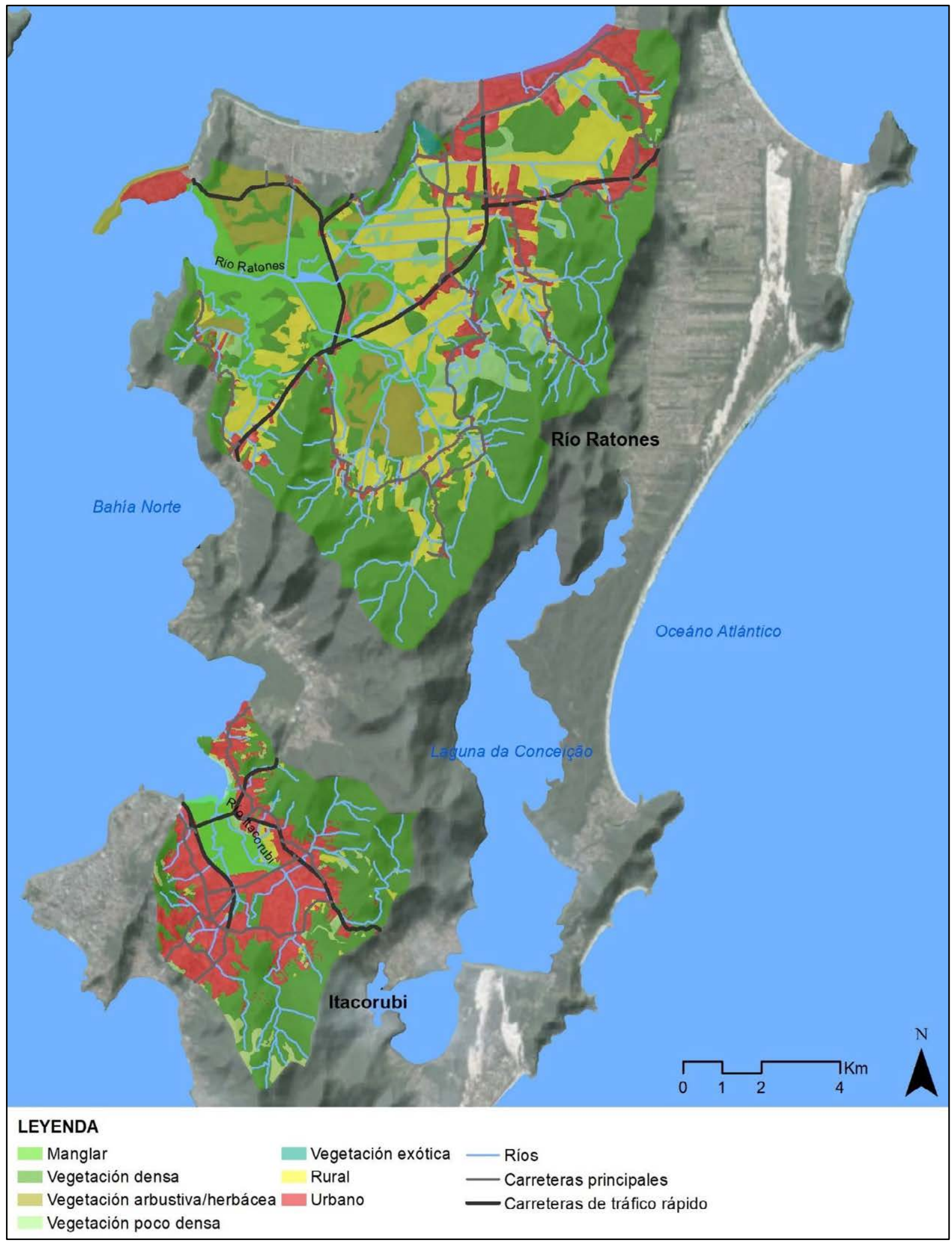

Figura 7.7: Configuración espacial de los paisajes del Río Ratones y de Itacorubi. Fuente: Elaboración propia. 


\begin{tabular}{|l|c|c|c|c|}
\hline \multirow{2}{*}{ Categorías de paisaje } & \multicolumn{2}{|c|}{ Río Ratones } & \multicolumn{2}{c|}{ Itacorubi } \\
\cline { 2 - 5 } & $\mathrm{Km}^{2}$ & $\%$ & $\mathrm{Km}^{2}$ & 7,14 \\
\hline Manglar & 13,19 & 11,35 & 2,02 & 49,69 \\
\hline Vegetación densa & 52,21 & 44,92 & 14,05 & 1,65 \\
\hline Vegetación poco densa & 5,92 & 5,09 & 0,47 & 3,10 \\
\hline Vegetación arbustiva y/o herbácea & 8,70 & 7,48 & 0,88 & 0,06 \\
\hline Vegetación exótica & 0,38 & 0,33 & 0,02 & 1,92 \\
\hline Rural & 22,78 & 19,60 & 0,54 & 36,43 \\
\hline Urbano & 13,05 & 11,23 & 10,30 & 100,00 \\
\hline Total & 116,24 & 100,00 & 28,27 & 2 \\
\hline
\end{tabular}

Tabla 7.2: Área y porcentaje de las categorías de paisaje del Río Ratones y de Itacorubi. Fuente: Elaboración propia.

\subsubsection{Valores de resistencia}

Tras delimitar la configuración espacial de los dos paisajes de estudio, se establecieron los valores de resistencia para cada categoría (Tabla 7.3). El desplazamiento de la especie estudiada depende de estos valores para poder transitar entre los hábitats, donde los valores bajos indican una facilidad de movimiento, y los valores altos, una dificultad de movimiento en el paisaje. Los valores se basaron en los estudios de Adriaensen et al. (2003), determinados para los animales terrestres que habitan los bosques, adaptados para los paisajes de manglares del Río Ratones y de Itacorubi.

\begin{tabular}{|c|c|c|}
\hline \multicolumn{2}{|r|}{ Categorías de paisaje } & Valores \\
\hline \multirow{5}{*}{ Flora } & Manglar & 1 \\
\hline & Vegetación densa & 2 \\
\hline & Vegetación poco densa & 5 \\
\hline & Vegetación arbustiva y/o herbácea & 30 \\
\hline & Vegetación exótica & 20 \\
\hline Ríos & Ríos & 1 \\
\hline \multirow{2}{*}{ Uso del suelo } & Rural & 30 \\
\hline & Urbano & 100 \\
\hline \multirow{2}{*}{ Vías de carreteras } & Carreteras principales & 100 \\
\hline & Carreteras de tráfico rápido & 250 \\
\hline
\end{tabular}

Tabla 7.3: Valores de resistencia al desplazamiento de la especie de estudio (entre 1 y 250). Fuente: Elaboración propia.

El manglar se considera el hábitat principal de la especie de estudio $\mathrm{y}$, por este motivo, tiene el valor mínimo de resistencia. La flora nativa de entorno próximo se calculó de acuerdo con 
su estructura vegetal o según las etapas de regeneración de plantación: vegetación densa, vegetación poco densa y vegetación herbácea y/o arbustiva. En cuanto al uso del suelo, las áreas urbanizadas son más perturbadoras ambientalmente (con alto valor de resistencia) que las áreas rurales, ya que esta última puede regenerarse de forma natural con mayor facilidad. Para la especie de estudio, el río es un elemento de conexión, de baja resistencia, y las vías de carreteras funcionan como una restricción para la conexión (con alto valor de resistencia), que varía según la anchura y la velocidad del tráfico.

A partir de la definición de los valores de resistencia, se originó el mapa de permeabilidad de paisaje, mediante el software SIG (Figura 7.8). Se regeneró un raster a través de la herramienta Weighted Overlay de ArcGis 10.3, donde cada pixel originado (5 m x $5 \mathrm{~m}$ ) tiene un valor determinado de resistencia (referente a los valores de la Tabla 7.3). La elección del tamaño de los pixeles es muy importante, y depende de la escala del sitio a ser analizado, para que se visualicen todos los elementos de paisaje necesarios al análisis. Asimismo, hay que tener en cuenta que los elementos en forma de línea (como los ríos y las vías de carreteras) deben tener una anchura mayor que los pixeles, en caso contrario desaparecerán de la figura de raster y se obtendrá un análisis equivocado.

Estos valores son el resultado de una combinación de dos capas, cada una con un peso distinto. Se adoptó un valor de influencia de un $60 \%$ para la flora y el uso del suelo, y un $40 \%$ para los ríos y las vías de carreteras. Lo que implica una alteración de los valores de resistencia de los ríos y de las vías de carreteras en función de su entorno circundante. Por ejemplo, las secciones de un río cerca de la densidad urbana tienen una mayor resistencia que otras secciones del mismo río cerca de una zona verde. 


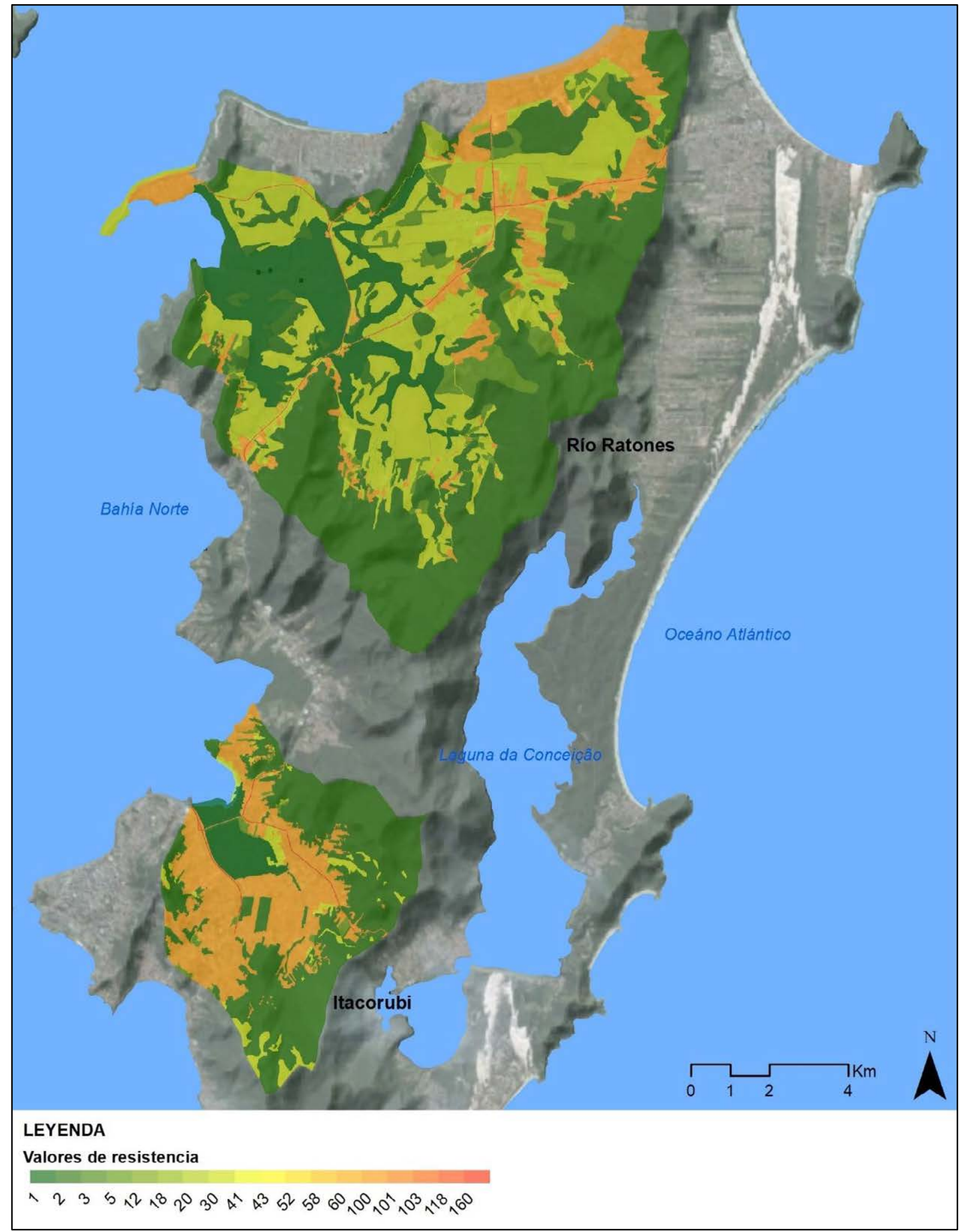

Figura 7.8: Mapa de permeabilidad de paisaje del Río Ratones y de Itacorubi. Fuente: Elaboración propia. 


\subsection{CONEXIONES POTENCIALES}

Las conexiones potenciales, o distancias efectivas, se originan a través del mapa de permeabilidad de paisaje. Estas conexiones simulan las rutas de menor costo de la especie para garantizar la conectividad ecológica (Adriaensen et al., 2003). Chardon et al. (2003) afirman que la incorporación de la resistencia en el paisaje para medir la distancia más corta entre los hábitats proporciona mejores resultados que la distancia euclidiana (distancia geométrica entre dos puntos).

Para verificar las rutas de menor costo, primero se identificaron los hábitats de la especie de estudio en Río Ratones e Itacorubi. Para este estudio, se determinó que tanto los manglares como la vegetación densa corresponden a los hábitats de supervivencia de la especie debido a sus bajos valores de resistencia. En el paisaje del Río Ratones se identificaron 47 fragmentos de hábitats (manglar y vegetación densa), con áreas entre 0,02 y 36,47 km², totalizando $65,40 \mathrm{~km}^{2}$ y un $56,26 \%$ en el paisaje. Respecto a Itacorubi, se identificaron 20 fragmentos de hábitats entre 0,015 y $6,64 \mathrm{~km}^{2}$ de área, sumando un total de $16,07 \mathrm{~km}^{2}$ y un $56,83 \%$ en el paisaje (Figura 7.7 y Tabla 7.2 ).

Las conexiones se obtuvieron a partir de los puntos de origen y destino, ubicados en el centro de gravedad de cada fragmento de hábitat, según se observa en la Figura 7.9. Para este propósito, se utilizaron las herramientas de conectividad Cost Distance, Cost Back Link y Cost Path de ArcGis 10.3, que verifican el camino de mínimo costo entre los hábitats. 


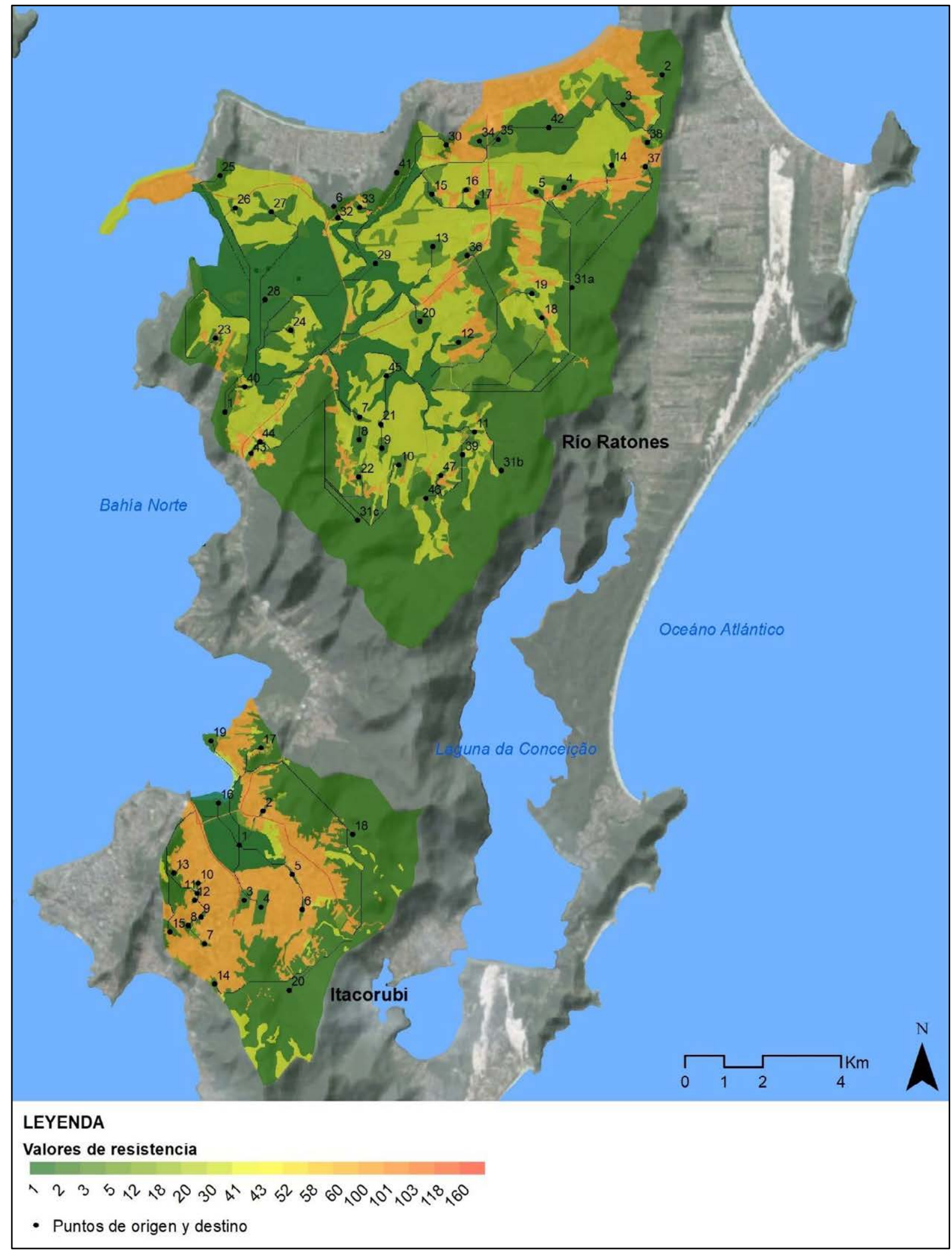

Figura 7.9: Mapa de conexiones potenciales en los paisajes del Río Ratones y de Itacorubi. Esta figura muestra, como ejemplo, la conexión en ambos paisajes a partir del punto 1 , conectando todos los otros puntos. Fuente: Elaboración propia. 
En Río Ratones se originaron 1.171 conexiones potenciales entre todos los puntos de origen y destino. En el fragmento de hábitat representado por el punto 31, debido a la forma y gran extensión, el centro de gravedad se sitúa fuera del límite del área. Para la solución de este problema se segmentó su área en 3 partes (31a, 31b y 31c), con el objetivo de que el centro de gravedad se sitúe dentro de los segmentos. Finalmente, en el paisaje de Itacorubi se generaron 190 conexiones potenciales.

\subsection{MÉTRICAS DE CONECTIVIDAD}

En este subcapítulo se investigaron diferentes métricas de conectividad a partir de una vasta revisión de literatura sobre la Teoría de Grafos. Este método pertenece a una rama de las matemáticas que se ocupa de los problemas de conectividad, adaptado recientemente para los estudios de la ecología del paisaje y la biología de la conservación (Bunn et al., 2000; Urban et al., 2009; Urban y Keitt, 2001). Han surgido muchos estudios con enfoques diferenciado en la medición de la conectividad en el paisaje. Sin embargo, según Saura y Pascual-Hortal (2007), todavía hay una gran necesidad de investigación sobre las propiedades específicas y capacidades de medición de muchas métricas que es esencial para seleccionar los índices más apropiados con una base objetiva y sólida.

La Teoría de Grafos se ha utilizado para medir la conectividad en paisajes fragmentados a través de un conjunto de nodos y enlaces. Los nodos representan los fragmentos de hábitat, mientras que el enlace indica la capacidad potencial de un individuo para dispersarse entre los nodos (Galpern et al., 2011; Urban et al., 2009). Según Kindlmann y Burel (2008), es importante el desarrollo de medidas de conectividades funcionales, que agregan tanto el comportamiento de movimiento de la especie como la estructura del paisaje. Aunque existen muchas medidas desarrolladas como modelos de planificación ambiental, hay pocos estudios que hacen la correlación entre ellas.

En el presente estudio se eligieron las métricas más utilizadas en la literatura de la Teoría de Gráficos para el análisis de la conectividad ecológica. Tras la selección, se propuso un nuevo método para combinar las diferentes medidas en un único valor de conectividad ecológica, entre 0 y 1 para cada fragmento de hábitat (siendo 0 el nodo menos conectado y 1 el más conectado ecológicamente en el paisaje), desarrollado en las secciones siguientes. 


\subsubsection{Selección de las métricas}

La conectividad ecológica puede ser cuantificada a través de modelos de conexiones binarias o probabilísticas (Pascual-Hortal y Saura, 2006; Saura y Pascual-Hortal, 2007). Sin embargo, en el modelo binario no existe una conexión potencial entre cada nodo, se considera solamente que estén conectados o no, dependiendo de la distancia de dispersión. En el modelo probabilístico, las conexiones se caracterizan por una probabilidad de dispersión Pij entre los nodos $i$ y $j$, y tienen un resultado más efectivo en el paisaje (Bunn et al., 2000; Saura y Pascual-Hortal, 2007; Urban y Keitt, 2001).

Por lo tanto, para esta investigación, se seleccionaron seis métricas de modelos probabilísticos de conexión establecidos en la Teoría de Grafos, nombradas como: Flux, AreaWeighted Flux, Probability of Connectivity Index, Influx Potential, Outflux Potential y Metapopulation Capacity. Estas métricas están constituidas por un conjunto de dispersión, nodos y enlaces, adquiridas en los subcapítulos anteriores. La dispersión es la distancia de desplazamiento de la especie de estudio ${ }^{69}$. Los nodos son determinados por las áreas de los fragmentos de habitas de la especie estudiada (manglares y vegetación densa de su entorno próximo, verificada a través de la permeabilidad de paisaje $)^{70}$. Los enlaces son las rutas de menor costo de desplazamiento entre los fragmentos de hábitats, originado de las conexiones potenciales $^{71}$.

Las métricas Flux, Area-Weighted Flux y Probability of Connectivity Index se calcularon a través del Conefor Sensinode 2.6 (Saura y Torne, 2009). Las métricas Influx Potential, Outflux Potential y Metapopulation Capacity por el MATLAB R2016a ${ }^{72}$. Las fórmulas utilizadas para cada una de las métricas mencionadas son las siguientes:

1. Flujo, conocido por el nombre de Flux (F) (Bunn et al., 2000; Urban y Keitt, 2001):

$$
F=\sum_{i=1}^{n} \sum_{j=1, j \neq i}^{n} p_{i j}
$$

2. Flujo ponderado por área, conocido por el nombre de Area-Weighted Flux (AWF) (Bunn et al., 2000; Urban y Keitt, 2001):

\footnotetext{
69 Para este estudio, se aplicó una dispersión de 8 km, según demuestra el subcapítulo 7.2.

70 Verificación de los nodos: subcapítulo 11.1 (anexos).

71 Verificación de los enlaces: subcapítulos 11.2 y 11.3 (anexos).

72 Verificación de los códigos regenerados en el MATLAB: subcapítulo 11.4 (anexos).
} 


$$
A W F=\sum_{i=1}^{n} \sum_{j=1, j \neq i}^{n} p_{i j} a_{i} a_{j}
$$

3. Probabilidad de índice de conectividad, conocido por el nombre de Probability of Connectivity Index (PC) (Saura y Pascual-Hortal, 2007):

$$
P C=A_{L}^{-2} \sum_{i=1}^{n} \sum_{j=1}^{n} a_{i} a_{j} p_{i j}^{*}
$$

4. Potencial de flujo de entrada, conocido por el nombre de Influx Potential (IP) (Malvadkar et al., 2015):

$$
I P=\sum_{i=1}^{n} \sum_{j=i}^{n} p_{i j} a_{j}
$$

5. Potencial de flujo de salida, conocido por el nombre de Outflux Potential (OP) (Malvadkar et al., 2015):

$$
O P=\sum_{i=1}^{n} \sum_{j=1}^{n} p_{i j} a_{i}
$$

6. Capacidad de metapoblación, conocido por el nombre de Metapopulation Capacity (MC) (Hanski y Ovaskainen, 2000):

$$
M C=\lambda_{P}^{\max }
$$

donde $a_{i}$ y $a_{j}$ son las áreas de los nodos $i$ y $j, A_{\llcorner}$es el área total del paisaje, $p_{i j}$ es la probabilidad directa de dispersión entre los nodos $i$ y $j$, y $p_{i j}^{*}$ es la probabilidad de la mejor ruta de todas las rutas posibles entre $i$ y $j$. Por ejemplo, se supone que $p_{i j}$ es igual a $0,6, p_{i q}$ es igual a 0,8 y $p_{j q}$ es igual a 0,8. Entonces, $p_{i j}^{*}$ es igual a la probabilidad máxima de dispersión, o sea, la mejor ruta entre $i$ y $j$ pasando por $q$. Dado que, la probabilidad resultante, $0,8 \times 0,8$ $=0,64$, es mayor que $p_{i j}$. Cuando dos nodos están completamente aislados, $p_{i j}^{*}$ será igual a 0 . En cuanto a $\lambda_{P}^{\max }$, es el valor propio mayor de la matriz $P$, donde $P_{i j}=p_{i j}$ y 0 para $i=j$. La probabilidad de dispersión $p_{i j}$ se calcula como:

$$
p_{i j}=e^{-k d_{i j}}
$$

donde $d_{i j}$ es la distancia entre los nodos y $k$ es una constante. El valor de $k=0,0376$, se 
obtuvo utilizando una probabilidad de dispersión del $5 \%$ para $8 \mathrm{~km}$ de dispersión.

Los resultados de este análisis pueden variar dependiendo de la métrica seleccionada, como se observa en la Tabla 7.4 para los paisajes del Río Ratones y de Itacorubi. Cada una de las métricas tiene puntos débiles y fuertes, por lo que la comparación directa entre ellas es complicada. La métrica F lleva en consideración solamente la probabilidad directa de dispersión. La AWF considera la probabilidad directa, pero ponderada por el área de los dos nodos. La PC lleva en cuenta la probabilidad máxima de dispersión, dando una mayor importancia a las paradas intermediarias (Saura y Pascual-Hortal, 2007), en las que comprenden varios nodos intermediarios hasta llegar al su destino final, aunque la distancia de dispersión sea mayor. La IP considera la probabilidad junto al área del nodo de destino, al revés de $\mathrm{OP}$, que considera la probabilidad junto al área del nodo de origen. Por último, la MC captura el impacto de la conectividad ecológica sobre la persistencia de la metapoblación de especie. Los resultados de la métrica PC tiene un rango entre 0 y 1 (donde el valor 1 es un paisaje ocupado por el $100 \%$ de hábitat) y las otras métricas, entre 0 y $\infty$.

\begin{tabular}{|c|c|c|}
\hline Métricas & Río Ratones & Itacorubi \\
\hline F & 39,212 & 7,918 \\
\hline AWF & $6,563 \mathrm{E}+13$ & $2,452 \mathrm{E}+12$ \\
\hline PC & 0,051 & 0,098 \\
\hline IP & $1,162 \mathrm{E}+08$ & $1,662 \mathrm{E}+07$ \\
\hline OP & $8,729 \mathrm{E}+07$ & $1,691 \mathrm{E}+07$ \\
\hline MC & $1,198 \mathrm{E}+13$ & $5,067 \mathrm{E}+11$ \\
\hline
\end{tabular}

Tabla 7.4: Resultado de las métricas de conectividad ecológica para los paisajes del Río Ratones y de Itacorubi. Fuente: Elaboración propia.

\subsubsection{Valores de conectividad ecológica de cada fragmento de hábitat}

En esta sección se determinaron los valores de conectividad ecológica de cada fragmento de hábitat en los dos paisajes de estudio (según una combinación de las métricas seleccionadas), desarrollada en cuatro etapas. Primero, se obtuvo el valor de cada nodo individual para cada métrica; en seguida se normalizaron estos valores entre 0 y 1 ; luego se realizó el promedio de los valores normalizados; y, por fin, se normalizaron de nuevo los valores entre 0 y 1 , considerando como 0 el nodo menos conectado y 1 el más conectado ecológicamente en el paisaje. 


\section{Etapa 1:}

El valor de cada nodo individual en los paisajes de estudio se obtuvo a partir de PascualHortal y Saura (2006), Saura y Pascual-Hortal (2007) y Urban y Keitt (2001), a través de la siguiente ecuación ${ }^{73}$ :

$$
d X(i)=100 \cdot\left(X-X^{\prime}\right) / X
$$

donde $X$ es el resultado de las métricas de conectividad calculado para el paisaje (teniendo en cuenta todos los nodos del paisaje) y $X^{\prime}$ es el valor de la misma métrica, calculada tras retirar el nodo $i$ del paisaje. En el caso de la métrica MC, la importancia de cada nodo se midió según la fórmula siguiente (Hanski y Ovaskainen, 2000):

$$
\operatorname{dMC}(\mathrm{i})=x(i)^{2} \lambda_{P}^{\max }
$$

donde $x$ es el vector propio asociado al valor propio $\lambda_{P}^{\max }$.

\section{Etapa 2:}

Aunque los valores de $d X$ para todas las métricas tiene un rango mínimo de 0 , el máximo, en general, no tiene un límite, lo que pude variar entre 0 y $\infty$. Por lo tanto, en esta etapa, se propuso normalizar los índices $d X$ de cada métrica entre 0 y 1 , de acuerdo con la ecuación $1^{74}$.

$$
d X_{j}(i)=\frac{d X_{j}(i)-\min \left(d X_{j}\right)}{\max \left(d X_{j}\right)-\min \left(d X_{j}\right)}
$$

\section{Etapa 3:}

Posteriormente, se evaluó la importancia de cada nodo de acuerdo con el promedio de los índices normalizados, nodo por nodo, tal como se puede observar en la ecuación $2^{75}$ :

$$
\bar{X}(i)=N_{m}^{-1} \sum_{j=1}^{N_{m}} d X_{j}(i)
$$

donde $d X_{j}(i)$ se refiere a la importancia del nodo $i$ para la medida $j$ y $N_{m}$ es el número total de métricas.

\footnotetext{
73 Verificación de los resultados: subcapítulos 11.5 y 11.6 (anexos).

74 Verificación de los resultados: subcapítulos 11.7 y 11.8 (anexos).

75 Verificación de los resultados: subcapítulo 11.9 (anexos).
} 


\section{Etapa 4:}

Finalmente, a partir de los resultados obtenidos de la ecuación 2, se normalizaron los nodos una vez más entre 0 y 1 (utilizando la ecuación 1), determinando el valor de conectividad ecológica de cada fragmento de hábitat. Se adoptó como 0 el nodo menos conectado y 1 como el más conectado ecológicamente en el paisaje ${ }^{76}$.

\subsection{DIAGNÓSTICO}

De acuerdo con los análisis de los resultados, es posible verificar que el orden del fragmento de hábitat más conectado al menos conectado ecológicamente en el paisaje, dado por la combinación de las métricas, no se asocia a ninguna métrica específica. Como se ha mencionado anteriormente, cada métrica tiene sus propias directrices para evaluar la conectividad, y la combinación de ellas representa una síntesis de todas las métricas. Por ejemplo, en Río Ratones, el nodo considerado más conectado (nodo 28) (Figura 7.10), está igualmente valorado por las métricas AWF, OP y MC. En las métricas F, PC e IP, este mismo nodo representa los valores $0,876,0,781$ y 0,858 , respectivamente. En cuanto a Itacorubi, el nodo más conectado (nodo 18) (Figura 7.10), está igualmente valorado por las métricas AWF, PC, IP, OP. Sin embargo, en las métricas F y MC, este nodo representa los valores 0,061 y 0,692 , respectivamente.

A partir del valor de la conectividad ecológica de cada fragmento de hábitat a través de la combinación de las métricas, se identificaron los fragmentos de hábitat más críticos y se analizaron de forma estructural y funcional en los dos paisajes de manglares de estudio. En un rango entre 0 y 1 (menos conectado y más conectado, respectivamente), los nodos se dividieron según su valor de conectividad ecológica. Se consideraron los nodos más críticos los que están en los $25 \%$ de los valores más bajos, crítico los que están más de $25 \%$ e inferior a $75 \%$ y menos crítico los que están más de $75 \%$. La división en rangos es siempre subjetiva y debe ser elegida de acuerdo a lo que más se adecua al estudio. Posteriormente, se relacionaron estos fragmentos más críticos con las figuras de protección ambiental vigentes, diferenciadas en tres categorías para este estudio: áreas protegidas (consideradas las Áreas de Preservación Permanente), áreas parcialmente protegidas (que son las Áreas de Preservación con Uso Limitado, las Áreas de Urbanización Especial y las Áreas Verdes de Ocio) y áreas sin protección ambiental (consideradas las Áreas Urbana y Rural) (Figura 7.10).

\footnotetext{
76 Verificación de los resultados: subcapítulo 11.10 (anexos).
} 


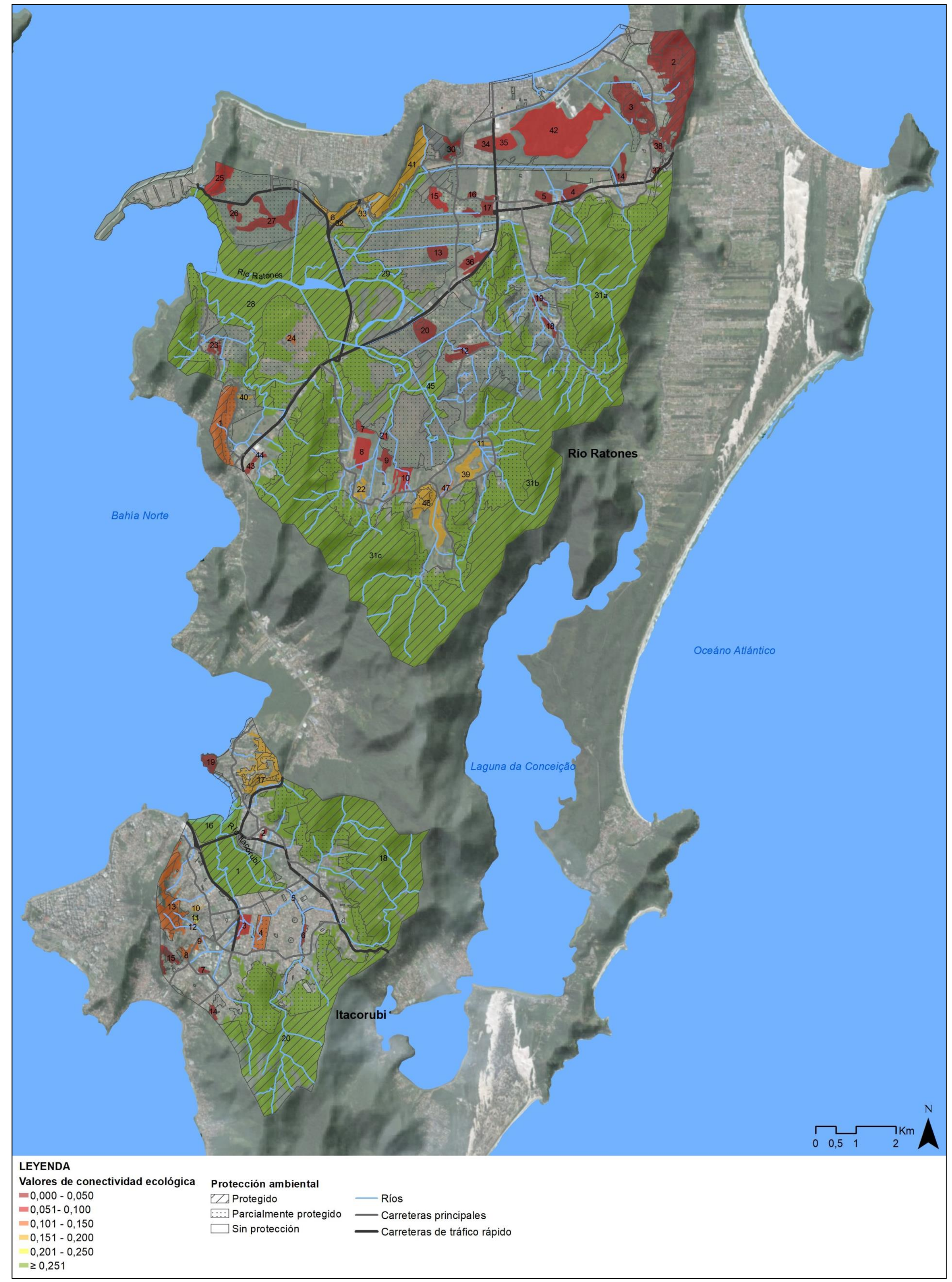

Figura 7. 10: Valores de conectividad ecológica de los fragmentos de hábitat más críticos y figuras de protección ambiental de los paisajes del Río Ratones y de Itacorubi. Para el nodo 31 (Río Ratones), subdividido entre 31a, 31b y 31c, se obtuvo un valor único, a través de su promedio ponderado por área. Fuente: Elaboración propia. 

En Río Ratones, de un total de 47 nodos, 43 están considerados como más críticos, un total de $11,91 \mathrm{~km}^{2}$ de los $65,41 \mathrm{~km}^{2}$ de fragmentos de hábitat existentes. En cuanto a Itacorubi, de los 20 nodos, 16 están considerados como más críticos, con un total de $2,00 \mathrm{~km}^{2}$ de los 16,07 $\mathrm{km}^{2}$ de fragmentos de hábitat existentes. Aunque el $81,78 \%$ del área de los fragmentos de hábitat está en el intervalo de menos críticos en Río Ratones, el 91,49\% de los nodos están en el intervalo de los más críticos. Una proporción semejante ocurre en Itacorubi, donde el $87,56 \%$ del área de los fragmentos de hábitat está en el intervalo de los menos críticos y el $80,00 \%$ de los nodos está en el intervalo de los más críticos. En un aspecto general, el tamaño reducido de área de los hábitats ofrece un gran riesgo para la conectividad ecológica.

Sin embargo, no solamente el área influye para la conectividad ecológica. Entre los nodos más críticos en Río Ratones, el nodo 14 tiene el valor más bajo de conectividad, con un área de $0,12 \mathrm{~km}^{2}$, mientras que el nodo 32 posee el valor más alto de conectividad, 0,194, con un área menor, de $0,029 \mathrm{~km}^{2}$. En Itacorubi, el nodo 6 tiene el valor más bajo de conectividad, con un área de 0,036 km², mientras que el nodo 11 tiene el valor más alto de conectividad, 0,211, con un área menor, de $0,016 \mathrm{~km}^{2}$. Esto demuestra que el valor de la conectividad es también el resultado de la distribución espacial de estos nodos en el paisaje, diferenciados en los aspectos estructural y funcional.

En el aspecto estructural, los nodos más críticos, principalmente los de valores de conectividad entre 0 y 0,05 , están más aislados, ocupando espacios distantes de los otros nodos. En un aspecto funcional, estos nodos se sitúan donde predomina el uso urbano y las vías de carreteras, lo que dificulta el movimiento de la especie de estudio entre los hábitats por su alto valor de resistencia en el paisaje. Tales cuestiones están verificadas en los dos paisajes de manglares de este estudio, pero de forma distinta.

Tanto en Río Ratones, como Itacorubi, el porcentaje de los fragmentos de hábitat tiene una proporción similar con respecto a las áreas de sus microcuencas hidrográficas. Sin embargo, la principal característica que los diferencian es el porcentaje del uso del suelo en el paisaje. En Río Ratones posee un $19,59 \%$ de área rural y un 11,23\% de área urbana. En este caso, los nodos más críticos, principalmente aquellos con valores entre 0 y 0,05 , se relacionan con el uso urbano. Por otro lado, Itacorubi está más urbanizado en relación al uso del suelo, con un $36,43 \%$ urbano y apenas un 1,92\% rural. En este último paisaje, prevalece la ocupación de los nodos más críticos, principalmente los de valores entre 0 y 0,05 , en los espacios más aislados de hábitats y/o cerca de las vías de carreteras.

Aunque los manglares de ambos paisajes no están incluidos como fragmentos de hábitat más 
críticos, debido a su extensión de área y localización espacial (estructural y funcional), la conexión con la vegetación de entorno próximo es considerada fundamental para la conservación de sus servicios ecosistémicos. Por lo tanto, se hace necesaria la restauración de los nodos más críticos y el mantenimiento de los menos críticos con leyes apropiadas.

De acuerdo con el análisis de las figuras de protección ambiental vigentes en los fragmentos de hábitats más críticos en Río Ratones, se verificó que el 26,52\% está protegido, el 32,21\% se encuentra parcialmente protegido y el $41,27 \%$ está sin protección. En cuanto a Itacorubi, el $30,00 \%$ está protegido, el $32,85 \%$ está parcialmente protegido y el $37,15 \%$ está sin protección $^{77}$. En las áreas sin protección o parcialmente protegido, debería ser aplicado una gestión ambiental para la protección de estos fragmentos, con una fiscalización activa.

Asimismo, se hace necesario delimitar otras áreas de protección ambiental que faciliten el restablecimiento de la vegetación nativa, con el propósito de crear una conexión ecológica entre los ecosistemas. En este aspecto, los estudios de las conexiones potenciales, que indican las rutas de menor costo, podrían sugerir las áreas de prioridad para posibilitar el desplazamiento de la especie de estudio en los paisajes de manglares.

77 Verificación de la protección ambiental por nodo (más críticos): subcapítulos 11.11 y 11.12 (anexos). 


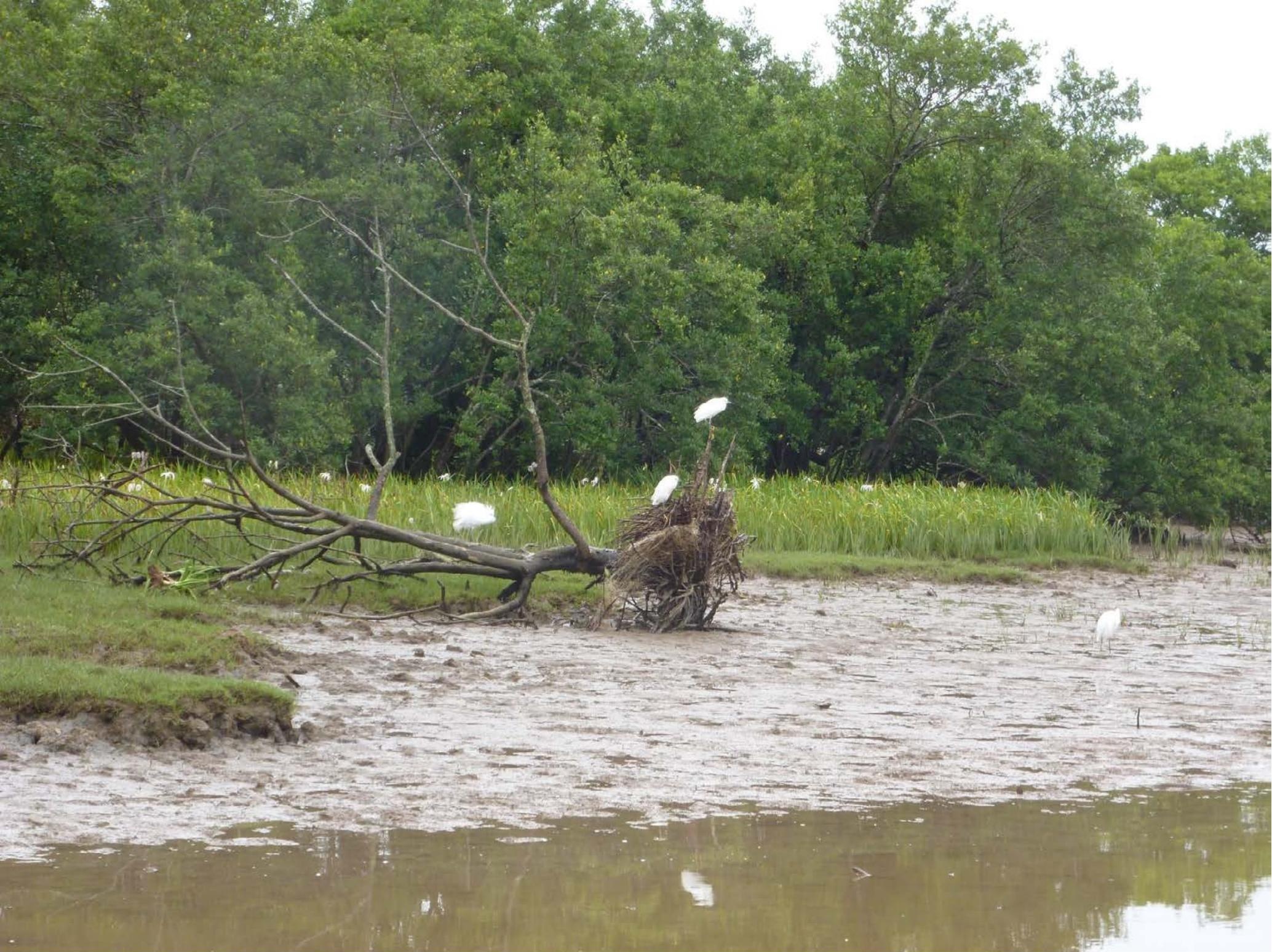

\section{PARTE IV}

CONCLUSIONES Y LÍNEAS DE INVESTIGACIONES

FUTURAS 


\section{CONCLUSIONES}

Este capítulo se dedica a las principales conclusiones a partir de los resultados obtenidos en los capítulos anteriores, sobre lo que se espera según la hipótesis de la investigación, relacionándolos con los objetivos propuestos. Están desarrollados en los siguientes subcapítulos:

8.1 CARACTERIZACIÓN DE LOS PAISAJES DE MANGLARES: conclusión sobre la evaluación del ecosistema de los manglares, su enlace con la ocupación del suelo y los impactos generados, relacionándolos con las figuras de protección ambiental en los ámbitos internacional, nacional y municipal, que afectan a los ubicados en la Región Metropolitana de Florianópolis.

8.2 CONECTIVIDAD ECOLÓGICA EN LOS PAISAJES DE MANGLARES: conclusión sobre la importancia de la conectividad ecológica en los paisajes de manglares, demostrando estrategias adecuadas para que los mismos puedan proporcionar sus servicios ecosistémicos, según el análisis en los paisajes menos y más afectados de la Región Metropolitana de Florianópolis. 


\subsection{CARACTERIZACIÓN DE LOS PAISAJES DE MANGLARES}

Como se ha verificado en el subcapítulo 3.2 COMPONENTES ECOSISTÉMICOS, el grado de desarrollo de los manglares está condicionado por los componentes abióticos, o sea, los factores físicos en que vive. Respecto a esto, en Brasil, considerado como el segundo país con mayor extensión de manglares del mundo, los manglares se desarrollan con más abundancia y mayor estructura en la costa Norte, mientras disminuyen en la Costa Sur de Brasil.

En la Región Metropolitana de Florianópolis, los aspectos abióticos para la existencia de los nueve manglares existentes son favorables, a pesar de estar en el límite Sur respecto a las áreas con presencia de manglares del continente americano, analizado en la sección 3.2.3 Manglares en Brasil. Según muestra en la sección 6.2.1 Componentes abióticos, el desarrollo se debe al clima cálido en las regiones subtropicales y a estar protegidos por las Bahías Norte y Sur de las olas fuertes. Además, la topografía propicia áreas protegidas de las corrientes marinas e inundaciones producidas por el régimen de marea, formando sedimentos. Igualmente, los ríos en estas localidades son de extrema importancia para la formación de los manglares, denominándose como manglares marítimo-fluviales por relacionarse con sus cuencas hidrográficas.

En relación a los componentes bióticos (sección 6.2.2 componentes bióticos), la flora de los manglares de la Región Metropolitana de Florianópolis presenta un grado de desarrollo notable a pesar de su proximidad al límite latitudinal (Cintrón y Schaeffer-Novelli, 1981). Existe una zonificación gradual para cada especie de manglar y las vegetaciones asociadas en el territorio. Sin embargo, se constató una variación estructural en forma de mosaico en el manglar de Río Ratones, según los estudios de Silva (1990), por estar originadas en épocas distintas de sedimentación y por las perturbaciones antropogénicas.

Hay distintas especies de invertebrados e vertebrados, venidos de los ambientes terrestres, marinos o de agua dulce. Se observó que muchas especies de la fauna vienen de otros hábitats y utilizan los manglares como un ecosistema de transición para otros ecosistemas adyacentes. Aunque hay también especies que permanecen durante todo su ciclo de vida. Los ecosistemas del entorno próximo a los manglares son la vegetación de restinga y la Selva Pluvial Tropical, además de la existencia de vegetación exótica, tal como los bosques de pinos y eucaliptos.

En el subcapítulo 3.3 SERVICIOS ECOSISTÉMICOS se han demostrado los múltiples 
beneficios que los manglares generan, tanto de regulación y abastecimiento, como culturales, siendo un ecosistema muy resistente y resiliente. Como punto fundamental para este estudio, están considerados como áreas altamente importantes respecto a la conectividad ecológica con la vegetación de entorno, pues proporcionan áreas de refugio y rica fuente de alimentación para una gran cantidad de la fauna que los utilizan durante la migración.

Sin embargo, se verificó una gran pérdida de su espacio por las actividades humanas a nivel mundial y nacional. De acuerdo con los análisis realizados en el subcapítulo 3.4 EL USO HUMANO Y LAS PÉRDIDAS AMBIENTALES, se constató una disminución de un 19\% aproximadamente en el mundo y un 4,8\% en Brasil entre 1980 y 2005 (FAO, 2007). Históricamente, en Brasil ha disminuido un $40 \%$ respecto al estado original y un $25 \%$ desde el inicio del siglo $\mathrm{XX}$, según los datos de $\mathrm{ICMBio}^{78}$, generando graves desequilibrios ecológicos.

Por otro lado, se ha identificado que, en las últimas décadas, la tasa de reducción de los manglares en la escala mundial y en Brasil ha disminuido. Se concluye, a partir de esto, que la conciencia del valor de este ecosistema costero viene mejorando gradualmente. Sin embargo se necesitan aún medidas y fiscalizaciones efectivas, además de esfuerzos para su restauración.

Los estudios de los paisajes de manglares respecto a la interrelación de los factores naturales y humanos a lo largo de la historia en la Región Metropolitana de Florianópolis constataron diversos impactos ambientales. Se han ocasionado por la ocupación inadecuada del entorno físico sin una fiscalización adecuada, principalmente por la práctica de la agricultura a partir de los mediados del siglo XVIII, seguido por la urbanización a partir de los mediados del siglo $\mathrm{XX}$, desarrollada en la sección 6.3.2 Histórico del uso del suelo.

De este modo, se han degradado las formaciones de los manglares de forma directa e indirecta, perjudicando la calidad de vida de la población, a través de la pérdida y fragmentación de la vegetación, la plantación de especies exóticas, la inundación, la contaminación del agua, aire y suelo, y el cambio climático. En la sección 6.3.3.7 Evaluación sobre los impactos ambientales, se comprobó que todos los impactos poseen el carácter permanente e irreversible a largo plazo. Aunque, con el uso de medidas protectoras y correctoras, vuelven recuperables a corto o medio plazo, con la excepción del cambio climático. Este último factor está considerado como un impacto extremo donde no hay una

78 ICMBio, Instituto Chico Mendes de conservação da biodiversidade. Disponible en http://www.icmbio.gov.br/ (fecha de consulta: febrero de 2017). 
medida correctora a corto o medio plazo, sino medidas paliativas para disminuir sus consecuencias.

Frente a los impactos producidos a lo largo del tiempo, se han llevado a cabo distintas figuras de protección ambiental. En el ámbito internacional (desarrollado en el subcapítulo 4.1 ÁMBITO INTERNACIONAL), los manglares de la Región Metropolitana de Florianópolis están incluidos en la lista de la Reserva de la Biosfera para la conservación de la Mata Atlántica, donde están constituidos una gran parte de los manglares de Brasil. Igualmente, en el evento Río+20 y Agenda 2030, se reconoció la importancia de la preservación y recuperación de los manglares, así como su uso sostenible.

Los manglares están delimitados en los Planes Directores de los municipios como Áreas de Preservación Permanente, protegidos y reglamentados a través de las leyes nacionales del Código Forestal y el Consejo Nacional del Medio Ambiente (Conama), respectivamente. A pesar de la protección destinada a estos manglares, se ha verificado en el subcapítulo 4.2 ÁMBITO NACIONAL, que podrán sufrir intervenciones para la construcción de obras habitacionales (si su función ecológica está comprometida) o de utilidad pública (como la infraestructura para el transporte, saneamiento y la acuicultura), lo que afectaría con gravedad al ecosistema y contribuiría a su degradación.

Algunos de los manglares también están protegidos por Unidades de Conservación con el objetivo de creación, implementación y gestión de áreas protegidas, además de la importancia de incluir corredores ecológicos entre las Unidades, como factor fundamental para el mantenimiento de la biodiversidad y la conservación de los servicios ecosistémicos. Sin embargo, solamente cuatro manglares están protegidos de los nueve existentes en el territorio metropolitano, demostrando la falta de compromiso y el descaso con el ambiente.

La caracterización espacial de los paisajes de manglares se ha realizado según los análisis de los nueve paisajes existentes en la Región Metropolitana de Florianópolis, desarrollada en el subcapítulo 6.4 CARACTERIZACIÓN ESPACIAL DE LOS PAISAJES DE MANGLARES. En este subcapítulo, se observó que hubo una disminución en la mayoría de los manglares entre los años de 1938 y 2015, donde la urbanización densa ha mostrado una tendencia a la devastación con resultados más destructivos de que la agricultura y la ganadería.

Tras el análisis temporal de los manglares, se caracterizaron especialmente los paisajes de forma cualitativa para el momento actual, mediante la elaboración de fichas de caracterización. En un aspecto general, se observó una discontinuidad de los espacios naturales debido a la perdida y fragmentación de los manglares, generado por el uso del suelo. 
Se constató que el paisaje de manglar menos afectado por la ocupación humana corresponde a Río Ratones, por estar mejor conectado con la vegetación próxima. Mientras que el más afectado se considera Itacorubi, a causa del aislamiento del manglar por la presencia de la urbanización. Este hecho es debido al vector de la expansión urbana, ocupando inicialmente las zonas más céntricas de los municipios de la Región Metropolitana (Itacorubi) en dirección a los sitios más al Norte y Sur (Río Ratones al Norte).

Finalmente, en el análisis de la percepción de la población para verificar el valor cultural de los paisajes de manglares de la Región Metropolitana de Florianópolis, realizado en el subcapítulo 6.5 PERCEPCIÓN DE LA POBLACIÓN, se verificó que hay un desconocimiento sobre el ecosistema. La relación personal de la población está únicamente vinculada con áreas de paso habitual u ocasional y casi nunca estancial. Existe una percepción sobre la importancia ecológica y la belleza visual de los manglares, pero, en general, no se relacionan con las actividades de pesca u ocio. Por otro lado, la población tiene la percepción sobre los impactos ambientales generados y considera que existe una necesidad hacia su preservación. Esto se considera un hecho importante, una vez que la población es responsable por las directrices para su gestión, protección y ordenación.

\subsection{CONECTIVIDAD ECOLÓGICA EN LOS PAISAJES DE MANGLARES}

La conectividad ecológica se basa en la importancia sostenible que generan las redes continuas naturales en diversas escalas y tipos de ecosistemas. Los estudios de la conectividad en el ecosistema de los manglares entre sí y con las otras vegetaciones circundantes son fundamentales por ser un área de transición en la migración de las especies venidas de otros ecosistemas.

Desde la perspectiva de la ecología del paisaje, desarrollada en el subcapítulo 5.2 ECOLOGÍA DEL PAISAJE Y CONECTIVIDAD, la conectividad ecológica ha dado un impulso respecto a los métodos para su medición en los aspectos estructurales y funcionales del paisaje, donde la forma del paisaje determina el comportamiento de las especies. En cuanto en la infraestructura verde (subcapítulo 5.3 INFRAESTRUCTURA VERDE Y CONECTIVIDAD), demuestra el potencial de lograr beneficios sostenibles a través de la conexión verde.

De acuerdo con el subcapítulo 5.5 CONTEXTO BRASILEÑO, se ha verificado que en Brasil hay una variedad de espacios ambientales. Sin embargo, no son suficientes para el mantenimiento de los los procesos ecosistémicos. Con esto, ha ocasionado la perdida y 
fragmentación natural, teniendo poco incentivo para la implementación y gestión de conexiones verdes en el territorio. A partir de los análisis en el ámbito nacional, así como en la Región Metropolitana de Florianópolis, se ha constatado la necesidad de alternativas sostenibles de conectividades ecológicas en diversas escalas territoriales.

En el capítulo 7 CONECTIVIDAD ECOLÓGICA EN LOS PAISAJES DE MANGLARES, se evaluó la conectividad ecológica basada en los principios de la ecología del paisaje, utilizando un nuevo método para la combinación de variadas métricas, a través del análisis del paisaje en el ámbito estructural y funcional. El estudio posibilitó la identificación de los fragmentos de hábitat más críticos para el mantenimiento de la conectividad en los paisajes de manglares. Se seleccionaron los paisajes menos y más afectados por la ocupación humana, como los de Río Ratones e Itacorubi, para la comparación de dos casos extremos de degradación, realizado en el subcapítulo 71. SELECCIÓN DE LOS CASOS DE ESTUDIO.

La utilización de la especie Lontra longicaudis en el método (subcapítulo 7.2 ESPECIE DE ESTUDIO) es bastante válida, una vez que está presente en ambientes acuáticos y terrestres, utilizándose tanto de los manglares como de la vegetación de entorno próximo como hábitat de supervivencia, además de estar amenazada de extinción, siendo un reto para su conservación. Sin embargo, sería adecuado complementar con otras especies de características de dispersión diferenciadas, además de especies de ambiente aéreo para una comparación más completa.

Se determinaron los valores de conectividad ecológica de cada fragmento de hábitat de los dos casos de estudio, con la utilización de diferentes métricas de conectividad de la Teoría de Grafos (subcapítulo 7.5 MÉTRICAS DE CONECTIVIDAD). Este método se ha utilizado en paisajes muy fragmentados, donde se posibilitó identificar las conexiones potenciales de la especie de estudio entre los fragmentos de hábitat (manglares y vegetación densa de entorno) a través de la permeabilidad del paisaje, como punto fundamental de análisis, desarrollados en los subcapítulos 7.3 PERMEABILIDAD DE PAISAJE y 7.4 CONEXIONES POTENCIALES.

Aunque hay una variedad de métricas que analizan diferentes aspectos en el paisaje, la construcción de una métrica única, mediante la combinación de un conjunto de métricas, produce un resultado de conectividad más generalista. Además, la normalización de las métricas entre 0 y 1 permite una evaluación concisa de la importancia de cada fragmento de hábitat, desde el menos conectado al más conectado.

De acuerdo con el subcapítulo 7.6 DIAGNÓSTICO, se ha identificado que en Río Ratones, de los 47 nodos existentes, 43 están considerados como más críticos. En cuanto a Itacorubi, de 
los 20 nodos, 16 están considerados como más críticos. Esta situación demuestra que una gran parte de los fragmentos de hábitat presentan riesgos ambientales, aumentando aún más las chances de pérdida y fragmentación de la vegetación. Se han verificado las siguientes características para los dos paisajes:

1. El tamaño reducido de área de los hábitats es perjudicial para la conectividad ecológica.

2. El valor de la conectividad de los fragmentos depende, además del área, de la ubicación espacial en el paisaje, diferenciándolos en los aspectos estructurales y funcionales.

3. En el aspecto estructural, los fragmentos más críticos están más aislados, ocupando espacios distantes de los otros nodos.

4. En el aspecto funcional, los fragmentos más críticos se sitúan donde predomina el uso urbano y las vías de carreteras, en lo que dificulta el movimiento de la especie de estudio entre los hábitats por su alto valor de resistencia en el paisaje.

Estas características están verificadas en los dos paisajes de manglares de estudio, pero de forma distinta, donde el uso del suelo en Río Ratones es más rural, e Itacorubi, más urbano. Aunque las áreas urbanas son más perturbadoras que las áreas rurales, pues, en la última, la vegetación puede regenerarse de forma natural con mayor facilidad.

De acuerdo con el estudio, se verificó que los manglares de ambos paisajes no están considerados como fragmentos de hábitat más críticos debido a su extensión de área y localización estructural/funcional, al contrario de la vegetación de su entorno próximo. Sin embargo, la conexión entre los ecosistemas es considerada fundamental para la conservación de los servicios ecosistémicos de los manglares.

En cuanto a las figuras de protección ambiental vigentes en los fragmentos de hábitats más críticos, en Río Ratones solamente un $\mathbf{2 6 , 5 2 \%}$ está protegido, mientras que en Itacorubi, apenas un $30,00 \%$ lo está. Como sugerencia, sería necesario la protección y restauración de todos los fragmentos más críticos, así como la protección y mantenimiento de los menos críticos, a partir de leyes ambientales adecuadas a este fin. Además, a través de los estudios de las conexiones potenciales se podrían delimitar otras áreas con vegetación nativa para crear una conexión entre los manglares y la vegetación adyacente. De esta forma, facilitaría el desplazamiento de la especie de estudio para mantener la diversidad biológica con el objetivo de proporcionar los servicios ecosistémicos de los manglares. 


\section{LÍNEAS DE INVESTIGACIONES FUTURAS}

La investigación actual se ha fundamentado en los análisis cualitativos y cuantitativos de la conectividad ecológica de los paisajes de manglares de la Región Metropolitana de Florianópolis para el momento presente, a través de los factores naturales y humanos, como resultado de su interrelación a lo largo de la historia. La comprensión histórica del desarrollo del territorio ha sido importante para el reconocimiento de los patrones del uso del suelo y su dinámica en el paisaje. Igualmente, los análisis sobre la percepción de la población han sido fundamentales para verificar el valor cultural de estos paisajes. Con todo, hay la necesidad de mejorar estos estudios con la utilización de un mayor número de encuestados, que represente de forma satisfactoria en relación al número poblacional total de habitantes de la Región Metropolitana.

Para obtener mejores resultados en los estudios cuantitativos de la conectividad ecológica, se propone una evaluación temporal a partir de las diferentes métricas de conectividades utilizadas en esta investigación, relacionándolas con las figuras de protección ambiental para cada periodo específico que se pretende analizar. Sin embargo, la dificultad encontrada en este análisis, y el principal motivo por el que la autora no pudo desarrollar la continuidad de este estudio, se debe a la falta de comprensión de las fotos aéreas existentes de la Región Metropolitana de Florianópolis, para los años 1938, 1956 y 1978, en relación a la delimitación de los tipos de vegetación y usos del suelo. Estas fechas son de extrema importancia, pues identifican las diferentes ocupaciones humanas que ocurrieron en el espacio metropolitano.

Además del análisis individual de cada momento histórico, sería importante efectuar un estudio comparativo de los fragmentos de hábitat en las diferentes épocas, de acuerdo con su progresión, reducción o desaparición, relacionándolos con los cambios del uso del suelo a lo largo del tiempo.

Respecto a las métricas, como cada una posee aspectos diferenciados, sería adecuado hacer una comparación entre ellas a través de los resultados de cada fragmento de hábitat en cada periodo, demostrando sus puntos débiles y fuertes. Para un resultado más completo, la adición de especies diferenciadas nativas terrestres y aéreas, es también de gran interés como líneas futuras de investigación.

Finalmente, la ampliación de la investigación para otras escalas mayores, que abarcan áreas de la Mata Atlántica es de gran importancia. Pues, según Dramstad et al. (1996, p. 47), citado 
PARTE IV. Capítulo 9. LÍNEAS DE INVESTIGACIONES FUTURAS

en el subcapítulo 5.2 ECOLOGÍA DEL PAISAJE Y CONECTIVIDAD, sólo se identifican los aspectos que estructuran un paisaje mediante los análisis en distintas escalas, para así poder maximizar la protección de la biodiversidad y los procesos naturales. 


\section{BIBLOGRAFÍAS}

Este capítulo presenta toda la bibliografía utilizada en el documento de la tesis a través de documentos escritos y referencias de internet, desarrollados en los subcapítulos subsecuentes:

10.1 DOCUMENTOS ESCRITOS

10.2 REFERENCIAS DE INTERNET 


\subsection{DOCUMENTOS ESCRITOS}

1. Adriaensen, F., Chardon, J. P., De Blust, G., Swinnen, E., Villalba, S., Gulinck, H., \& Matthysen, E. (2003). The application of 'least-cost'modelling as a functional landscape model. Landscape and urban planning, 64(4), 233-247.

2. Almeida, E. S. (2004). Geología da Ilha-SC. In: IPUF, Instituto de Planejamento Urbano De Florianópolis. Atlas do Município de Florianópolis. Florianópolis: Prefeitura Municipal.

3. Alongi, D. M. (2008). Mangrove forests: resilience, protection from tsunamis, and responses to global climate change. Estuarine, Coastal and Shelf Science, 76(1), 1-13;

4. Alves, J. R. P. (2001). Manguezais: educar para proteger. Rio de Janeiro: FEMAR/SEMADS.

5. Ayres, J. M., Fonseca, G. A. B., Rylands, A. B., Queiroz, H. L., Pinto, L. P., Masterson, D., \& Cavalcanti, R. B. (2005). Os corredores ecológicos das florestas tropicais do Brasil. Sociedade Civil Mamirauá (SCM).

6. Barattela, G. G., \& Menezes, J. T. (2011). Análise da variação da linha de costa do município de Biguaçu, SC. Anais XV Simpósio Brasileiro de Sensoriamento Remoto-SBSR.

7. Benedict, M. A., \& McMahon, E. D. (2006). Green Infrastructure. Linking Landscapes and Communities. Washington: Island Press.

8. Brasil (1986). Conselho Nacional do Meio Ambiente. Ministério do Meio Ambiente (Conama), Resolução $n^{\circ}$ 001/1986.

9. Brasil (1988). Constituição da República Federativa do Brasil, Brasília, Senado Federal. Párrafo $3^{\circ}$, Art. $25^{\circ}$.

10. Brasil (1988). Constituição da República Federativa do Brasil.

11. Brasil (1988). Lei $n^{\circ}$ 7.661. Institui o Plano Nacional de Gerenciamento Costeiro e dá outras providências.

12. Brasil (2000). Lei no 9.985. institui o Sistema Nacional de Unidades de Conservação da Natureza e dá outras providências.

13. Brasil (2001). Lei do Estatuto da Cidade $n^{0}$ 10.257. Regulamenta os arts. 182 e 183 da Constituição Federal, estabelece diretrizes gerais da política urbana e dá outras providências.

14. Brasil (2002). Conselho Nacional do Meio Ambiente. Ministério do Meio Ambiente (Conama), Resolução n 303/2002. Dispõe sobre parâmetros, defi nições e limites de Áreas de Preservação Permanente.

15. Brasil (2006). Conselho Nacional do Meio Ambiente. Ministério do Meio Ambiente (Conama), Resolução $n^{\circ} 369 / 2006$. Dispõe sobre os casos excepcionais, de utilidade pública, interesse social ou baixo impacto ambiental, que possibilitam a intervenção ou supressão de vegetação em Área de Preservação Permanente-APP.

16. Brasil (2012). Lei do Código Florestal n 12.651. Dispõe sobre a proteção da vegetação nativa.

17. Bueno, A. P. (2006). Patrimônio paisagístico e turismo na llha de Santa Catarina: a premência da paisagem no desenvolvimento sustentável da atividade turística. Tese (Doutorado), Faculdade de Arquitetura e Urbanismo, Universidade de São Paulo.

18. Bunn, A. G., Urban, D. L., \& Keitt, T. H. (2000). Landscape connectivity: a conservation application of graph theory. Journal of environmental management, 59(4), 265-278. 
19. Burel, F., \& Baudry, J. (1999). Écologie du paysage. Concepts, méthodes et applications. París: TEC \& DOC.

20. Cabral, O. R. (1970). História de Santa Catarina. Florianópolis: Laudes.

21. Caruso, M. M. L. (1981). Mapa de La Cobertura Vegetal de Isla de Santa Catarina-1978. 1:50.000. México, Universidad Nacional Autónoma de México.

22. Caruso, M. M. L. (1983). O desmatamento da llha de Santa Catarina de 1500 aos dias atuais. Florianópolis: UFSC.

23. CECCA, Centro de Estudos Cultura e Cidadania (1996). Uma cidade numa llha: relatório sobre os problemas sócio-ambientais da llha de Santa Catarina. Florianópolis: Insular.

24. CECCA, Centro de Estudos Cultura e Cidadania (1997). Unidades de Conservação e áreas protegidas da llha de Santa Catarina: Caracterização e Legislação. Florianópolis: Insular.

25. Chardon, J. P., Adriaensen, F., \& Matthysen, E. (2003). Incorporating landscape elements into a connectivity measure: a case study for the Speckled wood butterfly (Pararge aegeria L.). Landscape Ecology, 18(6), 561-573.

26. Chong Garduño, M. C. (2015). Expansión y transformación del territorio: la ineficiencia de los fraccionamientos urbanizados: zona conurbada de Veracruz, México. Tesis doctoral, Universidad Politécnica de Madrid.

27. Cintrón, G. \& Schaeffer-Novelli, Y. (1981). Los manglares de la costa brasileña: revisión preliminar de la literatura. Edición y revisión electrónica: Guilherme Moraes de Oliveira Abuchahla. [S. I]: Unesco, $47 \mathrm{f}$. Informe Técnico preparado para la Oficina Regional de Ciencia y Tecnología para América Latina y el Caribe de UNESCO y la Universidad Federal de Santa Catarina.

28. Cintrón, G., \& Schaeffer-Novelli, Y. (1981). Los manglares de la costa brasileña: revisión preliminar de la literatura. Departamento de Oceanografia Biológica.

29. Convenio Europeo del Paisaje (2000). Consejo de Europa (Florencia). Capítulo 1, Artículo 1.

30. Coura Neto, A. B., \& Klein, R. M. (1991). Mapeamento temático do município de Florianópolis. Florianópolis: IBGE, IPUF.

31. Cruz, O. A. (1998). Ilha de Santa Catarina e o continente próximo: um estudo da geomorfologia costeira. Florianópolis: UFSC.

32. Díaz-Palacios-Sisternes, S., Ayuga, F., \& García, A. I. (2014). A method for detecting and describing land use transformations: An examination of Madrid's southern urban-rural gradient between 1990 and 2006. Cities, 40, 99-110.

33. Dramstad, W. E., Olson, J. D., \& Forman, R. T. T. (1996) Landscape ecology principles in landscape architecture and land-use planning. Harvard University Graduate School of Design.

34. Doiron, S., \& Weissenberger, S. (2014). Sustainable dive tourism: Social and environmental impacts - The case of Roatan, Honduras. Tourism Management Perspectives, 10, 19-26.

35. EISMA, D. (1995). Climate Change Impact on Coastal Habitation. Texel, Netherlands: Lewis Publisher; Nobre, C. A. (2010). Mudanças climáticas globais: possíveis impactos nos ecossistemas do país. Parcerías estratégicas, 6(12), 239-258;

36. Epagri, Empresa de Pesquisa Agropecuária e Extensão Rural de Santa Catarina (2007). Mapa Digital das Unidades Hidrográficas do Estado de Santa Catarina.

37. Español Echániz, I. (2006). Manual de ecología del paisaje aplicada a la planificación urbana y de infraestructuras. Colegio de ingenieros de caminos, canales y puertos. 
38. Espírito Santo, S. M. (2004). Evolução da ocupação do solo nos manguezais do município de Palhoça utilizando técnicas de sensoriamento remoto. Dissertação de Mestrado, Programa de Pós Graduação em Engenharia Ambiental, Universidade Federal de Santa Catarina.

39. FAO, Food and Agriculture Organization of the United Nations (2007). The world's mangroves: 1980-2005. Roma: FAO Forest Paper.

40. Florianópolis (1955). Lei $n^{\circ} 246$, de 15 de novembro de 1955. Aprova o código municipal.

41. Florianópolis (1976). Lei $n^{\circ} 1440$, de 31 de maio de 1976. Altera o Plano Diretor da cidade e dá outras providências.

42. Florianópolis (2012). Lei Municipal $n^{\circ}$ 9.097. Institui a política municipal de remoção e substituição de pinus, eucalyptus e casuarina spp por espécies nativas no município de Florianópolis e dá outras providências.

43. Florianópolis (2014). Lei Complementar $n^{\circ} 482$. Institui o Plano Diretor de urbanismo do Município de Florianópolis que dispõe sobre a política de desenvolvimento urbano, o plano de uso e ocupação, os instrumentos urbanísticos e o sistema de gestão. Diário Oficial, Prefeitura Municipal de Florianópolis.

44. Forman, R. T. T., \& Godron, M. (1986). Landscape Ecology. Nueva York: Wiley and Sons.

45. Forman, R.T.T. (1995). Land Mosaics - The Ecology of Landscapes and Regions. Cambridge.

46. Fossari, T. D. (2004). A população pré-colonial Jê na paisagemda llha de Santa Catarina. Tese (Doutorado em Geografia), Programa de Pós- Graduação em Geografia, Universidade Federal de Santa Catarina.

47. Gallo-Reynoso, J. P. (1989). Distribución y estado actual de la nutria o perro de agua (Lutra longicaudis annectens Major, 1897) en la Sierra Madre del Sur, México. Tesis de maestría, Universidad Nacional Autónoma de México.

48. Gallo-Reynoso, J. P. (1997). Situación y distribución de las nutrias en México, con énfasis en Lontra longicaudis annectens Major, 1897. Revista Mexicana de Mastozoología, 2(1), 10-32.

49. Galpern, P., Manseau, M., \& Fall, A. (2011). Patch-based graphs of landscape connectivity: a guide to construction, analysis and application for conservation. Biological conservation, 144(1), 44-55.

50. Graipel, M. E., Cherem, J. J., \& Ximenez, A. (2001). Mamíferos terrestres não voadores da llha de Santa Catarina, no sul do Brasil. Biotemas, 14, 109-140.

51. Gunderson, L. H. (2000). Ecological resilience - in theory and application. Annual Review of Ecology and Systematics, 31, 425-439.

52. Hanski, I., \& Ovaskainen, O. (2000). The metapopulation capacity of a fragment landscape. Nature, 404(6779), 755-758.

53. Haro, M. A. P. de. (1979). Ilha de Santa Catarina: relatos de viajantes estrangeiros nos séculos XVIII e XIX. Florianópolis: UFSC, Lunardelli.

54. Hermann, M. L. de P. (2014). Atlas de Desastres Naturais do Estado de Santa Catarina: período de 1980 a 2010. Instituto Histórico e Geográfico de Santa Catarina, Cadernos Geográficos, Universidade Federal de Santa Catarina.

55. Hermann, M. L. de P., Kobiyama, N., \& Marcelino, E. V. (2014). Inundação Gradual. In: Atlas de Desastres Naturais do Estado de Santa Catarina: período de 1980 a 2010. Instituto Histórico e Geográfico de Santa Catarina, Cadernos Geográficos, Universidade Federal de Santa Catarina.

56. Herrmann, M. L. de P., \& Rosa, R. de O. (1991). Mapeamento temático do Município de 
Florianópolis - Geomorfologia. Florianópolis: IPUF/IBGE.

57. Higueras García, E. (2006). Urbanismo Bioclimático. Gustavo Gili.

58. Hogarth, P. J. (2007). The biology of mangroves and seagrasses. Oxford University Press.

59. Holling, C. S. (1986). The resilience of ecosystems: local surprise and global change. In: Sustainable development of the biosphere. Cambridge: Cambridge University Press, 292-397.

60. Holling, C. S., \& Gunderson, L. H. (2002). Resilience and Adaptive Cycles. In: Panarchy: understanding transformations in human and natural systems. Washington: Island Press, 1-49.

61. Howard, E. (1898). Garden Cities of To-Morrow. Faber \& Faber Limited.

62. Huber, M. V. (2004). Estudo comparativo de três projetos de restauração em áreas degradadas de manguezais da Grande Florianópolis. Dissertação de Mestrado em Engenharia Ambiental, Programa de Pós-Graduação em Engenharia Ambiental, Universidade Federal de Santa Catarina.

63. IBAMA, Instituto Brasileiro do Meio Ambiente e dos Recursos Naturais Renováveis (2003). Plano de manejo da Estação Ecológica de Carijós. Florianópolis: IBAMA.

64. IBAMA, Instituto Brasileiro do Meio Ambiente e dos Recursos Naturais Renováveis (1989). Portaria IBAMA n 1.522, de 19 de Dezembro de 1989.

65. IBGE, Índice Brasileiro de geografía e Estatística (2011). Atlas de Saneamento. Rio de Janeiro: IBGE.

66. Kathiresan, K., \& Bingham, B.L. (2001). Biology of Mangroves and Mangrove Ecosystems. Advances in Marine Biology, 40, 81-251.

67. Kindlmann, P., \& Burel, F. (2008). Connectivity measures: a review. Landscape ecology, 23(8), 879890.

68. Klein, R. M. (1969). Árvores nativas da ilha de Santa Catarina. INSULA Revista de Botânica, 3.

69. Klein, R. M. (1978). Mapa fitogeográfico do Estado de Santa Catarina. In: Reitz, R. Flora llustrada Catarinense. Itajaí: Herbário Barbosa Rodrigues.

70. Lamberti, A. (1969). Contribuição ao conhecimento da ecologia das plantas do manguezal de Itanhaém. Boletim da Faculdade de Filosofia, Ciências e Letras, Universidade de São Paulo, Botânica, 3-217.

71. Little, C. E. (1990). Greenways for America. Baltimore and London: The John Hopkins University Press,

72. Lopes, E. W. B. (1999). Ocupação humana em área de manguezal: o caso do manguezal de Palhoça. Dissertação (Mestrado em Geografia), Centro de Filosofia e Ciências Humanas, Universidade Federal de Santa Catarina.

73. Luiz, E. L. (2004). Relevo do Municipio de Florianópolis. In: IPUF, Instituto de Planejamento Urbano de Florianópolis. Atlas do Município de Florianópolis. Florianópolis: Prefeitura Municipal.

74. Luque, S., Saura, S., \& Fortin, M. J. (2012). Landscape connectivity analysis for conservation: insights from combining new methods with ecological and genetic data. Landscape Ecology, 27(2), 153-157.

75. Macedo, S. S. (2001). Produção da paisagem urbana contemporânea brasileira no final do século 20. Paisagem e Ambiente. 14, 143-170.

76. Macedo, S. S., \& Sakata, F. G. (2003). Parques Urbanos no Brasil. São Paulo: Edusp. 
77. Maller, C., Townsend, M., Pryor, A., Brown, P., \& St Leger, L. (2006). Healthy nature healthy people: 'contact with nature' as an upstream health promotion intervention for populations. Health promotion international, 21(1), 45-54.

78. Malvadkar, U., Scatena, F., \& Leon, M. (2015). A comparison of connectivity metrics on watersheds and implications for water management. River Research and Applications, 31(2), 256-267.

79. Marcelino, E. V., Goerl, R. F., Parizoto, D. G. V., Oliveira, C. A. F. de, \& Murara, P. G. (2014). Inundação Brusca. In: Atlas de Desastres Naturais do Estado de Santa Catarina: período de 1980 a 2010. Instituto Histórico e Geográfico de Santa Catarina, Cadernos Geográficos, Universidade Federal de Santa Catarina.

80. McHarg, I. (1969). Design with nature. New York: J. Wiley.

81. MCU-IPCE, Ministerio de Cultura-Instituto del Patrimonio Cultural de España (2012). Plan Nacional de Paisaje Cultural.

82. Nagelkerken, I., Blaber, S. J. M., Bouillon, S., Green, P., Haywood, M., Kirton, L. G., ... \& Somerfield, P. J. (2008). The habitat function of mangroves for terrestrial and marine fauna: a review. Aquatic Botany, 89(2), 155-185.

83. Naka, L. N., \& Rodrigues, M. (2000). As aves da llha de Santa Catarina. Florianópolis: UFSC.

84. Nascimento, M. V. (1989). Os manguezais da Ilha de Santa Catarina. $2^{\circ}$ Encontro Nacional de Estudos sobre Meio Ambiente, 1, 287-294.

85. Nimer, E. (1989). Climatologia do Brasil. Rio de Janeiro: IBGE. P. 260 y 261.

86. Nobre, C. A. (2010). Mudanças climáticas globais: possíveis impactos nos ecossistemas do país. Parcerías estratégicas, 6(12), 239-258.

87. Olimpio, J. (1990). Estratégias de preservação de lontras (Lutra longicaudis Olfers, 1818) (Mammalia, Mustelideae) na llha de Santa Catarina. I Encontro de Estudos Biológicos da UFSC, 6.

88. Pandolfo, C., Braga, H. J., Silva Júnior, V. P., Massignan, A. M., Pereira, E. S., Thomé, V. M. R., \& Valci, F. V. (2002). Atlas climatológico do Estado de Santa Catarina. Florianópolis: Epagri.

89. Pascual-Hortal, L., \& Saura, S. (2006). Comparison and development of new graph-based landscape connectivity indices: towards the priorization of habitat patches and corridors for conservation. Landscape ecology, 21(7), 959-967;

90. Pastor, G. C., \& Fuentes, D. S. (2009). Cruce de miradas. Visibilidad e invisibilidad del paisaje en territorios sujetos a usos turísticos. Cuadernos de Investigación Urbanística, 66.

91. Pattanaik, C., \& Prasad, S. N. (2011). Assessment of aquaculture impact on mangroves of Mahanadi delta (Orissa), East coast of India using remote sensing and GIS. Ocean \& coastal management, 54(11), 789-795.

92. Peel, M. C., Finlayson, B. L., \& McMahon, T. A. (2007). Updated world map of the Köppen-Geiger climate classification. Hydrology and earth system sciences discussions, 4(2), 439-473.

93. Pellegrino, P. R. M. (2003). Por uma paisagem fluvial para a São Paulo. Paisagens em Debate. Paisagem e Ambiente, 01.

94. Peluso Junior, V. A. (1991). Estudos de geografia urbana de Santa Catarina. Secretaria do Estado da Cultura e do Transporte, Editora da UFSC.

95. PMISB, Plano Municipal Integrado de Saneamento Básico (2010). Produto 2: Diagnóstico da caracterização física das unidades territoriais de análise e planejamento. Prefeitura Municipal de Florianópolis (PMF), Secretaria Municipal de Habitação e Saneamento Ambiental (SMHSA). 
96. Ramos, A. A. (1986). Memoria do saneamento Desterrense. Florianópolis: CASAN.

97. Rapport, D. J. (1995). Ecosystem health: More than a metaphor? Environmental Values, 287-309.

98. Reis, A. F. (2010). Crescimento Urbano-Turístico, Meio Ambiente e Urbanidade no Litoral Catarinense. I Encontro Nacional da Associação Nacional de Pesquisa e Pós-graduação em Arquitetura e Urbanismo, Rio de Janeiro.

99. Reis, A. F. (2010). Preservação ambiental no contexto urbano: cidade e natureza na llha de Santa Catarina. Revista Brasileira de Estudos Urbanos e Regionais, 12(1), 45-61.

100.Rheingantz, M., \& Trinca, C. (2015). Lontra longicaudis. The IUCN Red List of Threatened Species 2015, e.T12304A21937379. doi:10.2305/IUCN.UK.2015-2.RLTS.T12304A21937379.en.

101.Rizzo, P. M. B. (1993). Do urbanismo ao planejamento urbano: utopia e ideologia: o caso de Florianópolis, 1950 a 1990. Dissertação de Mestrado, Centro de Ciências Humanas, Universidade Federal de Santa Catarina.

102.Rudorff, F. de M., Bonetti Filho, J., Moreno, D. A., Oliveira, C. A. F. de, \& Murara, P. G. (2014). Inundação Brusca. In: Atlas de Desastres Naturais do Estado de Santa Catarina: período de 1980 a 2010. Instituto Histórico e Geográfico de Santa Catarina, Cadernos Geográficos, Universidade Federal de Santa Catarina.

103.Sabaté Bel, J. (2004). De la preservación del patrimonio a la ordenación del paisaje. Urbano, 7(10).

104.Saint-Hilaire, A. (1978). Viagem a Curitiba e Santa Catarina. São Paulo: Itatiaia, Universidade de São Paulo.

105.Sánchez Dalotto, R. A. (2003). Estruturação de dados como suporte à gestão de manguezais utilizando técnicas de geoprocessamento. Tese (Doutorado em Engenharia Civil), Curso de PósGraduação em Engenharia Civil, Universidade Federal de Santa Catarina.

106.Santa Catarina (1986). Atlas de Santa Catarina. GAPLAN, Gabinete de Planejamento e Coordenação Geral. Rio de Janeiro: Aerofoto Cruzeiro.

107.Santa Catarina (1991). Atlas escolar de Santa Catarina. Secretaria de Estado de Coordenação Geral e Planejamento e Subsecretaria de Estudos Geográficos e Estatísticos. Rio de Janeiro: Aerofoto Cruzeiro.

108.Santa Catarina (2014). Atlas Geográfico de Santa Catarina. Diversidade da Natureza/Fascículo 2. Secretaria de Estado do Planejamento. Florianópolis: UDESC.

109.Santa Catarina (1994). Lei Complementar no 104. Dispõe sobre os princípios da regionalização do Estado e adota outras providências.

110.Santa Catarina (1998). Lei Complementar $n^{\circ}$ 162. Institui as Regiões Metropolitanas de Florianópolis, do Vale do Itajaí e do Norte/Nordeste Catarinense e estabelece outras providências.

111.Santa Catarina (2007). Lei Complementar $n^{\circ} 381$. Dispõe sobre o modelo de gestão e a estrutura organizacional da administração pública Estadual.

112.Santa Catarina (2010). Lei Complementar $\mathrm{n}^{\circ}$ 495. Institui as Regiões Metropolitanas de Florianópolis, do Vale do Itajaí, do Norte/Nordeste Catarinense, de Lages, da Foz do Rio Itajaí, Carbonífera e de Tubarão.

113.Santa Catarina (2016). Lista comentada de espécies exóticas invasoras no estado de Santa Catarina: espécies que ameaçam a diversidade biológica. Florianópolis: FATMA.

114.Santos, A. L. G. dos (2014). Cartografia dos níveis hierárquicos dos manguezais: uma visão sistémica. Tese de Doutorado, Universidade de São Paulo (USP). 
115.Santos, S. C. (1977). Nova Historia de Santa Catarina. Florianópolis.

116.SAR, Secretaria de Agricultura e Abastecimento do Estado de Santa Catarina (2005). Inventário Florístico Florestal de Santa Catarina. Relatório do Projeto Piloto. Florianópolis.

117.Sauer, C. O. (1925). The morphology of landscape. University of California Publications in Geography, 2, 19-53.

118.Saura, S., \& Pascual-Hortal, L. (2007). A new habitat availability index to integrate connectivity in landscape conservation planning: comparison with existing indices and application to a case study. Landscape and Urban Planning, 83(2), 91-103.

119.Saura, S., \& Torne, J. (2009). Conefor Sensinode 2.2: a software package for quantifying the importance of habitat patches for landscape connectivity. Environmental Modelling \& Software, 24(1), 135-139.

120.Schaeffer-Novelli, Y., Cintrón-Molero, G. Y., \& Adaime, R. R. (1990). Variability of mangrove ecosystems along the brazilian coast. Estuar, 13(2), 204-218.

121.Sevegnani, L., \& Schroeder, E. (2013). Biodiversidade Catarinense: características, potencialidades, ameaças. Blumenau: Edifurb.

122.Silva, A. D. (1990). Estudo geo-estrutural do manguezal de Ratones na llha de Santa Catarina: município de Florianópolis-SC. Dissertação (Mestrado), Centro de Ciências Humanas, Universidade Federal de Santa Catarina.

123. Silva, A. de F. (2011). Jardins históricos brasileiros e mexicanos. Interlocuções sobre histografia e preservação. Vitrúvius, 111.01, año 10.

124.SNIS, Sistema Nacional de Informações Sobre Saneamento (2011). Diagnósticos dos Serviços de Água e Esgoto. Secretaria Nacional de Saneamento Ambiental, Ministério das Cidades.

125.Sommer, S., \& Rosatelli, J. (1991). Mapeamento temático do município de Florianópolis-Mapa de solos. Síntese temática. Florianópolis: IPUF/IBGE.

126.Souza Sobrinho, R. J. de (1972). Agricultura na Ilha de Santa Catarina no Brasil Colônia. INSULA Revista de Botânica, 5.

127.Souza Sobrinho, R. J. de, Bresolin, A., \& Klein, R. M. (1969). Os manguezais na ilha de Santa Catarina. INSULA Revista de Botânica, 2.

128.Spalding, M.S., Kainuma, M., \& Collins, L. (2010). World atlas of mangroves. London: Earthscan.

129.Taylor, P. D., Fahrig, L., Henein, K., \& Merriam, G. (1993). Connectivity is a vital element of landscape structure. Oikos, 571-573.

130.Terra, C. G. (2000). O Jardim no Brasil no Século XIX. Glaziou Revisitado. Rio de Janeiro: EBA/UFRJ.

131.Trindade, L. C. (2009). Os manguezais da llha de Santa Catarina frente à antropização da paisagem. Dissertação de Mestrado, Programa de Pós-Graduação em Arquitetura e Urbanismo, Universidade Federal de Santa Catarina.

132. Unión Europea (1997). Directiva 97/11/CE del Consejo de 3 de marzo de 1997, por la que se modifica la Directiva 85/337/CEE relativa a la evaluación de las repercusiones de determinados proyectos públicos y privados sobre el medio ambiente.

133. Unión Europea (2013). Comunicación de la comisión al parlamento europeo, al consejo, al comité económico y social europeo y al comité de las regiones. Infraestructura verde: mejora del capital natural de Europa. Bruselas. 
134.Urban, D. L., Minor, E. S., Treml, E. A., \& Schick, R. S. (2009). Graph models of habitat mosaics. Ecology letters, 12(3), 260-273.

135.Urban, D., \& Keitt, T. (2001). Landscape connectivity: a graph-theoretic perspective. Ecology, 82(5), 1205-1218.

136.Várzea, V. (1984). Santa Catarina - A Ilha. Florianópolis: IOESC.

137.Veiga, E. V. (1993). Florianópolis: memória urbana. Florianópolis: UFSC, Fundação Franklin Cascaes.

138.Vieira da Rosa, J. (1905). Chorographia de Santa Catharina. Florianópolis: Typ. da Livraria Moderna.

139.Vilà, M., Espinar, J. L., Hejda, M., Hulme, P. E., Jarošík, V., Maron, J. L., .. \& Pyšek, P. (2011). Ecological impacts of invasive alien plants: a meta-analysis of their effects on species, communities and ecosystems. Ecology letters, 14(7), 702-708.

140.Walsh, G .E. (1974). Mangroves: a review. In: Reinhold RJ, Queen W.H, eds. Ecology of halophytes. New York: Academic Press, 51-174.

141.Xin, K., Huang, X., Hu, J., Li, C., Yang, X., \& Arndt, S. K. (2014). Land use change impacts on heavy metal sedimentation in mangrove wetlands - a case study in Dongzhai Harbor of Hainan, China. Wetlands, 34(1), 1-8.

142.Zeller, K. A., McGarigal, K., \& Whiteley, A. R. (2012). Estimating landscape resistance to movement: a review. Landscape Ecology, 27(6), 777-797. 


\subsection{REFERENCIAS DE INTERNET}

1. Agenda 2030 para el Desarrollo Sostenible. Resolución aprobada por la Asamblea General el 25 de septiembre de 2015. Disponible en http://www.un.org/es/comun/docs/?symbol=A/RES/70/1 (fecha de consulta: junio de 2018).

2. Apremavi, Associação de preservação do meio ambiente e da vida. Disponible en http://www.apremavi.org.br/ (fecha de consulta: julio de 2016)

3. CE, Comisión Europea (2014). Construir una infraestructura verde para Europa. Luxemburgo: Oficina de Publicaciones Oficiales de la Unión Europea. Disponible en http://ec.europa.eu/environment/nature/ecosystems/docs/GI-Brochure-210x210-ES-web.pdf (fecha de consulta: marzo de 2015).

4. CPTEC-INPE, Centro de Previsão de Tempo e Estudos Climáticos e Instituto Nacional de Pesquisas Espaciais. Disponible en http://enos.cptec.inpe.br/elnino/pt (fecha de consulta: junio de 2016).

5. CIRAM, Centro de Informação de Recursos Ambientais e de Hidrometeorologia de Santa Catarina (2005). Disponible en http://ciram.epagri.sc.gov.br/ (fecha de consulta: enero de 2016).

6. Embrapa, Empresa Brasileira de Pesquisa Agropecuária. Disponible en http://www.agencia.cnptia.embrapa.br/ (fecha de consulta: junio de 2018).

7. Emerald Necklace. Disponible en http://www.emeraldnecklace.org/ (fecha de consulta: marzo de 2015).

8. Fariña, J. T. (2000) Naturaleza urbana. Ciudades para un futuro más sostenible. Disponible en http://habitat.aq.upm.es/boletin/n15/ajfar.html (fecha de consulta: enero de 2018).

9. Fariña, J. (2013) Servicios de los ecosistemas. Disponible en https://elblogdefarina.blogspot.com.br/2013/01/servicios-de-los-ecosistemas.html (fecha de consulta: mayo de 2018).

10. IBGE, Índice Brasileiro de Geografia e Estatística. Disponible en http://www.cidades.ibge.gov.br/ (fecha de consulta: diciembre de 2017).

11. IBGE, Instituto Brasileiro de Geografia e Estatística (2014). Estimativas da população dos municípios brasileiros com data de referência em $1^{\circ}$ de julho de 2014. Disponible en http://www.ibge.gov.br/home/presidencia/noticias/pdf/analise_estimativas_2014.pdf (fecha de consulta: diciembre de 2015).

12. ICMBio, Instituto Chico Mendes de conservação da biodiversidade. Disponible en http://www.icmbio.gov.br/ (fecha de consulta: febrero de 2017).

13. IHU, Instituto Humanistas Unisinos. Disponible en http://www.ihu.unisinos.br/ (fecha de consulta: junio de 2016).

14. Mapas digitales. Disponible en http://ciram.epagri.sc.gov.br (fecha de consulta: abril de 2016).

15. Newsweek. Disponible en http://www.newsweek.com/id/46125/page/12 (fecha de consulta: abril de 2015).

16. NOAA, National Oceanic and Atmospheric Administration. Disponible en http://www.nhc.noaa.gov/aboutsshws.php (fecha de consulta: septiembre de 2016).

17. PNUD, Programa de Desarrollo de las Naciones Unidas. Disponible en http://www.pnud.org.br/atlas/ranking/Ranking-IDHM-Municipios-2010.aspx (fecha de consulta: abril 
de 2015).

18. Río+20, Conferencia de las Naciones Unidas sobre el Desarrollo Sostenible. Documento final. Disponible en https://rio20.un.org/sites/rio20.un.org/files/a-conf.216-I-1_spanish.pdf.pdf (fecha de consulta: marzo de 2018).

19. Tablas de Mareas. Disponible en http://www.mar.mil.br/dhn/chm/box-previsao-mare/tabuas/ (fecha de consulta: junio de 2016).

20. The New York Times. Disponible en http://www.nytimes.com/2009/01/11/travel/11party.html?_r=1\& (fecha de consulta: abril de 2015).

21. UNESCO, Organización de las Naciones Unidas para la Educación, la Ciencia y la Cultura. Disponible en: http://www.unesco.org (fecha de consulta: marzo de 2018).

22. UNRIC, United Nations Regional Information Centre for Western Europe. Disponible en http://www.unric.org/pt/actualidade/ (fecha de consulta: noviembre de 2015).

23. UOL Notícias. Disponible en https://noticias.uol.com.br/ (fecha de consulta: enero de 2018). 


\section{ANEXOS}

Los anexos que complementaron esta investigación están desarrollados en los subcapítulos subsecuentes:

11.1 ÁREAS DE LOS FRAGMENTOS DE HÁBITATS

11.2 CONEXIONES POTENCIALES EN RÍO RATONES

11.3 CONEXIONES POTENCIALES EN ITACORUBI

11.4 CÓDIGOS REGENERADO EN EL MATLAB

11.5 VALORES DE LOS NODOS PARA CADA MÉTRICA DE CONECTIVIDAD ECOLÓGICA EN RÍO RATONES

11.6 VALORES DE LOS NODOS PARA CADA MÉTRICA DE CONECTIVIDAD ECOLÓGICA EN ITACORUBI

11.8 VALORES NORMALIZADOS DE LOS NODOS (ENTRE 0 Y 1) PARA CADA MÉTRICA DE CONECTIVIDAD ECOLÓGICA EN RÍO RATONES

11.8 VALORES NORMALIZADOS DE LOS NODOS (ENTRE 0 Y 1) PARA CADA MÉTRICA DE CONECTIVIDAD ECOLÓGICA EN ITACORUBI

11.9 PROMEDIOS DE LOS VALORES NORMALIZADOS POR NODO

11.10 VALORES NORMALIZADOS (ENTRE 0 Y 1) DE LOS PROMEDIOS POR NODO

11.11 ÁREAS DE PROTECCIÓN AMBIENTAL POR NODO (MÁS CRÍTICOS) DE RÍO RATONES

11.12 ÁREAS DE PROTECCIÓN AMBIENTAL POR NODO (MÁS CRÍTICOS) DE ITACORUBI 


\section{1 ÁREAS DE LOS FRAGMENTOS DE HÁBITATS}

\begin{tabular}{|c|c|c|c|c|c|}
\hline \multicolumn{4}{|c|}{ Río Ratones } & \multicolumn{2}{|c|}{ Itacorubi } \\
\hline Nodo & Área m² & Nodo & Área $\mathrm{m}^{2}$ & Nodo & Área m² \\
\hline 1 & $754.682,02$ & 26 & $75.549,41$ & 1 & $1.452 .863,63$ \\
\hline 2 & $1.962 .161,66$ & 27 & $490.124,35$ & 2 & $20.127,58$ \\
\hline 3 & $760.862,76$ & 28 & $11.368 .239,83$ & 3 & $125.643,55$ \\
\hline 4 & $167.995,99$ & 29 & $2.751 .708,50$ & 4 & $208.653,95$ \\
\hline 5 & $92.842,30$ & 30 & $120.210,78$ & 5 & $26.876,40$ \\
\hline 6 & $246.701,96$ & $31 a$ & $13.494 .636,43$ & 6 & $35.611,82$ \\
\hline 7 & $70.344,14$ & $31 b$ & $8.743 .623,42$ & 7 & $26.889,73$ \\
\hline 8 & $249.126,79$ & $31 c$ & $14.236 .690,76$ & 8 & $52.352,17$ \\
\hline 9 & $120.782,05$ & 32 & $29.148,96$ & 9 & $28.907,91$ \\
\hline 10 & $185.502,73$ & 33 & $67.572,36$ & 10 & $21.733,44$ \\
\hline 11 & $37.390,31$ & 34 & $153.296,79$ & 11 & $15.864,15$ \\
\hline 12 & $231.302,47$ & 35 & $193.573,28$ & 12 & $15.030,04$ \\
\hline 13 & $166.760,82$ & 36 & $195.900,90$ & 13 & $11.449,81$ \\
\hline 14 & $125.385,72$ & 37 & $31.073,91$ & 14 & $38.153,70$ \\
\hline 15 & $166.828,81$ & 38 & $66.735,25$ & 15 & $106.207,31$ \\
\hline 16 & $29.210,96$ & 39 & $256.198,79$ & 16 & $565.820,41$ \\
\hline 17 & $202.152,59$ & 40 & $31.563,59$ & 17 & $558.498,26$ \\
\hline 18 & $79.192,76$ & 41 & $838.334,33$ & 18 & $6.642 .494,33$ \\
\hline 19 & $75.727,50$ & 42 & $2.028 .709,48$ & 19 & $106.395,59$ \\
\hline 20 & $266.094,12$ & 43 & $52.247,08$ & 20 & $5.403 .510,11$ \\
\hline 21 & $22.535,33$ & 44 & $32.566,61$ & & \\
\hline 22 & $95.240,13$ & 45 & $2.900 .272,97$ & & \\
\hline 23 & $90.376,68$ & 46 & $625.684,52$ & & \\
\hline 24 & $38.314,62$ & 47 & $51.419,78$ & & \\
\hline 25 & $337.870,78$ & & & & \\
\hline
\end{tabular}

Tabla 11.1: Áreas de los fragmentos de hábitats. Fuente: Elaboración propia. 


\subsection{CONEXIONES POTENCIALES EN RÍO RATONES}

\begin{tabular}{|c|c|c|c|c|c|c|c|c|}
\hline \multicolumn{2}{|c|}{ Nodo } & \multirow{2}{*}{$\begin{array}{c}\text { Enlace } \\
14.357,90\end{array}$} & \multicolumn{2}{|c|}{ Nodo } & \multirow{2}{*}{$\begin{array}{c}\text { Enlace } \\
13.287,03\end{array}$} & \multicolumn{2}{|c|}{ Nodo } & \multirow{2}{*}{$\begin{array}{c}\text { Enlace } \\
56.276,29 \\
\end{array}$} \\
\hline 1 & 2 & & 3 & 4 & & 5 & 10 & \\
\hline 1 & 3 & $31.556,43$ & 3 & 5 & $34.645,14$ & 5 & 11 & $55.552,32$ \\
\hline 1 & 4 & $44.585,27$ & 3 & 6 & $47.058,53$ & 5 & 12 & $57.392,78$ \\
\hline 1 & 5 & $3.828 .614,00$ & 3 & 7 & $64.124,13$ & 5 & 13 & $52.803,23$ \\
\hline 1 & 6 & $31.787,00$ & 3 & 8 & $56.107,58$ & 5 & 14 & $51.686,84$ \\
\hline 1 & 7 & $86.659,84$ & 3 & 9 & $54.205,24$ & 5 & 15 & $77.813,80$ \\
\hline 1 & 8 & $76.044,49$ & 3 & 10 & $77.090,63$ & 5 & 16 & $4.943 .642,00$ \\
\hline 1 & 9 & $74.171,45$ & 3 & 11 & $76.211,12$ & 5 & 17 & $19.336,90$ \\
\hline 1 & 10 & $52.538,46$ & 3 & 12 & $74.600,34$ & 5 & 18 & $24.871,79$ \\
\hline 1 & 11 & $51.814,48$ & 3 & 13 & $79.313,30$ & 5 & 19 & $33.095,44$ \\
\hline 1 & 12 & $53.654,95$ & 3 & 14 & $43.886,56$ & 5 & 20 & $36.751,37$ \\
\hline 1 & 13 & $49.065,40$ & 3 & 15 & $70.904,41$ & 6 & 7 & $82.955,48$ \\
\hline 1 & 14 & $48.066,36$ & 3 & 16 & $32.757,70$ & 6 & 8 & $89.559,96$ \\
\hline 1 & 15 & $74.075,95$ & 3 & 17 & $47.164,82$ & 6 & 9 & $87.657,62$ \\
\hline 1 & 16 & $1.309,03$ & 3 & 18 & $43.094,25$ & 6 & 10 & $84.234,44$ \\
\hline 1 & 17 & $15.716,22$ & 3 & 19 & $60.923,48$ & 6 & 11 & $83.510,47$ \\
\hline 1 & 18 & $21.251,12$ & 3 & 20 & $31.647,61$ & 6 & 12 & $85.350,94$ \\
\hline 1 & 19 & $29.474,78$ & 4 & 5 & $45.490,00$ & 6 & 13 & $80.761,41$ \\
\hline 1 & 20 & $33.131,14$ & 4 & 6 & $33.804,64$ & 6 & 14 & $31.484,11$ \\
\hline 2 & 3 & $45.914,35$ & 4 & 7 & $77.317,44$ & 6 & 15 & $104.356,80$ \\
\hline 2 & 4 & $42.169,23$ & 4 & 8 & $69.300,88$ & 6 & 16 & $32.901,84$ \\
\hline 2 & 5 & $17.680,36$ & 4 & 9 & $67.398,54$ & 6 & 17 & $31.318,30$ \\
\hline 2 & 6 & $36.685,91$ & 4 & 10 & $90.283,93$ & 6 & 18 & $24.357,65$ \\
\hline 2 & 7 & $90.963,07$ & 4 & 11 & $89.404,41$ & 6 & 19 & $45.584,70$ \\
\hline 2 & 8 & $89.932,47$ & 4 & 12 & $87.793,63$ & 6 & 20 & $18.228,90$ \\
\hline 2 & 9 & $88.059,42$ & 4 & 13 & $92.506,59$ & 7 & 8 & $10.712,47$ \\
\hline 2 & 10 & $66.426,42$ & 4 & 14 & $30.632,67$ & 7 & 9 & $12.517,90$ \\
\hline 2 & 11 & $65.702,45$ & 4 & 15 & $84.097,76$ & 7 & 10 & $35.736,79$ \\
\hline 2 & 12 & $67.542,92$ & 4 & 16 & $45.786,59$ & 7 & 11 & $34.857,27$ \\
\hline 2 & 13 & $62.953,37$ & 4 & 17 & $36.801,21$ & 7 & 12 & $33.246,49$ \\
\hline 2 & 14 & $39.143,66$ & 4 & 18 & $29.840,97$ & 7 & 13 & $37.959,47$ \\
\hline 2 & 15 & $87.963,99$ & 4 & 19 & $51.067,48$ & 7 & 14 & $75.454,72$ \\
\hline 2 & 16 & $14.991,30$ & 4 & 20 & $18.393,73$ & 7 & 15 & $25.232,09$ \\
\hline 2 & 17 & $11.557,66$ & 5 & 6 & $27.958,39$ & 7 & 16 & $85.729,26$ \\
\hline 2 & 18 & $12.949,16$ & 5 & 7 & $90.397,68$ & 7 & 17 & $85.593,79$ \\
\hline 2 & 19 & $25.824,11$ & 5 & 8 & $79.782,33$ & 7 & 18 & $78.633,98$ \\
\hline 2 & 20 & $24.208,21$ & 5 & 9 & $77.909,28$ & 7 & 19 & $99.860,07$ \\
\hline
\end{tabular}

Continua... 


\begin{tabular}{|c|c|c|c|c|c|c|c|c|}
\hline \multicolumn{2}{|c|}{ Nodo } & \multirow{2}{*}{$\begin{array}{c}\text { Enlace } \\
46.043,14\end{array}$} & \multicolumn{2}{|c|}{ Nodo } & \multirow{2}{*}{$\begin{array}{c}\text { Enlace } \\
35.398,83\end{array}$} & \multicolumn{2}{|c|}{ Nodo } & \multirow{2}{*}{$\begin{array}{c}\text { Enlace } \\
26.978,25\end{array}$} \\
\hline 3 & 20 & & 4 & 12 & & 4 & $31 b$ & \\
\hline 3 & 21 & $47.648,50$ & 4 & 13 & $37.717,44$ & 5 & 6 & $36.686,89$ \\
\hline 3 & 22 & $52.696,84$ & 4 & 14 & $23.923,09$ & 5 & 7 & $33.305,66$ \\
\hline 3 & 23 & $50.195,82$ & 4 & 15 & $40.305,32$ & 5 & 8 & $37.846,21$ \\
\hline 3 & 24 & $44.975,07$ & 4 & 16 & $48.875,10$ & 5 & 9 & $39.624,14$ \\
\hline 3 & 25 & $47.060,05$ & 4 & 17 & $39.927,67$ & 5 & 10 & $36.638,55$ \\
\hline 3 & 26 & $51.458,31$ & 4 & 18 & $20.847,01$ & 5 & 11 & $25.293,15$ \\
\hline 3 & 27 & $48.407,19$ & 4 & 19 & $24.110,18$ & 5 & 12 & $33.458,02$ \\
\hline 3 & 28 & $42.699,83$ & 4 & 20 & $35.742,66$ & 5 & 13 & $35.776,63$ \\
\hline 3 & 29 & $39.755,69$ & 4 & 21 & $34.014,25$ & 5 & 14 & $24.498,15$ \\
\hline 3 & 30 & $36.629,13$ & 4 & 22 & $39.018,25$ & 5 & 15 & $38.364,50$ \\
\hline 3 & $31 a$ & $37.270,56$ & 4 & 23 & $42.447,31$ & 5 & 16 & $46.934,28$ \\
\hline 3 & 32 & $38.982,97$ & 4 & 24 & $37.052,65$ & 5 & 17 & $37.986,85$ \\
\hline 3 & 33 & $39.185,85$ & 4 & 25 & $39.460,60$ & 5 & 18 & $18.906,20$ \\
\hline 3 & 34 & $11.318,01$ & 4 & 26 & $43.858,86$ & 5 & 19 & $22.169,37$ \\
\hline 3 & 35 & $8.514 .732,00$ & 4 & 27 & $41.615,81$ & 5 & 20 & $33.801,84$ \\
\hline 3 & 36 & $51.163,88$ & 4 & 28 & $34.951,32$ & 5 & 21 & $32.073,44$ \\
\hline 3 & 37 & $38.109,19$ & 4 & 29 & $34.407,65$ & 5 & 22 & $37.077,53$ \\
\hline 3 & 38 & $6.746 .546,00$ & 4 & 30 & $48.377,75$ & 5 & 23 & $40.506,49$ \\
\hline 3 & 39 & $49.132,54$ & 4 & $31 a$ & $15.928,79$ & 5 & 24 & $35.111,86$ \\
\hline 3 & 40 & $45.605,55$ & 4 & 32 & $36.380,32$ & 5 & 25 & $37.519,78$ \\
\hline 3 & 41 & $37.137,16$ & 4 & 33 & $37.993,34$ & 5 & 26 & $41.918,04$ \\
\hline 3 & 42 & $5.278 .041,00$ & 4 & 34 & $23.140,91$ & 5 & 27 & $39.674,99$ \\
\hline 3 & 43 & $53.811,47$ & 4 & 35 & $20.248,20$ & 5 & 28 & $33.010,50$ \\
\hline 3 & 44 & $52.176,28$ & 4 & 36 & $29.764,78$ & 5 & 29 & $32.466,83$ \\
\hline 3 & 45 & $44.053,70$ & 4 & 37 & $19.718,55$ & 5 & 30 & $46.800,41$ \\
\hline 3 & 46 & $53.367,84$ & 4 & 38 & $30.589,98$ & 5 & $31 a$ & $13.987,97$ \\
\hline 3 & 47 & $53.655,80$ & 4 & 39 & $28.850,01$ & 5 & 32 & $34.439,50$ \\
\hline 3 & $31 c$ & $51.810,04$ & 4 & 40 & $35.913,41$ & 5 & 33 & $36.052,52$ \\
\hline 3 & $31 b$ & $48.153,61$ & 4 & 41 & $38.266,27$ & 5 & 34 & $25.753,82$ \\
\hline 4 & 5 & $5.056 .081,00$ & 4 & 42 & $19.208,71$ & 5 & 35 & $22.861,10$ \\
\hline 4 & 6 & $38.627,71$ & 4 & 43 & $43.039,84$ & 5 & 36 & $27.823,96$ \\
\hline 4 & 7 & $35.246,48$ & 4 & 44 & $41.404,64$ & 5 & 37 & $17.961,13$ \\
\hline 4 & 8 & $39.787,04$ & 4 & 45 & $30.715,81$ & 5 & 38 & $33.430,44$ \\
\hline 4 & 9 & $41.564,96$ & 4 & 46 & $32.657,66$ & 5 & 39 & $26.909,19$ \\
\hline 4 & 10 & $38.579,22$ & 4 & 47 & $32.945,63$ & 5 & 40 & $33.972,63$ \\
\hline 4 & 11 & $27.233,96$ & 4 & $31 c$ & $37.152,28$ & 5 & 41 & $36.325,48$ \\
\hline
\end{tabular}

Continua... 


\begin{tabular}{|c|c|c|c|c|c|c|c|c|}
\hline \multicolumn{2}{|c|}{ Nodo } & \multirow{2}{*}{$\begin{array}{c}\text { Enlace } \\
21.821,61 \\
\end{array}$} & \multicolumn{2}{|c|}{ Nodo } & \multirow{2}{*}{$\begin{array}{c}\text { Enlace } \\
21.183,68 \\
\end{array}$} & \multicolumn{2}{|c|}{ Nodo } & \multirow{2}{*}{$\begin{array}{c}\text { Enlace } \\
19.376,01\end{array}$} \\
\hline 5 & 42 & & 6 & 36 & & 7 & $31 a$ & \\
\hline 5 & 43 & $41.099,18$ & 6 & 37 & $32.492,42$ & 7 & 32 & $8.402 .402,00$ \\
\hline 5 & 44 & $39.463,98$ & 6 & 38 & $47.877,13$ & 7 & 33 & $10.027,13$ \\
\hline 5 & 45 & $28.774,99$ & 6 & 39 & $13.606,66$ & 7 & 34 & $35.479,14$ \\
\hline 5 & 46 & $30.716,84$ & 6 & 40 & $10.067,57$ & 7 & 35 & $37.796,72$ \\
\hline 5 & 47 & $31.004,83$ & 6 & 41 & $5.341 .558,00$ & 7 & 36 & $20.332,67$ \\
\hline 5 & $31 \mathrm{c}$ & $35.211,56$ & 6 & 42 & $35.952,55$ & 7 & 37 & $29.110,74$ \\
\hline 5 & $31 \mathrm{~b}$ & $25.037,43$ & 6 & 43 & $18.273,93$ & 7 & 38 & $52.834,91$ \\
\hline 6 & 7 & $10.649,84$ & 6 & 44 & $16.638,71$ & 7 & 39 & $10.224,96$ \\
\hline 6 & 8 & $15.190,41$ & 6 & 45 & $8.527 .535,00$ & 7 & 40 & $7.149,57$ \\
\hline 6 & 9 & $19.673,08$ & 6 & 46 & $17.842,17$ & 7 & 41 & $10.299,42$ \\
\hline 6 & 10 & $22.096,04$ & 6 & 47 & $18.130,16$ & 7 & 42 & $40.910,34$ \\
\hline 6 & 11 & $12.312,38$ & 6 & $31 \mathrm{c}$ & $16.272,30$ & 7 & 43 & $12.872,71$ \\
\hline 6 & 12 & $14.734,88$ & 6 & $31 \mathrm{~b}$ & $16.394,45$ & 7 & 44 & $11.237,48$ \\
\hline 6 & 13 & $13.865,12$ & 7 & 8 & $4.585 .563,00$ & 7 & 45 & $5.145 .845,00$ \\
\hline 6 & 14 & $40.465,72$ & 7 & 9 & $10.885,47$ & 7 & 46 & $13.867,13$ \\
\hline 6 & 15 & $7.381 .465,00$ & 7 & 10 & $15.201,51$ & 7 & 47 & $14.748,46$ \\
\hline 6 & 16 & $24.507,49$ & 7 & 11 & $8.930,68$ & 7 & $31 \mathrm{c}$ & $10.040,91$ \\
\hline 6 & 17 & $17.138,60$ & 7 & 12 & $11.353,19$ & 7 & $31 \mathrm{~b}$ & $13.012,75$ \\
\hline 6 & 18 & $21.008,71$ & 7 & 13 & $15.344,56$ & 8 & 9 & $6.316 .467,00$ \\
\hline 6 & 19 & $24.044,62$ & 7 & 14 & $37.084,04$ & 8 & 10 & $10.628,51$ \\
\hline 6 & 20 & $10.601,73$ & 7 & 15 & $12.339,33$ & 8 & 11 & $13.471,28$ \\
\hline 6 & 21 & $12.122,37$ & 7 & 16 & $29.465,39$ & 8 & 12 & $15.893,78$ \\
\hline 6 & 22 & $17.158,99$ & 7 & 17 & $22.096,49$ & 8 & 13 & $19.885,14$ \\
\hline 6 & 23 & $14.657,98$ & 7 & 18 & $17.627,03$ & 8 & 14 & $41.624,62$ \\
\hline 6 & 24 & $9.436 .941,00$ & 7 & 19 & $20.662,93$ & 8 & 15 & $16.879,95$ \\
\hline 6 & 25 & $11.522,17$ & 7 & 20 & $11.063,21$ & 8 & 16 & $34.005,98$ \\
\hline 6 & 26 & $15.920,25$ & 7 & 21 & $5.523 .501,00$ & 8 & 17 & $26.637,12$ \\
\hline 6 & 27 & $12.591,16$ & 7 & 22 & 7.368.291,00 & 8 & 18 & $22.167,61$ \\
\hline 6 & 28 & $7.161,65$ & 7 & 23 & $14.165,44$ & 8 & 19 & $25.203,52$ \\
\hline 6 & 29 & $4.314 .029,00$ & 7 & 24 & $8.770 .414,00$ & 8 & 20 & $15.603,79$ \\
\hline 6 & 30 & $15.817,50$ & 7 & 25 & $11.178,76$ & 8 & 21 & $9.499 .312,00$ \\
\hline 6 & $31 a$ & $22.757,69$ & 7 & 26 & $15.576,84$ & 8 & 22 & $2.795,33$ \\
\hline 6 & 32 & 2.347.021,00 & 7 & 27 & $13.339,51$ & 8 & 23 & $18.706,03$ \\
\hline 6 & 33 & $3.304 .421,00$ & 7 & 28 & $6.669,11$ & 8 & 24 & $13.311,01$ \\
\hline 6 & 34 & $30.521,36$ & 7 & 29 & $6.537 .762,00$ & 8 & 25 & $15.719,35$ \\
\hline 6 & 35 & $32.838,92$ & 7 & 30 & $20.775,21$ & 8 & 26 & $20.117,45$ \\
\hline
\end{tabular}

Continua... 


\begin{tabular}{|c|c|c|c|c|c|c|c|c|}
\hline \multicolumn{2}{|c|}{ Nodo } & \multirow{2}{*}{$\begin{array}{c}\text { Enlace } \\
17.880,10\end{array}$} & \multicolumn{2}{|c|}{ Nodo } & \multirow{2}{*}{$\begin{array}{c}\text { Enlace } \\
18.097,79\end{array}$} & \multicolumn{2}{|c|}{ Nodo } & \multirow{2}{*}{$\begin{array}{c}\text { Enlace } \\
7.882 .871,00\end{array}$} \\
\hline 8 & 27 & & 9 & 24 & & 10 & 22 & \\
\hline 8 & 28 & $11.209,70$ & 9 & 25 & $20.505,87$ & 10 & 23 & $25.611,39$ \\
\hline 8 & 29 & $11.078,34$ & 9 & 26 & $24.904,10$ & 10 & 24 & $20.216,40$ \\
\hline 8 & 30 & $25.315,78$ & 9 & 27 & $22.661,03$ & 10 & 25 & $22.624,34$ \\
\hline 8 & $31 a$ & $23.916,59$ & 9 & 28 & $15.996,48$ & 10 & 26 & $27.022,58$ \\
\hline 8 & 32 & $12.943,01$ & 9 & 29 & $15.452,77$ & 10 & 27 & $24.785,43$ \\
\hline 8 & 33 & $14.567,74$ & 9 & 30 & $29.786,68$ & 10 & 28 & $18.115,02$ \\
\hline 8 & 34 & $40.019,77$ & 9 & $31 a$ & $25.694,28$ & 10 & 29 & $18.153,47$ \\
\hline 8 & 35 & $42.337,35$ & 9 & 32 & $17.425,62$ & 10 & 30 & $32.220,98$ \\
\hline 8 & 36 & $24.873,26$ & 9 & 33 & $19.038,66$ & 10 & $31 a$ & $22.650,62$ \\
\hline 8 & 37 & $33.651,31$ & 9 & 34 & $44.490,48$ & 10 & 32 & $19.848,16$ \\
\hline 8 & 38 & $57.375,54$ & 9 & 35 & $46.808,06$ & 10 & 33 & $21.472,97$ \\
\hline 8 & 39 & $13.375,08$ & 9 & 36 & $26.746,22$ & 10 & 34 & $46.924,79$ \\
\hline 8 & 40 & $11.690,17$ & 9 & 37 & $35.428,95$ & 10 & 35 & $49.242,36$ \\
\hline 8 & 41 & $14.839,98$ & 9 & 38 & $61.846,25$ & 10 & 36 & $26.546,82$ \\
\hline 8 & 42 & $45.450,96$ & 9 & 39 & $14.793,76$ & 10 & 37 & $32.225,97$ \\
\hline 8 & 43 & $14.943,61$ & 9 & 40 & $16.958,40$ & 10 & 38 & $63.652,48$ \\
\hline 8 & 44 & $13.308,39$ & 9 & 41 & $19.310,93$ & 10 & 39 & $10.190,41$ \\
\hline 8 & 45 & $9.686 .438,00$ & 9 & 42 & $49.921,67$ & 10 & 40 & $18.595,57$ \\
\hline 8 & 46 & $9.294,13$ & 9 & 43 & $20.488,60$ & 10 & 41 & $21.745,61$ \\
\hline 8 & 47 & $10.884,11$ & 9 & 44 & $18.853,37$ & 10 & 42 & $52.355,98$ \\
\hline 8 & $31 \mathrm{c}$ & $5.467 .937,00$ & 9 & 45 & $11.207,05$ & 10 & 43 & $17.076,41$ \\
\hline 8 & $31 \mathrm{~b}$ & $14.785,83$ & 9 & 46 & $10.712,82$ & 10 & 44 & $15.441,18$ \\
\hline 9 & 10 & $5.015 .827,00$ & 9 & 47 & $12.302,80$ & 10 & 45 & $15.851,33$ \\
\hline 9 & 11 & $15.248,97$ & 9 & $31 \mathrm{c}$ & $10.649,57$ & 10 & 46 & $6.109 .499,00$ \\
\hline 9 & 12 & $17.766,75$ & 9 & $31 b$ & $16.204,52$ & 10 & 47 & $7.699 .445,00$ \\
\hline 9 & 13 & $24.259,58$ & 10 & 11 & $11.774,32$ & 10 & $31 c$ & $6.046 .239,00$ \\
\hline 9 & 14 & $43.402,30$ & 10 & 12 & $20.969,77$ & 10 & $31 b$ & $11.601,17$ \\
\hline 9 & 15 & $21.350,66$ & 10 & 13 & $26.960,26$ & 11 & 12 & $9.518 .192,00$ \\
\hline 9 & 16 & $38.476,69$ & 10 & 14 & $40.100,07$ & 11 & 13 & $16.898,81$ \\
\hline 9 & 17 & $31.107,82$ & 10 & 15 & $23.784,96$ & 11 & 14 & $29.071,04$ \\
\hline 9 & 18 & $23.945,30$ & 10 & 16 & $40.910,99$ & 11 & 15 & $13.990,17$ \\
\hline 9 & 19 & $27.076,48$ & 10 & 17 & $33.542,09$ & 11 & 16 & $31.116,22$ \\
\hline 9 & 20 & $17.831,26$ & 10 & 18 & $21.218,25$ & 11 & 17 & $23.747,33$ \\
\hline 9 & 21 & $7.558 .995,00$ & 10 & 19 & $26.756,70$ & 11 & 18 & $9.773,77$ \\
\hline 9 & 22 & $8.340 .199,00$ & 10 & 20 & $21.034,30$ & 11 & 19 & $15.163,73$ \\
\hline 9 & 23 & $23.492,80$ & 10 & 21 & $12.563,11$ & 11 & 20 & $9.582 .702,00$ \\
\hline
\end{tabular}

Continua... 


\begin{tabular}{|c|c|c|c|c|c|c|c|c|}
\hline \multicolumn{2}{|c|}{ Nodo } & \multirow{2}{*}{$\begin{array}{c}\text { Enlace } \\
7.698 .213,00\end{array}$} & \multicolumn{2}{|c|}{ Nodo } & \multirow{2}{*}{$\begin{array}{c}\text { Enlace } \\
10.216,03\end{array}$} & \multicolumn{2}{|c|}{ Nodo } & \multirow{2}{*}{$\begin{array}{c}\text { Enlace } \\
22.023,58\end{array}$} \\
\hline 11 & 21 & & 12 & 21 & & 13 & 22 & \\
\hline 11 & 22 & $12.213,30$ & 12 & 22 & $18.032,22$ & 13 & 23 & $20.321,31$ \\
\hline 11 & 23 & $16.132,05$ & 12 & 23 & $18.554,60$ & 13 & 24 & $15.100,28$ \\
\hline 11 & 24 & $10.737,03$ & 12 & 24 & $13.159,58$ & 13 & 25 & $17.185,50$ \\
\hline 11 & 25 & $13.145,37$ & 12 & 25 & $15.567,92$ & 13 & 26 & $21.583,60$ \\
\hline 11 & 26 & $17.543,46$ & 12 & 26 & $19.966,02$ & 13 & 27 & $18.532,60$ \\
\hline 11 & 27 & $15.300,26$ & 12 & 27 & $17.722,81$ & 13 & 28 & $12.824,98$ \\
\hline 11 & 28 & $8.635 .721,00$ & 12 & 28 & $11.058,27$ & 13 & 29 & $9.584 .219,00$ \\
\hline 11 & 29 & $8.092 .012,00$ & 12 & 29 & $10.514,56$ & 13 & 30 & $23.894,01$ \\
\hline 11 & 30 & $22.425,84$ & 12 & 30 & $24.848,71$ & 13 & $31 a$ & $21.846,69$ \\
\hline 11 & $31 a$ & $11.362,97$ & 12 & $31 a$ & $19.528,10$ & 13 & 32 & $11.617,72$ \\
\hline 11 & 32 & $10.064,94$ & 12 & 32 & $12.487,49$ & 13 & 33 & $13.145,81$ \\
\hline 11 & 33 & $11.677,96$ & 12 & 33 & $14.100,51$ & 13 & 34 & $38.597,83$ \\
\hline 11 & 34 & $37.129,98$ & 12 & 34 & $39.552,54$ & 13 & 35 & $40.915,41$ \\
\hline 11 & 35 & $39.447,56$ & 12 & 35 & $41.870,11$ & 13 & 36 & $7.985 .838,00$ \\
\hline 11 & 36 & $14.891,47$ & 12 & 36 & $19.083,19$ & 13 & 37 & $31.587,75$ \\
\hline 11 & 37 & $21.097,70$ & 12 & 37 & $29.262,82$ & 13 & 38 & $55.953,60$ \\
\hline 11 & 38 & $52.524,21$ & 12 & 38 & $56.908,30$ & 13 & 39 & $18.193,14$ \\
\hline 11 & 39 & $1.617 .019,00$ & 12 & 39 & $10.812,49$ & 13 & 40 & $15.431,11$ \\
\hline 11 & 40 & $9.597 .631,00$ & 12 & 40 & $12.020,19$ & 13 & 41 & $13.418,05$ \\
\hline 11 & 41 & $11.950,23$ & 12 & 41 & $14.372,73$ & 13 & 42 & $44.029,02$ \\
\hline 11 & 42 & $42.561,17$ & 12 & 42 & $44.983,73$ & 13 & 43 & $23.138,54$ \\
\hline 11 & 43 & $16.724,58$ & 12 & 43 & $19.147,17$ & 13 & 44 & $21.503,31$ \\
\hline 11 & 44 & $15.089,35$ & 12 & 44 & $17.511,94$ & 13 & 45 & $13.114,02$ \\
\hline 11 & 45 & $4.399 .729,00$ & 12 & 45 & $6.822 .271,00$ & 13 & 46 & $22.428,65$ \\
\hline 11 & 46 & $5.852 .477,00$ & 12 & 46 & $15.048,00$ & 13 & 47 & $22.716,65$ \\
\hline 11 & 47 & $6.140 .466,00$ & 12 & 47 & $15.336,00$ & 13 & $31 \mathrm{c}$ & $21.136,90$ \\
\hline 11 & $31 \mathrm{c}$ & $10.347,37$ & 12 & $31 \mathrm{c}$ & $17.145,53$ & 13 & $31 b$ & $20.980,93$ \\
\hline 11 & $31 \mathrm{~b}$ & $4.090 .312,00$ & 12 & $31 \mathrm{~b}$ & $13.600,28$ & 14 & 15 & $42.043,59$ \\
\hline 12 & 13 & $19.321,36$ & 13 & 14 & $39.462,05$ & 14 & 16 & $50.619,71$ \\
\hline 12 & 14 & $37.137,10$ & 13 & 15 & $15.458,02$ & 14 & 17 & $41.672,27$ \\
\hline 12 & 15 & $16.412,72$ & 13 & 16 & $32.455,13$ & 14 & 18 & $22.591,62$ \\
\hline 12 & 16 & $33.538,75$ & 13 & 17 & $23.507,65$ & 14 & 19 & $25.854,79$ \\
\hline 12 & 17 & $26.169,88$ & 13 & 18 & $18.508,42$ & 14 & 20 & $37.480,94$ \\
\hline 12 & 18 & $16.982,66$ & 13 & 19 & $17.767,69$ & 14 & 21 & $35.752,53$ \\
\hline 12 & 19 & $19.413,44$ & 13 & 20 & $14.606,15$ & 14 & 22 & $40.539,10$ \\
\hline 12 & 20 & $10.188,12$ & 13 & 21 & $16.708,86$ & 14 & 23 & $44.185,58$ \\
\hline
\end{tabular}

Continua... 


\begin{tabular}{|c|c|c|c|c|c|c|c|c|}
\hline \multicolumn{2}{|c|}{ Nodo } & \multirow{2}{*}{$\begin{array}{c}\text { Enlace } \\
38.790,93\end{array}$} & \multicolumn{2}{|c|}{ Nodo } & \multirow{2}{*}{$\begin{array}{c}\text { Enlace } \\
8.851 .116,00\end{array}$} & \multicolumn{2}{|c|}{ Nodo } & \multirow{2}{*}{$\begin{array}{c}\text { Enlace } \\
22.259,86\end{array}$} \\
\hline 14 & 24 & & 15 & 28 & & 16 & 32 & \\
\hline 14 & 25 & $41.198,88$ & 15 & 29 & $5.906 .849,00$ & 16 & 33 & $22.462,76$ \\
\hline 14 & 26 & $45.597,14$ & 15 & 30 & $12.612,85$ & 16 & 34 & $29.086,11$ \\
\hline 14 & 27 & $43.354,09$ & 15 & $31 a$ & $24.435,44$ & 16 & 35 & $31.403,68$ \\
\hline 14 & 28 & $36.689,59$ & 15 & 32 & $5.133 .993,00$ & 16 & 36 & $24.502,42$ \\
\hline 14 & 29 & $36.145,92$ & 15 & 33 & $5.336 .833,00$ & 16 & 37 & $42.744,57$ \\
\hline 14 & $31 a$ & $17.615,39$ & 15 & 34 & $25.701,56$ & 16 & 38 & $46.441,95$ \\
\hline 14 & 32 & $38.118,60$ & 15 & 35 & $28.019,14$ & 16 & 39 & $32.409,58$ \\
\hline 14 & 33 & $39.731,62$ & 15 & 36 & $22.776,50$ & 16 & 40 & $28.882,54$ \\
\hline 14 & 34 & $30.668,98$ & 15 & 37 & $34.170,16$ & 16 & 41 & $20.500,42$ \\
\hline 14 & 35 & $27.865,71$ & 15 & 38 & $43.057,45$ & 16 & 42 & $34.517,37$ \\
\hline 14 & 36 & $31.509,39$ & 15 & 39 & $15.284,41$ & 16 & 43 & $37.088,96$ \\
\hline 14 & 37 & $18.724,27$ & 15 & 40 & $11.757,04$ & 16 & 44 & $35.453,77$ \\
\hline 14 & 38 & $24.079,13$ & 15 & 41 & $3.374 .393,00$ & 16 & 45 & $27.330,63$ \\
\hline 14 & 39 & $30.588,29$ & 15 & 42 & $31.132,83$ & 16 & 46 & $36.644,88$ \\
\hline 14 & 40 & $37.651,69$ & 15 & 43 & $19.963,41$ & 16 & 47 & $36.932,84$ \\
\hline 14 & 41 & $40.003,79$ & 15 & 44 & $18.328,18$ & 16 & $31 \mathrm{c}$ & $35.087,07$ \\
\hline 14 & 42 & $24.629,01$ & 15 & 45 & $10.205,29$ & 16 & $31 b$ & $34.055,98$ \\
\hline 14 & 43 & $44.778,11$ & 15 & 46 & $19.519,92$ & 17 & 18 & $20.718,63$ \\
\hline 14 & 44 & $43.142,92$ & 15 & 47 & $19.807,92$ & 17 & 19 & $19.977,91$ \\
\hline 14 & 45 & $32.454,09$ & 15 & $31 c$ & $17.961,77$ & 17 & 20 & $21.951,69$ \\
\hline 14 & 46 & $34.178,46$ & 15 & $31 b$ & $18.072,20$ & 17 & 21 & $23.556,99$ \\
\hline 14 & 47 & $34.466,45$ & 16 & 17 & $9.278 .021,00$ & 17 & 22 & $28.605,58$ \\
\hline 14 & $31 c$ & $38.673,13$ & 16 & 18 & $29.666,13$ & 17 & 23 & $26.104,64$ \\
\hline 14 & $31 b$ & $28.499,15$ & 16 & 19 & $28.925,40$ & 17 & 24 & $20.883,56$ \\
\hline 15 & 16 & $17.126,03$ & 16 & 20 & $29.320,12$ & 17 & 25 & $22.968,53$ \\
\hline 15 & 17 & $9.757 .137,00$ & 16 & 21 & $30.925,44$ & 17 & 26 & $27.366,77$ \\
\hline 15 & 18 & $22.686,46$ & 16 & 22 & $35.973,94$ & 17 & 27 & $24.315,77$ \\
\hline 15 & 19 & $25.722,37$ & 16 & 23 & $33.473,08$ & 17 & 28 & $18.608,27$ \\
\hline 15 & 20 & $12.194,55$ & 16 & 24 & $28.252,05$ & 17 & 29 & $15.664,09$ \\
\hline 15 & 21 & $13.800,12$ & 16 & 25 & $30.337,02$ & 17 & 30 & $22.370,01$ \\
\hline 15 & 22 & $18.848,45$ & 16 & 26 & $34.735,24$ & 17 & $31 a$ & $24.056,90$ \\
\hline 15 & 23 & $16.347,45$ & 16 & 27 & $31.684,26$ & 17 & 32 & $14.891,22$ \\
\hline 15 & 24 & $11.126,41$ & 16 & 28 & $25.976,76$ & 17 & 33 & $15.094,06$ \\
\hline 15 & 25 & $13.211,63$ & 16 & 29 & $23.032,62$ & 17 & 34 & $26.680,33$ \\
\hline 15 & 26 & $17.609,72$ & 16 & 30 & $29.738,90$ & 17 & 35 & $27.724,33$ \\
\hline 15 & 27 & $14.558,74$ & 16 & $31 a$ & $33.004,38$ & 17 & 36 & $15.554,93$ \\
\hline
\end{tabular}

Continua... 


\begin{tabular}{|c|c|c|c|c|c|c|c|c|}
\hline \multicolumn{2}{|c|}{ Nodo } & \multirow{2}{*}{$\begin{array}{c}\text { Enlace } \\
33.797,95\end{array}$} & \multicolumn{2}{|c|}{ Nodo } & \multirow{2}{*}{$\begin{array}{c}\text { Enlace } \\
25.420,98\end{array}$} & \multicolumn{2}{|c|}{ Nodo } & \multirow{2}{*}{$\begin{array}{c}\text { Enlace } \\
10.280,53\end{array}$} \\
\hline 17 & 37 & & 18 & 43 & & 20 & 21 & \\
\hline 17 & 38 & $42.885,67$ & 18 & 44 & $23.785,75$ & 20 & 22 & $17.742,22$ \\
\hline 17 & 39 & $25.041,13$ & 18 & 45 & $13.096,07$ & 20 & 23 & $16.685,09$ \\
\hline 17 & 40 & $21.514,05$ & 18 & 46 & $15.296,42$ & 20 & 24 & $11.464,06$ \\
\hline 17 & 41 & $13.131,52$ & 18 & 47 & $15.584,41$ & 20 & 25 & $13.549,28$ \\
\hline 17 & 42 & $30.961,03$ & 18 & $31 \mathrm{c}$ & $19.791,35$ & 20 & 26 & $17.947,36$ \\
\hline 17 & 43 & $29.720,54$ & 18 & $31 \mathrm{~b}$ & $9.617,01$ & 20 & 27 & $14.896,38$ \\
\hline 17 & 44 & $28.085,31$ & 19 & 20 & $20.501,69$ & 20 & 28 & $9.188 .758,00$ \\
\hline 17 & 45 & $19.962,18$ & 19 & 21 & $19.525,75$ & 20 & 29 & $6.296 .475,00$ \\
\hline 17 & 46 & $29.276,64$ & 19 & 22 & $27.195,78$ & 20 & 30 & $20.630,60$ \\
\hline 17 & 47 & $29.564,64$ & 19 & 23 & $27.863,99$ & 20 & $31 a$ & $19.871,95$ \\
\hline 17 & $31 \mathrm{c}$ & $27.718,90$ & 19 & 24 & $22.469,01$ & 20 & 32 & $8.354,33$ \\
\hline 17 & $31 \mathrm{~b}$ & $25.108,56$ & 19 & 25 & $24.876,95$ & 20 & 33 & $9.882 .412,00$ \\
\hline 18 & 19 & $5.538 .426,00$ & 19 & 26 & $29.275,18$ & 20 & 34 & $35.334,43$ \\
\hline 18 & 20 & $18.070,91$ & 19 & 27 & $27.032,24$ & 20 & 35 & $37.652,00$ \\
\hline 18 & 21 & $16.394,55$ & 19 & 28 & $20.367,62$ & 20 & 36 & $20.171,41$ \\
\hline 18 & 22 & $21.657,26$ & 19 & 29 & $19.823,95$ & 20 & 37 & $29.606,68$ \\
\hline 18 & 23 & $24.828,36$ & 19 & 30 & $34.158,15$ & 20 & 38 & $52.690,19$ \\
\hline 18 & 24 & $19.433,36$ & 19 & $31 a$ & $8.456,10$ & 20 & 39 & $10.877,00$ \\
\hline 18 & 25 & $21.841,31$ & 19 & 32 & $21.796,65$ & 20 & 40 & $11.149,75$ \\
\hline 18 & 26 & $26.239,55$ & 19 & 33 & $23.409,74$ & 20 & 41 & $10.154,64$ \\
\hline 18 & 27 & $23.996,44$ & 19 & 34 & $46.288,29$ & 20 & 42 & $40.765,62$ \\
\hline 18 & 28 & $17.331,98$ & 19 & 35 & $43.622,86$ & 20 & 43 & $18.857,17$ \\
\hline 18 & 29 & $16.788,31$ & 19 & 36 & $9.814 .927,00$ & 20 & 44 & $17.221,94$ \\
\hline 18 & 30 & $31.122,11$ & 19 & 37 & $17.980,42$ & 20 & 45 & $6.886 .774,00$ \\
\hline 18 & $31 a$ & $4.976 .169,00$ & 19 & 38 & $49.406,93$ & 20 & 46 & $15.112,51$ \\
\hline 18 & 32 & $18.761,03$ & 19 & 39 & $16.779,85$ & 20 & 47 & $15.400,50$ \\
\hline 18 & 33 & $20.374,10$ & 19 & 40 & $21.329,76$ & 20 & $31 \mathrm{c}$ & $16.855,54$ \\
\hline 18 & 34 & $43.252,40$ & 19 & 41 & $23.682,46$ & 20 & $31 \mathrm{~b}$ & $13.664,78$ \\
\hline 18 & 35 & $40.359,66$ & 19 & 42 & $42.583,34$ & 21 & 22 & $12.282,06$ \\
\hline 18 & 36 & $10.555,62$ & 19 & 43 & $28.456,77$ & 21 & 23 & $15.942,08$ \\
\hline 18 & 37 & $14.717,08$ & 19 & 44 & $26.821,54$ & 21 & 24 & $10.547,06$ \\
\hline 18 & 38 & $46.143,59$ & 19 & 45 & $16.132,02$ & 21 & 25 & $12.955,41$ \\
\hline 18 & 39 & $11.389,81$ & 19 & 46 & $20.834,94$ & 21 & 26 & $17.353,49$ \\
\hline 18 & 40 & $18.293,92$ & 19 & 47 & $21.122,94$ & 21 & 27 & $15.110,30$ \\
\hline 18 & 41 & $20.646,56$ & 19 & $31 \mathrm{c}$ & $25.329,88$ & 21 & 28 & $8.445 .754,00$ \\
\hline 18 & 42 & $39.320,14$ & 19 & $31 b$ & $15.155,53$ & 21 & 29 & $7.902 .045,00$ \\
\hline
\end{tabular}

Continua... 


\begin{tabular}{|c|c|c|c|c|c|c|c|c|}
\hline \multicolumn{2}{|c|}{ Nodo } & \multirow{2}{*}{$\begin{array}{c}\text { Enlace } \\
22.235,97\end{array}$} & \multicolumn{2}{|c|}{ Nodo } & \multirow{2}{*}{$\begin{array}{c}\text { Enlace } \\
13.658,70\end{array}$} & \multicolumn{2}{|c|}{ Nodo } & \multirow{2}{*}{$\begin{array}{c}\text { Enlace } \\
12.466,00\end{array}$} \\
\hline 21 & 30 & & 22 & 40 & & 24 & 26 & \\
\hline 21 & $31 a$ & $18.143,57$ & 22 & 41 & $16.808,56$ & 24 & 27 & $10.944,73$ \\
\hline 21 & 32 & $9.874 .973,00$ & 22 & 42 & $47.419,45$ & 24 & 28 & $2.907 .096,00$ \\
\hline 21 & 33 & $11.487,99$ & 22 & 43 & $12.197,97$ & 24 & 29 & $5.516 .024,00$ \\
\hline 21 & 34 & $36.940,01$ & 22 & 44 & $10.562,75$ & 24 & 30 & $19.562,45$ \\
\hline 21 & 35 & $39.257,59$ & 22 & 45 & $11.824,80$ & 24 & $31 a$ & $21.182,36$ \\
\hline 21 & 36 & $19.195,50$ & 22 & 46 & $6.548 .484,00$ & 24 & 32 & $7.189 .524,00$ \\
\hline 21 & 37 & $27.878,29$ & 22 & 47 & $8.138,43$ & 24 & 33 & $8.814 .244,00$ \\
\hline 21 & 38 & $54.295,78$ & 22 & $31 \mathrm{c}$ & $2.722 .314,00$ & 24 & 34 & $34.266,27$ \\
\hline 21 & 39 & $8.992 .502,00$ & 22 & $31 \mathrm{~b}$ & $12.040,16$ & 24 & 35 & $36.583,85$ \\
\hline 21 & 40 & $9.407 .664,00$ & 23 & 24 & $10.560,81$ & 24 & 36 & $22.139,02$ \\
\hline 21 & 41 & $11.760,22$ & 23 & 25 & $10.715,75$ & 24 & 37 & $30.917,09$ \\
\hline 21 & 42 & $42.371,20$ & 23 & 26 & $15.130,40$ & 24 & 38 & $51.622,04$ \\
\hline 21 & 43 & $16.534,60$ & 23 & 27 & $15.331,90$ & 24 & 39 & $12.031,32$ \\
\hline 21 & 44 & $14.899,38$ & 23 & 28 & $7.755 .791,00$ & 24 & 40 & $4.702 .531,00$ \\
\hline 21 & 45 & $3.656 .338,00$ & 23 & 29 & $10.737,00$ & 24 & 41 & $9.086 .514,00$ \\
\hline 21 & 46 & $13.228,01$ & 23 & 30 & $24.783,43$ & 24 & 42 & $39.697,46$ \\
\hline 21 & 47 & $13.516,01$ & 23 & $31 a$ & $26.577,32$ & 24 & 43 & $16.394,46$ \\
\hline 21 & $31 \mathrm{c}$ & $14.532,99$ & 23 & 32 & $12.410,50$ & 24 & 44 & $14.759,24$ \\
\hline 21 & $31 b$ & $11.780,29$ & 23 & 33 & $14.035,24$ & 24 & 45 & $6.952,20$ \\
\hline 22 & 23 & $20.674,55$ & 23 & 34 & $39.487,26$ & 24 & 46 & $16.266,83$ \\
\hline 22 & 24 & $15.279,53$ & 23 & 35 & $41.804,84$ & 24 & 47 & $16.554,83$ \\
\hline 22 & 25 & $17.687,88$ & 23 & 36 & $27.533,99$ & 24 & $31 c$ & $14.392,85$ \\
\hline 22 & 26 & $22.085,98$ & 23 & 37 & $36.311,90$ & 24 & $31 b$ & $14.819,11$ \\
\hline 22 & 27 & $19.848,62$ & 23 & 38 & $56.843,03$ & 25 & 26 & $9.466 .523,00$ \\
\hline 22 & 28 & $13.178,22$ & 23 & 39 & $17.426,29$ & 25 & 27 & $10.556,09$ \\
\hline 22 & 29 & $13.216,71$ & 23 & 40 & $10.029,88$ & 25 & 28 & $5.160 .789,00$ \\
\hline 22 & 30 & $27.284,41$ & 23 & 41 & $14.307,55$ & 25 & 29 & $7.601 .203,00$ \\
\hline 22 & $31 a$ & $23.089,62$ & 23 & 42 & $44.918,45$ & 25 & 30 & $21.647,64$ \\
\hline 22 & 32 & $14.911,53$ & 23 & 43 & $21.789,49$ & 25 & $31 a$ & $23.590,66$ \\
\hline 22 & 33 & $16.536,26$ & 23 & 44 & $20.154,26$ & 25 & 32 & $9.274 .708,00$ \\
\hline 22 & 34 & $41.988,25$ & 23 & 45 & $12.347,17$ & 25 & 33 & $10.899,44$ \\
\hline 22 & 35 & $44.305,83$ & 23 & 46 & $21.661,80$ & 25 & 34 & $36.351,46$ \\
\hline 22 & 36 & $26.985,81$ & 23 & 47 & $21.949,79$ & 25 & 35 & $38.669,04$ \\
\hline 22 & 37 & $32.664,97$ & 23 & $31 \mathrm{c}$ & $19.787,85$ & 25 & 36 & $24.452,86$ \\
\hline 22 & 38 & $59.344,02$ & 23 & $31 b$ & $20.214,08$ & 25 & 37 & $33.325,38$ \\
\hline 22 & 39 & $10.629,41$ & 24 & 25 & $8.067 .909,00$ & 25 & 38 & $53.707,23$ \\
\hline
\end{tabular}

Continua... 


\begin{tabular}{|c|c|c|c|c|c|c|c|c|}
\hline \multicolumn{2}{|c|}{ Nodo } & \multirow{2}{*}{$\begin{array}{c}\text { Enlace } \\
14.439,63\end{array}$} & \multicolumn{2}{|c|}{ Nodo } & \multirow{2}{*}{$\begin{array}{c}\text { Enlace } \\
25.745,60\end{array}$} & \multicolumn{2}{|c|}{ Nodo } & \multirow{2}{*}{$\begin{array}{c}\text { Enlace } \\
14.453,46\end{array}$} \\
\hline 25 & 39 & & 27 & $31 a$ & & 28 & 47 & \\
\hline 25 & 40 & $7.988 .395,00$ & 27 & 32 & $10.621,85$ & 28 & $31 \mathrm{c}$ & $12.291,50$ \\
\hline 25 & 41 & $11.171,74$ & 27 & 33 & $12.246,59$ & 28 & $31 \mathrm{~b}$ & $12.717,74$ \\
\hline 25 & 42 & $41.782,65$ & 27 & 34 & $37.698,61$ & 29 & 30 & $14.342,81$ \\
\hline 25 & 43 & $18.802,82$ & 27 & 35 & $40.016,19$ & 29 & $31 a$ & $18.537,29$ \\
\hline 25 & 44 & $17.167,59$ & 27 & 36 & $25.800,01$ & 29 & 32 & $2.066 .593,00$ \\
\hline 25 & 45 & $9.360 .508,00$ & 27 & 37 & $35.480,26$ & 29 & 33 & $3.594 .675,00$ \\
\hline 25 & 46 & $18.675,14$ & 27 & 38 & $55.054,38$ & 29 & 34 & $29.046,71$ \\
\hline 25 & 47 & $18.963,14$ & 27 & 39 & $16.594,57$ & 29 & 35 & $31.364,29$ \\
\hline 25 & $31 \mathrm{c}$ & $16.801,19$ & 27 & 40 & $11.315,15$ & 29 & 36 & $16.902,79$ \\
\hline 25 & $31 \mathrm{~b}$ & $17.227,42$ & 27 & 41 & $12.518,84$ & 29 & 37 & $28.272,01$ \\
\hline 26 & 27 & $5.530 .658,00$ & 27 & 42 & $43.129,80$ & 29 & 38 & $46.402,55$ \\
\hline 26 & 28 & $9.558 .946,00$ & 27 & 43 & $20.963,63$ & 29 & 39 & $9.386 .232,00$ \\
\hline 26 & 29 & $11.999,36$ & 27 & 44 & $19.328,40$ & 29 & 40 & $6.146 .604,00$ \\
\hline 26 & 30 & $26.045,59$ & 27 & 45 & $11.515,45$ & 29 & 41 & $3.866 .955,00$ \\
\hline 26 & $31 a$ & $27.988,82$ & 27 & 46 & $20.830,08$ & 29 & 42 & $34.477,98$ \\
\hline 26 & 32 & $13.672,87$ & 27 & 47 & $21.118,07$ & 29 & 43 & $14.331,52$ \\
\hline 26 & 33 & $15.297,60$ & 27 & $31 \mathrm{c}$ & $18.961,99$ & 29 & 44 & $12.696,30$ \\
\hline 26 & 34 & $40.749,63$ & 27 & $31 b$ & $19.382,36$ & 29 & 45 & $4.307 .123,00$ \\
\hline 26 & 35 & $43.067,21$ & 28 & 29 & $3.240 .719,00$ & 29 & 46 & $13.621,74$ \\
\hline 26 & 36 & $28.851,03$ & 28 & 30 & $17.287,09$ & 29 & 47 & $13.909,74$ \\
\hline 26 & 37 & $37.723,21$ & 28 & $31 a$ & $19.081,00$ & 29 & $31 \mathrm{c}$ & $12.329,96$ \\
\hline 26 & 38 & $58.105,40$ & 28 & 32 & $4.914 .186,00$ & 29 & $31 \mathrm{~b}$ & $12.174,01$ \\
\hline 26 & 39 & $18.837,79$ & 28 & 33 & $6.538 .923,00$ & 30 & $31 a$ & $32.871,20$ \\
\hline 26 & 40 & $12.386,56$ & 28 & 34 & $31.991,02$ & 30 & 32 & $13.570,05$ \\
\hline 26 & 41 & $15.569,82$ & 28 & 35 & $34.308,53$ & 30 & 33 & $13.772,88$ \\
\hline 26 & 42 & $46.180,82$ & 28 & 36 & $20.037,67$ & 30 & 34 & $25.919,84$ \\
\hline 26 & 43 & $23.200,99$ & 28 & 37 & $28.815,73$ & 30 & 35 & $28.237,41$ \\
\hline 26 & 44 & $21.565,76$ & 28 & 38 & $49.346,72$ & 30 & 36 & $31.212,57$ \\
\hline 26 & 45 & $13.758,67$ & 28 & 39 & $9.929 .949,00$ & 30 & 37 & $42.605,13$ \\
\hline 26 & 46 & $23.073,30$ & 28 & 40 & $3.026 .438,00$ & 30 & 38 & $43.275,70$ \\
\hline 26 & 47 & $23.361,29$ & 28 & 41 & $6.811 .223,00$ & 30 & 39 & $23.720,11$ \\
\hline 26 & $31 \mathrm{c}$ & $21.199,35$ & 28 & 42 & $37.422,14$ & 30 & 40 & $20.192,93$ \\
\hline 26 & $31 \mathrm{~b}$ & $21.625,58$ & 28 & 43 & $14.293,05$ & 30 & 42 & $31.351,11$ \\
\hline 27 & 28 & $8.288 .693,00$ & 28 & 44 & $12.657,83$ & 30 & 43 & $28.399,37$ \\
\hline 27 & 29 & $8.948 .349,00$ & 28 & 45 & $4.850 .835,00$ & 30 & 44 & $26.764,14$ \\
\hline 27 & 30 & $22.994,79$ & 28 & 46 & $14.165,46$ & 30 & 45 & $18.641,16$ \\
\hline
\end{tabular}

Continua... 


\begin{tabular}{|c|c|c|c|c|c|c|c|c|}
\hline \multicolumn{2}{|c|}{ Nodo } & \multirow{2}{*}{$\begin{array}{c}\text { Enlace } \\
27.955,62\end{array}$} & \multicolumn{2}{|c|}{ Nodo } & \multirow{2}{*}{$\begin{array}{c}\text { Enlace } \\
28.476,72\end{array}$} & \multicolumn{2}{|c|}{ Nodo } & \multirow{2}{*}{$\begin{array}{c}\text { Enlace } \\
3.236,69\end{array}$} \\
\hline 30 & 46 & & 33 & 34 & & 35 & 42 & \\
\hline 30 & 47 & $28.243,62$ & 33 & 35 & $30.794,30$ & 35 & 43 & $45.419,79$ \\
\hline 30 & $31 c$ & $26.397,72$ & 33 & 36 & $20.464,32$ & 35 & 44 & $43.784,60$ \\
\hline 30 & $31 b$ & $26.507,90$ & 33 & 37 & $31.857,98$ & 35 & 45 & $35.662,02$ \\
\hline $31 a$ & 32 & $20.509,74$ & 33 & 38 & $45.832,56$ & 35 & 46 & $44.976,16$ \\
\hline $31 a$ & 33 & $22.122,83$ & 33 & 39 & $12.972,22$ & 35 & 47 & $45.264,13$ \\
\hline $31 a$ & 34 & $38.334,17$ & 33 & 40 & $9.444 .856,00$ & 35 & $31 \mathrm{c}$ & $43.418,36$ \\
\hline $31 a$ & 35 & $35.441,44$ & 33 & 41 & $3.176 .377,00$ & 35 & $31 b$ & $43.528,55$ \\
\hline $31 a$ & 36 & $13.893,89$ & 33 & 42 & $33.907,99$ & 36 & 37 & $23.634,90$ \\
\hline $31 a$ & 37 & $9.740 .842,00$ & 33 & 43 & $17.651,21$ & 36 & 38 & $55.061,41$ \\
\hline $31 a$ & 38 & $41.167,35$ & 33 & 44 & $16.015,99$ & 36 & 39 & $16.507,51$ \\
\hline $31 a$ & 39 & $12.979,06$ & 33 & 45 & $7.893 .094,00$ & 36 & 40 & $20.999,44$ \\
\hline $31 a$ & 40 & $20.042,76$ & 33 & 46 & $17.207,73$ & 36 & 41 & $20.736,61$ \\
\hline $31 a$ & 41 & $22.395,54$ & 33 & 47 & $17.495,72$ & 36 & 42 & $46.111,81$ \\
\hline $31 a$ & 42 & $34.401,91$ & 33 & $31 \mathrm{c}$ & $15.649,58$ & 36 & 43 & $28.126,45$ \\
\hline $31 a$ & 43 & $27.169,85$ & 33 & $31 b$ & $15.760,00$ & 36 & 44 & $26.491,22$ \\
\hline $31 a$ & 44 & $25.534,62$ & 34 & 35 & $2.967 .279,00$ & 36 & 45 & $15.801,69$ \\
\hline $31 a$ & 45 & $14.844,99$ & 34 & 36 & $41.865,26$ & 36 & 46 & $20.624,96$ \\
\hline $31 a$ & 46 & $16.728,70$ & 34 & 37 & $42.242,65$ & 36 & 47 & $20.912,96$ \\
\hline $31 a$ & 47 & $17.016,70$ & 34 & 38 & $17.965,04$ & 36 & $31 c$ & $25.119,90$ \\
\hline 32 & 33 & $2.802,76$ & 34 & 39 & $38.423,29$ & 36 & $31 b$ & $14.945,55$ \\
\hline 32 & 34 & $28.273,88$ & 34 & 40 & $34.896,34$ & 37 & 38 & $31.467,95$ \\
\hline 32 & 35 & $30.591,45$ & 34 & 41 & $26.428,07$ & 37 & 39 & $22.713,75$ \\
\hline 32 & 36 & $18.936,24$ & 34 & 42 & $6.039 .946,00$ & 37 & 40 & $29.777,19$ \\
\hline 32 & 37 & $30.244,92$ & 34 & 43 & $43.102,22$ & 37 & 41 & $32.130,27$ \\
\hline 32 & 38 & $45.629,71$ & 34 & 44 & $41.467,03$ & 37 & 42 & $38.310,61$ \\
\hline 32 & 39 & $11.359,15$ & 34 & 45 & $33.344,45$ & 37 & 43 & $36.904,14$ \\
\hline 32 & 40 & $7.820 .097,00$ & 34 & 46 & $42.658,59$ & 37 & 44 & $35.268,94$ \\
\hline 32 & 41 & $3.094 .123,00$ & 34 & 47 & $42.946,55$ & 37 & 45 & $24.579,55$ \\
\hline 32 & 42 & $33.705,14$ & 34 & $31 \mathrm{c}$ & $41.100,79$ & 37 & 46 & $26.304,02$ \\
\hline 32 & 43 & $16.026,40$ & 34 & $31 b$ & $41.210,98$ & 37 & 47 & $26.592,02$ \\
\hline 32 & 44 & $14.391,18$ & 35 & 36 & $42.875,13$ & 37 & $31 c$ & $30.798,96$ \\
\hline 32 & 45 & $6.280,03$ & 35 & 37 & $39.350,00$ & 37 & $31 b$ & $20.624,61$ \\
\hline 32 & 46 & $15.594,66$ & 35 & 38 & $15.161,76$ & 38 & 39 & $54.138,79$ \\
\hline 32 & 47 & $15.882,66$ & 35 & 39 & $40.740,86$ & 38 & 40 & $52.252,59$ \\
\hline 32 & $31 c$ & $14.024,79$ & 35 & 40 & $37.213,88$ & 38 & 41 & $43.783,90$ \\
\hline 32 & $31 b$ & $14.146,94$ & 35 & 41 & $28.745,64$ & 38 & 42 & $11.925,06$ \\
\hline
\end{tabular}

Continua... 


\begin{tabular}{|c|c|c|c|c|c|}
\hline \multicolumn{2}{|c|}{ Nodo } & \multirow{2}{*}{$\begin{array}{c}\text { Enlace } \\
60.458,51\end{array}$} & \multicolumn{2}{|c|}{ Nodo } & \multirow{2}{*}{$\begin{array}{c}\text { Enlace } \\
17.768,01\end{array}$} \\
\hline 38 & 43 & & 41 & 47 & \\
\hline 38 & 44 & $58.823,31$ & 41 & $31 c$ & $15.921,88$ \\
\hline 38 & 45 & $50.700,73$ & 41 & $31 b$ & $16.032,30$ \\
\hline 38 & 46 & $57.728,68$ & 42 & 43 & $48.533,39$ \\
\hline 38 & 47 & $58.016,64$ & 42 & 44 & $46.898,20$ \\
\hline 38 & $31 c$ & $58.457,07$ & 42 & 45 & $38.775,61$ \\
\hline 38 & $31 b$ & $52.049,78$ & 42 & 46 & $48.089,75$ \\
\hline 39 & 40 & $10.891,93$ & 42 & 47 & $48.377,72$ \\
\hline 39 & 41 & $13.244,51$ & 42 & $31 c$ & $46.531,95$ \\
\hline 39 & 42 & $43.855,47$ & 42 & $31 b$ & $45.450,74$ \\
\hline 39 & 43 & $18.018,91$ & 43 & 44 & $1.766 .345,00$ \\
\hline 39 & 44 & $16.383,68$ & 43 & 45 & $12.939,72$ \\
\hline 39 & 45 & $5.694 .016,00$ & 43 & 46 & $15.712,78$ \\
\hline 39 & 46 & $4.268 .595,00$ & 43 & 47 & $17.302,76$ \\
\hline 39 & 47 & $4.556 .584,00$ & 43 & $31 c$ & $11.030,14$ \\
\hline 39 & $31 \mathrm{c}$ & $8.763,47$ & 43 & $31 b$ & $20.806,63$ \\
\hline 39 & $31 \mathrm{~b}$ & $4.876 .434,00$ & 44 & 45 & $11.304,46$ \\
\hline 40 & 41 & $9.717 .146,00$ & 44 & 46 & $14.077,51$ \\
\hline 40 & 42 & $40.328,06$ & 44 & 47 & $15.667,49$ \\
\hline 40 & 43 & $14.773,56$ & 44 & $31 c$ & $9.394 .862,00$ \\
\hline 40 & 44 & $13.138,33$ & 44 & $31 b$ & $19.171,37$ \\
\hline 40 & 45 & $5.812 .799,00$ & 45 & 46 & $9.929 .471,00$ \\
\hline 40 & 46 & $15.127,43$ & 45 & 47 & $10.217,47$ \\
\hline 40 & 47 & $15.415,43$ & 45 & $31 \mathrm{c}$ & $10.938,08$ \\
\hline 40 & $31 c$ & $12.771,98$ & 45 & $31 b$ & $8.481 .756,00$ \\
\hline 40 & $31 b$ & $13.679,71$ & 46 & 47 & $1.900 .659,00$ \\
\hline 41 & 42 & $31.859,33$ & 46 & $31 c$ & $4.682 .564,00$ \\
\hline 41 & 43 & $17.923,51$ & 46 & $31 b$ & $5.679 .284,00$ \\
\hline 41 & 44 & $16.288,28$ & 47 & $31 c$ & $6.272 .508,00$ \\
\hline 41 & 45 & $8.165 .385,00$ & 47 & $31 b$ & $5.967 .273,00$ \\
\hline 41 & 46 & $17.480,02$ & & & \\
\hline
\end{tabular}

Tabla 11.2: Conexiones potenciales en Río Ratones. Fuente: Elaboración propia. 


\subsection{CONEXIONES POTENCIALES EN ITACORUBI}

\begin{tabular}{|c|c|c|c|c|c|c|c|c|}
\hline \multicolumn{2}{|c|}{ Nodo } & \multirow{2}{*}{$\begin{array}{c}\text { Enlace } \\
14.357,90\end{array}$} & \multicolumn{2}{|c|}{ Nodo } & \multirow{2}{*}{$\begin{array}{c}\text { Enlace } \\
13.287,03\end{array}$} & \multicolumn{2}{|c|}{ Nodo } & \multirow{2}{*}{$\begin{array}{c}\text { Enlace } \\
56.276,29\end{array}$} \\
\hline 1 & 2 & & 3 & 4 & & 5 & 10 & \\
\hline 1 & 3 & $31.556,43$ & 3 & 5 & $34.645,14$ & 5 & 11 & $55.552,32$ \\
\hline 1 & 4 & $44.585,27$ & 3 & 6 & $47.058,53$ & 5 & 12 & $57.392,78$ \\
\hline 1 & 5 & $3.828 .614,00$ & 3 & 7 & $64.124,13$ & 5 & 13 & $52.803,23$ \\
\hline 1 & 6 & $31.787,00$ & 3 & 8 & $56.107,58$ & 5 & 14 & $51.686,84$ \\
\hline 1 & 7 & $86.659,84$ & 3 & 9 & $54.205,24$ & 5 & 15 & $77.813,80$ \\
\hline 1 & 8 & $76.044,49$ & 3 & 10 & $77.090,63$ & 5 & 16 & $4.943 .642,00$ \\
\hline 1 & 9 & $74.171,45$ & 3 & 11 & $76.211,12$ & 5 & 17 & $19.336,90$ \\
\hline 1 & 10 & $52.538,46$ & 3 & 12 & $74.600,34$ & 5 & 18 & $24.871,79$ \\
\hline 1 & 11 & $51.814,48$ & 3 & 13 & $79.313,30$ & 5 & 19 & $33.095,44$ \\
\hline 1 & 12 & $53.654,95$ & 3 & 14 & $43.886,56$ & 5 & 20 & $36.751,37$ \\
\hline 1 & 13 & $49.065,40$ & 3 & 15 & $70.904,41$ & 6 & 7 & $82.955,48$ \\
\hline 1 & 14 & $48.066,36$ & 3 & 16 & $32.757,70$ & 6 & 8 & $89.559,96$ \\
\hline 1 & 15 & $74.075,95$ & 3 & 17 & $47.164,82$ & 6 & 9 & $87.657,62$ \\
\hline 1 & 16 & $1.309,03$ & 3 & 18 & $43.094,25$ & 6 & 10 & $84.234,44$ \\
\hline 1 & 17 & $15.716,22$ & 3 & 19 & $60.923,48$ & 6 & 11 & $83.510,47$ \\
\hline 1 & 18 & $21.251,12$ & 3 & 20 & $31.647,61$ & 6 & 12 & $85.350,94$ \\
\hline 1 & 19 & $29.474,78$ & 4 & 5 & $45.490,00$ & 6 & 13 & $80.761,41$ \\
\hline 1 & 20 & $33.131,14$ & 4 & 6 & $33.804,64$ & 6 & 14 & $31.484,11$ \\
\hline 2 & 3 & $45.914,35$ & 4 & 7 & $77.317,44$ & 6 & 15 & $104.356,80$ \\
\hline 2 & 4 & $42.169,23$ & 4 & 8 & $69.300,88$ & 6 & 16 & $32.901,84$ \\
\hline 2 & 5 & $17.680,36$ & 4 & 9 & $67.398,54$ & 6 & 17 & $31.318,30$ \\
\hline 2 & 6 & $36.685,91$ & 4 & 10 & $90.283,93$ & 6 & 18 & $24.357,65$ \\
\hline 2 & 7 & $90.963,07$ & 4 & 11 & $89.404,41$ & 6 & 19 & $45.584,70$ \\
\hline 2 & 8 & $89.932,47$ & 4 & 12 & $87.793,63$ & 6 & 20 & $18.228,90$ \\
\hline 2 & 9 & $88.059,42$ & 4 & 13 & $92.506,59$ & 7 & 8 & $10.712,47$ \\
\hline 2 & 10 & $66.426,42$ & 4 & 14 & $30.632,67$ & 7 & 9 & $12.517,90$ \\
\hline 2 & 11 & $65.702,45$ & 4 & 15 & $84.097,76$ & 7 & 10 & $35.736,79$ \\
\hline 2 & 12 & $67.542,92$ & 4 & 16 & $45.786,59$ & 7 & 11 & $34.857,27$ \\
\hline 2 & 13 & $62.953,37$ & 4 & 17 & $36.801,21$ & 7 & 12 & $33.246,49$ \\
\hline 2 & 14 & $39.143,66$ & 4 & 18 & $29.840,97$ & 7 & 13 & $37.959,47$ \\
\hline 2 & 15 & $87.963,99$ & 4 & 19 & $51.067,48$ & 7 & 14 & $75.454,72$ \\
\hline 2 & 16 & $14.991,30$ & 4 & 20 & $18.393,73$ & 7 & 15 & $25.232,09$ \\
\hline 2 & 17 & $11.557,66$ & 5 & 6 & $27.958,39$ & 7 & 16 & $85.729,26$ \\
\hline 2 & 18 & $12.949,16$ & 5 & 7 & $90.397,68$ & 7 & 17 & $85.593,79$ \\
\hline 2 & 19 & $25.824,11$ & 5 & 8 & $79.782,33$ & 7 & 18 & $78.633,98$ \\
\hline 2 & 20 & $24.208,21$ & 5 & 9 & $77.909,28$ & 7 & 19 & $99.860,07$ \\
\hline
\end{tabular}

Continua... 


\begin{tabular}{|c|c|c|c|c|c|}
\hline \multicolumn{2}{|c|}{ Nodo } & \multirow{2}{*}{$\begin{array}{c}\text { Enlace } \\
67.152,15\end{array}$} & \multicolumn{2}{|c|}{ Nodo } & \multirow{2}{*}{$\begin{array}{c}\text { Enlace } \\
71.139,34\end{array}$} \\
\hline 7 & 20 & & 11 & 18 & \\
\hline 8 & 9 & $1.902 .406,00$ & 11 & 19 & $79.363,87$ \\
\hline 8 & 10 & $25.121,30$ & 11 & 20 & $83.018,67$ \\
\hline 8 & 11 & $24.241,77$ & 12 & 13 & $4.954 .495,00$ \\
\hline 8 & 12 & $22.630,99$ & 12 & 14 & $99.795,73$ \\
\hline 8 & 13 & $27.344,10$ & 12 & 15 & $28.581,04$ \\
\hline 8 & 14 & $85.995,41$ & 12 & 16 & $52.724,46$ \\
\hline 8 & 15 & $14.796,87$ & 12 & 17 & $67.445,68$ \\
\hline 8 & 16 & $75.114,09$ & 12 & 18 & $72.979,82$ \\
\hline 8 & 17 & $89.835,36$ & 12 & 19 & $81.204,34$ \\
\hline 8 & 18 & $85.442,88$ & 12 & 20 & $84.859,15$ \\
\hline 8 & 19 & $103.594,00$ & 13 & 14 & $95.206,20$ \\
\hline 8 & 20 & $73.996,20$ & 13 & 15 & $25.375,42$ \\
\hline 9 & 10 & $23.248,19$ & 13 & 16 & $48.134,83$ \\
\hline 9 & 11 & $22.368,66$ & 13 & 17 & $62.856,05$ \\
\hline 9 & 12 & $20.757,87$ & 13 & 18 & $68.390,19$ \\
\hline 9 & 13 & $25.470,98$ & 13 & 19 & $76.614,72$ \\
\hline 9 & 14 & $84.093,06$ & 13 & 20 & $80.269,52$ \\
\hline 9 & 15 & $16.699,27$ & 14 & 15 & $81.668,41$ \\
\hline 9 & 16 & $73.240,98$ & 14 & 16 & $47.071,51$ \\
\hline 9 & 17 & $87.962,25$ & 14 & 17 & $33.776,05$ \\
\hline 9 & 18 & $83.540,47$ & 14 & 18 & $26.815,43$ \\
\hline 9 & 19 & $101.720,90$ & 14 & 19 & $48.042,32$ \\
\hline 9 & 20 & $72.093,80$ & 14 & 20 & $14.935,36$ \\
\hline 10 & 11 & $8.878 .123,00$ & 15 & 16 & $73.145,41$ \\
\hline 10 & 12 & $2.731 .731,00$ & 15 & 17 & $87.866,68$ \\
\hline 10 & 13 & $3.837 .974,00$ & 15 & 18 & $93.400,82$ \\
\hline 10 & 14 & $98.679,23$ & 15 & 19 & $101.625,30$ \\
\hline 10 & 15 & $27.464,52$ & 15 & 20 & $88.793,13$ \\
\hline 10 & 16 & $51.607,94$ & 16 & 17 & $14.721,37$ \\
\hline 10 & 17 & $66.329,16$ & 16 & 18 & $20.256,27$ \\
\hline 10 & 18 & $71.863,30$ & 16 & 19 & $28.479,93$ \\
\hline 10 & 19 & $80.087,83$ & 16 & 20 & $32.136,34$ \\
\hline 10 & 20 & $83.742,63$ & 17 & 18 & $6.960 .451,00$ \\
\hline 11 & 12 & $1.852 .203,00$ & 17 & 19 & $14.418,73$ \\
\hline 11 & 13 & $3.114 .009,00$ & 17 & 20 & $18.840,50$ \\
\hline 11 & 14 & $97.955,26$ & 18 & 19 & $21.226,87$ \\
\hline 11 & 15 & $26.740,55$ & 18 & 20 & $11.879,99$ \\
\hline 11 & 16 & $50.883,98$ & 19 & 20 & $33.107,12$ \\
\hline 11 & 17 & $65.605,20$ & & & \\
\hline
\end{tabular}

Tabla 11.3: Conexiones potenciales en Itacorubi. Fuente: Elaboración propia. 


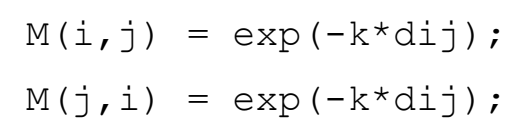

end

\subsubsection{Outflux Potential}

웅

o Combining different metrics to measure the ecological connectivity of two mangrove

o landscapes in the Municipality of Florianópolis, Southern Brazil.

o Author: Bárbara H. A. d'Acampora, Ester Higueras, Emilia Román $\%$

$\frac{\circ}{0}$

o Codes by: Cleiton Guollo Taufemback 
음 Date: Jun/2017

응

function output = Outfluxpotential ( nodes, connection, distance, prob )

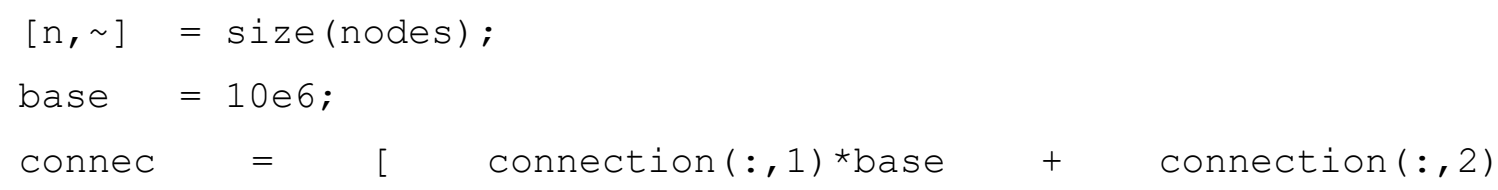




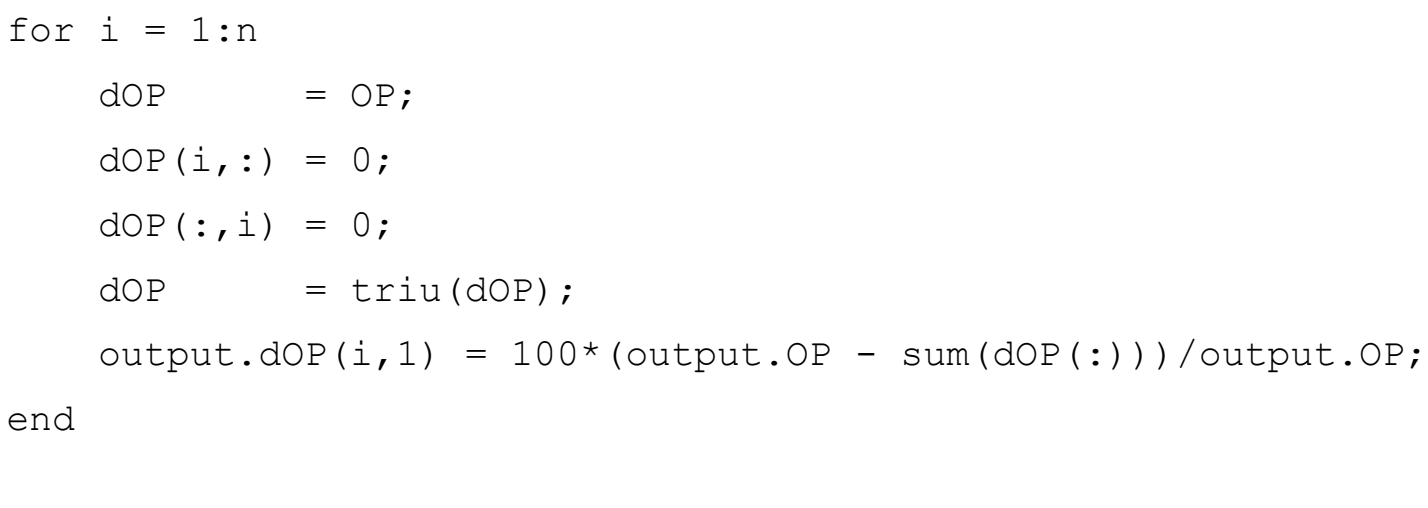

\subsubsection{Metapopulation Capacity}

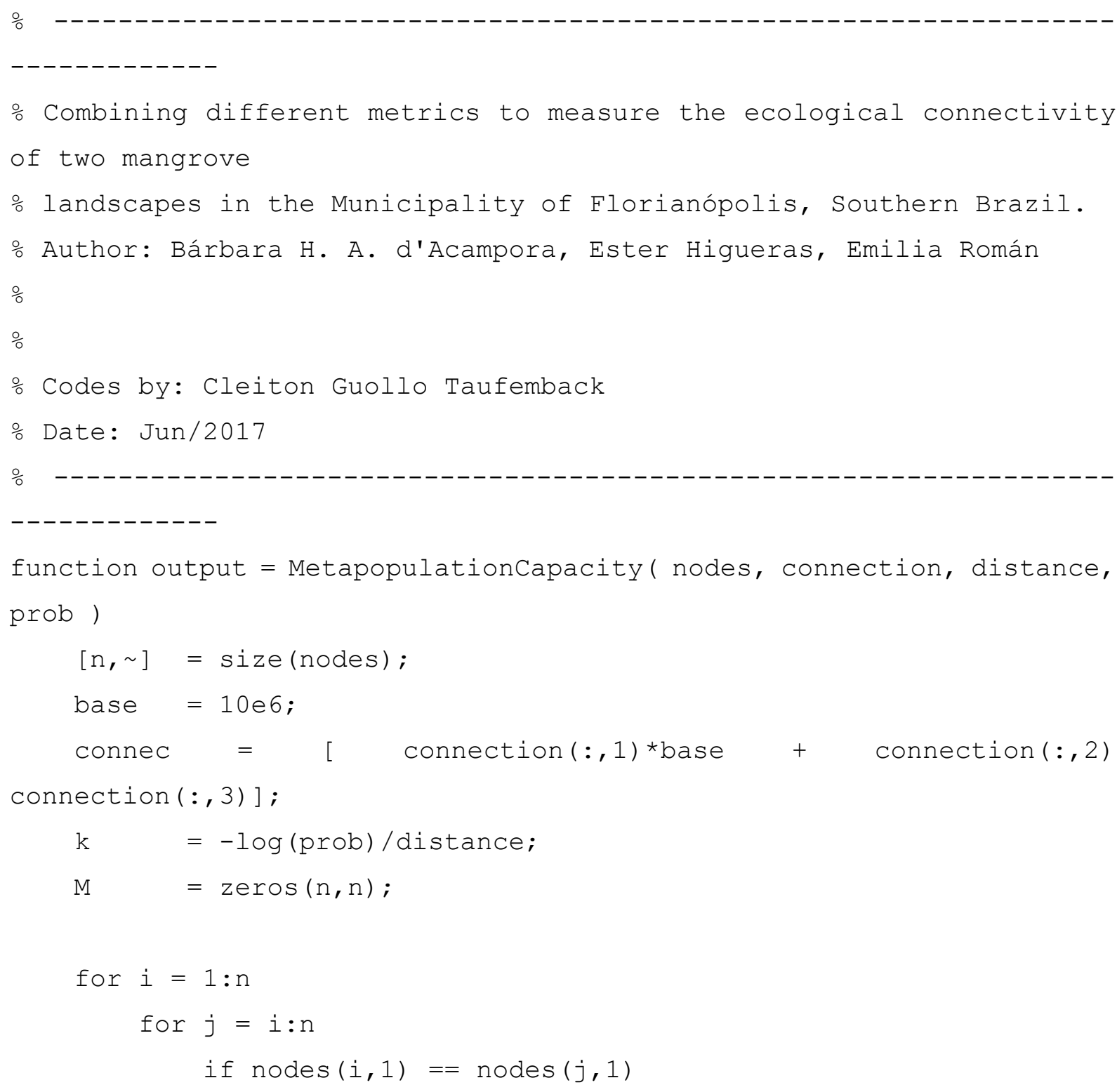


PARTE V. Capítulo 11. ANEXOS

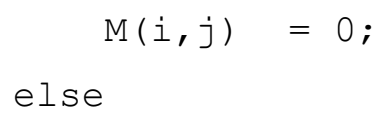

dij = connec $(\operatorname{connec}(:, 1)==\operatorname{nodes}(i, 1) *$ base + $\operatorname{nodes}(j, 1), 2)$;

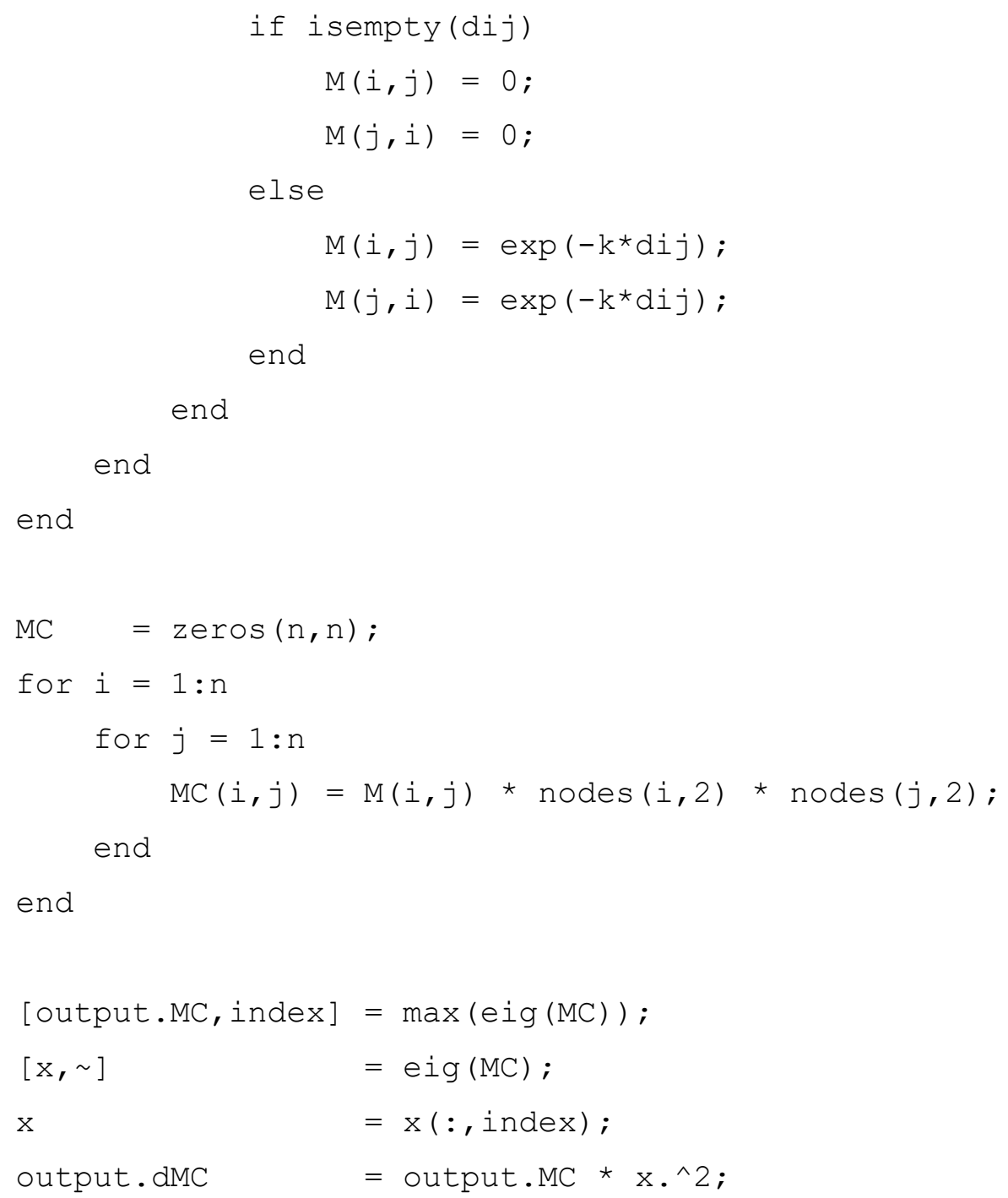

end

\subsubsection{Normalización}

o Combining different metrics to measure the ecological connectivity of two mangrove 
- landscapes in the Municipality of Florianópolis, Southern Brazil.

o Author: Bárbara H. A. d'Acampora, Ester Higueras, Emilia Román $\circ$

잉

\% Codes by: Cleiton Guollo Taufemback

\% Date: Jun/2017

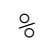

function $\mathrm{Z}=$ Normalization ( $\mathrm{X}$ )

$$
\begin{aligned}
& \mathrm{X}=\mathrm{X}-\min (\mathrm{X}) ; \\
& \mathrm{Z}=\mathrm{x} / \max (\mathrm{X}) ;
\end{aligned}
$$

end 


\subsection{VALORES DE LOS NODOS PARA CADA MÉTRICA DE CONECTIVIDAD ECOLÓGICA EN RÍO RATONES}

\begin{tabular}{|c|c|c|c|c|c|c|}
\hline Nodo & $\mathbf{F}$ & AWF & PC & IP & OP & MC \\
\hline 1 & 4,808 & 4,544 & 0,515 & 2,349 & 1,680 & $6,894 \mathrm{E}+10$ \\
\hline 2 & 1,286 & 0,304 & 0,587 & 1,732 & 2,815 & 2,916E-03 \\
\hline 3 & 1,579 & 0,846 & 0,164 & 0,933 & 1,189 & 2,598E-01 \\
\hline 4 & 0,796 & 0,026 & 0,007 & 0,188 & 0,223 & $6,941 \mathrm{E}+02$ \\
\hline 5 & 0,812 & 0,028 & 0,004 & 0,155 & 0,136 & $9,069 \mathrm{E}+02$ \\
\hline 6 & 7,131 & 1,267 & 0,129 & 1,658 & 0,684 & $4,192 E+09$ \\
\hline 7 & 5,831 & 0,459 & 0,044 & 1,883 & 0,200 & $4,085 E+08$ \\
\hline 8 & 5,059 & 1,717 & 0,172 & 2,185 & 0,535 & $9,555 \mathrm{E}+08$ \\
\hline 9 & 2,328 & 0,162 & 0,018 & 0,472 & 0,215 & $7,918 \mathrm{E}+06$ \\
\hline 10 & 2,855 & 0,973 & 0,098 & 1,648 & 0,321 & $1,526 \mathrm{E}+08$ \\
\hline 11 & 8,383 & 0,432 & 0,041 & 3,277 & 0,131 & $8,137 \mathrm{E}+07$ \\
\hline 12 & 1,520 & 0,405 & 0,046 & 0,698 & 0,338 & $2,846 \mathrm{E}+08$ \\
\hline 13 & 0,809 & 0,115 & 0,015 & 0,337 & 0,222 & $3,214 \mathrm{E}+07$ \\
\hline 14 & 0,019 & 0,007 & 0,003 & 0,124 & 0,145 & $1,100 \mathrm{E}+02$ \\
\hline 15 & 4,735 & 0,557 & 0,057 & 1,080 & 0,376 & $5,855 \mathrm{E}+08$ \\
\hline 16 & 0,175 & 0,001 & 0,000 & 0,032 & 0,035 & $4,887 E+01$ \\
\hline 17 & 0,431 & 0,022 & 0,008 & 0,210 & 0,244 & $5,851 \mathrm{E}+05$ \\
\hline 18 & 2,063 & 0,581 & 0,096 & 2,140 & 0,127 & $3,060 \mathrm{E}+06$ \\
\hline 19 & 1,091 & 0,146 & 0,015 & 0,607 & 0,106 & $1,610 \mathrm{E}+05$ \\
\hline 20 & 2,579 & 0,799 & 0,086 & 1,085 & 0,448 & $1,458 \mathrm{E}+09$ \\
\hline 21 & 4,599 & 0,112 & 0,011 & 1,383 & 0,099 & $2,214 \mathrm{E}+07$ \\
\hline 22 & 5,809 & 1,610 & 0,155 & 4,803 & 0,301 & $4,852 \mathrm{E}+08$ \\
\hline 23 & 1,046 & 0,204 & 0,021 & 0,707 & 0,134 & $1,461 \mathrm{E}+08$ \\
\hline 24 & 6,139 & 0,542 & 0,052 & 3,967 & 0,177 & $1,023 E+09$ \\
\hline 25 & 2,871 & 2,054 & 0,212 & 2,026 & 0,579 & $1,477 \mathrm{E}+10$ \\
\hline 26 & 1,296 & 0,104 & 0,011 & 0,446 & 0,121 & $2,772 \mathrm{E}+07$ \\
\hline 27 & 1,827 & 1,048 & 0,135 & 1,089 & 0,678 & $3,526 \mathrm{E}+09$ \\
\hline 28 & 11,607 & 64,428 & 24,872 & 21,949 & 28,589 & $5,443 \mathrm{E}+12$ \\
\hline 29 & 13,246 & 38,902 & 4,800 & 6,266 & 11,462 & $4,125 E+12$ \\
\hline 30 & 0,179 & 0,014 & 0,003 & 0,110 & 0,178 & $5,118 \mathrm{E}+05$ \\
\hline $31 a$ & 1,408 & 1,900 & 26,751 & 14,269 & 16,241 & $2,244 \mathrm{E}+09$ \\
\hline $31 b$ & 4,041 & 10,517 & 12,977 & 13,482 & 10,469 & $1,138 \mathrm{E}+11$ \\
\hline $31 c$ & 5,550 & 17,926 & 31,861 & 25,577 & 16,783 & $2,277 \mathrm{E}+11$ \\
\hline 32 & 12,092 & 0,352 & 0,034 & 0,656 & 3,811 & $3,155 E+08$ \\
\hline 33 & 8,763 & 0,477 & 0,046 & 0,543 & 2,220 & $5,231 \mathrm{E}+08$ \\
\hline 34 & 2,296 & 0,134 & 0,016 & 0,371 & 0,266 & $1,497 \mathrm{E}+01$ \\
\hline 35 & 3,437 & 0,406 & 0,044 & 0,748 & 0,386 & $4,524 \mathrm{E}+00$ \\
\hline
\end{tabular}

Continua... 


\begin{tabular}{|c|c|c|c|c|c|c|}
\hline Nodo & F & AWF & PC & IP & OP & MC \\
\hline 36 & 0,639 & 0,084 & 0,014 & 0,225 & 0,340 & $6,846 \mathrm{E}+05$ \\
\hline 37 & 0,182 & 0,034 & 0,003 & 0,031 & 0,440 & $2,460 \mathrm{E}+03$ \\
\hline 38 & 1,564 & 0,101 & 0,010 & 0,094 & 0,621 & $2,029 \mathrm{E}-05$ \\
\hline 39 & 7,936 & 2,299 & 0,228 & 2,493 & 1,097 & $1,893 \mathrm{E}+09$ \\
\hline 40 & 8,215 & 0,468 & 0,045 & 0,518 & 5,010 & $6,558 \mathrm{E}+08$ \\
\hline 41 & 8,220 & 4,800 & 0,559 & 2,010 & 2,945 & $6,356 \mathrm{E}+10$ \\
\hline 42 & 2,846 & 1,173 & 0,708 & 2,719 & 2,541 & $4,870 \mathrm{E}+01$ \\
\hline 43 & 3,070 & 0,055 & 0,006 & 0,283 & 0,178 & $1,650 \mathrm{E}+06$ \\
\hline 44 & 3,439 & 0,063 & 0,006 & 0,454 & 0,228 & $2,181 \mathrm{E}+06$ \\
\hline 45 & 10,138 & 29,109 & 3,990 & 7,726 & 6,734 & $1,898 \mathrm{E}+12$ \\
\hline 46 & 7,242 & 7,249 & 1,125 & 3,921 & 1,586 & $8,796 \mathrm{E}+09$ \\
\hline 47 & 6,014 & 0,444 & 0,043 & 2,062 & 0,684 & $2,801 \mathrm{E}+07$ \\
\hline
\end{tabular}

Tabla 11.4: Valores de los nodos para cada métrica de conectividad ecológica en Río Ratones. Fuente: Elaboración propia. 


\subsection{VALORES DE LOS NODOS PARA CADA MÉTRICAS DE CONECTIVIDAD ECOLÓGICA EN ITACORUBI}

\begin{tabular}{|c|c|c|c|c|c|c|}
\hline Nodo & F & AWF & PC & IP & OP & MC \\
\hline 1 & 21,691 & 42,305 & 4,005 & 10,890 & 15,966 & $1,499 \mathrm{E}+11$ \\
\hline 2 & 0,778 & 0,113 & 0,004 & 0,496 & 0,162 & $7,397 \mathrm{E}+05$ \\
\hline 3 & 0,175 & 0,015 & 0,021 & 0,765 & 0,748 & $1,696 \mathrm{E}+01$ \\
\hline 4 & 0,201 & 0,110 & 0,059 & 1,298 & 1,240 & $3,850 \mathrm{E}+05$ \\
\hline 5 & 10,045 & 0,956 & 0,031 & 0,741 & 2,232 & $8,011 \mathrm{E}+07$ \\
\hline 6 & 0,032 & 0,019 & 0,002 & 0,254 & 0,211 & $1,619 \mathrm{E}+04$ \\
\hline 7 & 0,692 & 0,003 & 0,001 & 0,169 & 0,163 & $8,848 \mathrm{E}-13$ \\
\hline 8 & 12,957 & 0,064 & 0,005 & 0,409 & 0,466 & $3,255 \mathrm{E}-14$ \\
\hline 9 & 12,693 & 0,062 & 0,003 & 0,262 & 0,325 & $4,101 \mathrm{E}-14$ \\
\hline 10 & 33,206 & 0,035 & 0,002 & 0,248 & 0,297 & $1,150 \mathrm{E}-08$ \\
\hline 11 & 38,620 & 0,035 & 0,001 & 0,231 & 0,262 & $1,053 \mathrm{E}-08$ \\
\hline 12 & 25,674 & 0,022 & 0,001 & 0,179 & 0,196 & $2,385 \mathrm{E}-09$ \\
\hline 13 & 17,828 & 0,012 & 0,001 & 0,118 & 0,141 & $4,295 \mathrm{E}-08$ \\
\hline 14 & 0,096 & 0,064 & 0,004 & 0,352 & 0,226 & $1,706 \mathrm{E}+05$ \\
\hline 15 & 0,154 & 0,002 & 0,014 & 0,643 & 0,629 & $2,747 \mathrm{E}-14$ \\
\hline 16 & 19,647 & 41,532 & 1,703 & 6,071 & 8,647 & $1,494 \mathrm{E}+11$ \\
\hline 17 & 2,524 & 22,867 & 1,110 & 6,411 & 3,602 & $3,174 \mathrm{E}+10$ \\
\hline 18 & 2,394 & 57,112 & 57,913 & 43,657 & 39,994 & $1,038 \mathrm{E}+11$ \\
\hline 19 & 0,126 & 0,043 & 0,016 & 0,644 & 0,658 & $6,623 \mathrm{E}+04$ \\
\hline 20 & 0,468 & 34,630 & 38,225 & 33,117 & 32,411 & $7,176 \mathrm{E}+10$ \\
\hline
\end{tabular}

Tabla 11.5: Valores de los nodos para cada métrica de conectividad ecológica en Itacorubi. Fuente: Elaboración propia. 


\subsection{VALORES NORMALIZADOS DE LOS NODOS (ENTRE 0 Y 1) PARA CADA MÉTRICA DE CONECTIVIDAD ECOLÓGICA EN RÍO RATONES}

\begin{tabular}{|c|c|c|c|c|c|c|}
\hline Nodo & $F$ & AWF & PC & IP & OP & MC \\
\hline 1 & 0,362 & 7,051E-02 & 1,616E-02 & $9,073 \mathrm{E}-02$ & 5,760E-02 & 1,267E-02 \\
\hline 2 & 0,096 & 4,709E-03 & 1,843E-02 & 6,657E-02 & 9,735E-02 & $5,320 \mathrm{E}-16$ \\
\hline 3 & 0,118 & 1,311E-02 & 5,154E-03 & 3,528E-02 & 4,042E-02 & $4,773 \mathrm{E}-14$ \\
\hline 4 & 0,059 & 3,929E-04 & $2,002 \mathrm{E}-04$ & 6,139E-03 & 6,573E-03 & $1,275 \mathrm{E}-10$ \\
\hline 5 & 0,060 & 4,217E-04 & 1,165E-04 & 4,837E-03 & 3,551E-03 & $1,666 \mathrm{E}-10$ \\
\hline 6 & 0,538 & 1,966E-02 & 4,056E-03 & 6,367E-02 & 2,272E-02 & 7,703E-04 \\
\hline 7 & 0,439 & 7,115E-03 & 1,388E-03 & 7,248E-02 & 5,774E-03 & 7,506E-05 \\
\hline 8 & 0,381 & 2,664E-02 & 5,405E-03 & 8,432E-02 & 1,751E-02 & 1,756E-04 \\
\hline 9 & 0,175 & $2,500 \mathrm{E}-03$ & 5,436E-04 & 1,725E-02 & 6,306E-03 & 1,455E-06 \\
\hline 10 & 0,214 & 1,509E-02 & $3,058 \mathrm{E}-03$ & 6,330E-02 & 1,003E-02 & 2,804E-05 \\
\hline 11 & 0,632 & 6,686E-03 & 1,289E-03 & 1,271E-01 & 3,354E-03 & 1,495E-05 \\
\hline 12 & 0,113 & $6,273 \mathrm{E}-03$ & 1,447E-03 & 2,609E-02 & 1,061E-02 & 5,228E-05 \\
\hline 13 & 0,060 & 1,771E-03 & 4,635E-04 & 1,197E-02 & 6,560E-03 & 5,904E-06 \\
\hline 14 & 0,000 & $1,044 \mathrm{E}-04$ & 8,775E-05 & 3,634E-03 & 3,847E-03 & $2,021 \mathrm{E}-11$ \\
\hline 15 & 0,357 & 8,633E-03 & 1,785E-03 & 4,105E-02 & 1,196E-02 & 1,076E-04 \\
\hline 16 & 0,012 & $0,000 \mathrm{E}+00$ & $0,000 \mathrm{E}+00$ & 2,788E-05 & $0,000 \mathrm{E}+00$ & 8,978E-12 \\
\hline 17 & 0,031 & 3,349E-04 & $2,465 \mathrm{E}-04$ & $7,006 \mathrm{E}-03$ & $7,325 \mathrm{E}-03$ & $1,075 \mathrm{E}-07$ \\
\hline 18 & 0,154 & $9,006 \mathrm{E}-03$ & $3,010 \mathrm{E}-03$ & 8,252E-02 & 3,233E-03 & 5,622E-07 \\
\hline 19 & 0,081 & $2,248 \mathrm{E}-03$ & 4,549E-04 & $2,254 \mathrm{E}-02$ & 2,496E-03 & 2,958E-08 \\
\hline 20 & 0,194 & 1,239E-02 & $2,704 \mathrm{E}-03$ & 4,124E-02 & $1,448 \mathrm{E}-02$ & 2,679E-04 \\
\hline 21 & 0,346 & $1,725 \mathrm{E}-03$ & 3,303E-04 & 5,293E-02 & 2,237E-03 & 4,067E-06 \\
\hline 22 & 0,438 & $2,498 \mathrm{E}-02$ & 4,844E-03 & 1,868E-01 & 9,332E-03 & 8,915E-05 \\
\hline 23 & 0,078 & 3,151E-03 & 6,397E-04 & 2,646E-02 & 3,464E-03 & 2,684E-05 \\
\hline 24 & 0,463 & 8,401E-03 & $1,620 \mathrm{E}-03$ & $1,540 \mathrm{E}-01$ & 4,976E-03 & 1,879E-04 \\
\hline 25 & 0,216 & 3,186E-02 & 6,648E-03 & 7,809E-02 & 1,904E-02 & 2,714E-03 \\
\hline 26 & 0,097 & 1,609E-03 & 3,317E-04 & 1,622E-02 & 3,021E-03 & 5,094E-06 \\
\hline 27 & 0,137 & 1,626E-02 & 4,218E-03 & $4,140 \mathrm{E}-02$ & $2,251 \mathrm{E}-02$ & $6,479 \mathrm{E}-04$ \\
\hline 28 & 0,876 & $1,000 \mathrm{E}+00$ & 7,807E-01 & 8,580E-01 & $1,000 E+00$ & $1,000 \mathrm{E}+00$ \\
\hline 29 & 1,000 & $6,038 \mathrm{E}-01$ & 1,507E-01 & $2,440 \mathrm{E}-01$ & 4,002E-01 & 7,579E-01 \\
\hline 30 & 0,012 & 2,031E-04 & $1,033 \mathrm{E}-04$ & $3,058 \mathrm{E}-03$ & 4,998E-03 & $9,403 \mathrm{E}-08$ \\
\hline $31 a$ & 0,105 & 2,948E-02 & 8,396E-01 & 5,573E-01 & 5,676E-01 & 4,123E-04 \\
\hline $31 b$ & 0,304 & 1,632E-01 & 4,073E-01 & 5,265E-01 & 3,654E-01 & $2,090 \mathrm{E}-02$ \\
\hline $31 c$ & 0,418 & 2,782E-01 & $1,000 \mathrm{E}+00$ & $1,000 \mathrm{E}+00$ & 5,865E-01 & 4,185E-02 \\
\hline 32 & 0,913 & 5,451E-03 & 1,049E-03 & $2,445 \mathrm{E}-02$ & 1,323E-01 & 5,797E-05 \\
\hline 33 & 0,661 & 7,396E-03 & $1,440 \mathrm{E}-03$ & $2,002 \mathrm{E}-02$ & 7,653E-02 & 9,611E-05 \\
\hline 34 & 0,172 & $2,072 \mathrm{E}-03$ & 5,019E-04 & 1,328E-02 & $8,090 \mathrm{E}-03$ & $2,750 \mathrm{E}-12$ \\
\hline 35 & 0,258 & 6,296E-03 & 1,378E-03 & 2,806E-02 & 1,229E-02 & $8,312 \mathrm{E}-13$ \\
\hline
\end{tabular}

Continua... 


\begin{tabular}{|c|c|c|c|c|c|c|}
\hline Nodo & $\mathbf{F}$ & AWF & PC & IP & OP & MC \\
\hline 36 & 0,047 & $1,299 \mathrm{E}-03$ & $4,207 \mathrm{E}-04$ & $7,560 \mathrm{E}-03$ & $1,068 \mathrm{E}-02$ & $1,258 \mathrm{E}-07$ \\
\hline 37 & 0,012 & $5,130 \mathrm{E}-04$ & $9,928 \mathrm{E}-05$ & $0,000 \mathrm{E}+00$ & $1,418 \mathrm{E}-02$ & $4,519 \mathrm{E}-10$ \\
\hline 38 & 0,117 & $1,561 \mathrm{E}-03$ & $3,167 \mathrm{E}-04$ & $2,466 \mathrm{E}-03$ & $2,053 \mathrm{E}-02$ & $0,000 \mathrm{E}+00$ \\
\hline 39 & 0,599 & $3,567 \mathrm{E}-02$ & $7,159 \mathrm{E}-03$ & $9,635 \mathrm{E}-02$ & $3,721 \mathrm{E}-02$ & $3,478 \mathrm{E}-04$ \\
\hline 40 & 0,620 & $7,247 \mathrm{E}-03$ & $1,395 \mathrm{E}-03$ & $1,905 \mathrm{E}-02$ & $1,742 \mathrm{E}-01$ & $1,205 \mathrm{E}-04$ \\
\hline 41 & 0,620 & $7,449 \mathrm{E}-02$ & $1,753 \mathrm{E}-02$ & $7,745 \mathrm{E}-02$ & $1,019 \mathrm{E}-01$ & $1,168 \mathrm{E}-02$ \\
\hline 42 & 0,214 & $1,820 \mathrm{E}-02$ & $2,223 \mathrm{E}-02$ & $1,052 \mathrm{E}-01$ & $8,778 \mathrm{E}-02$ & $8,947 \mathrm{E}-12$ \\
\hline 43 & 0,231 & $8,493 \mathrm{E}-04$ & $1,720 \mathrm{E}-04$ & $9,854 \mathrm{E}-03$ & $5,005 \mathrm{E}-03$ & $3,032 \mathrm{E}-07$ \\
\hline 44 & 0,259 & $9,722 \mathrm{E}-04$ & $1,880 \mathrm{E}-04$ & $1,652 \mathrm{E}-02$ & $6,749 \mathrm{E}-03$ & $4,008 \mathrm{E}-07$ \\
\hline 45 & 0,765 & $4,518 \mathrm{E}-01$ & $1,252 \mathrm{E}-01$ & $3,012 \mathrm{E}-01$ & $2,346 \mathrm{E}-01$ & $3,487 \mathrm{E}-01$ \\
\hline 46 & 0,546 & $1,125 \mathrm{E}-01$ & $3,531 \mathrm{E}-02$ & $1,522 \mathrm{E}-01$ & $5,433 \mathrm{E}-02$ & $1,616 \mathrm{E}-03$ \\
\hline 47 & 0,453 & $6,873 \mathrm{E}-03$ & $1,331 \mathrm{E}-03$ & $7,949 \mathrm{E}-02$ & $2,275 \mathrm{E}-02$ & $5,147 \mathrm{E}-06$ \\
\hline
\end{tabular}

Tabla 11.6: Valores normalizados de los nodos (entre 0 y 1) para cada métrica de conectividad ecológica en Río Ratones. Fuente: Elaboración propia. 


\subsection{VALORES NORMALIZADOS DE LOS NODOS (ENTRE 0 Y 1) PARA CADA MÉTRICA DE CONECTIVIDAD ECOLÓGICA EN ITACORUBI}

\begin{tabular}{|c|c|c|c|c|c|c|}
\hline Nodo & $\mathbf{F}$ & AWF & PC & IP & OP & MC \\
\hline 1 & 0,561 & $7,407 \mathrm{E}-01$ & $6,915 \mathrm{E}-02$ & $2,474 \mathrm{E}-01$ & $3,971 \mathrm{E}-01$ & $1,000 \mathrm{E}+00$ \\
\hline 2 & 0,019 & $1,940 \mathrm{E}-03$ & $6,065 \mathrm{E}-05$ & $8,684 \mathrm{E}-03$ & $5,133 \mathrm{E}-04$ & $4,934 \mathrm{E}-06$ \\
\hline 3 & 0,004 & $2,276 \mathrm{E}-04$ & $3,459 \mathrm{E}-04$ & $1,487 \mathrm{E}-02$ & $1,522 \mathrm{E}-02$ & $1,132 \mathrm{E}-10$ \\
\hline 4 & 0,004 & $1,889 \mathrm{E}-03$ & $1,007 \mathrm{E}-03$ & $2,711 \mathrm{E}-02$ & $2,757 \mathrm{E}-02$ & $2,568 \mathrm{E}-06$ \\
\hline 5 & 0,259 & $1,671 \mathrm{E}-02$ & $5,219 \mathrm{E}-04$ & $1,432 \mathrm{E}-02$ & $5,246 \mathrm{E}-02$ & $5,343 \mathrm{E}-04$ \\
\hline 6 & 0,000 & $2,958 \mathrm{E}-04$ & $2,905 \mathrm{E}-05$ & $3,133 \mathrm{E}-03$ & $1,744 \mathrm{E}-03$ & $1,080 \mathrm{E}-07$ \\
\hline 7 & 0,017 & $6,740 \mathrm{E}-06$ & $8,176 \mathrm{E}-06$ & $1,185 \mathrm{E}-03$ & $5,510 \mathrm{E}-04$ & $5,719 \mathrm{E}-24$ \\
\hline 8 & 0,335 & $1,088 \mathrm{E}-03$ & $8,576 \mathrm{E}-05$ & $6,684 \mathrm{E}-03$ & $8,134 \mathrm{E}-03$ & $3,385 \mathrm{E}-26$ \\
\hline 9 & 0,328 & $1,039 \mathrm{E}-03$ & $4,241 \mathrm{E}-05$ & $3,321 \mathrm{E}-03$ & $4,599 \mathrm{E}-03$ & $9,031 \mathrm{E}-26$ \\
\hline 10 & 0,860 & $5,656 \mathrm{E}-04$ & $1,986 \mathrm{E}-05$ & $3,000 \mathrm{E}-03$ & $3,916 \mathrm{E}-03$ & $7,668 \mathrm{E}-20$ \\
\hline 11 & 1,000 & $5,644 \mathrm{E}-04$ & $1,497 \mathrm{E}-05$ & $2,597 \mathrm{E}-03$ & $3,030 \mathrm{E}-03$ & $7,027 \mathrm{E}-20$ \\
\hline 12 & 0,664 & $3,368 \mathrm{E}-04$ & $7,406 \mathrm{E}-06$ & $1,411 \mathrm{E}-03$ & $1,370 \mathrm{E}-03$ & $1,591 \mathrm{E}-20$ \\
\hline 13 & 0,461 & $1,636 \mathrm{E}-04$ & $0,000 \mathrm{E}+00$ & $0,000 \mathrm{E}+00$ & $0,000 \mathrm{E}+00$ & $2,865 \mathrm{E}-19$ \\
\hline 14 & 0,002 & $1,073 \mathrm{E}-03$ & $5,705 \mathrm{E}-05$ & $5,395 \mathrm{E}-03$ & $2,134 \mathrm{E}-03$ & $1,138 \mathrm{E}-06$ \\
\hline 15 & 0,003 & $0,000 \mathrm{E}+00$ & $2,399 \mathrm{E}-04$ & $1,207 \mathrm{E}-02$ & $1,225 \mathrm{E}-02$ & $0,000 \mathrm{E}+00$ \\
\hline 16 & 0,508 & $7,272 \mathrm{E}-01$ & $2,939 \mathrm{E}-02$ & $1,367 \mathrm{E}-01$ & $2,134 \mathrm{E}-01$ & $9,964 \mathrm{E}-01$ \\
\hline 17 & 0,065 & $4,004 \mathrm{E}-01$ & $1,916 \mathrm{E}-02$ & $1,445 \mathrm{E}-01$ & $8,685 \mathrm{E}-02$ & $2,117 \mathrm{E}-01$ \\
\hline 18 & 0,061 & $1,000 \mathrm{E}+00$ & $1,000 \mathrm{E}+00$ & $1,000 \mathrm{E}+00$ & $1,000 \mathrm{E}+00$ & $6,925 \mathrm{E}-01$ \\
\hline 19 & 0,002 & $7,090 \mathrm{E}-04$ & $2,626 \mathrm{E}-04$ & $1,208 \mathrm{E}-02$ & $1,296 \mathrm{E}-02$ & $4,418 \mathrm{E}-07$ \\
\hline 20 & 0,011 & $6,063 \mathrm{E}-01$ & $6,600 \mathrm{E}-01$ & $7,579 \mathrm{E}-01$ & $8,097 \mathrm{E}-01$ & $4,786 \mathrm{E}-01$ \\
\hline
\end{tabular}

Tabla 11.7: Valores normalizados de los nodos (entre 0 y 1 ) para cada métrica de conectividad ecológica en itacorubi. Fuente: Elaboración propia. 


\subsection{PROMEDIOS DE LOS VALORES NORMALIZADOS POR NODO}

\begin{tabular}{|c|c|c|c|c|c|}
\hline Nodo & Río Ratones & Nodo & Río Ratones & Nodo & Itacorubi \\
\hline 1 & 0,102 & 26 & 0,020 & 1 & 0,503 \\
\hline 2 & 0,047 & 27 & 0,037 & 2 & 0,005 \\
\hline 3 & 0,035 & 28 & 0,919 & 3 & 0,006 \\
\hline 4 & 0,012 & 29 & 0,526 & 4 & 0,010 \\
\hline 5 & 0,011 & 30 & 0,003 & 5 & 0,057 \\
\hline 6 & 0,108 & $31 a$ & 0,350 & 6 & 0,001 \\
\hline 7 & 0,088 & $31 b$ & 0,298 & 7 & 0,003 \\
\hline 8 & 0,086 & $31 c$ & 0,554 & 8 & 0,058 \\
\hline 9 & 0,034 & 32 & 0,179 & 9 & 0,056 \\
\hline 10 & 0,051 & 33 & 0,128 & 10 & 0,145 \\
\hline 11 & 0,128 & 34 & 0,033 & 11 & 0,168 \\
\hline 12 & 0,026 & 35 & 0,051 & 12 & 0,111 \\
\hline 13 & 0,013 & 36 & 0,011 & 13 & 0,077 \\
\hline 14 & 0,001 & 37 & 0,005 & 14 & 0,002 \\
\hline 15 & 0,070 & 38 & 0,024 & 15 & 0,005 \\
\hline 16 & 0,002 & 39 & 0,129 & 16 & 0,435 \\
\hline 17 & 0,008 & 40 & 0,137 & 17 & 0,155 \\
\hline 18 & 0,042 & 41 & 0,151 & 18 & 0,792 \\
\hline 19 & 0,018 & 42 & 0,075 & 19 & 0,005 \\
\hline 20 & 0,044 & 43 & 0,041 & 20 & 0,554 \\
\hline 21 & 0,067 & 44 & 0,047 & & \\
\hline 22 & 0,111 & 45 & 0,371 & & \\
\hline 23 & 0,019 & 46 & 0,150 & & \\
\hline 24 & 0,105 & 47 & 0,094 & & \\
\hline 25 & 0,059 & & & & \\
\hline
\end{tabular}

Tabla 11.8: Promedios de los valores normalizados por nodo. Fuente: Elaboración propia. 
11.10 VALORES NORMALIZADOS (ENTRE 0 Y 1) DE LOS PROMEDIOS POR NODO

\begin{tabular}{|c|c|c|c|c|c|}
\hline Nodo & Río Ratones & Nodo & Río Ratones & Nodo & Itacorubi \\
\hline 1 & 0,109 & 26 & 0,020 & 1 & 0,634 \\
\hline 2 & 0,050 & 27 & 0,039 & 2 & 0,005 \\
\hline 3 & 0,037 & 28 & 1,000 & 3 & 0,006 \\
\hline 4 & 0,012 & 29 & 0,572 & 4 & 0,012 \\
\hline 5 & 0,011 & 30 & 0,002 & 5 & 0,071 \\
\hline 6 & 0,116 & $31 a$ & 0,380 & 6 & 0,000 \\
\hline 7 & 0,094 & $31 b$ & 0,323 & 7 & 0,003 \\
\hline 8 & 0,092 & $31 c$ & 0,602 & 8 & 0,073 \\
\hline 9 & 0,035 & 32 & 0,194 & 9 & 0,070 \\
\hline 10 & 0,054 & 33 & 0,138 & 10 & 0,182 \\
\hline 11 & 0,139 & 34 & 0,034 & 11 & 0,211 \\
\hline 12 & 0,027 & 35 & 0,054 & 12 & 0,139 \\
\hline 13 & 0,013 & 36 & 0,011 & 13 & 0,096 \\
\hline 14 & 0,000 & 37 & 0,004 & 14 & 0,001 \\
\hline 15 & 0,075 & 38 & 0,024 & 15 & 0,005 \\
\hline 16 & 0,001 & 39 & 0,139 & 16 & 0,549 \\
\hline 17 & 0,007 & 40 & 0,148 & 17 & 0,194 \\
\hline 18 & 0,044 & 41 & 0,163 & 18 & 1,000 \\
\hline 19 & 0,018 & 42 & 0,080 & 19 & 0,005 \\
\hline 20 & 0,047 & 43 & 0,043 & 20 & 0,699 \\
\hline 21 & 0,072 & 44 & 0,050 & & \\
\hline 22 & 0,119 & 45 & 0,403 & & \\
\hline 23 & 0,019 & 46 & 0,162 & & \\
\hline 24 & 0,113 & 47 & 0,101 & & \\
\hline 25 & 0,063 & & & & \\
\hline
\end{tabular}

Tabla 11.9: Valores normalizados (entre 0 y 1 ) de los promedios por nodo. Fuente: Elaboración propia. 


\subsection{1 ÁREAS DE PROTECCIÓN AMBIENTAL POR NODO (MÁS CRÍTICOS) DE RÍO RATONES}

\begin{tabular}{|c|c|c|c|c|c|}
\hline Nodo & Protección ambiental & Área $\mathbf{m}^{2}$ & Nodo & Protección ambiental & Área $\mathbf{m}^{2}$ \\
\hline 1 & Protegido & $405.065,65$ & 21 & Parcialmente protegido & 4,57 \\
\hline 1 & Sin protección & $16.523,18$ & 22 & Sin protección & $95.240,14$ \\
\hline 1 & Parcialmente protegido & $333.126,82$ & 23 & Protegido & $11.077,13$ \\
\hline 2 & Protegido & $1.155 .698,74$ & 23 & Parcialmente protegido & $79.299,55$ \\
\hline 2 & Sin protección & $162.153,97$ & 24 & Parcialmente protegido & $38.314,62$ \\
\hline 2 & Parcialmente protegido & $644.308,95$ & 25 & Protegido & $239.370,98$ \\
\hline 3 & Protegido & $241.911,02$ & 25 & Sin protección & $1.418,56$ \\
\hline 3 & Sin protección & $74.003,89$ & 25 & Parcialmente protegido & $97.029,37$ \\
\hline 3 & Parcialmente protegido & $444.947,91$ & 26 & Parcialmente protegido & $75.549,39$ \\
\hline 4 & Sin protección & $167.996,00$ & 27 & Parcialmente protegido & $490.124,32$ \\
\hline 5 & Sin protección & $92.842,31$ & 30 & Protegido & $69.613,54$ \\
\hline 6 & Protegido & $147.525,25$ & 30 & Parcialmente protegido & $34.304,55$ \\
\hline 6 & Parcialmente protegido & $50.915,63$ & 30 & Sin protección & $16.292,67$ \\
\hline 6 & Sin protección & $48.261,09$ & 32 & Parcialmente protegido & $16.672,53$ \\
\hline 7 & Protegido & $7.569,57$ & 32 & Sin protección & $12.476,44$ \\
\hline 7 & Parcialmente protegido & $26.559,74$ & 33 & Parcialmente protegido & $47.660,62$ \\
\hline 7 & Sin protección & $36.214,85$ & 33 & Sin protección & $19.911,73$ \\
\hline 8 & Sin protección & $249.126,80$ & 34 & Sin protección & $153.296,80$ \\
\hline 9 & Parcialmente protegido & $1.157,33$ & 35 & Sin protección & $193.573,30$ \\
\hline 9 & Sin protección & $119.624,70$ & 36 & Sin protección & $195.900,92$ \\
\hline 10 & Parcialmente protegido & $3.003,77$ & 37 & Sin protección & 667,91 \\
\hline 10 & Sin protección & $182.498,96$ & 37 & Parcialmente protegido & $30.406,01$ \\
\hline 11 & Sin protección & $37.390,31$ & 38 & Protegido & 325,30 \\
\hline 12 & Parcialmente protegido & $231.302,43$ & 38 & Sin protección & $22.967,36$ \\
\hline 13 & Parcialmente protegido & $166.760,79$ & 38 & Parcialmente protegido & $43.442,58$ \\
\hline 14 & Protegido & $4.539,68$ & 39 & Sin protección & $256.198,80$ \\
\hline 14 & Sin protección & $98.843,24$ & 40 & Parcialmente protegido & $31.563,57$ \\
\hline 14 & Parcialmente protegido & $22.002,80$ & 41 & Protegido & $734.110,95$ \\
\hline 15 & Protegido & $5.952,55$ & 41 & Parcialmente protegido & $81.942,76$ \\
\hline 15 & Parcialmente protegido & $160.876,27$ & 41 & Sin protección & $22.279,82$ \\
\hline 16 & Sin protección & $29.210,96$ & 41 & Parcialmente protegido & 31,81 \\
\hline 17 & Parcialmente protegido & $141.452,17$ & 42 & Protegido & 295,77 \\
\hline 17 & Sin protección & $60.700,42$ & 42 & Sin protección & $2.028 .413,75$ \\
\hline 18 & Parcialmente protegido & $79.192,77$ & 43 & Sin protección & $52.247,06$ \\
\hline 19 & Parcialmente protegido & $69.332,57$ & 44 & Sin protección & $32.566,60$ \\
\hline 19 & Sin protección & $6.394,94$ & 46 & Sin protección & $380.848,78$ \\
\hline 20 & Protegido & $36.409,05$ & 46 & Protegido & $78.154,54$ \\
\hline
\end{tabular}

Continua... 
PARTE V. Capítulo 11. ANEXOS

\begin{tabular}{|c|c|c|c|c|c|}
\hline Nodo & Protección ambiental & Área $\mathrm{m}^{2}$ & Nodo & Protección ambiental & Área $\mathrm{m}^{2}$ \\
\hline 20 & Parcialmente protegido & $229.685,09$ & 46 & Parcialmente protegido & $166.681,19$ \\
\hline 21 & Protegido & $22.530,76$ & 47 & Sin protección & $51.419,79$ \\
\hline
\end{tabular}

Tabla 11.10: Áreas de protección ambiental por nodo (más críticos) de Río Ratones. Fuente: Elaboración propia. 


\subsection{2 ÁREAS DE PROTECCIÓN AMBIENTAL POR NODO (MÁS CRÍTICOS) DE} ITACORUBI

\begin{tabular}{|c|l|c|}
\hline Nodo & Protección ambiental & Área $\mathbf{~}^{2}$ \\
\hline 2 & Sin Protección & $20.127,58$ \\
\hline 3 & Sin Protección & $125.643,55$ \\
\hline 4 & Parcialmente Protegido & $199.812,60$ \\
\hline 4 & Sin Protección & $8.841,35$ \\
\hline 5 & Parcialmente Protegido & $19.499,04$ \\
\hline 5 & Sin Protección & $7.377,36$ \\
\hline 6 & Parcialmente Protegido & $24.656,80$ \\
\hline 6 & Sin Protección & $10.955,02$ \\
\hline 7 & Sin Protección & $26.889,73$ \\
\hline 8 & Parcialmente Protegido & $17.262,02$ \\
\hline 8 & Sin Protección & $35.090,15$ \\
\hline 9 & Sin Protección & $28.907,91$ \\
\hline 10 & Sin Protección & $21.733,44$ \\
\hline 11 & Parcialmente Protegido & $7.378,05$ \\
\hline 11 & Sin Protección & $8.486,10$ \\
\hline 12 & Sin Protección & $15.030,04$ \\
\hline 13 & Protegido & $385.111,97$ \\
\hline 13 & Parcialmente Protegido & $81.181,29$ \\
\hline 13 & Sin Protección & $144.833,84$ \\
\hline 14 & Parcialmente Protegido & $25.413,65$ \\
\hline 14 & Sin Protección & $12.740,05$ \\
\hline 15 & Protegido & $5.872,01$ \\
\hline 15 & Parcialmente Protegido & $39.669,31$ \\
\hline 15 & Sin Protección & $60.666,06$ \\
\hline 17 & Protegido & $133.505,59$ \\
\hline 17 & Parcialmente Protegido & $210.301,20$ \\
\hline 17 & Sin Protección & $214.691,51$ \\
\hline 19 & Protegido & $3.014,22$ \\
\hline 19 & Parcialmente Protegido & $3 ., 57$ \\
\hline 19 & Sin Protección & \\
\hline & & \\
\hline
\end{tabular}

Tabla 11.11: Áreas de protección ambiental por nodo (más críticos) de Itacorubi. Fuente: Elaboración propia. 